\title{
On Macedonian and Thracian Greek Wines
}

\author{
Th. Markopoulos
}

Ministry of Rural Development and Food of the Hellenic Republic

Received 19 May 2020; Accepted 7 July 2020

\begin{abstract}
Wine is a special product with a long tradition but it is also strongly influenced by the local soil and climatic conditions of the area where the vineyards are grown, yielding the grapes from which wine is produced.Existing Greek and EU legislation has established a framework of analysis, applied on a sampling basis, with the primary aim of protecting both the consumer and the producers, by safeguarding the wine production process in accordance with scientific principles and current legislation. In the present monograph the available data from analyses carried out on samples from wines produced in Eastern Macedonia and Thrace (located in northern Greece) have been recorded, codified, quoted and processed by the relevant competent authorities of the state, using the sampling procedure provided. The work first analyzes the results produced by the analyses, in order to draw the initial conclusions. The results are then processed using an application for geographical separation, co-variance analysis for the dependent variables, and the creation of time series diagrams. The last two statistical analyses are conducted by exploiting the available climatic parameters of the area. This work has shown the high quality of the wines in the area, the general absence of problems in the wines it produces, and the respect paid to the existing legislation related to winemaking and the use of Protected Geographical Indication (PGI) provisions, since the vast majority of wines produced in the area fall into this category. The statistical analysis of the three methods used yielded indications concerning the separation of wines produced in individual areas, as well as the correlation of wine parameters with climate parameters, and the boundaries of the climatic data where the wine parameters are maximized or minimized. The results are of particular importance in the design of new vineyard installations and wineries, as well as for new wines on the one hand, and the high importance for assessing the impact of the ongoing global changes in climatic conditions on the other. At the same time, these analyses form the basis for further scientific research in order to formulate a modern, efficient, sustainable and developmental policy that includes planning for the development of viticulture and winemaking in the area, and by extension, in any other viticultural area.
\end{abstract}

Keywords: quality control, wine, wine analysis data, climate factors, Macedonia, Thrace, geographic indications, geographical discrimination, alcoholic strength, total acidity, volatile acidity, residual sugars

\section{Introduction}

Wine production in northern Greece, in addition to being an important branch of the modern agricultural production process and the local economy, at the same time comprises a tradition lost in the depths of the centuries and millennia before Christ's birth. Of exceptional historical, scientific and cultural interest are the references preserved through sources such as the Homeric epics, as well as archaeological research. The ancient Greek poet Homer is mentioned, for example, in the production of some well-known wine varieties and high quality wine in the area of ancient Kikones at Maroneia in the present-day regional prefecture of Rodopi. The Philippi area in Kavala is said to have produced one of the most ancient wines in world history; according to an oral presentation of the Kavala-Thasos Antiquities Board, the oldest specimen of wine ever found was discovered in excavations, with an age of 6,200 years, in the prehistoric settlement known as "Dikili Tas", or "Megalo Lithari", located almost $2 \mathrm{~km}$ from the ancient city of Philippi. Following the efforts of scientists, the presence of tartaric acid, a fermentation product, along with traces of wine and charred grape pips, was certified in ceramic grape vessels found in a Neolithic house [1]. Certainly, the use and appeal of wine since antiquity has been explored and

*E-mail address: thamarkopoulos@yahoo.gr

ISSN: 1791-2377 @ 2020 School of Science, IHU. All rights reserved.

doi:10.25103/iestr.134.04 described both in ancient Athens and elsewhere [2]-[4], while it may also be worth mentioning here the characteristic expression of the ancient Romans - vino veritas: "in wine there is truth" [5].

Over the centuries and especially after the prevalence of phylloxera (Phylloxera vastatrix PV) in northern Greece in the early 20th century, viticulture and wine production suffered a severe blow. Vineyard cultivation in the areas where phylloxera had now become endemic was only possible with the use of American rootstocks, whose use, however, ensured grapevine cultivation from that point on. Moreover, at the same time, the use of local varieties traditionally cultivated and produced for centuries was in great decline, replaced some decades later with foreign (mainly French) varieties [6].

Today, cultivation in the area of vineyards for use in winemaking utilizes the area's soil and climate data and the context of the cultivation work provided by the vine growers. Like all crops, both viticulture and winemaking also operate under the framework of the Common Agricultural Policy (CAP) established by the European Union (EU), which is incorporated in both national and European legislation. This framework includes, inter alia, commitments in terms of cultivation practices, e.g. inputs, environmental and licensing legislation governing processing installations in particular wineries financing, community aid, and specifications which have to do with both the facilities used, as well as the 
specifications and categorization of the wines produced there. This framework is the same one used in this area as well as throughout Greece. Reference to specific regulatory guidelines will also be followed up in this work.

Overall, similarly to the entire agricultural production process, the production of wine grapes and wines also affects both the local economy and the development of the wider region [7]. It should not be overlooked here that policies to promote balanced growth can contribute to both the development of the food sector and sustainable economic growth in the long run [8]. In addition, the potential for involvement and exploitation of the wines produced in agrotourism and the wider touristic development comprise another point that provides a valuable advantage for the economic development of the individual regions and the wider region in general. People involved in wine production must actively engage and cooperate with stakeholders who represent consumers and marketers, in order to achieve the best results and to make a decisive contribution to the development of tourism [9]. Based on international experience, it is often found that the production of wine, starting from the field and finishing with the sale of the bottle to the consumer, constitutes an important production activity with a significant impact on the economy and general development at various stages. This finding is not limited to regions with a strong tradition steeped in centuries and millennia of winemaking, but also to other regions of the planet that are not characterized by such features [10]. It is important to note that, in today's times and in every region, significant efforts are made to meet high quality standards and legal requirements, and to assess the impact of wine production on tourism and the economy.

In the EU, under the provisions of the CAP, there were initially no restrictions in terms of the areas that any given producer could plant and cultivate. More than four decades ago, starting in 1978, restrictions concerning planting capacities were introduced for the first time, followed by the introduction of assistance grants for uprooting vineyards. Subsequently, Regulation (EC) No 1493/99 of 17 May 1999 laid down the context for reforms and commitments establishing the framework for the Wine and Vine Common Market Organization (CMO). Regulation (EC) No 479/2008 of 29 April 2008 concerning the same CMO provides for both support measures and regulatory measures concerning wine, as well as rules on trade with third countries. The purpose of this regulation was, inter alia, to preserve traditional and established policies concerning wine quality, and at the same time to formulate labeling rules, for the benefit of both producers and consumers.

This was followed by the adoption of Regulation (EC) No $606 / 2009$, with the view to "laying down certain detailed rules for the application of Regulation (EC) No 479/2008 regarding the categories of wine products, oenological practices and restrictions to which these are subject". Subsequently, with regard to quality control, on 29 February 2010, the Official Journal of the EU published the "List and description of the methods of analysis referred to in the first paragraph of Article 120 of Council Regulation (EC) No 1234/2007", which was published pursuant to Article 15 (2) of Commission Regulation (EC) No 606/2009 of 10 July 2009. Reference should also be made at this point to the earlier Commission Regulation (EC) No 2676/2009 "concerning the Regulation of Community methods of analysis which are applied to the wine sector", which has been amended during the last three decades as many times as has been deemed appropriate by the decisions of the competent community authorities.

In the context formulated by all the above, a host of analyses for the wines produced in Greece are carried out by the Greek public civil services, for the purposes of quality control, in order to ensure the level of quality of the wines being produced and marketed, and also to maintain a uniform and common framework governing wine production throughout the EU. Of course, the overall concept of the quality of wines cannot be exhausted solely on the basis of these regulatory guidelines and the context of the existing provisions governing quality control, without taking into account the rich and evolving scientific research in this field. The European guidelines, however, describe a clear minimum set of requirements based on Community legislation, which guarantees quality but also protects both producers and consumers from unfair competition.

This scientific study attempts to fill a gap in the scientific literature relative to the quality characteristics of wines produced in the areas of Eastern Macedonia and Thrace. Thus, through the presentation of the available results and their statistical processing and the correlation effort with the specific production area and the available climatic data, it includes a scientifically useful assessment, which can contribute to the further planning of the industry. In other words, it tends to answer the hypothesis: whether we want to promote the development of winemaking production, what specialized scientific data would we like to have available? More specifically, the purpose of this study is described in paragraph 2.2 with the homonymous title. In the same paragraph, it is stated that this is the first time that the specific data have been scientifically researched so that the study acquires novelty characteristics regarding the region and more broadly for the development of the wine industry.

\section{Literature review}

"Wine is predominantly an aesthetic product exactly like art" [11]. Besides this, in wine markets, the key processes are transparent in order to facilitate drawing clear conclusions, in all cases, concerning the wine quality [12]. Another view characteristically states that "Wine production is both art and science, a blend of individual creativity and innovative technology" [13]. The same scientific text adds that wine production is also a business, and as such, business inc ludes concepts such as prices, exports, markets, consumer requirements, taxation, and a still larger number of other economic factors which are also involved in the sector. While success fundamentally lies in production meeting consumer expectations, high added value, as well as tourist development, the benefits ultimately lie within the whole wine production region. From another scientific source entitled "The wine and the vine" [14], wine is described as a special expression of the interaction of human beings with their environment, which, besides the symbolisms it contains, is, as also pointed out here, at the same time a product of high significance in economic terms for the regions where it is produced.

In addition, as stated on its website by the tertiary cooperative organization dealing with wine and vine products in Greece, under the title Hellenic Central Cooperative Union of Wine and Vine Products (KEOSOE): "It is not widely known that the wine sector in the European Union, in terms of primary production (vine) as well as processing (wine), is governed by the most complex legislation of all agricultural 
products"[15]. It is not possible to oppose this view, since the concept of wine is linked aesthetically, economically and enterprisingly, together with the EU's complex legislative framework. Wine, however, is a product that strongly incorporates the local soil and climatic elements of the region, which also transfers its reputation to the wines produced there, which are eventually marketed under the name of the region [13]. This is how the resonance of the particular cultural and historical character of the region is transferred to the wine made in that region. While the classic definition, which states that wine is the beverage resulting from the alcoholic fermentation of grape juice under appropriate procedures [2], is not disputed, it is nevertheless certain that wine is ultimately something wider and something much more complex than that. The quality and the particular characteristics of a specific wine variety are influenced by the climatic and soil elements that characterize each region [16].

As the wine market evolves under present-day conditions influenced by globalization, it should be highlighted that wine quality is not just a competitive advantage in the context of competition, but a mandatory condition to the survival of any winery [17]. Another expression of this idea states that the term "quality" must relate to the growing consumer demand for a differentiated taste of the product, with the everincreasing regulatory pressure to protect the environment[18].

In the German market, two concepts have emerged, which exist in parallel, concerning wine quality. Thus, the term "quality in the glass" is used, which is both the official approach and the concept of "terroir" and is promoted by the private association of quality winemakers, known in German as "Verbant Deutscher Pradikatsweinguter". Research published by the Max Planck Institute indicates that the second system included in the term "terroir" is more powerful in explaining the formation of market price levels for wine [12].

The reputation of the wines and the impact they have on the market and among consumers is approached from two opposing aspects: the use of geographical indications and collective reputation, which prevails in the so-called Old World or old countries (mainly Europe), and the individual reputation of branded wines, which prevails in the New World or new countries. It is obvious that these two divergent approaches are the result of different conditions and historical evolution, although it does not exclude the idea that for some wines, both approaches may coexist [19]. There are also differences between new and old countries in terms of the production conditions of the grapes from which the wine is produced; for example, in the new countries, the vineyards are larger in expanse than in Europe. In Italy, small vineyards coexist together with larger areas [20] owned by wine businesses that operate with an industrial character. In the example of Italy, Protected Designation Origin (PDO) and Protected Geographical Indication (PGI) wines constitute the majority of the wines produced.

In France, with its vast winemaking tradition, it should be noted that the main challenge is to exploit all the parameters involved, in order to enhance the competitiveness of production in the context of modern market conditions [19]. Likewise, it should also be emphasized that competition from the New World, the changing dynamics of the markets and technological developments have called into question the view that in traditional winemaking regions, such as Burgundy, the quality of the wine depends on the geographical indication of the production area, which encompasses both its culture and its history, and is not undermined by production taking place in new countries. It is now imperative that traditional areas should also adapt to the developments and gain the flexibility needed to survive [20].

The production process involved in producing wine in a winery, the development of which, together with the conditions of grape production, commonly defines the concept of quality, is a complex as well as sensitive process, with many effects. The process at the winery from the "Grape Harvesting" stage to the "Storage of the bottles" is illustrated in the diagram below in Fig. 1 [21]. This process contains many critical points and preventative measures, which we must be able to apply, as well as certain limits that must not be exceeded, and control measures that must be carried out. This process has been described in detail by Christaki and Tzia (2002).

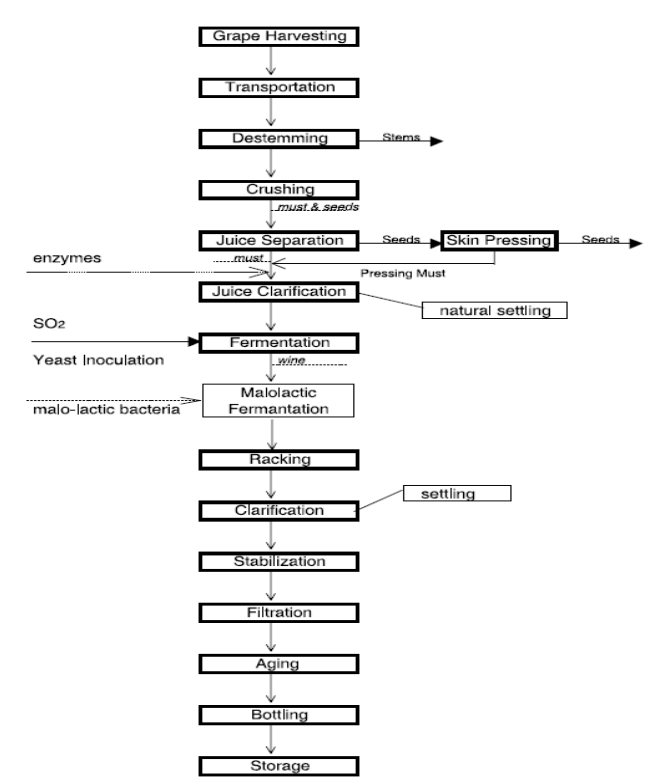

Fig. 1. Processes in the winery, from "Grape harvesting" to "Storage of the bottles" [21]

Implementation of Hazard Analysis and Critical Control Points (HACCP) in wineries is, in all respects, essential to ensure the successful and safe completion of the process, with the ultimate aim being the production of high quality, problem-free wine [22].

Of particular significance is a diagram developed earlier by other scientists [17], which includes all the factors related to the quality characteristics of the wine produced in relation to the materials used and the processes involved in the winery (Fig. 2).

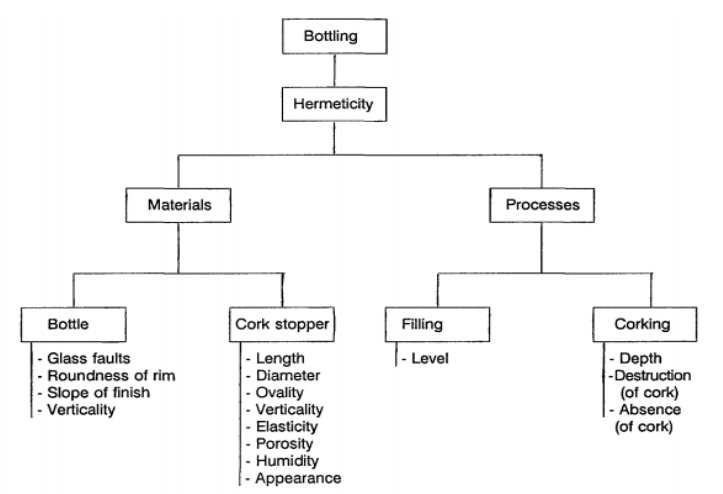

Fig. 2. Factors affecting the quality characteristics of wine in wineries [17]. 
The quality of the wine produced clearly affects exports and the final prices that the wine is sold at, but not in the same way in all markets, as shown by research conducted in Portugal [23]. On the other hand, in Japan, scientific research has shown that geographical indications for wines are positively evaluated and play an important role in the consumption of wines in that country [24]. The same finding has been concluded by other scientific studies, which typically state that consumers place significant value on geographical indications of origin, but this effect increases with increasing awareness and information and knowledge about these issues, with greater emphasis on the information provided by the private sector [25]. The EU has produced and implemented an entire framework for the protection of geographical indications [26].

In Australia, research investigated wine drinkers' perspectives on how quality is conceptualized; it was found that it is generally difficult to formulate a model capable of interpreting how consumers perceive and understand quality, and in particular if they share the same approaches that scientifically or technically shape it. Consumers can adopt subjective or objective contexts, some of which may be oriented towards more relative views, while others may be purely qualitative positions [27]. More generally, however, the preferential approach of consumers concerning wine and the concept of quality also has many subjective elements. Wine quality has been found to eventually include aspects that are difficult to interpret. Hence, as a concept, we realize that consumers approach wine according to their varying levels of knowledge. In practice, however, research conducted on wine quality offers traders the opportunity to approach quality as this is perceived by consumers [28].

In Greece, research has shown that consumers trust the PDO geographical indication (mainly consumers with higher education), with this confidence addressing either the legislation governing PDO wines, or the method with which they are produced. The same research has shown both the need to promote the wines of a region with a geographical indication, as well as the need to promote the region itself. An example of this is the geographical indication known as "Peza - Crete", which seems to concentrate a significantly high level of preference. This conclusion is also consistent with the approach that focuses on highlighting wine tourism and other relevant local activities [29].

The willingness of Greek wine consumers to pay more for wine with a geographical indication varies depending on social and demographic characteristics. It has been found that consumers are willing to pay twice the price of a standard bottle of table wine if the alternative solution provides a guarantee as to the place of origin of the wine. Their decision is found to depend on their educational level [30]. Other research has shown that winemakers are always willing to try to build stronger relationships with their customers. Thus, the winemakers' side emphasizes certain features of the wine in an attempt to make consumers faithful to that particular wine, and thereby increase the likelihood of the same wine being marketed again, taking advantage of the features which it has highlighted and which are on the label, e.g. variety, winemaker and wine category. Consistency, when linked to quality, can encourage the above efforts, and may provide winemakers with the potential to create better wines that will attract more consumers, and thus drive a desired increase in market share [31].

Concerning Greek winemaking, other scientific research has documented that while the quality of Greek wines is high, that alone is not enough, as a country, to achieve high export levels. An effective strategy or an integrated policy is needed as well as the identification of efforts made in the direction of maintaining Greek varieties, where there is a reasonably comparative advantage that does not exist in the so-called international varieties produced in the New World at low prices and in large quantities [32]. Twenty years ago, the wine market was regarded at the time as highly fragmented. Using quality attributes and their promotion may be somewhat useful in creating niche markets and promoting rural locations as geographical indications [33]. Applying a quality system to a winery can help improve its operation and solve problems in the production arena [34].

Research conducted in Greece, related to the applied or transparent strategies used to promote wines, has found, among other things that wine producers are trying to capitalize on their long tradition. Moreover, the designs of the labels that Greek winemakers usually prefer mainly use landscapes, with a white or off-white color for the label. In addition, the wording used (by the winemakers) for the names of the wines has no particular meaning, while many of the trademarks are associated with the vineyard's name, location or region. Finally, over $60 \%$ of the trademarks are aimed at both the young and the old, regardless of income and educational background, without any specialization [35].

Furthermore, wine tourism in the wine-producing areas of the world has grown rapidly in recent years as travelers look for opportunities to try winery products at the cellar door. The key to the continued growth and success of these businesses lies in satisfying customer expectations in terms of services and products [36].

In general, according to the rules in force, winemakers are classified into various categories ascribed by the wine markets, based on the decisions of wine guides [37] and some official classifications, while consumers are also classified into various categories, according to the quality of the wines that they buy.

In Greece, the PCA (Principal Component Analysis) analysis was applied [21], [38] in an effort to contribute to tackling the distortions concerning the geographical origin of the wine; this led to the classification of only Greek red wines, in terms of their geographical origin, into a very narrow set of wine groups, namely wines produced in the Aegean and Ionian islands, wines from northern Greece and wines from southern Greece. A similar effort of qualitative classification using the PCA method also took place in South Korea [39]. Furthermore, a method has been developed to classify wines according to variety and geographical origin using Nuclear Magnetic Resonance (NMR) - based metabolomics. This method allows making a distinction between wines from different wineries in the same wine-growing zone, and between different vineyards for wines of the same variety [40]. Medium infrared spectroscopy in combination with the appropriate software was used in an attempt to differentiate the Greek varieties. This method has shown that wines from different grape varieties can be differentiated between them [41].

Worldwide, wine quality is tested by experienced and trained tasters, who are often also assessed through specialized tests to check their ability to evaluate wine varieties [42], [43]. As far as the tasters are concerned, scientific work has shaped some preconditions concerning how they analyze and exploit the contributions they make in terms of wine evaluation [43], [44]. Apart from these tests, the EU foresees a number of laboratory tests which are subject to a series of laboratory controls, all conducted by sampling. Through analytical testing, quality control programs are 
foreseen in many countries, the EU and US included, both for the protection of consumers from unintentional errors during production, and to reduce cases of fraudulent practices [45].

More specifically, in cases of "significant" wines in terms of the economy of the regions producing them, models have been developed that process the wine parameters, which are determined by analyses in order to make contributions in the tasting sessions performed [46]. Other scientific work has attempted to correlate the wine parameters that are identified in the analyses in order to make further contributions towards the continued study of these variables, as well as to advance knowledge about their contribution in assessing the quality characteristics of wine [47], [48]. One approach in assessing wine quality is to utilize easily identifiable elements in the vine rails by introducing them into a Fuzzy Multicriteria Decision Making - FMCDM system [49].

The analyses and the determination of the wine parameters, in the context of determining its qualitative characteristics, is nothing new, as it has already been reported that a laboratory specialized in wine analyses had already been operating since the $19^{\text {th }}$ century [50] under the guidance of Charles Remigius Fresenius (1818-1897), while in 1882, the first guide was published by Eugen Borgmann which included methods of analysis for wine. Two centuries later, research focuses on the approach of satisfying consumer demands, which include quality assurance and food security requirements. Thus, the traceability of wine is chosen as one of the most appropriate scientific approaches to investigate the origin of wine [51].

As previously stated, the EU has already established a framework over many years for testing wine quality and carrying out analyses on wine in the context of quality control, following a planned sampling procedure by the competent public services. The wine parameters identified in the quality control analyses have been exploited by scientists in an attempt to classify wines into qualitative categories using statistical science, thus yielding a classification system comprising six categories for red wines and seven categories for white wines [52]. The same wine parameters have been exploited by scientists to evaluate wine quality using Information Technology (IT) and other related electronic applications [53], as has been done in other food categories [54]. A similar effort has been made using algorithms [55][57], utilizing the wine parameters determined either by the analyses provided by European legislation for the purpose of assessing wine quality, or using other measurements.

Another approach to wine quality was created by scientists in a university study in China, which has no tradition in this field. This study concluded that for red wines four parameters were found (volatile acidity, total sulfur dioxide, sulfates and alcohol strength) which are sufficient to be used as indicators for high quality wine, whilst for white wines they identified other four parameters (total acidity, volatile acidity, residual sugar, alcohol sulfates), which are sufficient for the same reason [58]. It should be noted here that in published papers by a Greek university, China is listed as a target for exporting Greek wines [59].

Other scientists have attempted to correlate the various wine parameters with the price of the bottle, having achieved satisfactory results [60] by creating, for this purpose, a " 100 point scale" to check the quality, and introducing the concept of "wineinformatics". While the correlation between the quality of wine and the price the consumer intends to pay for it is a subject that has occupied much scientific research, the dominant view concerning this subject is that the consumer intends to pay a higher price on the basis of quality factors, as well as the reputation of the wine and its place of production [61].

Overproduction of wines around the world, as noted by many researchers [62], makes the wine market more complex. In this context, research using data from the last twenty years has shown the existence of a moderate but statistically significant and partial correlation between wine prices and sensory quality ratings [63].

From the cultivation aspect, the view that better quality wines are produced from vineyards with a limited production capacity per hectare of vineyards is generally valid [64]. However, it is also scientifically upheld that this is not entirely valid to the same degree for all vineyards and for all varieties [65]. Other scientific studies report that the variation in the vigor of the stumps in the wines of wine-making vineyards, the production load per hectare, the vineyard soil and the topography of the vineyard affect the wine and its features, as these are determined [66]. More generally, all the kinds of cultivation work involved in the vineyard also affect the quality of the wines that are produced in it. For example, the height of the configuration of the fruiting zone in some varieties affects the quality of the production [67].

It has been found that the aroma of the wines produced, as determined qualitatively or by the determination of parameters from the analyses, such as for example volatile acidity, or as noted by wine tasters, is influenced by the conditions prevailing in the vineyards. From the point of view of vineyard location, soil type and seasonal weather are considered to be the most important variables, while in terms of crop care, sunlight, canopy management, water, nitrogen fertilizers and fungicide treatments are deemed important [68]. The complexity of the substances in the vine rail of wine-growing varieties in the vineyard, and the way in which these substances are formed [69] admittedly make it extremely difficult to monitor the effects of the aromatic nature of not just the grapes but also the wines, along the course of the journey they take that completes their formation.

Climatic factors affect the degree of ripening of the vine rails and can affect the quality of the wine, but this is not the case for all varieties to the same degree [70]. Wine quality has been scientifically linked to the climate conditions that prevail in the area where the vineyards are grown. Overall, the climate of each region determines the suitability of the area for the cultivation of different vine varieties, and therefore the type of wine that can be produced there, in order to produce high quality wines, as well as to support the sustainability of the wine industry [71]. Scientific research in different regions correlates climate data with the characteristics of the wines produced in the region [72], [73], [74]. Concerning the famous Bordeaux vineyards in France, the impact of the climate of each crop period has been studied for both the production quality and the economic results [75]. For the same region it was found, inter alia, that the sugar/acid ratio is also affected, but not to the same extent in each variety, and this causes different effects on the wine that is eventually produced [76]. Moreover, relationships between the environment and vine cultivation, as well as the environment and wine production, have also been investigated for many decades in the western US [77]. In Italy, scientific studies show an attempt to exploit freely available meteorological and climatic data on the Internet in order to draw conclusions about the quality of wine that is expected to be produced. Overall, it is shown that higher quality is achieved during the years with relatively high temperatures and limited rainfall [78], while the effect that the climate of each growing season has on the temporal evolution of the phenological stages 
seems to affect the wine that is eventually produced. Indeed, climate change, through the changes that it can cause in these stages, affects the quality of wines [79]. For the same country, the same is confirmed by other scientific studies, which correlate not only the climate phenomena in the vineyards but also the developments of the general meteorological and climate phenomena, such as the spring jet stream over the Atlantic Ocean [80].

In Greece, non-irrigated vineyards have shown that the lack of water in the more arid cultivation seasons has led to an increase in sugars and the breakdown of malic acid. Moreover, the relative absence of water had beneficial effects on the concentration of anthocyanins, and also caused an increase in the levels of the aromatic constituents of grapes. Finally, it was also found that these grapes were preferred in taste tests [81].

Scientific results describe the possibility of predicting future vineyard yields using climate data from vineyards [82], while other scientists have proposed a study to reduce the vulnerability of the wine industry [83].

In Hungary, the correlation was proven between the quantity of grapes produced and the quality levels and climatic conditions of the region. It was thus confirmed that the most important factors are the sunshine hours in May, June, July \& August, together with the rainfall levels in September. For wine quality, the most important factors were found to be average temperature, rainfall and hours of sunshine in May and September, together with rainfall in July and hours of sunshine in August [84]. In another scientific study in California [85] using data from 1970 to 2004, the results showed that the climatic conditions of each cultivation year affect both the quality and the price of wine. However, this relationship is much stronger for prices than it is for quality ratings.

It is inevitable that, since the climatic conditions affect the wine which is produced in one area, then by extension, climate change, which has been evolving during the last decades, can and does affect, in its turn, the quality of the wine produced, modifying it to some extent [5]. As the climate changes, it becomes imperative, in terms of viticulture and winemaking, to explore and find ways to survive [86]. In France, the study of the harvesting conditions of the last four centuries (since 1600) has shown that the harvesting time has now been affected; indeed, the early harvest period takes place at higher temperatures, not because of the drought of a growing season, but because of the greenhouse effect. Thus, concerns are raised that climate change can further modify the climate and hence have consequences on viticulture and wine quality[87]. Furthermore, the change in the components of the vine rail, for example higher sugars, can affect the fermentation and chemical processes, and thus ultimately affect the wine produced [88]. It should be noted that the relationship between climate parameters and production has been monitored over many centuries in very numerous studies assessing their impact and the prices achieved for wine [89].

During the last fifty years of the last century, from 1950 to 2000 , the analysis of climate data showed that temperature had a steadily rising trend while fluctuations between years decreased. During the same period, the quality levels achieved in the wine that was produced improved. But after this, it is not certain that the continuation of the evolution of climate change will continue to affect all regions and all varieties uniformly and to the same extent, and thus a redistribution of wine-producing regions is likely to occur worldwide [90]. These estimations are of particular relevance as scientific research demonstrates the link between climate change and the climate that periodically prevails in Europe [91].

For the western US, and in particular the Napa Valley, the scientific view has been expressed that the meteorological phenomena occurring in the Pacific Ocean have an impact on the climate, and therefore on the vine and wine produced, and it is believed that the effects caused by the climate can affect all of the Denomination of Origin wines in that particular region [92]. In Europe, the rise in temperature in the context of climate change has been scientifically documented as having an impact on wine quality by altering the water balance in the wine-growing areas and shifting the harvest to an earlier time period, with whatever alterations to the chemical composition of the grape this may give rise to [93]. There is evidence of the quantitative effect of temperature on sugars and acids, and the aromatic compounds of grapes and wine. The current study highlights the significant changes that the evolving climate change can bring about on viticulture [94].

For northern Europe, and in particular the Rhine Valley in Germany, a good correlation has been achieved between the quality ratings of the wine produced over the last 300 years (for which a classification system has been drawn up, with five categories) with the climatic data recorded at meteorological stations in England [95]. In the same study, it was argued that a rise in the average temperature by $1^{\circ} \mathrm{C}$ for the entire growing season would improve the quality of the Rhine wines. On the other hand, it is estimated that rising temperatures in Australia will have a negative impact on vinegrowing areas. The impact on quality, of course, varies, with more adverse effects in inland areas [96].

In SE Spain, in the years 1952 to 2006 , an increase in temperature of $1.3-2.2^{\circ} \mathrm{C}$ was observed, which generally led to higher wine quality in the years with the highest temperatures for daily ripening, as well as reduced production in the warmer years in general. Concerning the annual amount of rainfall, the trends were not very clear. However, it has been estimated that short-term increases of $1^{\circ} \mathrm{C}$ during the growing season may imply an increase in water requirements of $6-14 \%$ based on evapotranspiration calculations [97].

Pons et al (2017) suggest that appropriate measures should be adopted to mitigate the effects of climate change, such as the careful selection of harvest dates and the adoption of appropriate cultivation practices, such as limiting dilution and the management of the plants' nutrition, with sufficient nitrogen in order to secure the germination power of the stumps, so as to achieve the preservation of the aromatic potential of the grapes[98]. In addition, however, if climate change continues and reaches extreme levels, varieties will need to be monitored, in order to exploit those that are deemed more adaptable. A further issue concerns changes in rainfall patterns and their potential impact on the development of pathogenic factors, which can in turn influence the quality of the vine rails and the aromatic and taste characteristics of the wines as they age. Scientific research has proceeded by identifying a series of substances in the rails of winemaking grapes that shape the aroma of the wines produced. The challenge for the future is to develop detailed strategies for determining the taste of wine and its relation to consumer expectations [99].

\subsection{Area Description}

The Greek Ministry of Rural Development \& Food, which is responsible for carrying out the foreseen analyses in the context of quality control for the wine produced, implements this responsibility through its decentralized services, which 
are equipped with the relevant laboratory infrastructure and specialized staff, each known as the "Regional Center for Plant Protection, Quality \& Phytosanitary Control". There are eight such services in the country, located at: Piraeus, Patras, Nafplio, Heraklion, Ioannina, Volos, Thessaloniki and Kavala. According to the organogram of the Ministry, these decentralized services belong to the Directorate-General for Food, as it is named. The areas of competence of these services, for practical reasons, do not wholly identify with the country's regional divisions prefectures into administrative regions. In particular, the Kavala Regional Center for Plant Protection, Quality and Phytosanitary Control covers a jurisdictional area (Fig. 3), which includes the prefectures of Serres, Drama, Kavala, Xanthi, Rodopi and Evros, while the administrative division of the country (Law 3852/2010) stipulates that the prefecture of Serres belongs to the Region of Central Macedonia, whereas the other five prefectures constitute the Region of Eastern Macedonia-Thrace.

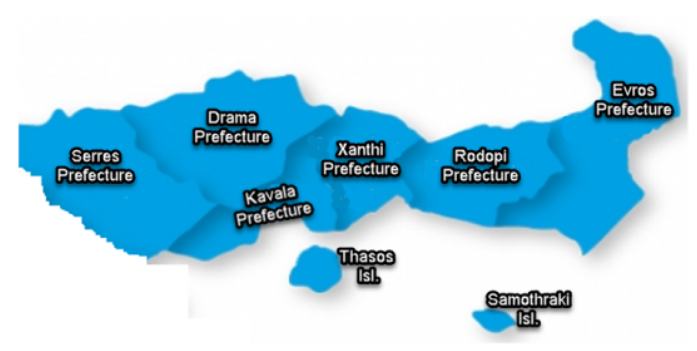

Fig. 3. The area of responsibility of the Regional Center of Plant Protection, Quality and Phytosanitary Control of Kavala, which constitutes the area being investigated in this study.

Concerning this area, it should be noted that the geographical position has been subject to decisive developmental disadvantages for quite a few decades, mainly due to its distance from the country's capital, Athens, but also because of its proximity to Turkey and Bulgaria. It is worth noting that for a long period of several decades, the borders constituted restrictive boundaries with limited to minimal communication between them. Today, and precisely in the last three decades, the area's acrimonious aspect has begun to diversify and has even become a comparative advantage, as Bulgaria is now a member of the EU, and relations with Turkey, despite the above-mentioned problems, have improved.

Important national and trans-European transport and energy networks (eg the Trans Adriatic Pipeline - TAP and the Hellenic Gas Transmission System Operator pipeline DESFA) pass through this area. Also, thousands of citizens and visitors are crossing the border here, together with large quantities of goods and products. In addition, this area is home to major entrance passageways to the area, such as the airports "Megas Alexandros" of Kavala and "Democritus" of Alexandroupolis, and the ports of the same towns. It should be noted that the Prinos oil fields, which have been producing since the 1970s and 1980s, are also located in this area.

The profile of the area includes an interesting geomorphological terrain, which illustrates the existence of extensive plains, rich natural resources, and the dominance of the agricultural sector in these areas as well as in the local economy.

It should be noted that, demographically, on the one hand, the Region of Eastern Macedonia-Thrace (with the prefectures of: Drama, Kavala, Xanthi, Rodopi \& Evros) has a population of 613,607 inhabitants, according to the Hellenic
Statistical Authority - (ELSTAT) census of 2011, presenting a decrease of $1 \%$ compared to the census of 2001 . The Prefecture of Serres has another 176,430 inhabitants; hence this wider region has a population of 790,037 inhabitants in total, while the total area of the six prefectures is $18,125 \mathrm{~km}^{2}$ according to data from the Hellenic Statistical Authority.

The per capita gross domestic product (GDP) of the area's prefectures varies considerably between them. Thus, the Kavala and Evros prefectures share a relatively equal position, with GDP in Kavala calculated at $€ 13,241$ in 2015, with a decrease of $-27.9 \%$ compared to the corresponding amount in 2008 (in essence, well before the decade-long recent crisis), while in Evros, the corresponding figures are $€ 12.072$ and $-21.8 \%$. The other counties range at lower levels, namely Drama with $€ 10.635$ and $-20.4 \%$, Serres with $€ 9,684$ and $-15.2 \%$, Xanthi with $€ 9,549$ and $-34.3 \%$, and finally Rodopi with $€ 9,533$ and $-37 \%$. It is worth noting that the national GDP for the whole country respectively is moving towards a significantly higher level, namely $€ 16,294$, while the decline between 2008 and 2015 is at the level of $-24.4 \%$.

Regarding the significant infrastructure in the said region, it should be noted that the highway, named Egnatia Road, which connects the Middle East with the European continent, crosses the area, ensuring easy, safe and fast transportation of all products, including agricultural products. Moreover, the vertical axes of Greece's connection to Bulgaria which are under completion (Alexandroupolis - Ormenio, Komotini Nymphaia, Xanthi - Echinos, Kavala - Drama - Exochi \& Serres - Promahonas) will make transportation easier, while the area will acquire an important developmental advantage in the movement of products and people. The rail network that crosses the area cannot be considered as meeting modern needs since, beyond the problems to do with its age and the neglect followed in modernizing the network for many decades now, it follows a mountainous inland route, and it is not connected to any major ports (except Alexandroupolis). The completion of the Egnatia railway project will constitute a significant achievement in this area. When completed, this project will provide an extraordinary developmental impetus to the area, which will have a modern railway network, at the same time that the area is also expected to have rail links to the ports of Ruse on the Bulgarian-Romanian border, the ports of Varna and Burgas in Bulgaria, and of course with Thessaloniki.

The area has two major ports, in Alexandroupolis and Kavala. It should in fact be noted that Kavala has a distinct set of ports, which makes it more complex, since there is a different passenger port located in the city center (named, the Port of Paul the Apostle), while a different commercial port exists in the eastern part of the city (named, the Port of the King of Macedonia, Philip the $2^{\text {nd }}$ ).

Historically and culturally, it should be noted that there are significant archaeological sites located in the area, such as the ancient cities of Philippi (included in the list of UNESCO World Heritage Sites), Amphipolis, Maroneia, Avdera, Thasos and Platinoupolis, and an extremely large number of monuments and prehistoric settlements (such as that of "Dikili Tas", or "Megalo Lithari"), as well as other historical monuments from ancient Greek, Roman, Byzantine and modern times.

As far as the structure of agriculture in the area is concerned, the main crops are annual, the most significant being cereals, which cover about $50 \%$ of the agricultural land. Also important to the area is the cultivation of cotton as well as, to a lesser extent, the cultivation of rapeseed and sunflower. It should be emphasized, however, that intensive 
cultivation has been developed, especially in the western part of the area and specifically in the prefecture of Kavala, which utilizes high amounts of capital and labor in their establishment and annual cultivation, while producing high quality products that are standardized, certified and exported in their majority, delivering significant benefits to both the local and national economy of the country. Such crops consist mainly of table grapes, kiwifruit, asparagus, a variety of vegetables, edible olives and olive oil, among others. This area also produces quality wines, consumed both in Greece and abroad, as well as other products.

Concerning the grape varieties grown in the area, according to data sourced from the Directorates of the Rural Economy and Veterinary Medicine, about 2,230 hectares of wine-making grape varieties are cultivated in these six prefectures. The areas of grape cultivation of the wine varieties are indicatively distributed among the six prefectures, as shown in Table 1, below. Moreover, based on the data available from the same services, there are 85 wineries operating in the stated area, which can be broken down as illustrated in same Table:

Table 1. Distribution of wine grapes in the area (data sourced from the Rural Economy \& Veterinary Medicine, the Directorates)

\begin{tabular}{|c|c|c|}
\hline & $\begin{array}{r}\text { Distribution } \\
\text { of wine } \\
\text { grapes }\end{array}$ & Wineries \\
\hline Serres & $22.0 \%$ & 24 \\
\hline Drama & $23.5 \%$ & 13 \\
\hline Kavala & $20.0 \%$ & 19 \\
\hline Xanthi & $4.5 \%$ & 10 \\
\hline Rodopi & $9.0 \%$ & 5 \\
\hline Evros & $21.0 \%$ & 14 \\
\hline TOTAL & $100 \%$ & 85 \\
\hline
\end{tabular}

The vast majority of the above-mentioned wineries have developed over the last 25 years. This also reveals the dynamics that the winemaking industry in the area is seeking to acquire, after decades in which it had virtually ceased to exist, as stated in the introductory section. In this area, the cultivation of grape varieties for wine-making is thriving in all prefectures, while the cultivation of table grape varieties is almost exclusively limited to the prefecture of Kavala. Nevertheless, the area is highly heterogeneous in terms of the prevailing soil/climate conditions.

The Hellenic National Meteorological Service - EMY maintains a limited number of stations in the area. Although the figures may be considered insufficient, they nevertheless have a significant value because, when comparing one year with another, they reflect variations from one crop year to another crop year.

The EMY service maintains five monitoring stations for temperature and relative humidity: Serres, Kavala, Drama, Xanthi and Alexandroupolis. Among these stations, information regarding annual precipitation levels is available from the regional stations of Serres, Kavala and Alexandroupolis.

Thus, based on data from the EMY, concerning the yearly temperature as annual maximum, minimum and average levels, a rather uniform state emerges, as expressed in Table 2, below.

Observing the evolution of temperature values during the vegetation season at the Serres meteorological station (data available from 2008 to 2019), it can be observed that the maximum monthly temperature reached in August 2018 was $31.83^{\circ} \mathrm{C}$ while the minimum was recorded in April 2014 at $14.25^{\circ} \mathrm{C}$. At the Kavala station, the corresponding values recorded in July 2012 were $28.4^{\circ} \mathrm{C}$, a value that is similar with that of the August 2010 minimum of $28.39^{\circ} \mathrm{C}$, with a minimum value in the April 2011 vegetation period of 12.750 C. In Drama the maximum monthly value in the vegetation season was recorded as $30.28^{\circ} \mathrm{C}$ in June 2016 , while the lowest value was recorded in April 2015 at $12.98^{\circ} \mathrm{C}$. The station in Xanthi, which has been operating since 2014, recorded a maximum value of $28.311^{\circ} \mathrm{C}$ in August 2018, while the minimum value reached in the vegetation season was $13.75^{\circ} \mathrm{C}$ in April 2017. Finally, the Alexandroupolis station recorded, respectively, a maximum value of $30.3^{\circ} \mathrm{C}$ in July 2012 and a minimum of $12.15^{\circ} \mathrm{C}$ in April 2011.

Table 2. Variation in average annual temperature in the area

\begin{tabular}{l|r|r|r}
\hline & $\begin{array}{c}\text { Temperatu } \\
\text { re, } \mathbf{m a x} \\
\left({ }^{\circ} \mathbf{C}\right)\end{array}$ & $\begin{array}{c}\text { Temperatu } \\
\text { re, min } \\
\left({ }^{\circ} \mathbf{C}\right)\end{array}$ & $\begin{array}{c}\text { Temperatu } \\
\text { re, } \\
\text { Average } \\
\left({ }^{\circ} \mathbf{C}\right)\end{array}$ \\
\hline Serres & 17.12 & 16.09 & 16.62 \\
Kavala & 16.73 & 15.20 & 16.18 \\
Drama & 16.93 & 15.37 & 16.22 \\
Xanthi & 17.18 & 16.28 & 16.73 \\
Alexandroup & 16.84 & 15.21 & 16.42 \\
olis & & & \\
Source: EMY - Greece & \multicolumn{3}{l}{}
\end{tabular}

At these same stations, the annual development of the relative humidity was also recorded, at average, maximum and minimum levels, for the years 2008 - 2019, as shown in Table 3, below:

Table 3. Variation of the average annual relative humidity in the area

\begin{tabular}{l|c|c|c}
\hline & $\begin{array}{c}\text { Relative } \\
\text { humidity, } \\
\text { max } \\
\mathbf{( \% )}\end{array}$ & $\begin{array}{c}\text { Relative } \\
\text { humidity, } \\
\text { min } \\
\mathbf{( \% )}\end{array}$ & $\begin{array}{c}\text { Relative } \\
\text { humidity, } \\
\text { Average } \\
\mathbf{( \% )}\end{array}$ \\
\hline Serres & 70,56 & 63,12 & 65.81 \\
Kavala & 75.52 & 67.51 & 70.12 \\
Drama & 73.10 & 64.89 & 68.46 \\
Xanthi* & 67.15 & 67.15 & 67.15 \\
Alexandroupolis & 94.27 & 63.67 & 68.78 \\
\hline
\end{tabular}

Source: EMY Greece

* It is unusual for the three values to be completely identical, even though this is how it is recorded in the data from the EMY

If we look at the values during the vine growing season, we can see that the Serres station has recorded monthly average values for the years 2008-2019, ranging from $41.96 \%$ to $72.84 \%$. Correspondingly, the same values of the Kavala station range from $52.84 \%$ to $82.36 \%$, while those for Drama range from $47.54 \%$ to $74.74 \%$. The corresponding station in Xanthi recorded relative humidity values from $47.34 \%$ to $99.77 \%$, which is the highest value. Finally, the Alexandroupolis station recorded a minimum average of $43.54 \%$ for the month during the vegetative growth period, while the highest respective value recorded was $74.89 \%$.

Regarding annual rainfall, data from the same civil service of the three stations (Table 4 ) in the area show that during the last decade (2008 - 2019), the area of Alexandroupolis achieved a higher rainfall level compared to the average levels of Kavala and Serres. The high fluctuation in the rainfall from year to year should be noted here, as the maximum rainfall per year is even more than three times the corresponding 
minimum annual amount. The highest annual rainfall was recorded at all three stations in 2014, while the minimum was in Kavala and Alexandroupolis in 2008 and in Serres in 2011. Moreover, the rainfall distribution throughout the year is very typical for the area, with little rainfall during the summer months and most of the rains falling in the winter months, while there are also months when zero rainfall is recorded.

Table 4. Variation of rainfall in the area

\begin{tabular}{l|c|c|c}
\hline & $\begin{array}{c}\text { Rain per } \\
\text { year, } \\
\text { max } \\
(\mathbf{m m})\end{array}$ & $\begin{array}{c}\text { Rain per } \\
\text { year, min } \\
(\mathbf{m m})\end{array}$ & $\begin{array}{c}\text { Rain per } \\
\text { year, } \\
\text { Average } \\
\text { (mm) }\end{array}$ \\
\hline Serres & 766.9 & 374.5 & 510.4 \\
Kavala & 968.2 & 227.3 & 534.2 \\
Alexandroupolis & 805.0 & 275.7 & 677.6 \\
\hline Source: EMY Greece
\end{tabular}

The description of the climatic characteristics of the area is particularly important; from the literature surveys, it should be emphasized that the dominant view on wine production focuses on the relationship of the area and the wines produced there, with the prevailing view that grape production in a particular area is strongly influenced by the local environment, which is 'transposed' to the wines produced in the area. For this reason, most of the time, the wines are marketed under the name of the region where they are produced [13]. In the same vein, other scientific research indicates that climate and viticulture are unequivocally linked, and therefore, knowledge of the climatic conditions of an area is essential for optimal variety selection, sustainable production and overall wine quality [100]. Scientists are now approaching the issue of climate change in relation to the production of wine grapes and winemaking.

\subsection{Purpose of the study}

The purpose of the analyses carried out in this study is not simply to apply European and Greek legislation in order to satisfy the formal requirements of national and, in particular, Community law; the main purpose of these analyses is, inter alia, to safeguard the quality of the wines produced with whatever this entails for the economic, developmental, as well as historical and cultural aspects of the wines. Hence, preserving and enhancing the quality of the wines produced will contribute decisively to serving the interests of not only the winemaker and, by extension, the vine grower, but also the consumer.

In this context, the purpose of the present work is to describe the checks carried out on the wine samples that were conducted according to legislative procedures, in order to classify them and to draw scientific conclusions based on these data and their processing. The sampling was carried out using the relevant instructions of the competent Ministry, so that the results obtained from the analyses reflect the total wine production. It should be noted that the various competent services where the analyses were conducted are staffed by highly experienced scientific personnel consisting mainly of agronomists, which contributes to the credible implementation of the Ministry's guidelines, and also to the reliability of the sampling process, enabling the conclusions of this work from the samples tested to be extended to all the wines produced.

The classification and evaluation of the results is an important first step in this work. Following the statistical processing, further conclusions can be drawn from the results of the analyses. The third step involves correlating the results (of whichever part of the results is feasible) with the climatic data. The attempt to correlate the results of the analyses with the climatic data is of particular interest, since the climatic data, as explained previously, influence the characteristics of the produced wine, and this may to some extent affect the results of the analyses.

The analyses that take place, presenting twelve years' worth of work, together with the data processing resulting from the control checks, advocate the continuation of the application and possibly the extension of the quality control of wine, so that this effort will lead the promotion of a higher overall quality of wine, a highly prized product all over the world. This effort works to the benefit of protecting the interests of struggling vine growers and winemakers. Apart from continuing and expanding the application of quality control, it is also intended to provide additional evidence for the benefit of the research efforts made towards this direction. At this point, an additional purpose to the study should be noted, which emerged from the literature surveyed in the previous chapter, which is the study of the conclusions of this work, in view of the evolving climate change.

It is a fact that, up to now, the data harvested from the specific analyses were not sought after for scientific use; thus, the efforts made in this work also acquire innovative features concerning the specific wines and area being investigated.

The sampling carried out by the competent authorities, which have an experienced scientific staff consisting mainly of experienced agronomists, is what constitutes the reliability, in terms of the extension of the conclusions of this study, from the samples of wine that were actually analyzed to all the wines that are produced in the area.

In this context, the present scientific work aims to present the results of the analyses and all other data that co-exist with them. After the statistical processing of the data, correlations of the results will be made with the available climatic data of the area in order to reveal the relationships among the characteristics of the area.

\section{Research Methodology}

\subsection{Implementation of analyses on wine samples by the competent authority}

The Ministry of Rural Development and Food, as previously mentioned, in accordance with European regulations and Greek legislation, conducts a series of random checks and analyses on the wines produced in the area. A small number of tests have also been carried out in recent years on wines produced elsewhere. These tests were carried out by sampling at trading stores and liquor supplies. These analyses are carried out by the competent decentralized services of the Regional Centers for Plant Protection, Quality and Phytosanitary Control, which have the appropriate laboratory infrastructure and staff to perform such tests.

Before conducting the analyses, the first step involves performing the sampling in an appropriate manner, to ensure the representativeness of the sample, and thus the validity of the resulting analyses as well as the possibility of extending the results. The Greek Ministry of Rural Development and Food has assigned the role of sampling by documentation through a set of guidelines since 2004, not only at the Regional Centers for Plant Protection, Quality and Phytosanitary Control, but also with the Departments of Rural Economics and Veterinary Medicine [101]. It should be noted that these services, which are also staffed by qualified scientific personnel (mainly agronomists, etc.) are not 
ministerial services; they are provided by the administrative centers of the region run by elected administrations since 2010. In this particular case, the experience of the sampling procedure has shown that, for practical reasons, these tests are mainly carried out by the departments of the regions, due to their close proximity to the wineries. At the same time, however, this provides an additional guarantee of impartiality, since the sampling is carried out by a service other than the one conducting the controls and analyses, especially in consideration of the fact that this service comprises an elected regional administration.

The guidelines specify four different examples of sampling:
A. Sampling from a tank,
B. Sampling from barrels,
C. Sampling from other containers (eg kegs, ship tanks etc.), and
D. Sampling of packaged products (eg bottles, bags in boxes, tetrapack, etc.).

In case $\mathrm{A}$, it is foreseen that the wine will have previously been stirred or recirculated, with the responsibility of the winemaker, while it is also defined that sampling is not allowed to take place from the bottom of the storage tank. On the contrary, the use of the sampling valve is foreseen when sampling takes place at two-thirds the depth of the tank. In case B, sampling is foreseen to comprise at least $10 \%$ of the total number of barrels while it is mandatory that the quantities obtained from the barrels must be equal among them. In case $C$, sampling takes place with a suitable sampling implement from two-thirds the depth of the tank. In case D, especially for standard wine bottles, it is specified that the sample must be taken from a batch of three bottles of $750 \mathrm{ml}$ each (based on Lot Number). Alternatively, for larger volumes of more than 2 liters, this sampling is specified from at least two bottled specimens using three $750 \mathrm{ml}$ bottles.

In addition, the same document provides for a triplicate sample in cases where the wine product is considered suspect or spoiled. Also included are the data and the sampling protocol, as well as the sampling docket which is affixed to the bottles. Procedurally, the guidelines specify that one sample must be analyzed in the laboratory in order to make the required determinations, one sample is kept with the competent authority in case of potential objections, while the third one is kept at the winery where the sampling took place.

The specific ministerial document also applies to other wine products (e.g. must, etc.) but these are not included in the scope of this work. The procedure described above is compulsorily applied throughout the country, and of course in the area of competence of the Kavala Regional Center for Plant Protection, Quality and Phytosanitary Control, resulting in the wine sampling taken to the laboratory of this particular civil service.

\subsection{Statistical discrimination of red and white dry wines which have the PGI label, according to geographical origin}

Multivariate Analysis of Variance (MANOVA) was performed at the beginning of the statistical analysis in order to determine those elements that are important for the existence of differences in the samples of dry white wines among the four different areas. The total number of the characteristics comprised the dependent variables of the analysis, while the geographical origin was taken as independent variable.
For this procedure, from the wine samples of the area that were examined in the laboratory, only those of dry wines were included in this treatment, as they constitute the vast majority of the samples and they are included in the PGI lists, while they also meet the PGI conditions and specifications. Statistical processing took place separately for red and white wines, as co-processing them would probably confuse the statistical procedure due to their different characteristics, and thus dilute the quality of obtaining substantial results.

Due to the number of samples per PGI, the application of statistical separation took place on only three more complex PGI groups, i.e. the Serres PGIs, the Drama PGIs, and the Paggaio PGIs. The remaining PGIs of the area were not included in the analysis due to the very small number of samples.

Following the analysis, the significant data obtained from MANOVA were used to determine whether a distinction could be made concerning the origin of the red and white wines in the three different areas. Linear Discriminant Analysis (LDA) was performed for this reason. Fisher coefficients were used in order to calculate the load factors on the discrimination functions, while the probability of correct ranking was calculated based on the size of the groups, since the number of samples from each area was not the same. Both original and "leave one out" cross validation methods were used to test the prediction classification ability. According to [102], cross-validation by the "leave one out" method is a more conservative method for correct classification ability, and at the same time a more reliable one. This is more conservative because it always gives lower rates of correct prediction [102]. Likewise, it is more reliable because it does not only reflect the prediction rates for a tested sample, but the results can be generalized among the population of tested samples. It, thus, further strengthens the discrimination efforts. This is due to the fact that it calculates the corresponding percentages leaving one observation out of the analysis at each iteration. Thus, it creates a discrimination function and then classifies the observation left to the groups which are created based on this function. This is done for all observations in the sample, leading to a more reliable discrimination. In order to check the homogeneity of the variances, the statistical test of Box's M was used, which is a crucial assumption for reliable results, especially when the sample sizes are unequal [102].

It goes without saying that this statistical process has an indicative nature for all the wines produced in the area. Moreover, as already described, this procedure was followed so that the samples examined in the context of quality control and the legislation provisions could be extended to all the wines produced.

\subsection{Co-variance analysis per dependent variable}

The General Linear Model was used in order to investigate the effect of each of the three factors from the five wine elements to be investigated (Total Alcoholic Strength, Obtained Alcoholic Strength, Total Acidity, Volatile Acidity and Residual Sugars), and in particular, the Analysis of covariance (ANCOVA). Covariance analysis constitutes a case of the General Linear Model, and it is used when the analysis of variance includes continuous quantitative variables which are not in themselves a part of the experimental design, but they may affect the outcomes of the dependent variables [102], [103]. The key dependent variables in this analysis are Total Alcoholic Strength, Obtained Alcoholic Strength, Total Acidity, Volatile Acidity and Residual Sugars. The main variable used is the cultivation 
area of the red dry PGI-designated wines, at three levels (Drama, Serres and Paggaio). The covariates used in the analysis were Mean Seasonal Temperature of the growing season, and Mean Relative Humidity of the growing season, since these specific variables are considered likely to influence the values of each dependent variable for each of the areas investigated. At this point it should be emphasized that the basic classification variable, which is the area, is employed in the model with the use of dummy variables. Because area consists of three levels (PGI Serres, PGI Drama and PGI Paggaio), two dummy variables were used, since the number of dummy variables used is one less than the levels of the classification variable [102]-[104]. A total of 159 runs were used to design the experiment and the analysis was performed using the GLM procedure of the Minitab 19.0 statistical package [105]. The model that was fitted to each of the dependent variables is the complete linear model given by the following relation:

$Y=\beta_{0}+\sum_{j=1}^{4} \beta_{j} x_{j}+\varepsilon$

where $\beta_{j}, \mathrm{j}=1,2,3,4$ are the corresponding coefficients of the linear terms (two co-variables and two dummy variables), $\beta_{0}$ is the standard term of the model and $Y$ is the value of each dependent variable (Total Alcoholic Strength, Obtained Alcoholic Strength, Total Acidity, Volatile Acid and Residual Sugars). Finally, $\varepsilon$ is the random error in the whole model in the analysis. Contour plots were then used for each of the areas under investigation. Through these graphs, as well as the Response Optimization process, the researcher can determine which intervals of factor and co-variable combinations can give the maximum and/or minimum value of the dependent variables, with a very high level of approximation [103].

An effort to apply the model for white wines of the same PGI did not yield any results; it is therefore recommended that this should take place for white wines when a greater number of results are available from a sample analysis.

\subsection{Implementation of time-series charts}

In the context of the research, a time-series study was attempted with an exploratory purpose, by creating the relevant scatter plots. Time-series analysis was attempted for the dry red wines: PGI Serres, PGI Drama and PGI Paggaio, i.e. for the three categories which include most wine samples. The choice of red PGI wines was adopted because they have a defined composition. In the design of the scatter plots, the year of the grape harvest was used, and not the year when the sampling and analysis were performed.

The purpose of the analysis is to determine to what extent a trend exists in the characteristics of dry red wines (Total Alcoholic Strength, Obtained Alcoholic Strength, Total Acidity, Volatile Acidity and Residual Sugars), as determined by the analyses which were carried out in relation to the evolution of climate phenomena that are affecting the vineyards and grapes produced, and subsequently the wines made from them. In the case of PGI Paggaio and PGI Serres, the Mean Seasonal Temperature and Mean Relative Humidity of the growing season, and the precipitation level throughout the year were used. For the area of Drama, the Mean Seasonal Temperature and Mean Relative Humidity of the growing season were used, since no precipitation data were available.

Implementation of the time series and the layout of the timetables did not extend beyond the three most numerous
PGI cases, because the limited number of samples did not allow the creation of safe and reliable time-series charts.

It should be noted that the results are absolutely indicative and descriptive in nature and provide only evidence for the presence or absence of some trends in the correlations of the climatic parameters and the characteristics of the grapes which were identified in the analyses.

\section{Results and discussion}

\section{Results of the analyzes carried out}

The laboratory of the competent decentralized service of the Ministry of Rural Development \& Food is run by the Regional Center for Plant Protection, Quality and Phytosanitary Control of Kavala and has been carrying out analyses since 2008 till the present time. It performs all the prescribed analyses, which include significant determinations for the wine in the area served by the laboratory. As stated above, the seven Directorates of Rural Economy \& Veterinary Medicine (Table 5) of the relevant regional prefectures carried out the statutory sampling as prescribed by the law, in order to obtain the samples used in the laboratory tests.

Table 5. Rural Economy \& Veterinary Departments, Regional Authorities operating in the competent area of the Kavala Regional Center for Plant Protection, Quality and Phytosanitary Control, which contribute to wine sampling.

\begin{tabular}{|c|c|c|}
\hline & Region & $\begin{array}{l}\text { Regional Authorities in the area of } \\
\text { responsibility }\end{array}$ \\
\hline 1 & $\begin{array}{l}\text { Central } \\
\text { Macedonia }\end{array}$ & $\begin{array}{l}\text { Directorate of the Rural Economy \& } \\
\text { Veterinary Medicine of Serres }\end{array}$ \\
\hline 2 & $\begin{array}{l}\text { East } \\
\text { Macedonia - } \\
\text { Thrace }\end{array}$ & $\begin{array}{l}\text { Directorate of the Rural Economy \& } \\
\text { Veterinary Medicine of Drama }\end{array}$ \\
\hline 3 & $\begin{array}{l}\text { East } \\
\text { Macedonia - } \\
\text { Thrace }\end{array}$ & $\begin{array}{l}\text { Directorate of the Rural Economy \& } \\
\text { Veterinary Medicine of Kavala }\end{array}$ \\
\hline 4 & $\begin{array}{l}\text { East } \\
\text { Macedonia - } \\
\text { Thrace }\end{array}$ & $\begin{array}{l}\text { Directorate of the Rural Economy \& } \\
\text { Veterinary Medicine of Xanthi }\end{array}$ \\
\hline 5 & $\begin{array}{l}\text { East } \\
\text { Macedonia - } \\
\text { Thrace }\end{array}$ & $\begin{array}{l}\text { Directorate of the Rural Economy \& } \\
\text { Veterinary Medicine of Rodopi }\end{array}$ \\
\hline 6 & $\begin{array}{l}\text { East } \\
\text { Macedonia - } \\
\text { Thrace }\end{array}$ & $\begin{array}{l}\text { Directorate of the Rural Economy \& } \\
\text { Veterinary Medicine Alexandroupolis } \\
\text { (Evros) }\end{array}$ \\
\hline 7 & $\begin{array}{l}\text { East } \\
\text { Macedonia - } \\
\text { Thrace }\end{array}$ & $\begin{array}{l}\text { Directorate of the Rural Economy \& } \\
\text { Veterinary Medicine Orestiada } \\
\text { (Evros) }\end{array}$ \\
\hline
\end{tabular}

It should be noted that the relevant laboratory was not operational in 2009 for reasons related to the service itself and the relevant Ministry, and not to this study; hence, data no analyses were made in 2009, and there are no available data for that year. A total of 518 analyses were performed from 2008 to November 2019, analyzed per year shown in Table 6, below:

Table 6. Number of analyses of wine samples carried out per year.

\begin{tabular}{l|lr|l}
\hline Year & $\begin{array}{l}\text { Analyzed } \\
\text { samples }\end{array}$ & Comments \\
\hline 2008 & & 13 & \\
2009 & & 0 & \\
2010 & & 36 &
\end{tabular}




\begin{tabular}{l|l|l}
2011 & 64 & \\
2012 & 49 & \\
2013 & 45 & \\
2014 & 24 & \\
2015 & 33 & \\
2016 & 70 & \\
2017 & 47 & \\
2018 & 89 & The 4 samples come from \\
& 48 & $\begin{array}{l}\text { A. The 5 samples come } \\
\text { from trading stores }\end{array}$ \\
2019 & & $\begin{array}{l}\text { B. The samples taken into } \\
\text { account in this study were }\end{array}$ \\
& & analyzed up to November \\
& & \\
& 518 & \\
\hline TOTAL &
\end{tabular}

The Annex of this work provides the results of the analyses by prefecture. Apart from the sampling at the area's wineries, nine analyses of wine samples were obtained from local beverage outlets in the area; thus, an equal number of wine samples from other parts of the country were also obtained. The number of these samples totals four in 2018, and five in 2019. Therefore, in total, of the 518 analyses, 509 relate to wines produced in the region, while the remaining nine relate to wine samples from other regions, which are available on the market.

It is however highlighted that, in many cases, the sampled wines (in particular, the red wines) refer to grape harvests from previous years. From the data recorded in the results of the analyses, it is evident that a significant part of the wines analyzed here are actually wines which fall under one of the prescribed categories of wines. EC Regulations Nos. $479 / 2008$ \& 607/2009 contain systematic rules for the classification of wines. The legislation governing wines, PDO $\&$ PGI wines in particular, are posted on the website of the Greek Ministry of Rural Development \& Food [106]

Instead of the full designations of the main wine categories, according to the regulations in force as provided on the websites of the Ministry and KEOSOE, some shorter references are made here to each category in simplified form:

Protected Geographical Indication (PGI): wines in this category owe their quality and reputation to a geographical area that produces at least $85 \%$ of the grapes used in their production, while production takes place in the specific region.

Local Wines or Vin de pays (LW): this particular wine category is included in PGI wine lists and has similar specifications.

Traditional Appellation or Appellation traditionnelle: this wine category is included in the PGI lists, and mainly concerns wines commonly known in Greece as "retsina".

Varietal wine: these wines are characterized by the name of the variety from which they are produced, without reference to a geographical indication or designation of origin.

Organic wine: this kind of wine is made from grapes produced with organic agriculture, with particular and specific requirements concerning additives, preservatives, etc. as stipulated by EC Regulation No. 203/2012.

Protected Designation of Origin (PDO): wines in this category owe their quality and special characteristics to the particular environment of an area, while the grapes used for their production come from that particular region. The wine production process also takes place in the same region.
From 2008 to 2019, among the samples examined, the following are included: wine reported to fall under the categories of PGI, LW, a few cases of Traditional Appellation (Retsina) wines, as well as varietal wines, with very few cases of wines designated as Organic Wine, or Organic Variety Wine.

It should be noted that for 16 samples, the designation of 'table wine' is present on the label, while there is no such indication for 58 samples. It should also be highlighted that the two samples with a PDO label relate to samples collected at retail outlets, so this category is also absent from the area. Thus, apart from PDO wine, there is no case of the categories named "wines with Designation of Origin of Premium Quality" (appellation d'origine de qualité supérieure) or wines with Controlled Designation of Origin (appellation d'origine controlee) in the area (Table 7).

Table 7. Classification of wines in the area as recorded in the results of the analyses

\begin{tabular}{r|l|r}
\hline & Category & $\begin{array}{r}\text { Number of } \\
\text { samples }\end{array}$ \\
\hline 1 & PGI Avdera & 11 \\
2 & LW Avdera & 3 \\
3 & PGI Agora & 1 \\
4 & PGI Attiki & 4 \\
5 & PGI Drama & 82 \\
6 & LW Drama & 18 \\
7 & PGI Evros & 3 \\
8 & PGI Thasos & 1 \\
9 & PGI Thraki & 6 \\
10 & LW Thraki & 1 \\
11 & PGI Ismaros & 8 \\
12 & LW Ismaros & 4 \\
13 & PGI Kavala & 3 \\
14 & PDO Limnos & 1 \\
15 & PGI Macedonia & 12 \\
16 & LW Macedonia & 13 \\
17 & PDO Nemea & 1 \\
18 & PGI Paggaio & 23 \\
19 & LW Paggaio & 6 \\
20 & PGI Peloponnisos & 5 \\
21 & PGI Serres & 134 \\
22 & LW Serres & 80 \\
23 & PGI Sterea Ellada & 1 \\
24 & Traditional Appellation, Retsina & 4 \\
25 & Varietal wine & 14 \\
26 & Organic Varietal wine & 58 \\
27 & Organic wine & \\
28 & Table wine & \\
29 & Wines without any & recorded \\
& categorization evidence & \\
\hline & & \\
\hline
\end{tabular}

EU legislation, particularly Regulation (EC) No $607 / 2009$, stipulates that Local Wines and Traditional Appellation or Appellation traditionnelle wines (e.g. retsina) are included among the wines with a Protected Geographical Indication; thus, based on Community legislation, the above elements are formulated as illustrated in Table 8 below:

Table 8. Wine categories in the area from the analyzed samples

\begin{tabular}{r|l|r}
\hline & Category & $\begin{array}{l}\text { Number of } \\
\text { samples }\end{array}$ \\
\hline 1 & PGI Avdera & 14 \\
2 & PGI Agora & 1
\end{tabular}




\begin{tabular}{|c|c|c|}
\hline 3 & PGI Attiki & 4 \\
\hline 4 & PGI Drama & 100 \\
\hline 5 & PGI Evros & 3 \\
\hline 6 & PGI Thasos & 1 \\
\hline 7 & PGI Thraki & 7 \\
\hline 8 & PGI Ismaros & 12 \\
\hline 9 & PGI Kavala & 3 \\
\hline 10 & PDO Limnos & 1 \\
\hline 11 & PGI Macedonia & 25 \\
\hline 12 & PDO Nemea & 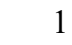 \\
\hline 13 & PGI Paggaio & 29 \\
\hline 14 & PGI Peloponnisos & 5 \\
\hline 15 & PGI Serres & 214 \\
\hline 16 & PGI Sterea Ellada & 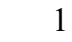 \\
\hline 17 & Traditional Appellation, Retsina & 4 \\
\hline 18 & Varietal wine & 14 \\
\hline 19 & Organic Varietal wine & 4 \\
\hline 20 & Organic wine & 1 \\
\hline 21 & Table wine & 16 \\
\hline 22 & $\begin{array}{l}\text { Wines without any recorded } \\
\text { categorization evidence }\end{array}$ & 58 \\
\hline & TOTAL & 518 \\
\hline
\end{tabular}

Therefore, the samples that were analyzed in the laboratory of the competent authorities according to the total wine classification for PGI and other categories are presented in Table 9:

Table 9. Classification of the wines of the area from the samples examined according to the wine category.

\begin{tabular}{|c|c|c|c|}
\hline & Category & $\begin{array}{l}\text { Number } \\
\text { of } \\
\text { samples }\end{array}$ & $\begin{array}{c}\text { Percentage, } \\
\%\end{array}$ \\
\hline 1 & PGI & 423 & 81.66 \\
\hline 2 & PDO & 2 & 0.39 \\
\hline 3 & Varietal wine & 14 & 2.70 \\
\hline 4 & $\begin{array}{l}\text { Wines with reference to } \\
\text { organic cultivation }\end{array}$ & 5 & 0.97 \\
\hline 5 & Table wine & 16 & 3.09 \\
\hline 6 & $\begin{array}{ll}\text { Wines without any } \\
\text { recorded } \\
\text { evidence }\end{array}$ & 58 & 11.20 \\
\hline & TOTAL & 518 & 100.00 \\
\hline
\end{tabular}

It is highly significant that more than $80 \%$ of the wines analyzed in the laboratory of the competent authorities relate to Protected Geographical Indication wines while the other categories of designation of origin wines are absent from the area. A low percentage of varietal wines are recorded $(2.7 \%)$ while less than $1 \%(0.97 \%)$ concern cases of wines related to organic farming. Finally, just over 3\% (3.09\%) concern cases of table wines. The remaining $11.2 \%$ relate to cases where no categorization of the sample has been recorded, but this cannot be interpreted as referring to cases where sampling was conducted from barrels and tanks (26 cases), or to cases where for other reasons, no relevant records were recorded.

Concerning the origin of the samples, it should be noted that more than half of the samples come from the prefecture of Serres $(53.05 \%)$, almost a quarter come from the prefecture of Drama $(24.95 \%)$, while the remaining samples come from the other prefectures, with Kavala holding 7.27\%, Evros $5.3 \%$, Xanthi and Rodopi $4.91 \%$ and $4.52 \%$ respectively (Table 10).

Table 10. Wine samples analyzed according to the area they came from.

\begin{tabular}{|c|c|c|c|}
\hline & Regional District & $\begin{array}{l}\text { Number } \\
\text { of } \\
\text { samples }\end{array}$ & $\begin{array}{c}\text { Percentage, } \\
\%\end{array}$ \\
\hline 1 & Serres & 270 & 53.05 \\
\hline 2 & Drama & 127 & 24.95 \\
\hline 3 & Kavala & 37 & 7.27 \\
\hline 4 & Xanthi & 25 & 4.91 \\
\hline 5 & Rodopi & 23 & 4.52 \\
\hline 6 & Evros & 27 & 5.30 \\
\hline \multirow{3}{*}{7} & Samples from area's wines & 509 & 100.00 \\
\hline & $\begin{array}{r}\text { Samples from trading } \\
\text { stores }\end{array}$ & 9 & \\
\hline & TOTAL & 518 & \\
\hline
\end{tabular}

It should be noted that of the 518 wine samples, the overwhelming majority $(92.08 \%)$ are dry wines, while the other wine types, such as semi-dry wines $(3.67 \%)$, semi-sweet wines $(3.47 \%) \%$ ) and sweet wines, are much fewer in number with a percentage lower than $0.77 \%$ (Table 11 ).

Table 11. Wine samples analyzed according to the type of wine.

\begin{tabular}{|c|c|c|c|}
\hline & Type of wines & $\begin{array}{l}\text { Number } \\
\text { of samples }\end{array}$ & $\begin{array}{c}\text { Percentage, } \\
\%\end{array}$ \\
\hline 1 & Dry & 477 & 92.08 \\
\hline 2 & Semi - dry & 19 & 3.67 \\
\hline 3 & Semi - sweet & 18 & 3.47 \\
\hline \multirow[t]{2}{*}{4} & Sweet & 4 & 0.77 \\
\hline & TOTAL & 518 & 100.00 \\
\hline
\end{tabular}

Regarding color classification, red and white wines account for equal percentages for approximately $44 \%$ of the samples tested, while rosé wines range slightly above $11 \%$. Table 12 shows the distribution of the wines by color. It can inferred that both red and white wines are dominated by dry varieties, in contrast to rosé wines, where almost half are semi-dry and semi-sweet wines.

Table 12. Wine samples analyzed for wine color and type of wine.

\begin{tabular}{|c|c|c|c|c|}
\hline & $\begin{array}{l}\text { Colour } \\
\text { of wine }\end{array}$ & $\begin{array}{c}\text { Number } \\
\text { of } \\
\text { samples }\end{array}$ & $\begin{array}{c}\text { Percentage, } \\
\%\end{array}$ & $\begin{array}{c}\text { Type of wines } \\
\text { between } \\
\text { colors }\end{array}$ \\
\hline \multirow[t]{6}{*}{1} & Red & 231 & & Dry red wines: \\
\hline & wines & & 44.59 & 221 \\
\hline & & & & Semi - dry red \\
\hline & & & & Semi - sweet \\
\hline & & & & red wines: 6 \\
\hline & & & & $\begin{array}{r}\text { Sweet red } \\
\text { wines: } 3\end{array}$ \\
\hline \multirow[t]{5}{*}{2} & Rose & 59 & & Dry rose \\
\hline & wines & & 11.39 & wines: 32 \\
\hline & & & & $\begin{array}{r}\text { Semi }- \text { dry } \\
\text { rose wines: } 15\end{array}$ \\
\hline & & & & Semi - sweet \\
\hline & & & & $\begin{array}{r}\text { rose wines: } 12 \\
\text { Sweet red }\end{array}$ \\
\hline \multirow[t]{5}{*}{3} & White & 228 & & $\begin{array}{l}\text { wines: - } \\
\text { Dry white }\end{array}$ \\
\hline & wines & & 44.02 & wines: 224 \\
\hline & & & & Semi - dry \\
\hline & & & & $\begin{array}{l}\text { White wines: } 3 \\
\text { Semi - sweet } \\
\text { white wines: - }\end{array}$ \\
\hline & & & & \\
\hline
\end{tabular}




\begin{tabular}{l|r|r|r|r} 
& & & $\begin{array}{r}\text { Sweet white } \\
\text { wines: } 1\end{array}$ \\
\hline & TOTAL & 518 & 100.00 & \\
\hline
\end{tabular}

The analysis also shows that there is a difference between the year of harvest and the year of sampling in red wines, with the temporal distance averaging 2.55 years between the year of harvest and the year of sampling and analysis. More specifically, more than $60 \%$ of the samples were taken up to two years after the grape harvest, approximately 34\% from about 3 to 5 years, while almost $4 \%$ refer to samples up to 10 years after the grapes they were made with were harvested. Finally, less than $1 \%$ refers to samples which are older than a decade from the time their grape harvest took place (Table 13).

Table 13. Years between harvest of the grapes and sampling and analysis of red wine varieties

\begin{tabular}{|c|c|c|c|}
\hline & $\begin{array}{l}\text { Years between grape } \\
\text { harvest and wine } \\
\text { sampling and analysis }\end{array}$ & $\begin{array}{l}\text { Number of } \\
\text { samples }\end{array}$ & $\begin{array}{c}\text { Percentage, } \\
\%\end{array}$ \\
\hline 1 & $<2$ years & 138 & 60.79 \\
\hline 2 & between 3 and 5 years & 78 & 34.36 \\
\hline 3 & between 6 and 10 years & 9 & 3.96 \\
\hline 4 & $>10$ years & 2 & 0.88 \\
\hline & Subtotal & 227 & 100.00 \\
\hline \multirow[t]{2}{*}{5} & insufficient information & 4 & \\
\hline & TOTAL & 231 & \\
\hline
\end{tabular}

Concerning white and rosé wines, since the notion of aging is not a factor that affects them, for this reason, the average time range between the year of the grape harvest and the year of sampling and analysis is 1.07 years for white and 1.12 for rosé wines, with very few cases exceeding one year, particularly one year after the grape harvest: it is longer for approximately $16 \%$ of the white and $17 \%$ of the rosé wines (Tables $14 \& 15$ ).

Table 14. Years between grape harvest and wine sampling and analysis of white wine varieties

\begin{tabular}{|c|c|c|c|}
\hline & $\begin{array}{l}\text { Years between grape } \\
\text { harvest and wine } \\
\text { sampling } \\
\text { analysis }\end{array}$ & $\begin{array}{l}\text { Number of } \\
\text { samples }\end{array}$ & $\begin{array}{l}\text { Percentage, } \\
\%\end{array}$ \\
\hline 1 & $<1$ year & 192 & 84.21 \\
\hline 2 & between 2 and 3 years & 34 & 14.91 \\
\hline \multirow[t]{2}{*}{3} & $>3$ years & 2 & 0.88 \\
\hline & TOTAL & 228 & 100.00 \\
\hline
\end{tabular}

Table 15. Years between grape harvest and wine sampling and analysis of rose wine varieties

\begin{tabular}{r|l|r|r}
\hline No. & $\begin{array}{l}\text { Years between } \\
\text { grape harvest and } \\
\text { wine sampling and } \\
\text { analysis }\end{array}$ & $\begin{array}{l}\text { Number of } \\
\text { samples }\end{array}$ & $\begin{array}{l}\text { Percentage, } \\
\%\end{array}$ \\
\hline 1 & $\begin{array}{l}<1 \text { year } \\
\text { between } 2 \text { and } 3 \\
\text { years }\end{array}$ & 49 & 83.05 \\
\hline & 10 & 16.95 \\
\hline
\end{tabular}

The data and the results of these analyses are listed, by prefecture, in the Annex to this work, as previously mentioned. From these tables, it becomes clear that for all the years since 2008 up to now, the same determinations were not being made in the context of the analyses. Thus, the determination for Free Sulphur began in mid-2008, the determination of Total Wine Solid Residues or Total Dry Extract of Wine and Wine Density began in early 2014, while the determination of Sorbic Acid Content in wine began in early 2017. In the Annex, for each analysis, the following data are provided by regional prefecture:

- Year in which the analysis took place,

- Container in which the wine was found (it should be noted that for practical reasons, the tables in the Annex list all cases EXCEPT bottles. Thus, only the samples from wooden barrels and tanks are recorded, while the empty rows refer to sampling from bottles),

- Year of harvest of the grapes,

- Wine colour,

- Wine type, and

- Wine category (i.e. if the wine belongs to a predetermined wine category such as local wines, which were later included in the list of wines with Protected Geographical Indication, wines of Protected Designation of Origin, varietal wines, etc.).

Also included in the Annex tables are the names of the winery and the wine, but this information is coded, as provided by the competent authorities, so that the wine or winery can be associated with the actual data; in this way, there is no possibility of revealing the data of the enterprises or the wines they produce, as this is by no means the purpose of the present work. The same tables also show the results of the analyses carried out, namely:

- $\quad$ Total Alcoholic Strength (\% Vol. $\left.20^{\circ} \mathrm{C}\right)$,

- Obtained Alcoholic Strength $\left(\% \mathrm{Vol} .20^{\circ} \mathrm{C}\right)$,

- Total Acidity (g/l tartaric acid),

- Volatile Acidity (meq/l),

- Total Sulphur (mg/l),

- Free Sulphur (mg/l),

- Sorbic Acid (mg/l),

- ph,

- Wine Density $(\mathrm{g} / \mathrm{ml})$,

- Total Wine Solid Residues or Total Dry Extract of Wine $(\mathrm{g} / \mathrm{l})$ - \&

- $\quad$ Residual sugars (g/l).

The nineteen (19) recorded data elements (including the codenames of the winery and each different wine), together with the other data provided in the present study, shape an important image about the quality of the wines produced by the area, as determined by the laboratory tests. In addition to the requirements, controls and analyses provided by the existing legislation, the quality of the wine is also assessed by taste tests.

Concerning the definitions that refer to volume, as specified in the analyses, the document referred to in the introductory chapter of this study, entitled "List and description of the analytical methods referred to in the first paragraph of Article 120 of Council Regulation (EC) No $1234 / 2007 "$ ", which was published on $29 / 2 / 2010$ in the Official Journal of the European Union, sets out the definitions of the parameters included in the wine analyses provided by European legislation and, by extension, those included in the analyses conducted by the laboratory of the Regional Center for Plant Protection, Quality and Phytosanitary Control of Kavala. These guidelines contain all the details necessary to cover all cases, and to limit to the 
minimum the cases where interpretative or methodological clarifications are required.

According to this text, Density is classically defined as "the quotient of the mass of a certain volume of wine (or must) by volume, at a temperature of $20^{\circ} \mathrm{C}$ ", symbolized as $\rho_{20}{ }^{\circ} \mathrm{C}$. The text clarifies the management of wines containing a quantity of carbon dioxide as well as the correction applicable to the action of sulfur dioxide, and issues such as the calibration of the densitometer and other instruments.

Total Wine Solid Residues or Total Dry Extract of Wine are defined as "the total substances which are not volatile under specified physical conditions". It is stressed that the conditions under which the total wine solid residues are determined should cause the least possible deterioration in them. In addition, if the total solid residues are removed from the wine sugars, the remainder is defined as "reduced residue".

Total Acidity is defined as "the sum of the volumetric acids when the $\mathrm{pH}$ of the wine is adjusted to 7 by the addition of a titrated alkaline solution". It is also noted that "total acidity does not include carbon dioxide".

Volatile Acidity is defined by the official wording of the EU as "acids in the acetic acid series that are contained in wines in free form, or in the form of salts."

For measuring $\mathbf{p h}$, the use of a two-electrode $\mathrm{pH}$ meter with an accuracy of at least 0.05 units is mentioned.

Regarding Sorbic Acid, three methods for its determination are mentioned, namely the quantitative method by ultraviolet absorption spectrometry, the quantitative method by gas chromatography, and the trace detection method by thin layer chromatography.

Regulation No 1234/2007 states that the Obtained (by volume) Alcoholic Strength by volume is "the number of volumes of pure alcohol at a temperature of $20^{\circ} \mathrm{C}$ contained in 100 volumes of the product". In the obtained alcoholic strength, if the dynamic (by volume) alcoholic strength - the corresponding amount of pure alcohol volumes (at $20^{\circ} \mathrm{C}$ ) - is added, resulting from the complete fermentation of the sugars contained in 100 volumes of product, this results in Total (by volume) Alcoholic Strength.

In the text for Method International Organization of Vine and Wine (OIV) - MA - AS311 - O1A, it is stated that Residual Sugars consist of total sugars with a free aldehyde or ketone group, and they are determined by their reductive action on an alkaline copper solution.

The OIV - MA - AS323 - O4B method in the methodology of the Analysis of Wine and Must by OIV states that Free Sulphur Dioxide (free sulphur) is defined as the sulphur dioxide present in wine in the following forms: $\mathrm{H}_{2} \mathrm{SO}_{3}, \mathrm{HSO}_{3}{ }^{-}$ , whose equivalent as a function of $\mathrm{ph}$ and temperature is: $\mathrm{H}_{2} \mathrm{SO}_{3} \Leftrightarrow \mathrm{H}^{+}+\mathrm{HSO}_{3}{ }^{-}$, whereas Total Sulphur Dioxide (total sulphur) is defined as the sum of the various forms of sulphur dioxide contained in wine, either in a free state or in the form of compounds.

In addition to the determinations made in the context of the analyses, a number of observations were recorded from a taste test performed for each analysis, as well as a macroscopic examination of the wine and its bottle (if it was bottled). From these data, concerning problem cases detected in the taste test, only five observations were made among the 518 samples over the twelve years, i.e. less than one percentage point $(0.97 \%$ ), which means that more than $99 \%$ of all wines in the area had no taste problem, whether they were sampled from bottles, or from tanks and barrels. Specifically, in three out of five cases, an acidic taste was detected in the wine, while in the fourth case it was stated that the wine sample tested generally had the characteristics of vinegar rather than wine. Finally, in the fifth case, it was noted that an unfavorable bitter taste was detected in the examined sample. On a chronological basis, it should be noted that two of the five problems occurred in 2013 and another two even earlier than that. Since 2013, only one problem has been identified throughout the area (Table 16).

Table 16. Cases of problems that occurred in the wine tasting sessions

\begin{tabular}{r|l|r|r}
\hline Year & $\begin{array}{l}\text { Problems that occurred in the } \\
\text { wine tasting sessions }\end{array}$ & Cases & $\begin{array}{l}\text { Type } \\
\text { of } \\
\text { wine }\end{array}$ \\
\hline 2011 & «Unfavorable bitter taste» & 1 & $\begin{array}{r}\text { White } \\
\text { dry } \\
\text { wine } \\
\text { Red } \\
\text { dry }\end{array}$ \\
2012 & «Acid taste» & 1 & $\begin{array}{r}\text { Whine } \\
\text { White } \\
\text { dry } \\
\text { wine }\end{array}$ \\
& «Acid taste» & 1 & $\begin{array}{r}\text { White } \\
\text { dry } \\
\text { wine } \\
\text { Red } \\
\text { dry }\end{array}$ \\
& «Acid taste» & 1 & $\begin{array}{r}\text { wine } \\
\hline\end{array}$ \\
& «Characteristics of vinegar & & \\
\hline & instead of wine» & & \\
\hline
\end{tabular}

Regarding the macroscopic observations, the wine samples showed up 13 problematic cases, in equal numbers of samples, i.e. in $2.51 \%$ of all the samples. This implies that the wine samples in the area that was tested and examined by the analyses showed that the area's wines (assuming that the sampling took place as defined by the competent Ministry of Rural Development \& Food) were problem-free at a rate of $97.49 \%$, regarding the macroscopic control. Of the 13 observations recorded, four concern poor cork quality, one concerns brown coloration of the wine, another indicated that the wine did not show the required durability when exposed to air, while the other seven cases concern the presence of crystals in the wine or sediment residue in the bottle. As stated in the previous section concerning the taste test, most of the observations here were also noticed in the older samples, since only two out of the 13 cases were recorded after 2013, by the staff performing the analyses and control checks (Table 17).

Table 17. Problems detected from the macroscopic observations

\begin{tabular}{c|l|r|r}
\hline Year & $\begin{array}{l}\text { Problems that occurred in the } \\
\text { macroscopic observations }\end{array}$ & Cases & $\begin{array}{l}\text { Type } \\
\text { of } \\
\text { wine }\end{array}$ \\
\hline 2010 & $\begin{array}{l}\text { Appearance of white crystals in } \\
\text { the bottle forming dregs or } \\
\text { sediment }\end{array}$ & 1 & $\begin{array}{r}\text { White } \\
\text { dry } \\
\text { wine } \\
\text { Appearance of white crystals in } \\
\text { the bottle forming dregs or } \\
\text { sediment } \\
\text { Brown grains in sediment form } \\
\text { in the bottle }\end{array}$ \\
$\begin{array}{l}\text { dry } \\
\text { wine } \\
\text { White } \\
\text { dry } \\
\text { wine }\end{array}$
\end{tabular}




\begin{tabular}{|c|c|c|c|}
\hline 2010 & $\begin{array}{l}\text { Brown grains in sediment form } \\
\text { in the bottle }\end{array}$ & 1 & $\begin{array}{r}\text { Rose } \\
\text { dry } \\
\text { wine }\end{array}$ \\
\hline 010 & $\begin{array}{l}\text { White crystals (possibly tartaric } \\
\text { acid) and red grains in the bottle }\end{array}$ & 1 & $\begin{array}{r}\text { White } \\
\text { dry } \\
\text { wine }\end{array}$ \\
\hline 011 & $\begin{array}{l}\text { No resistance when exposed to } \\
\text { air }\end{array}$ & 1 & $\begin{array}{r}\text { White } \\
\text { dry } \\
\text { wine }\end{array}$ \\
\hline 012 & Bad quality of cork & 1 & $\begin{array}{r}\text { Rose } \\
\text { dry } \\
\text { wine }\end{array}$ \\
\hline 012 & Bad quality of cork & 1 & $\begin{array}{r}\text { White } \\
\text { dry } \\
\text { wine }\end{array}$ \\
\hline 012 & Bad quality of cork & 1 & $\begin{array}{r}\text { White } \\
\text { dry } \\
\text { wine }\end{array}$ \\
\hline 012 & Bad quality of cork & 1 & $\begin{array}{r}\text { Red } \\
\text { dry } \\
\text { wine }\end{array}$ \\
\hline 013 & $\begin{array}{l}\text { Appearance of white crystals in } \\
\text { the wine }\end{array}$ & 1 & $\begin{array}{r}\text { Red } \\
\text { semi } \\
- \\
\text { sweet }\end{array}$ \\
\hline 016 & $\begin{array}{l}\text { Considerable quantity of dregs } \\
\text { or sediment in the bottle }\end{array}$ & 1 & $\begin{array}{r}\text { Red } \\
\text { dry } \\
\text { wine }\end{array}$ \\
\hline 2016 & Brown colour & 1 & $\begin{array}{r}\text { Red } \\
\text { dry } \\
\text { wine }\end{array}$ \\
\hline
\end{tabular}

Summing up the problems encountered in both the taste tests and the macroscopic control, since they coincide among the same samples, both from the taste tests and the macroscopic control, the existence of problems is noted in just 15 samples, at a rate of $2.9 \%$. Once again, the findings point to wine samples which were checked and found to be problem-free at a rate of $97.1 \%$.

In addition to the observations made in the macroscopic and taste tests over the past 12 years, from 2008 to 2019 , the results of the analyses also record some observations where an attempt was made to code them, in terms of their content, into three categories for practical reasons. These observations relate to the results of the analyses carried out on the samples and are therefore considered part of the results of the quality control analyses. These categories are as follows:

- Cases where, after the analyses were carried out, a mismatch of the wine with the label was identified, and there was a need to correct the label,

- Cases of value, set for wine, as it relates to each case, such as, e.g., cases where the alcoholic strength or volatile acidity or wine sugars were outside the prescribed limits as laid down by the legislation for each type of wine, and

- Cases where an excess of preservatives were found in the wine.

In all certainty, the gravity of all the above-mentioned cases is not the same, and it is for this reason that it was chosen to classify them, so that these observations are recorded together with the results of the analyses of the wine samples, in order to draw appropriate conclusions.
For the first category, observations were identified in 44 samples, where either a deviation from the measured value was recorded e.g. in the alcoholic strength, from the value indicated on the label, or where, due to the value specified for e.g. wine sugars, the wine has to change category, from dry to semi-dry, or from semi-dry to semi-sweet. This is the most serious case recorded in this classification. Furthermore, among the 44 cases reported, this number has been significantly reduced in recent years, most likely because winemakers have made their own efforts towards selfimprovement; thus, post-2013, such cases are drastically reduced.

The second case relates to sixteen (16) cases which related to (usually minor) excesses in the limits of the wine parameters, based on the measurements made in the analyses.

Finally, the third category constitutes perhaps the most serious case, since an excess in the rates of preservatives used makes all foodstuff unsafe. It should of course be highlighted that this category contained very few cases, just six in number. Table 18 illustrates the evolution of the above observations over the ten-year time period.

Table 18. Table of observations related to the results of the analyses carried out on the samples, forming part of the results of the quality control analyses

\begin{tabular}{|c|c|c|c|}
\hline & $\begin{array}{l}\text { Cases } \\
\text { where a } \\
\text { mismatch } \\
\text { of the wine } \\
\text { with the } \\
\text { label was } \\
\text { identified } \\
\text { after the } \\
\text { analyses } \\
\text { were } \\
\text { carried out }\end{array}$ & $\begin{array}{l}\text { Cases of } \\
\text { prices } \\
\text { exceeding } \\
\text { the prices } \\
\text { forecasted } \\
\text { for wine }\end{array}$ & $\begin{array}{l}\text { Cases where } \\
\text { an excess of } \\
\text { preservatives } \\
\text { were found } \\
\text { in the wine }\end{array}$ \\
\hline 2008 & 1 & 0 & 0 \\
\hline 2009 & - & - & - \\
\hline 2010 & 9 & 1 & 0 \\
\hline 2011 & 11 & 8 & 0 \\
\hline 2012 & 7 & 2 & 0 \\
\hline 2013 & 11 & 2 & 1 \\
\hline 2014 & 0 & 0 & 1 \\
\hline 2015 & 0 & 0 & 0 \\
\hline 2016 & 1 & 2 & 2 \\
\hline 2017 & 0 & 0 & 2 \\
\hline 2018 & 4 & 1 & 0 \\
\hline 2019 & 0 & 0 & 0 \\
\hline TOTAL & 44 & 16 & 6 \\
\hline $\begin{array}{r}\text { Percentage } \\
(\%) \text { of } \\
\text { total } \\
\text { samples }\end{array}$ & $8.49 \%$ & $3.09 \%$ & $1.16 \%$ \\
\hline
\end{tabular}

The macroscopic tests of the sample wines analysed reveal some interesting details which are not related to the measurements of the analyses and their results. Thus, a further classification of the samples is created: these observations are not related to the tested wine and could have been made irrespective of the analyses. Thus, this category includes cases which are not related to the content of the wine and its qualitative characteristics; they include cases where the wine labeling needs to be corrected: in most cases, it is necessary to change the dimensions of the label or the size of the letterings, or to provide some additional information to allow the use of terms such as 'Tower', 'Estate', 'Vineyards' etc, or to 
simply add some more information on the label, as required by law, which is presently missing. This group of observations clearly does not have the same weight as the previous categories, which fall within the control of the wine parameters as detected in the laboratory analyses, e.g. those concerning the preservative limits. Sixty-five (65) such observations were identified in this context, which, as can be seen in Table 19 below, are eliminated after 2013, mainly due to the fact that the wineries have adopted the conditions imposed by the legislation, and have thus eliminated the need to make any further changes. This proves the importance of experience and familiarity with the truly complex legislation governing wines.

Table 19. Observations relating to the characteristics of the wine label (and not the wine) that were tested in the analyses

\begin{tabular}{r|rr}
\hline & $\begin{array}{l}\text { Cases related to the wine bottle label } \\
\text { (and not the wine itself) among the } \\
\text { wine samples analyzed }\end{array}$ \\
\hline 2008 & & 0 \\
2009 & & - \\
2010 & & 18 \\
2011 & & 8 \\
2012 & & 21 \\
2013 & & 18 \\
2014 & 0 \\
2015 & & 0 \\
2016 & & 0 \\
2017 & & 0 \\
2018 & TOTAL & 0 \\
2019 & 0 \\
\hline Percentage & $\mathbf{6 5}$ \\
(\%) of total & \\
samples &
\end{tabular}

Furthermore, the experience of the staff working on the sample analyses in the competent authority has also highlighted one last aspect: that of compliance or noncompliance of wines carrying the designation of Local Wines, or Protected Geographical Indication, concerning the wine-grape varieties foreseen as being included in the wines in each of these cases. Thus, just nine cases were identified where wines described as PGI were found to be composed of wine-grape varieties that were not foreseen as being included in PGI wines. So these wines cannot be labelled PGI until their varietal composition is corrected, according to the regulations. Likewise, most of these cases were identified in earlier years, and they were subsequently limited for the same reasons mentioned previously. The following Table 20 illustrates this:

Table 20. Table of Cases of Non-Compliance with the Predicted Composition of Local Wines \& Wines with Protected Geographical Indication

\begin{tabular}{l|lr}
\hline & $\begin{array}{l}\text { Cases of non-compliance with the } \\
\text { foreseen composition of Local Wines } \\
\text { \& Wines with Protected Geographical } \\
\text { Indication }\end{array}$ \\
\hline 2008 & & 0 \\
2009 & & - \\
2010 & & 7 \\
2011 & & 0 \\
2012 & & 0 \\
2013 & & 2 \\
2014 &
\end{tabular}

\begin{tabular}{r|r}
2015 & 0 \\
2016 & 0 \\
2017 & 0 \\
2018 & 0 \\
2019 & 0 \\
TOTAL & $\mathbf{9}$ \\
\hline Percentage & $\mathbf{1 . 7 4} \%$ \\
(\%) of total & \\
samples & \\
\hline
\end{tabular}

Geographical Discrimination of dry white wines for the three different wine groups (PGI Serres, PGI Drama, PGI Paggaio)

The initial MANOVA is significant, as the following indexes show, Pillai's Trace $=0,361 \quad(\mathrm{~F}=5,173$, pvalue $=0,001<0,05)$ and Wilk's Lambda $=0,670(\mathrm{~F}=5,181$, $\mathrm{p}$ value $=0,001<0,05)$, which shows a significant multivariate effect of the different characteristics on the geographical origin of the dry white wines. The significant $\mathrm{p}$-value $<0,05$ and non-significant characteristics, in determining the differences between areas, at the 5\% level of significance, are presented in Table 21, below:

Table 21. The significant characteristics of the MANOVA analysis, in white dry PGI wines.

\begin{tabular}{|l|r|r}
\hline & \multicolumn{1}{|c|}{$\mathrm{F}$} & \multicolumn{1}{c}{$\mathrm{p}$-value } \\
\hline Total Alcoholic Strength & 0,829 & 0,438 \\
\hline Actual Alcoholic Strength & 0,817 & 0,443 \\
\hline Total Acidity & 8,027 & 0,000 \\
\hline Volatile Acidity & 1,355 & 0,260 \\
\hline $\mathrm{pH}$ & 13,481 & 0,000 \\
\hline Density & 3,719 & 0,026 \\
\hline Total Solid Residue & 2,104 & 0,125 \\
\hline Residual Sugars & 16,954 & 0,000 \\
\hline
\end{tabular}

Subsequently, the four significant characteristics were subjected to Linear Discrimination Analysis (LDA) in order to find out if they can discriminate the origin of the dry white wines in the three different areas. Results showed that two statistically significant discriminant functions are formed (Wilk's Lambda $=0,711, \quad \mathrm{X}^{2}=65,619, \quad \mathrm{df}=8, \quad \mathrm{p}$ value $=0,001<0,05$ for the first, Wilk's Lambda $=0,895$, $\mathrm{X}^{2}=21,266, \mathrm{df}=3, \mathrm{p}$-value $=0,001<0,05$ for the second). A significant value of Wilk's Lambda index shows that the discriminant function is crucial for the differentiation of the investigated groups. Testing of the homogeneity of variances (Box's $M$ index) is non-significant at the 5\% significance level $(33,388, \mathrm{~F}=1,545$, $\mathrm{p}$-value $=0,057>0,05)$, indicating the existence of homogeneity of the variances of the samples, for each area. The first discriminant function accounts for the $68,9 \%$ of total dispersion and the second discriminant function accounts for $30,1 \%$ of total dispersion. All three discriminant functions account for the $99 \%$ of the total dispersion, a percentage which is extremely good. Next figure (Fig. 4) shows that the three areas do not differentiate very well. However, there seems to be a clear discrimination of the mean values of the samples. More specifically, the first discriminant function differentiates the PGIs of Drama, while the second discriminant function seems to differentiate the samples of Paggaio. The characteristics (independent variables) that are included in each one of the functions are presented to Table 22, below:

Table 22. The independent variables which create the discriminant functions for the dry white wines. 
Discriminant Function

\begin{tabular}{lr|r} 
& \multicolumn{3}{c}{ Discriminant Function } \\
& 1 & \multicolumn{1}{c}{2} \\
\hline Residual Sugars & $0,793^{*}$ & 0,320 \\
\hline $\mathrm{pH}$ & $-0,627^{*}$ & 0,563 \\
\hline Total Acidity & $0,558^{*}$ & 0,136 \\
\hline Density & 0,255 & $-0,429^{*}$ \\
\hline
\end{tabular}

Table 23 shows the classification results using both the original and the cross-validation methods. The overall correct classification rate was $72,1 \%$, using the original and $69,5 \%$ using the cross validated method.

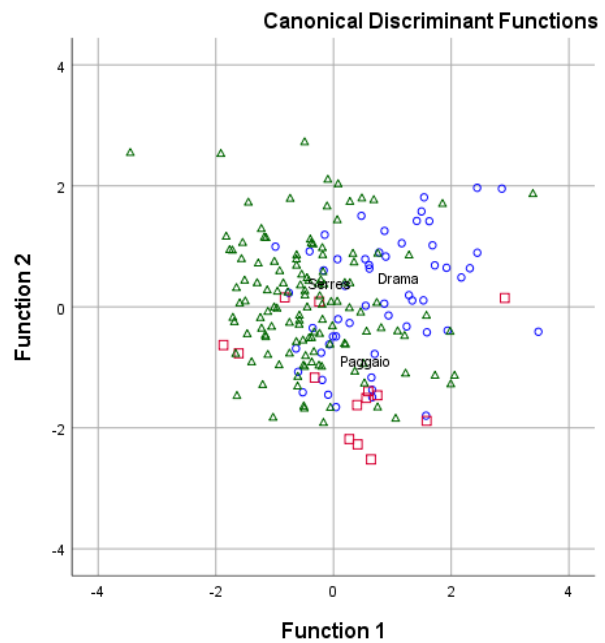

Region

- Drama

$\triangle$ Paggaio

Fig. 4. The discrimination of the geographical origin of the dry white wines with respect to their characteristics

Table 23. Classification results of the dry white wines with respect to their characteristics

\section{Classification Results ${ }^{\mathrm{a}, \mathrm{c}}$}

Predicted Group

Membership

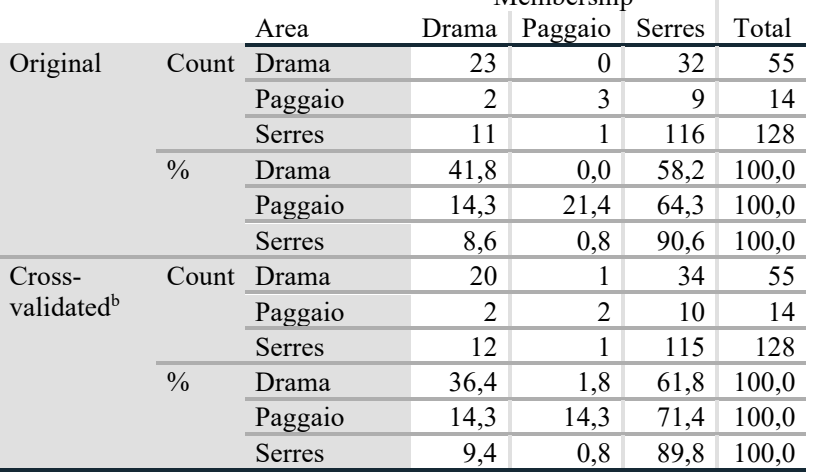

a. $72,1 \%$ of original grouped cases are correctly classified.

b. Cross validation is done only for those cases in the analysis. In cross validation, each case is classified by the functions derived from all cases other than that case.

c. $69,5 \%$ of cross-validated grouped cases correctly classified.

The samples of PGI Serres have the highest classification rate $(90,6 \%)$.

\section{Geographical Discrimination of dry red wines for the three different wine groups (PGI Serres, PGI Drama, PGI Paggaio)}

The initial MANOVA is significant, as the following indexes show: Pillai's Trace $=0,415(\mathrm{~F}=2,395, \mathrm{p}$-value $=0,001<0,05)$ and Wilk's Lambda $=0,640(\mathrm{~F}=2,448$, $\mathrm{p}$-value $=0,001<0,05)$, which shows a significant multivariate effect of the different characteristics on the geographical origin of the dry red wines. The significant $(\mathrm{p}$-value $<0,05)$ and non-significant characteristics, in determining the differences between areas at the $5 \%$ level of significance, are presented in Table 24, below:

Table 24. The significant characteristics of the MANOVA analysis, in red dry PGI wines.

\begin{tabular}{|l|r|r}
\hline Total Alcoholic Strength & F & p-value \\
\hline Actual Alcoholic Strength & 6,783 & 0,000 \\
\hline Total Acidity & 6,452 & 0,000 \\
\hline Volatile Acidity & 0,947 & 0,451 \\
\hline pH & 2,531 & 0,030 \\
\hline Density & 0,496 & 0,779 \\
\hline Total Solid Residue & 3,997 & 0,002 \\
\hline Residual Sugars & 3,906 & 0,002 \\
\hline
\end{tabular}

Subsequently, the four significant characteristics were subjected to Linear Discrimination Analysis (LDA) in order to find out if they can discriminate the origin of the dry red wines in the three different areas. Results showed that two statistically significant discriminant functions are formed (Wilk's Lambda $=0,775, \quad X^{2}=45,504, \quad d f=12, \quad p-$ value $=0,001<0,05$ for the first, and Wilk's Lambda $=0,921$, $\mathrm{X}^{2}=14,676, \mathrm{df}=5, \mathrm{p}$-value $=0,001<0,05$ for the second). A significant value of Wilk's Lambda index shows that the discriminant function is crucial for the differentiation of the investigated groups. Testing of the homogeneity of variances (Box's $M$ index) is non-significant at the 5\% significance level $(35,841, \mathrm{~F}=1,721$, $\mathrm{p}$-value $=0,054>0,05)$, indicating the existence of homogeneity of the variances of the samples, for each area (Fig. 5). The first discriminant function accounts for $68,7 \%$ of total dispersion and the second discriminant function accounts for $30 \%$ of total dispersion. All three discriminant functions account for the $98,7 \%$ of the total dispersion, a percentage which is extremely good. The characteristics (independent variables) that are included in each one of the functions are presented in Table 25.

Table 25. The independent variables which create the discriminant functions for the dry red wines

Discriminant Function

\begin{tabular}{lr|r} 
& 1 & \multicolumn{1}{l}{2} \\
\hline Total Alcoholic Strength & $0,881^{*}$ & $-0,215$ \\
\hline Actual Alcoholic Strength & $0,847^{*}$ & $-0,283$ \\
\hline Residual Sugars & 0,310 & $0,790^{*}$ \\
\hline Volatile Acidity & $-0,125$ & $0,760^{*}$ \\
\hline Density & 0,214 & $0,403^{*}$ \\
\hline Total Solid Residue & 0,318 & $0,397^{*}$ \\
\hline
\end{tabular}

Table 26 shows the classification results using both the original and the cross-validation methods. The overall correct classification rate was $68,6 \%$, using the original and $65,4 \%$ using the cross-validated method. 


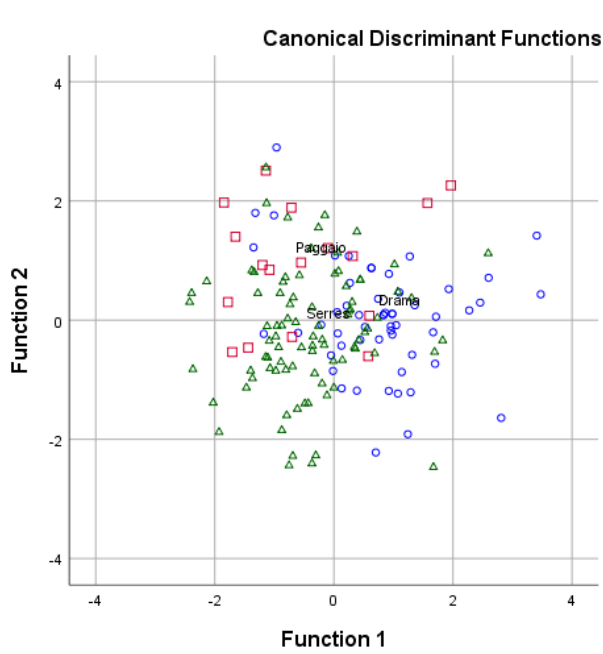

Region

- Drama $\square$ Paggaio

Fig 5. The discrimination of the geographical origin of the dry red wines with respect to their characteristics

Table 26. Classification results of the dry red wines with respect to their characteristics

Classification Results ${ }^{\mathrm{a}, \mathrm{c}}$

Predicted Group

Membership

\begin{tabular}{|c|c|c|c|c|c|c|}
\hline & \multirow{2}{*}{\multicolumn{4}{|c|}{$\begin{array}{l}\text { Predicted Group } \\
\text { Membership }\end{array}$}} & \multirow[b]{4}{*}{ Total } \\
\hline & & & & & & \\
\hline & & \multirow[b]{2}{*}{ Area } & Dram & Paggai & Serre & \\
\hline & & & $\mathrm{a}$ & & & \\
\hline \multirow[t]{6}{*}{ Original } & \multirow{3}{*}{$\begin{array}{l}\text { Coun } \\
t\end{array}$} & Drama & 33 & 2 & 20 & 55 \\
\hline & & $\begin{array}{l}\text { Paggai } \\
\text { o }\end{array}$ & 3 & 3 & 11 & 17 \\
\hline & & Serres & 12 & 2 & 73 & 87 \\
\hline & \multirow[t]{3}{*}{$\%$} & Drama & 60,0 & 3,6 & 36,4 & $\begin{array}{r}100, \\
0\end{array}$ \\
\hline & & $\begin{array}{l}\text { Paggai } \\
\text { o }\end{array}$ & 17,6 & 17,6 & 64,7 & $\begin{array}{r}100, \\
0\end{array}$ \\
\hline & & Serres & 13,8 & 2,3 & 83,9 & $\begin{array}{r}100, \\
0\end{array}$ \\
\hline \multirow{6}{*}{$\begin{array}{l}\text { Cross- } \\
\text { validated } \\
\text { b }\end{array}$} & \multirow{3}{*}{$\begin{array}{l}\text { Coun } \\
\mathrm{t}\end{array}$} & Drama & 33 & 3 & 19 & 55 \\
\hline & & $\begin{array}{l}\text { Paggai } \\
\text { o }\end{array}$ & 3 & 0 & 14 & 17 \\
\hline & & Serres & 13 & 3 & 71 & 87 \\
\hline & \multirow[t]{3}{*}{$\%$} & Drama & 60,0 & 5,5 & 34,5 & $\begin{array}{r}100, \\
0\end{array}$ \\
\hline & & $\begin{array}{l}\text { Paggai } \\
\text { o }\end{array}$ & 17,6 & , 0 & 82,4 & $\begin{array}{r}100, \\
0\end{array}$ \\
\hline & & Serres & 14,9 & 3,4 & 81,6 & $\begin{array}{r}100, \\
0 \\
\end{array}$ \\
\hline
\end{tabular}

a. $68,6 \%$ of original grouped cases are correctly classified.

b. Cross-validation is done only for those cases in the analysis. In cross validation, each case is classified by the functions derived from all cases other than that particular case.

c. $65,4 \%$ of cross-validated grouped cases are correctly classified.

The samples of PGI Serres have the highest classification rate $(83,9 \%)$.

\section{ANCOVA Results for each of the dependent variables}

\section{Results regarding Total Alcoholic Strength}

\footnotetext{
${ }^{1}$ In the following Tables and Pictures, the notation is as follows:

TAS: Total Alcoholic Strength $\left(\%\right.$ Vol. $\left.20^{\circ} \mathrm{C}\right)$,

AAS: Obtained Alcoholic Strength $\left(\%\right.$ Vol. $\left.20^{\circ} \mathrm{C}\right)$,

TA: Total Acidity,

VA: Volatile Acidity,

RS: Residual Sugars,
}

The analytical ANCOVA results in the case of the dependent variable Total Alcoholic Strength are presented in the tables and figures in Appendix A. (Table A1 and A2 and Fig. A1) ${ }_{-}^{1}$

From the analysis, it seems that the PGI (Area) factor has a significant effect on Total Alcoholic Strength, when the covariates of Mean Temperature and Mean Relative Humidity are included in the analysis. This means that the three different areas affect the Total Alcoholic Strength $(F(2,101)=4,27, p=0,035<0.05)$. Figure (Fig. 6) shows the main effects graphically.

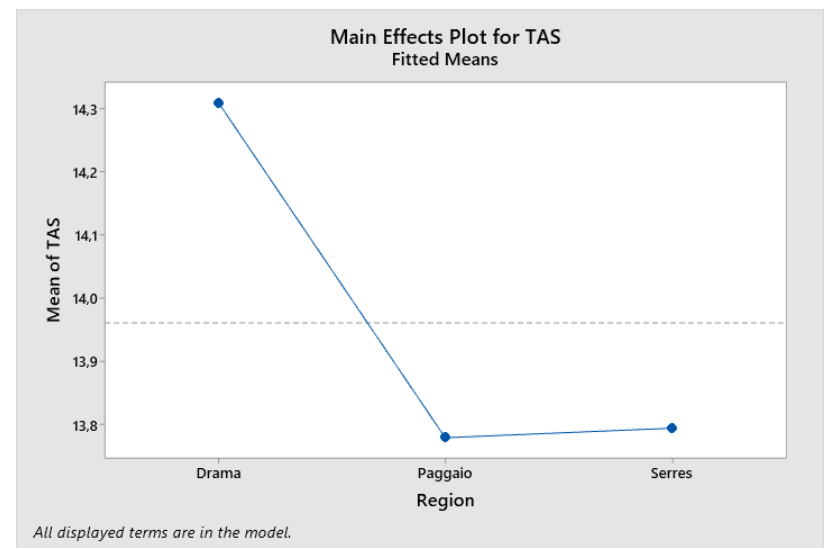

Fig. 6. Mean Values of Total Alcoholic Strength by Area

Fig. 6. shows that PGI Paggaio and PGI Serres wines have the same Total Alcoholic Strength on average in dry red wines, while the Total Alcoholic Strength in PGI Drama, seems to be significant higher. The Lack of Fit test is nonsignificant $(\mathrm{F}(18,112)=1.30 \mathrm{p}=0.115>0.05)$ which means a good overall fit of the model.

The simultaneous effects of both factors and covariates can be presented through contour plots. Because the model has more than two variables, it is clear that all variables cannot be represented in a two-dimensional graph (Montgomery, 2013). For this reason, three separated graphs have been created, for each of the areas.

In the figure below (Fig. 7.) the effect of Mean Relative Humidity is shown in combination with Mean Temperature on Total Alcoholic Strength for each one of the three PGIs. For PGI Drama (Fig. 7A.), the Total Alcoholic Strength seems to be maximized when Mean Relative Humidity values are less than about 55, and at the same time the Mean Temperature of the growing season is above $24^{\circ} \mathrm{C}$. The maximum values of Total Alcoholic Strength are above 14.40 $\left(\%\right.$ Vol. $\left.20^{\circ} \mathrm{C}\right)$. Almost the same are the results regarding PGI Serres (Fig. 7B). However, in this case the extent to which the Total Alcoholic Strength is maximized, seems to reduced, since the values of MRH are little above $50 \%$, while at the same time the temperature is above $24,5^{\circ} \mathrm{C}$. In this case the maximum values of Total Alcoholic Strength are over 13,9 $\left(\%\right.$ Vol. $\left.20^{\circ} \mathrm{C}\right)$. For PGI Paggaio (Fig. 7C) the results appear to be slightly different. Total Alcoholic Strength is maximized for MRH less than $60 \%$ and Mean Temperature of the growing season over $21^{\circ} \mathrm{C}$. In this case the maximum values of Total Alcoholic Strength are over 13,9 (\% Vol. $\left.20^{\circ} \mathrm{C}\right)$.

MT: Mean Temperature, MRH: Mean Relative Humidity, PR: Rain. 


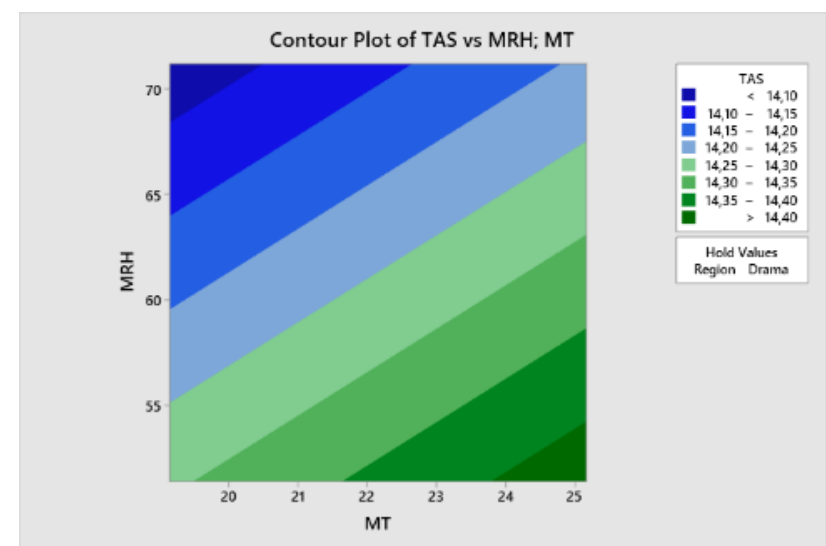

a)

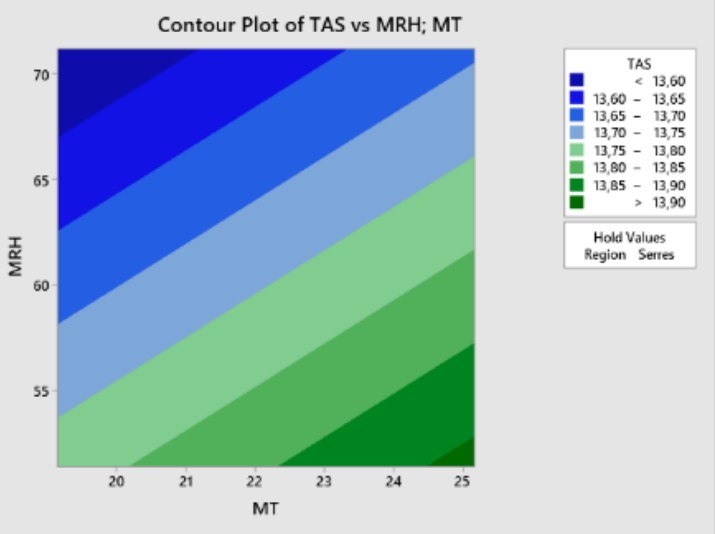

b)

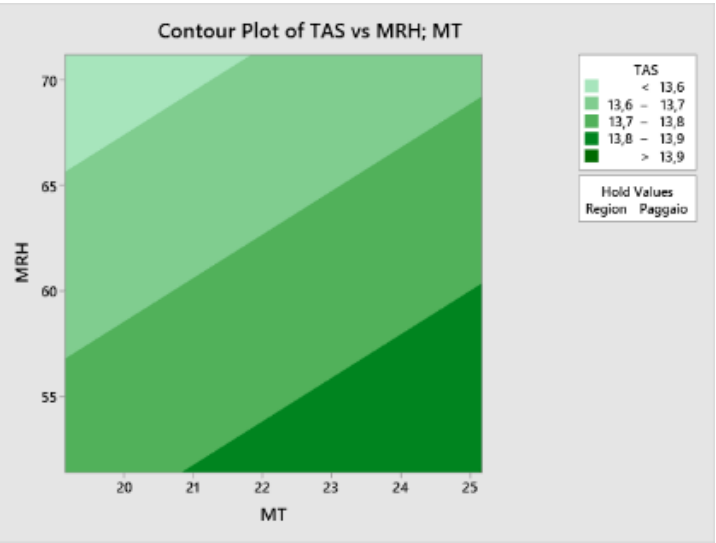

c)

Fig. 7. Contour Plots by area for Total Alcoholic Strength for the combination of Mean Temperature and Mean Relative Humidity.

Based on the above, and with the Response Optimization Process, the maximum and minimum values of Total Alcoholic Strength can determined, for a specific value of each covariate and each category of the factor. In Tables A1 and A2 and Fig. A1 in the Appendix, it seems that the maximum value of Total Alcoholic Strength is $14,433(\%$ Vol. $20^{\circ} \mathrm{C}$ ) and it can be achieved when the Mean Temperature is $25.7^{\circ} \mathrm{C}$, and the Mean Relative Humidity is $51.38 \%$, in the area of Drama. Moreover, the minimum value of Total Alcoholic Strength is 13,537 (\% Vol. $\left.20^{\circ} \mathrm{C}\right)$ and it can be achieved when the Mean Temperature is $19.14^{\circ} \mathrm{C}$, and the Mean Relative Humidity is $71.185 \%$, in the area of Paggaio.

\section{Results regarding Obtained Alcoholic Strength}

The analytical ANCOVA results in the case of the dependent variable Obtained Alcoholic Strength are presented in tables and figures in Appendix A. (Table A3 and A4 and Fig. A2).

From the analysis, it seems that the PGI (Area) factor has a significant effect on Obtained Alcoholic Strength, when the covariates Mean Temperature and Mean Relative Humidity are included in the analysis. This means that the three different areas affect the Obtained Alcoholic Strength $(\mathrm{F}(2,108)=4,92, \mathrm{p}=0,009<0.05)$. Next figure (Fig. 8.) shows the main effects graphically.

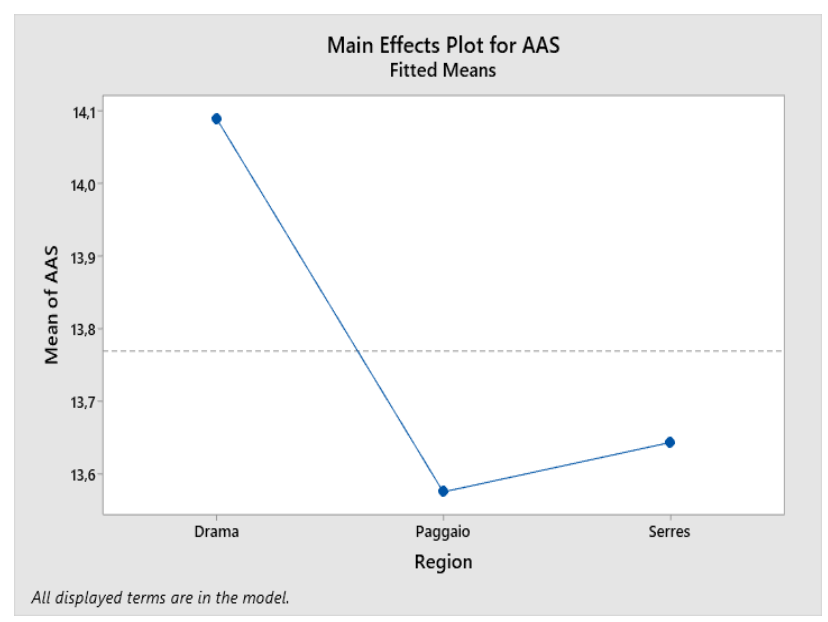

Fig. 8. Mean Values of Obtained Alcoholic Strength by Area

This figure (Fig. 8.) shows that the PGI Paggaio and PGI Serres wines have the same Obtained Alcoholic Strength on average in dry red wines, while the Obtained Alcoholic Strength in PGI Drama, seems to be significantly higher. The Lack of Fit test is non-significant $(F(25,112)=1.09$ $\mathrm{p}=0.376>0.05$ ) which means a good overall fit of the model.

The simultaneous effects of both factors and covariates can be presented through contour plots, at each one of the areas, as is shown in the previous section.

Next figure (Fig. 9.) presents the effect of Mean Relative Humidity in combination with Mean Temperature on Obtained Alcoholic Strength for each one of the three PGIs. For PGI Drama (Fig. 9A), the Obtained Alcoholic Strength seems to be maximized when Mean Relative Humidity values are less than about 55 and at the same time the Mean Temperature of the growing season is above $23,5^{\circ} \mathrm{C}$. The maximum values of Obtained Alcoholic Strength are above $14.15\left(\%\right.$ Vol. $\left.20^{\circ} \mathrm{C}\right)$. Almost the same are the results regarding PGI Serres (Fig. 9B). However, in this case the extent to which the Obtained Alcoholic Strength is maximized, seems to be reduced, since the values of MRH are little above $55 \%$, while at the same time the temperature is above $23^{\circ} \mathrm{C}$. In this case the maximum values of Total Alcoholic Strength are over $13.7\left(\%\right.$ Vol. $\left.20^{\circ} \mathrm{C}\right)$. For PGI Paggaio (Fig. 9C) the results appear to be slightly different. Obtained Alcoholic Strength is maximized for MRH less than $55 \%$ and Mean Temperature of the growing season over $24^{\circ} \mathrm{C}$. In this case the maximum values of Obtained Alcoholic Strength are over $13.65\left(\%\right.$ Vol. $\left.20^{\circ} \mathrm{C}\right)$.

Based on the above, and with the Response Optimization Process, the maximum and minimum values of Obtained Alcoholic Strength can be determined, for a specific value of each covariate and each category of the factor. In Tables A3 and A4 and Fig. A2 in the Appendix, it seems that the maximum value of Obtained Alcoholic Strength is 14,191 (\% Vol. $20^{\circ} \mathrm{C}$ ) and it can be achieved when the Mean Temperature is $25.17^{\circ} \mathrm{C}$, and the Mean Relative Humidity is 
$51.38 \%$, in the area of Drama. Moreover, the minimum value of Obtained Alcoholic Strength is $13,374\left(\%\right.$ Vol. $\left.20^{\circ} \mathrm{C}\right)$ and it can be achieved when the Mean Temperature is $19.14^{\circ} \mathrm{C}$, and the Mean Relative Humidity is $71.185 \%$, in the area of Paggaio.

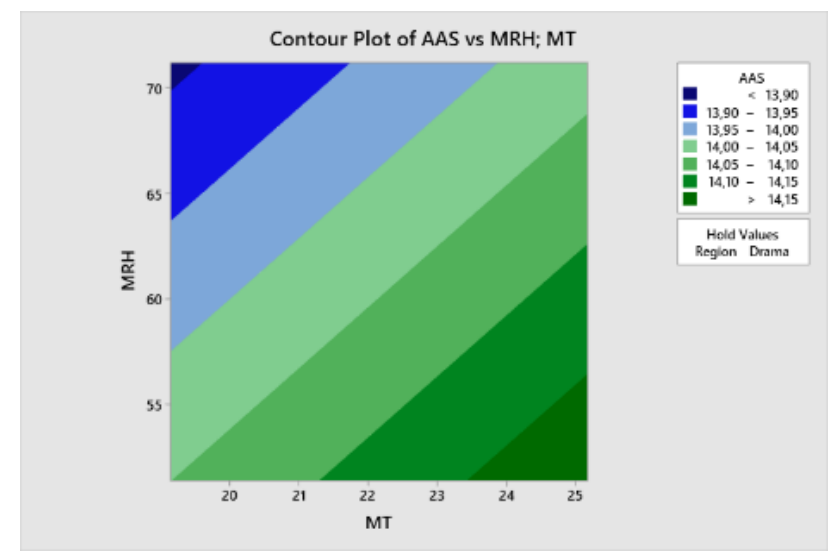

a)

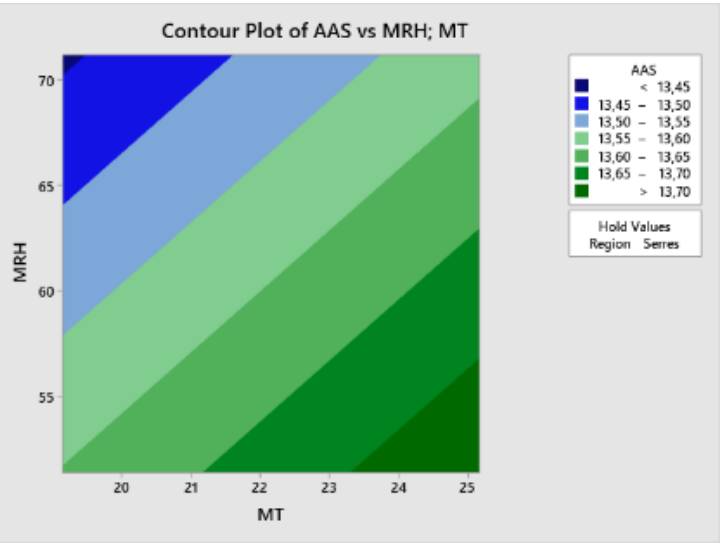

b)

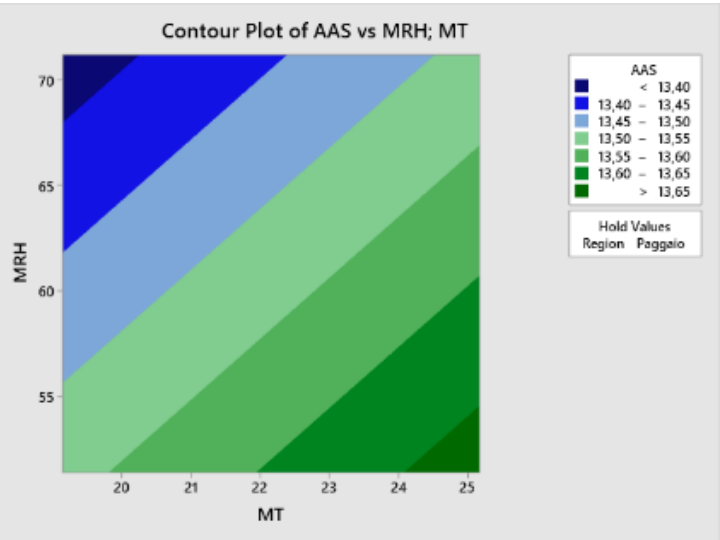

c)

Fig. 9. Contour Plots by area for Obtained Alcoholic Strength (AAS) for the combination of Mean Temperature and Mean Relative Humidity.

\section{Results regarding Total Acidity}

The analytical ANCOVA results in the case of the dependent variable Total Acidity are presented in tables and figures in Appendix A. (Table A5 and A6 and Fig. A3).

From the analysis, it seems that the PGI (Area) factor has a significant effect on Total Acidity, when the covariates Mean Temperature and Mean Relative Humidity are included in the analysis. This means that the three different areas affect the Total Acidity $(\mathrm{F}(2,108)=2,86, \mu \varepsilon \mathrm{p}=0,041<0.05$. $)$. Next figure (Fig. 10)_shows the main effects graphically.

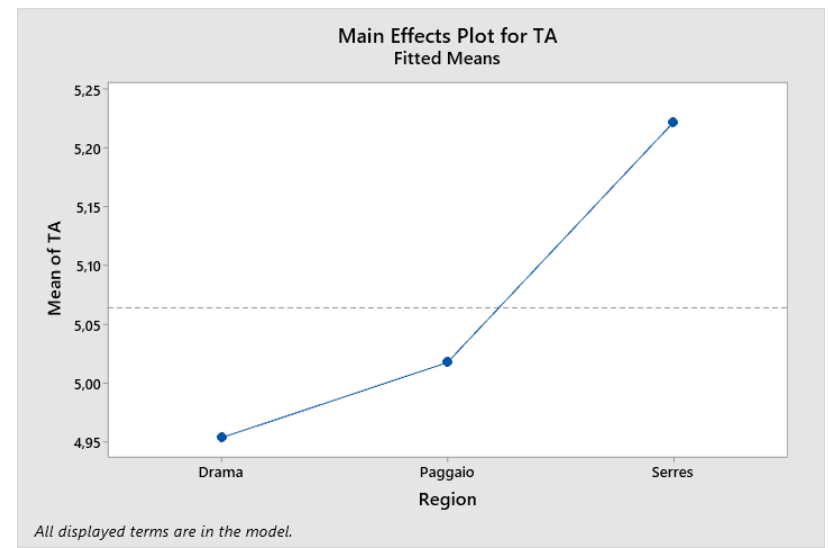

Fig. 10. Mean Values of Total Acidity by area

This figure (Fig. 10) shows that PGI Paggaio and PGI Drama wines have the same Total Acidity on average in dry red wines, while the total acidity in PGI Serres, seems to be significantly higher. The Lack of Fit test is non-significant $(\mathrm{F}(25,112)=1.01 \mathrm{p}=0.463>0.05)$ which means a good overall fit of the model.

The simultaneous effects of both factors and covariates can be presented through contour plots, at each one of the areas, as in the previous sections.

Next figure (Fig. 11.) presents the effect of Mean Relative Humidity in combination with Mean Temperature on Total Acidity for each one of the three PGIs. For PGI Drama (Fig. 11A), the Total Acidity seems to be maximized when Mean Relative Humidity values are less than about $65 \%$ and at the same time the Mean Temperature of the growing season is below $19,5^{\circ} \mathrm{C}$. The maximum values of Total Acidity are above 5.3. Slightly different are the results regarding PGI Serres (Fig. 11B). However, in this case the extent to which Total Acidity is maximized, seems to be increased, since the values of MRH are above $70 \%$, while at the same time the temperature is lower than $20^{\circ} \mathrm{C}$. In this case the maximum values of Total Acidity are over 5.6.

For PGI Paggaio (Fig. 11C) the results appear to be slightly different, especially for the minimum values. Total Acidity is maximized for MRH greater than $70 \%$ and Mean Temperature of the growing season below $20^{\circ} \mathrm{C}$. In this case the maximum values of Total Acidity are over 5.3.

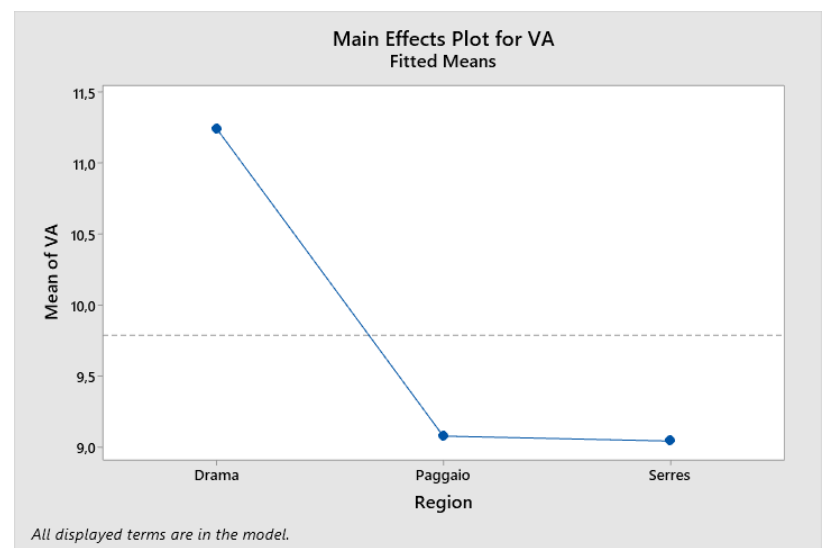

Fig. 12. Mean Values of Volatile Acidity by Area.

Based on the above, and with the Response Optimization process the maximum and minimum values of Total Acidity can be determined, for a specific value of each covariate and each category of the factor. In Tables A5 and A6 and in Fig. $\mathrm{A} 3$ in the Appendix, it seems that the maximum value of Total 
Acidity is 5.6 and it can be achieved when the Mean Temperature is $19.14^{\circ} \mathrm{C}$, and the Mean Relative Humidity is $51.384 \%$, in the area of Serres. Moreover, the minimum value of Total Acidity is 4,754 and it can be achieved when the Mean Temperature is $25.17^{\circ} \mathrm{C}$, and the Mean Relative Humidity is $71.185 \%$, in the area of Drama.

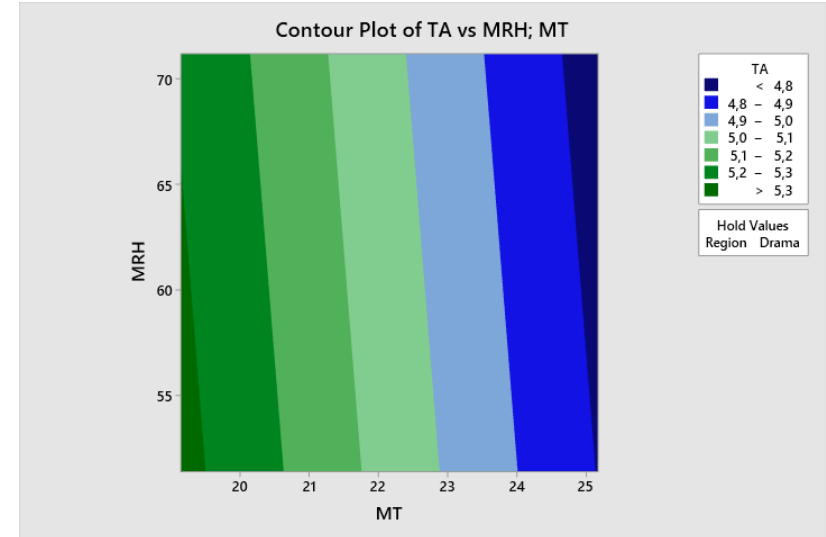

a)

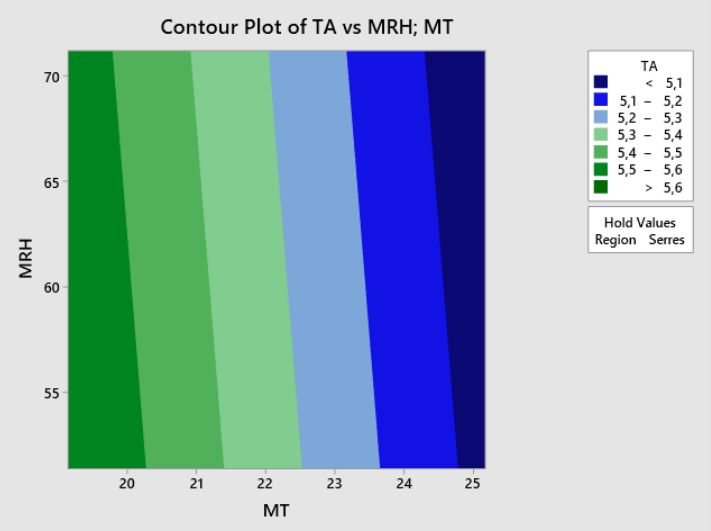

b)

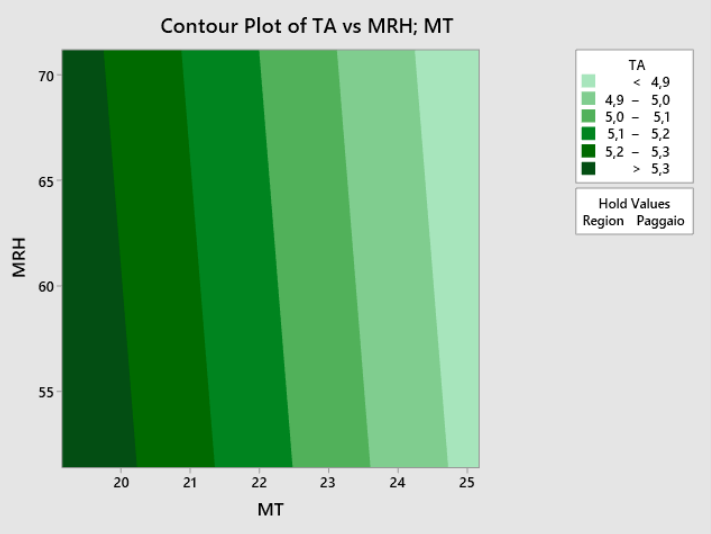

c)

Fig. 11. Contour Plots by Area for Total Acidity (TA) for the combination of Mean Temperature and Mean Relative Humidity.

\section{Results regarding Volatile Acidity}

The analytical ANCOVA results in the case of the dependent variable Volatile Acidity are presented in tables and figures in Appendix A. (Table A7 and A8 and Fig.A4).

From the analysis, it seems that the PGI (Area) factor has a significant effect on Volatile Acidity, when the covariates Mean Temperature and Mean Relative Humidity are included in the analysis. This means that the three different areas affect the Volatile Acidity $(\mathrm{F}(2,108)=7,16, \mathrm{p}=0,001<0.05)$. Next figure (Fig. 12) shows the main effects graphically.
This figure (Fig. 12) shows that PGI Paggaio and PGI Serres wines have the same Volatile Acidity on average in dry red wines, while the Total Acidity in PGI Drama, seems to be significant higher. The Lack of Fit test is non-significant $(\mathrm{F}(25,112)=1.06, \mathrm{p}=0.405>0.05)$ which means a good overall fit of the model.

The simultaneous effects of both factors and covariates can be presented through contour plots, at each one of the areas, as in the previous sections.

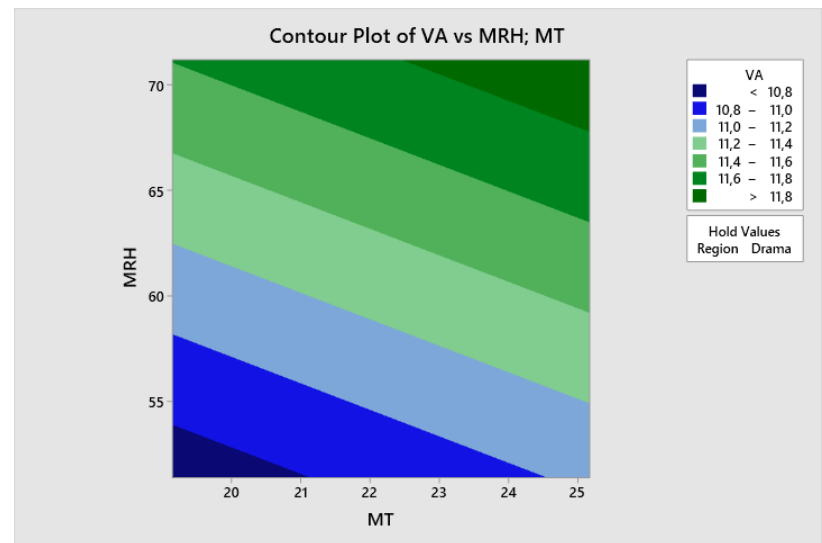

a)

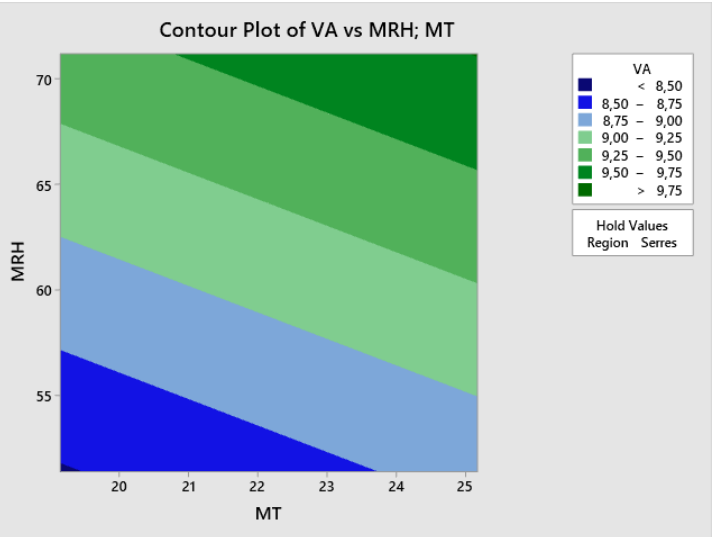

b)

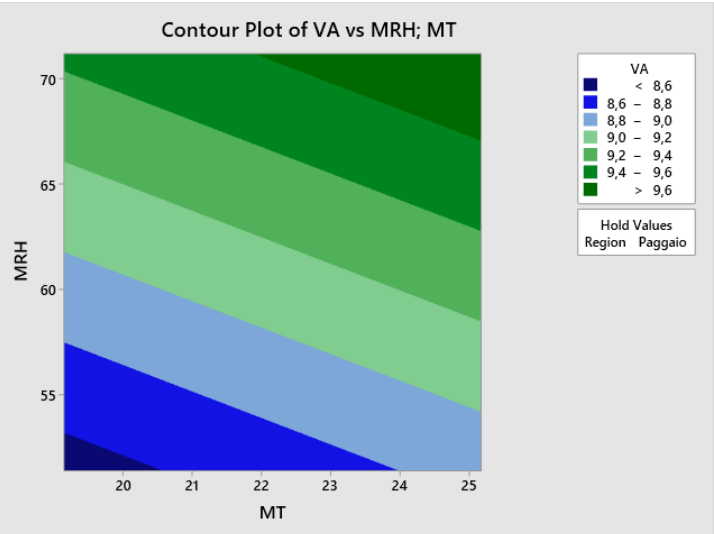

c)

Fig. 13. Contour Plots by Area for Volatile Acidity (VA) for the combination of Mean Temperature and Mean Relative Humidity.

Next figure (Fig. 13) presents the effect of Mean Relative Humidity in combination with Mean Temperature on Volatile Acidity for each one of the three PGIs. For PGI Drama (Fig. 13A), the Volatile Acidity seems to be maximized when Mean Relative Humidity values are greater than about $68 \%$ and at the same time the Mean Temperature of the growing season is above $22,5^{\circ} \mathrm{C}$. The maximum values of Volatile Acidity are above 11.8. Slightly different are the results 
regarding PGI Serres (Fig. 13B). However, in this case the extent, to which Volatile Acidity is maximized, seems to be significantly increased, since the values of $\mathrm{MRH}$ are sufficiently above 65 , while at the same time the temperature is above $21^{\circ} \mathrm{C}$. In this case the maximum values of Volatile Acidity are over 9.75. For PGI Paggaio (Fig. 13C), the results appear to be slightly different, especially for the minimum values. Volatile Acidity is maximized for MRH greater than 67 and Mean Temperature of the growing season over $22^{\circ} \mathrm{C}$. In this case the maximum values of Volatile Acidity are over 9.6.

Based on the above, and with the Response Optimization process the maximum and minimum values of Volatile Acidity can be determined, for a specific value of each covariate and each category of the factor. In Tables A7 and A8 and in Fig. A4 in Appendix A, it seems that the maximum value of Volatile Acidity is 11.96 and it can be achieved when the Mean Temperature is $25.17^{\circ} \mathrm{C}$, and the Mean Relative Humidity is $71.185 \%$, in the area of Drama. Moreover, the minimum value of Volatile Acidity is 8,48 and it can be achieved when the Mean Temperature is $19.14^{\circ} \mathrm{C}$, and the Mean Relative Humidity is $51.388 \%$, in the area of Serres.

\section{Results regarding Residual Sugars}

The analytical ANCOVA results in the case of the dependent variable Residual Sugars are presented in tables and figures in Appendix A. (Table A9 and A10 and Fig. A5).

From the analysis, it seems that the PGI (Area) factor has a significant effect on the quantity of the Residual Sugars, when the covariates Mean Temperature and Mean Relative Humidity are included in the analysis. This means that the three different areas affect the quantity of Residual Sugars $(\mathrm{F}(2,108)=8,15, \mathrm{p}=0,001<0.05)$. Next figure (Fig. 14) shows the main effects graphically.

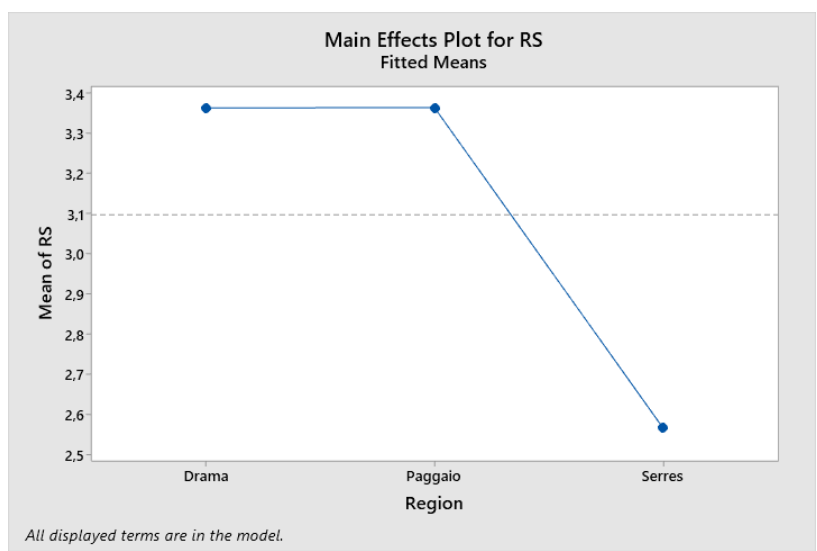

Fig. 14. Mean Values of Residual Sugars by Area.

This figure (Fig. 14) shows that PGI Paggaio and PGI Drama wines have the same quantity of Residual Sugars on average in dry red wines, while the resigual sugars in PGI Serres, seems to be significant lower. The Lack of Fit test is non-significant $(\mathrm{F}(25,112)=2.06 \mathrm{p}=0.06>0.05)$ which means a good overall fit of the model.

The simultaneous effects of both factors and covariates can be presented through contour plots, at each one of the areas, as in previous sections.

Next figure (Fig. 15) presents the effect of Mean Relative Humidity in combination with Mean Temperature on the quantity of Residual Sugars for each one of the three PGIs. For PGI Drama (Fig. 15A), the quantity of Residual Sugars seems to be maximized when Mean Relative Humidity values are less than about $53 \%$ and at the same time the Mean
Temperature of the growing season is above $24^{\circ} \mathrm{C}$. The maximum values of Residual Sugars are above 3.6. Almost the same are the results regarding PGI Serres. (Fig. 15B) with the area of maximization and minimization as almost identical. In this case the maximum values of Residual Sugars are over 2.8 .

For PGI Paggaio (Fig. 15C) the results appear to be the same with the other two areas. In this case the maximum values of Residual Sugars are over 3.6.

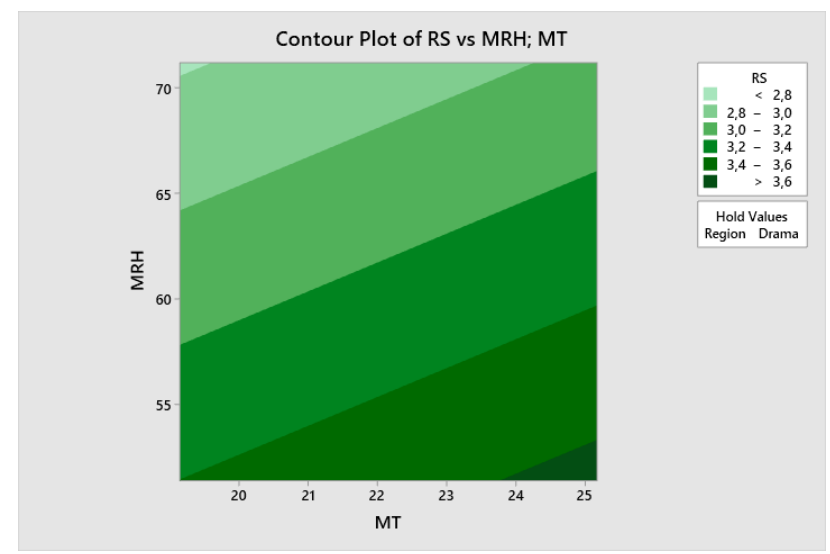

a)

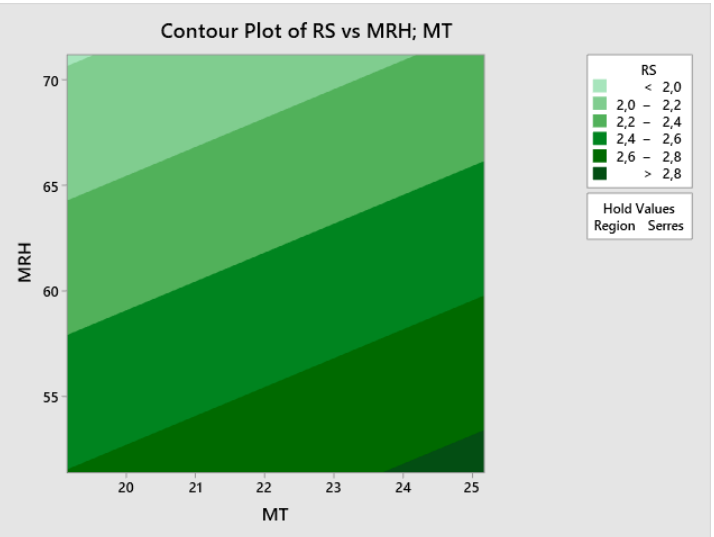

b)

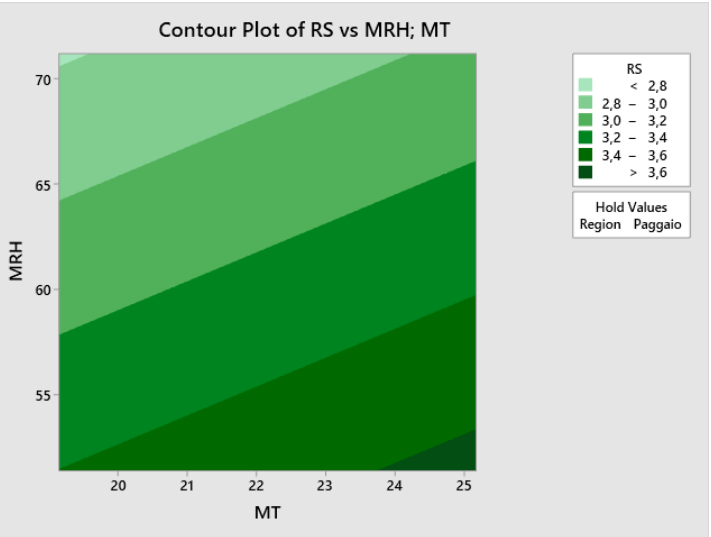

c)

Fig. 15. Contour Plots by Area for the quantity of Residual Sugars (RS) for the combination of Mean Temperature and Mean Relative Humidity.

Based on the above, and with the Response Optimization Process the maximum and minimum values of the quantity of Residual Sugars can be determined, for a specific value of each covariate and each category of the factor. In Tables A9 and A10 and Figure A5 in Appendix A, it seems that the maximum value of Residual Sugars is 3.633 and it can be achieved when the Mean Temperature is $25.17^{\circ} \mathrm{C}$, and the Mean Relative Humidity is $51.388 \%$, in the area of Paggaio. 
Moreover, the minimum value of RS is 1.983 and it can be achieved when the Mean Temperature is $19.14^{\circ} \mathrm{C}$, and the Mean Relative Humidity is $71.185 \%$, in the area of Serres.

\section{Results of Time Series Plots}

\section{A. Total and Obtained Alcoholic Strength}

A1. Mean Temperature of the growing season

Initially, from next figure (Fig. 16) it can be seen that, for almost all the three areas, the lines for both Total and Obtained Alcoholic Strength, seem to be consistent with the corresponding average temperatures of the growing season. For PGI Paggaio, there seems to be a divergence in the years 2010 and 2011. Moreover, for PGI Serres (Fig. 16A) there seems to be a slight indication of a four-year seasonality, as in years 2008, 2012 and 2016 the Mean Temperature was low. This fact seems to have resulted in relatively lower both Total and Obtained Alcoholic Strength values. This possibility, however, requires further investigation in order to draw clearer conclusions.

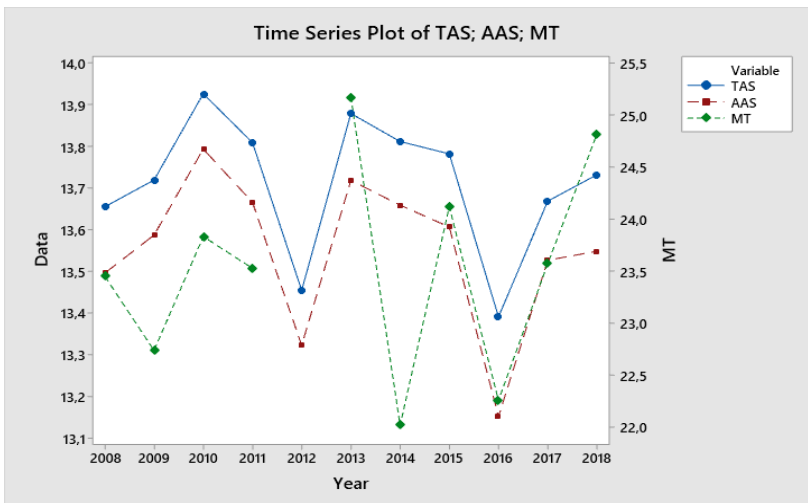

a)

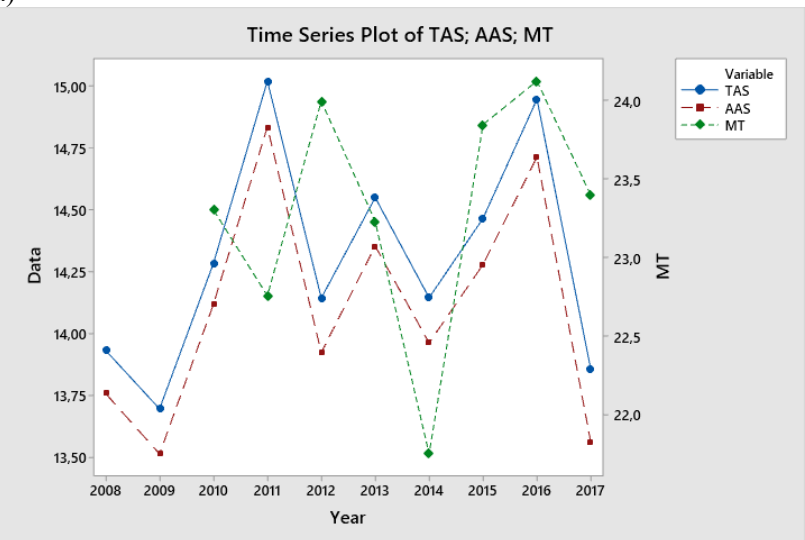

b)

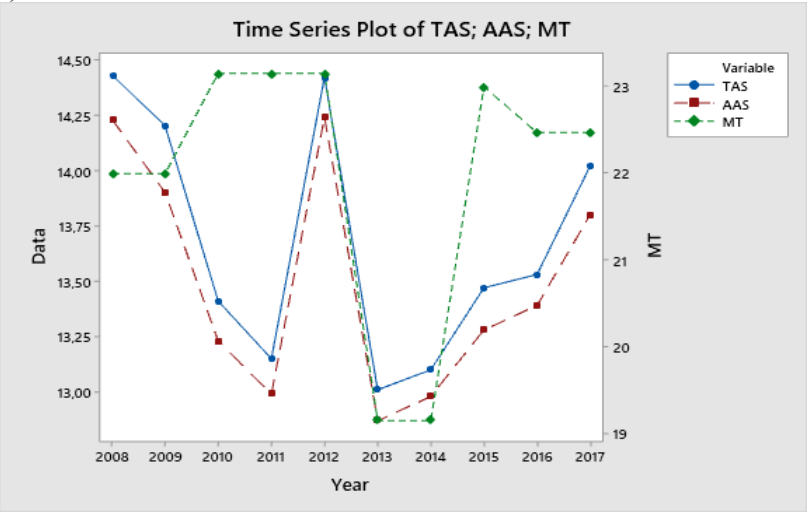

c)

Fig. 16. Time series of Total and Obtained Alcoholic Strength in relation with Mean Temperature of the growing season of three PGIs (A. Serres, B. Drama, C. Paggaio).

\section{A2. Mean Relative Humidity of the growing season}

Next figure (Fig. 17) shows that in the case of Mean Relative Humidity of the growing season, the time series plots of both Total and Obtained Alcoholic Strength seem to be almost the same, with those of Mean Relative Humidity in the area of Serres. (A). A slight divergence seems to exists for PGI Drama (B), for the years 2011 and 2013, while a significant divergence exists for PGI Paggaio (C), for the years 2013 and 2014.

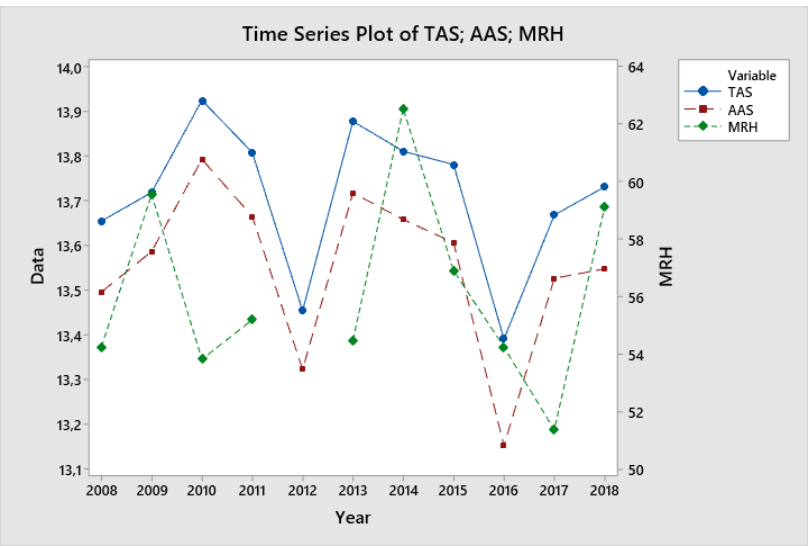

a)

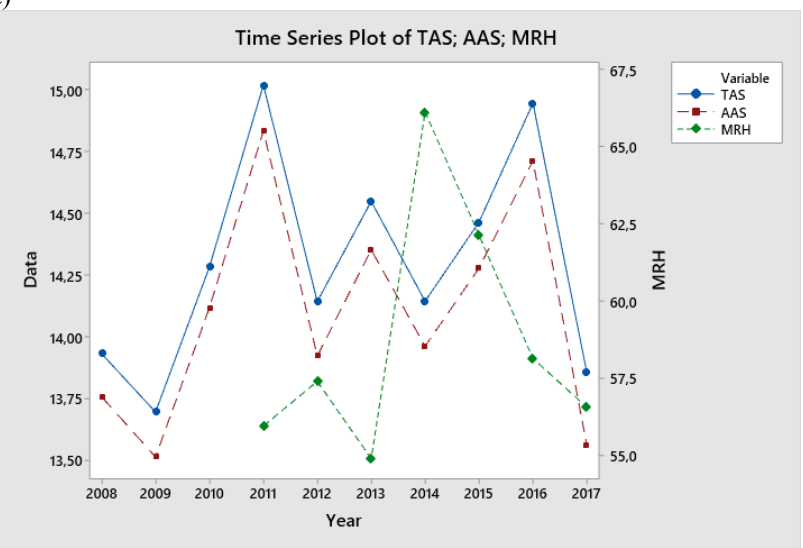

b)

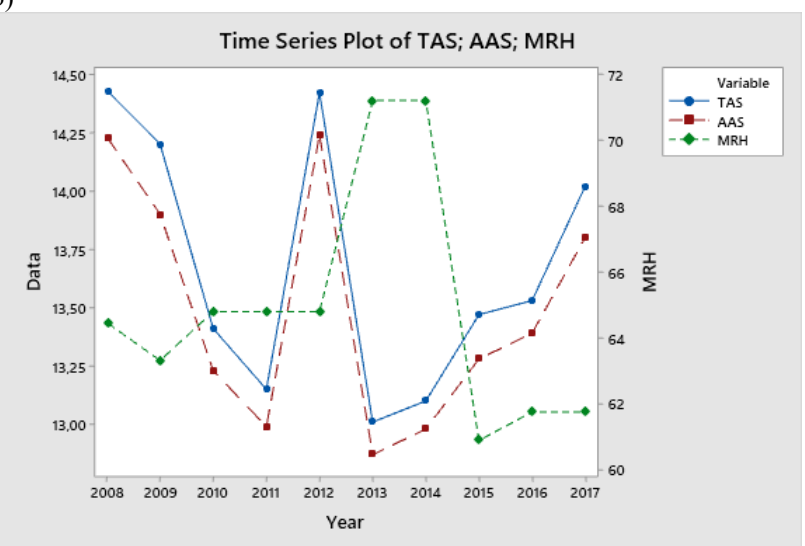

c)

Fig. 17. Time series of Total and Obtained Alcoholic Strength in relation with Mean Relative Humidity of the growing season of three PGIs (A. Serres, B. Drama, C. Paggaio).

\section{A3. Mean Rainfall}

The following time series plots show the Total and the Obtained Alcoholic Strength of the dry red wines of the PGIs of Serres and Paggaio, in combination with the Mean Rainfall height of the harvest year. Next figure (Fig. 18) shows that in the case of rainfall, the time series of both Total and Obtained Alcoholic Strength have the same shape with the time series 
plot of Mean Rainfall, except for the years 2008, 2013 and 2014 only in the area of Paggaio. In general, there is an indication that, on average, high rainfall levels lead to high Total and Obtained Alcohol Strength and vice versa, for both areas.

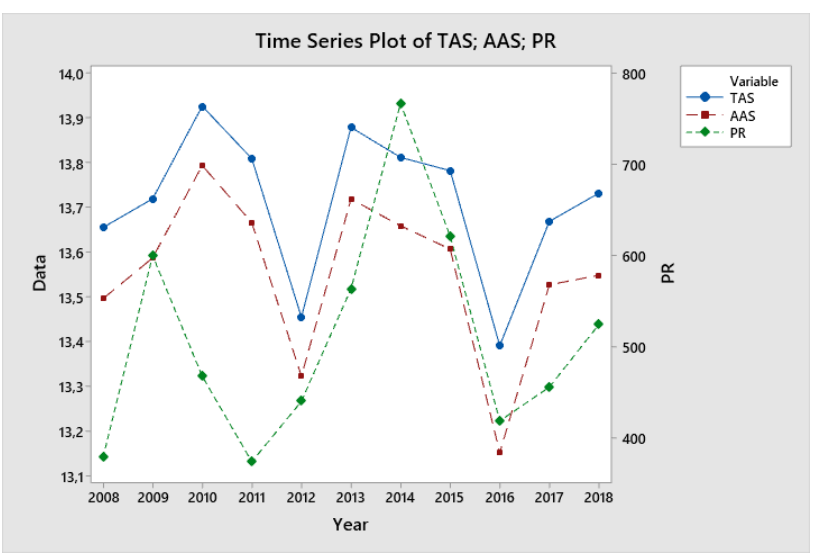

a)

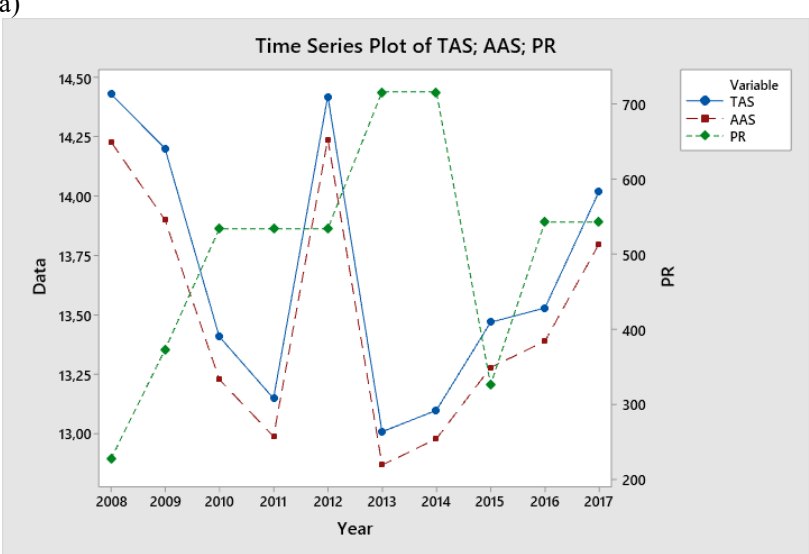

b)

Fig. 18. Time series of Total and Obtained Alcoholic Strength in relation with annual rainfall height for the PGIs of Serres (A) and Paggaio (B).

\section{B. Total and Volatile Acidity}

\section{B1. Mean Temperature of the growing season}

Next figure (Fig. 19) shows the time series plots for Total and Volatile Acidity of dry red wines in relation with the Mean Temperature of the growing season, for the three PGIs. The Total Acidity seems to be steady with a slight decreasing trend and without any correlation with the Mean Temperature.

At this point, and for the following analysis, it is worth mentioning that Total Acidity is not affected by any climatic factor, due to the manipulations that winemakers can sometimes apply, in order to regulate the values of this parameter in wines. On the contrary, the Volatile Acidity seems to have slight diversions in relation to the temperature, and this happens in all three areas. In years with low temperatures in the growing season, a relatively lower Volatile Acidity also seems to emerge.

It is worth noting here, that in all diagrams, which include Total and Volatile Acidity, that the units of Total and Volatile Acidity are different and the two curves appear in the same diagram only for practical reasons, in order to compare them with the temperature (or the relative humidity and precipitation, hereafter). In no case does the diagram provide any indication of a comparison of Volatile Acidity with Total Acidity, or vice versa.

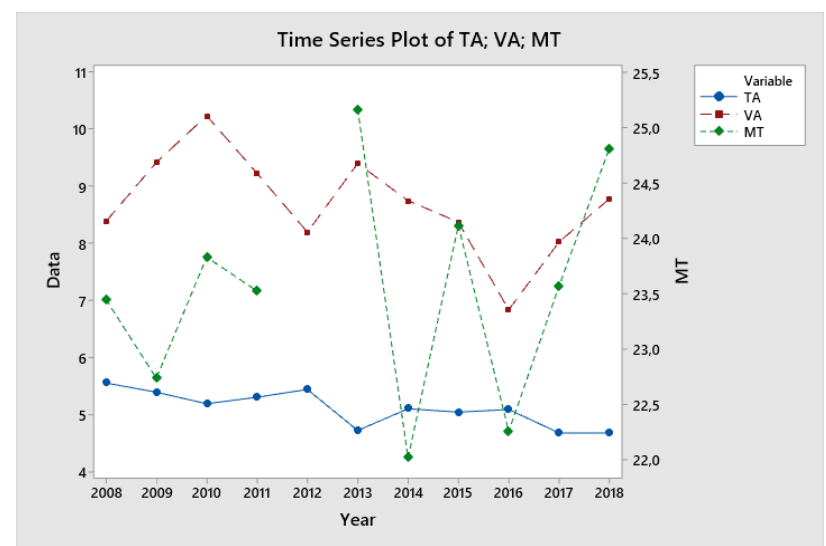

a)

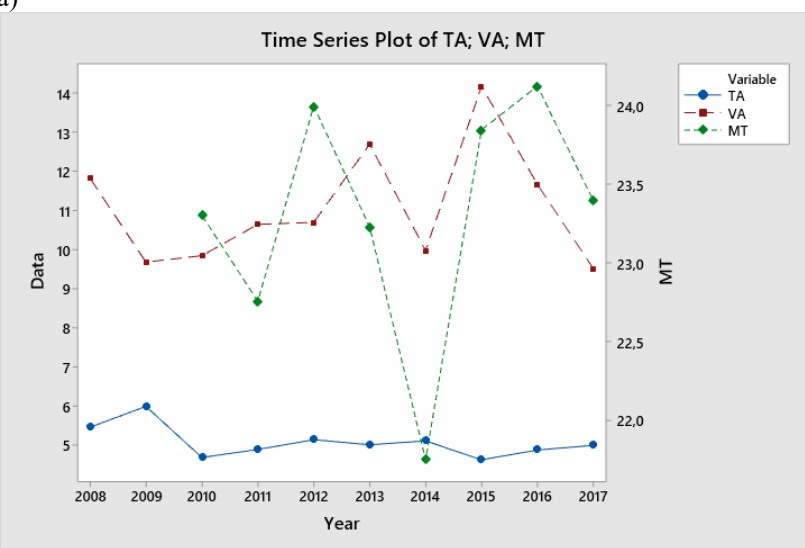

b)

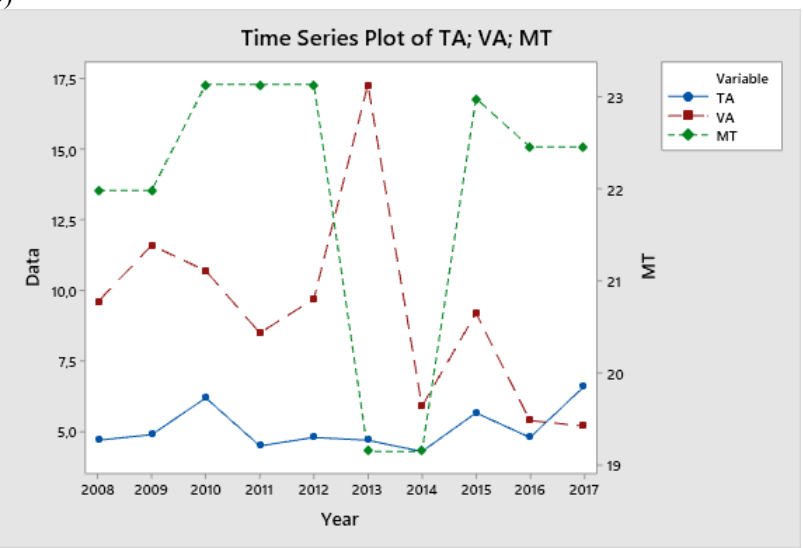

c)

Fig. 19. Time series of Total and Volatile Acidity in relation with Mean Temperature of the growing season of three PGIs (A. Serres, B. Drama, C. Paggaio).

\section{B2. Mean Relative Humidity of the growing season}

Next figure (Fig. 20) shows the time series plots for Total and Volatile Acidity of dry red wines in relation with the Mean Relative Humidity of the growing season, for the three PGIs and in the same period. This figure (Fig. 20) shows that Total Acidity seems to remain relatively stable and unaffected over the years, whereas Volatile Acidity has fluctuated slightly with respect to the average values of relative humidity of the growing season, as in the case with the Mean Temperature, as reported in the previous paragraph. These fluctuations are most intense for Volatile Acidity in PGI Serres (A) and PGI Drama (B), while in PGI Paggaio (C), Volatile Acidity follows to some extent the fluctuations of the humidity of the growing season. There is generally some indication that in years, where a slight average relative humidity is present, lower Volatile Acidity values are also present. 


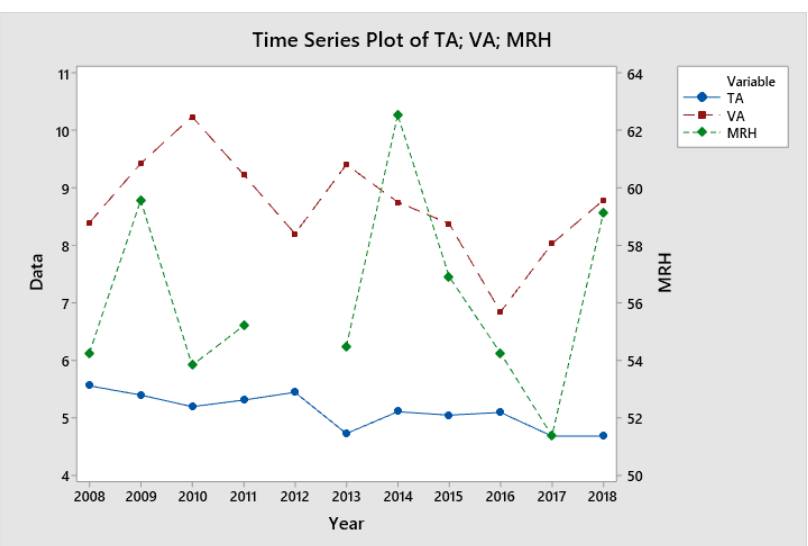

a)

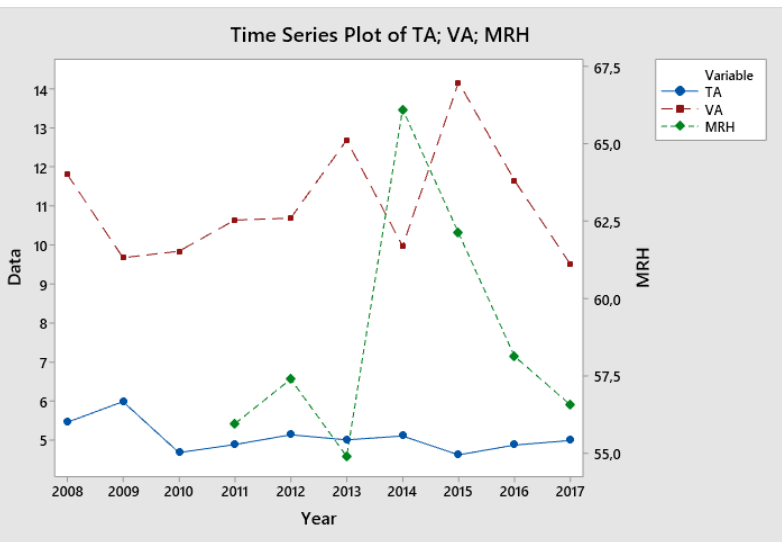

b)

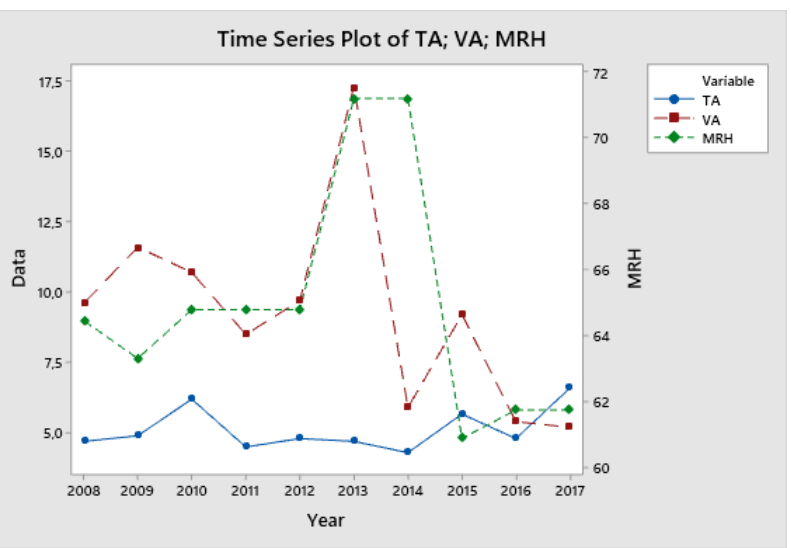

c)

Fig. 20. Time series of Total and Volatile Acidity in relation with Mean Relative Humidity of the growing season of three PGIs (A. Serres, B. Drama, C. Paggaio).

\section{B3. Mean Annual Rainfall height}

The following time series plots show the Total and Volatile Acidity of the dry red wines of the PGIs of Serres (A) and Paggaio (B), in combination with the Mean Rainfall height of the harvest. Next figure (Fig. 21) shows that in general the same form of acidity is shown in the time series as in previous climate data. That is, there seems to be no major change in the values of Total Acidity over the years, despite a very marginal decreasing trend. For Volatile Acidity, a relatively small decrease in the corresponding values also appears, when the annual precipitation is significantly lower.

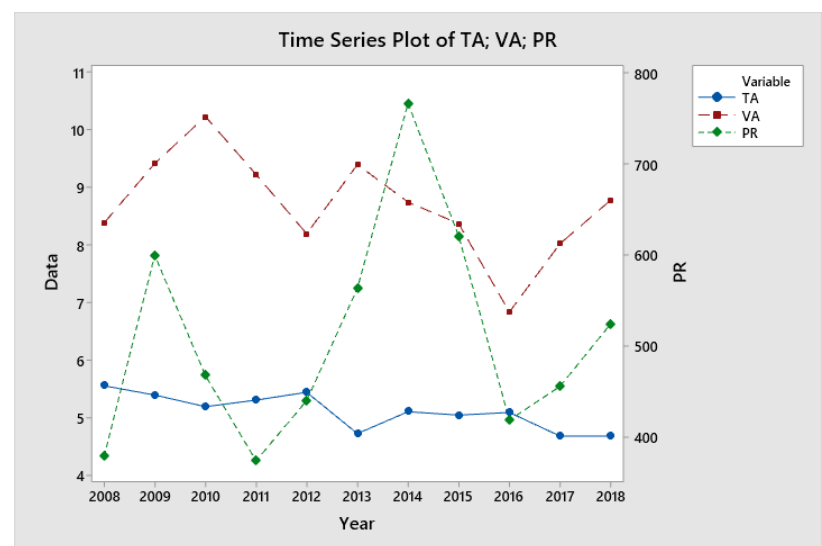

a)

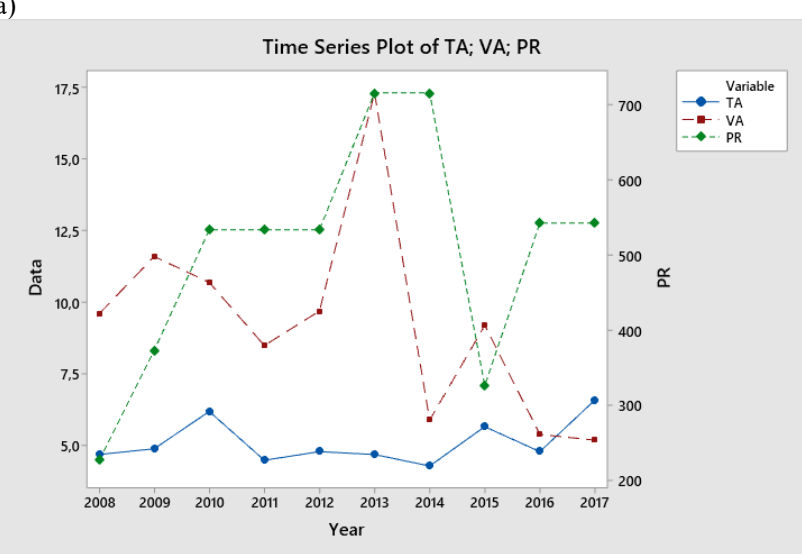

b)

Fig. 21. Time series of Total and Volatile Acidity in relation with Annual Rainfall height for the PGIs of Serres (A) and Paggaio (B).

\section{Residual Sugars}

\section{C1. Mean Temperature of the growing season}

Next figure (Fig. 22) shows the time series plots for Residual Sugars of dry red wines in relation with the Mean Temperature of the growing season, for the three PGIs. As in the previous cases, the two time series plots for PGI Serres (A) and PGI Drama (B) appear to be almost the same, with a divergence in 2013 for PGI Serres. For PGI Paggaio, there is a significant divergence of Residual Sugars relative to the Mean Temperature of the growing season, except in years 2013 and 2014. There also appears to be a slight upward trend in Residual Sugars in all three areas, over the years. This increase appears to be more significant for the area of Drama (B)

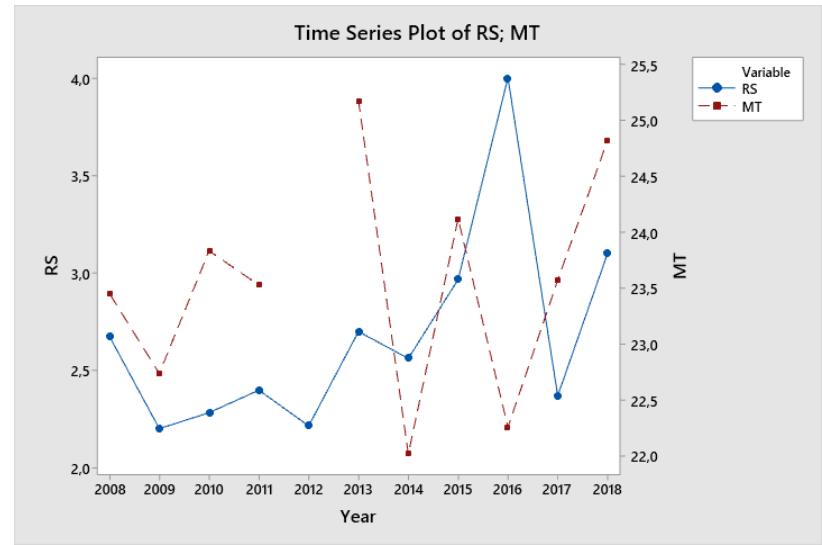

a) 


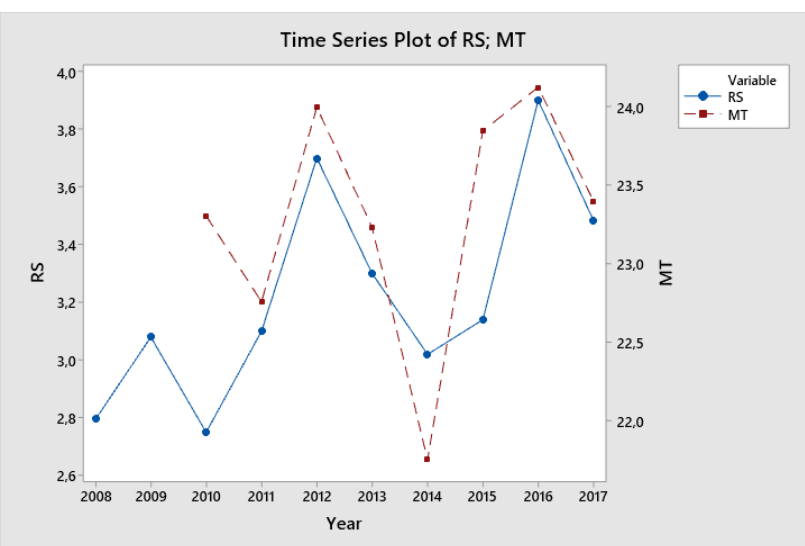

b)

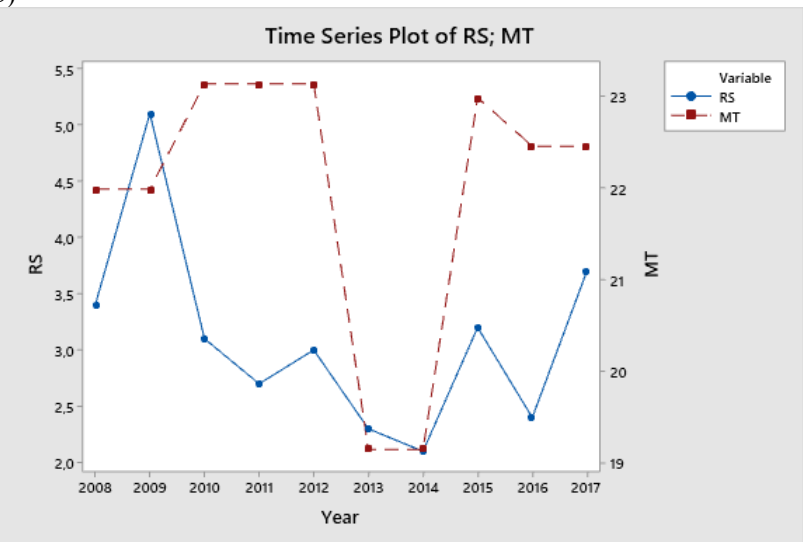

c)

Fig. 22. Time series of Residual Sugars in relation with Mean Temperature of the growing season of three PGIs (A. Serres, B. Drama, C. Paggaio).

\section{C2. Mean Relative Humidity of the growing season}

For the Residual Sugars, we can see (Fig. 23) that in this case too, the time series does not generally follow the Mean Relative Humidity, but it shows the exact opposite for many years. Especially in the years 2014 and 2016 and for PGIs Serres and PGI Drama, the time series of Residual Sugars goes against the Mean Relative Humidity. Specifically, in 2014 while data showed a high Mean Relative Humidity for the growing season, the total Residual Sugars level was low and while in 2016, the data are reversed. For PGI Paggaio, this happened in the years 2013 and 2014.

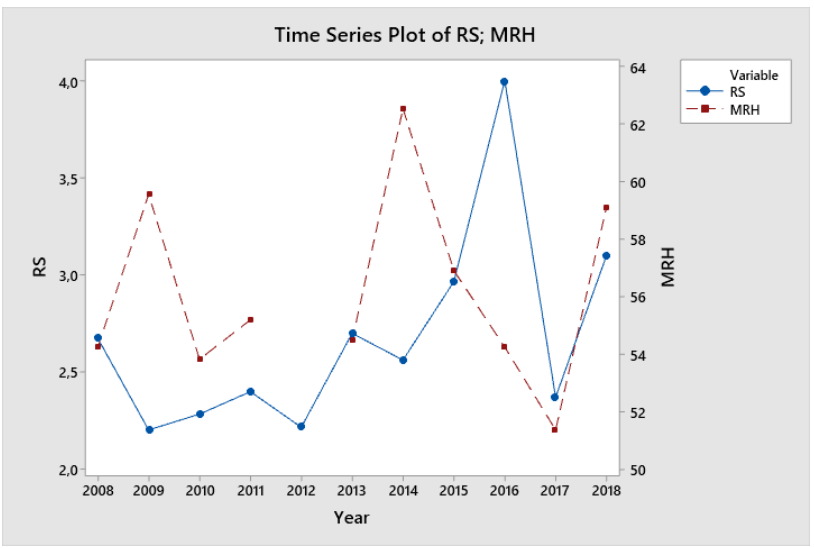

a)

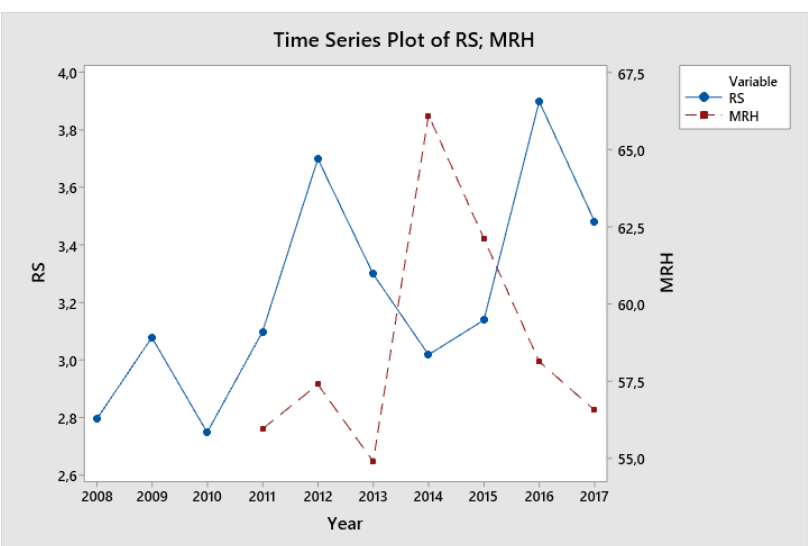

b)

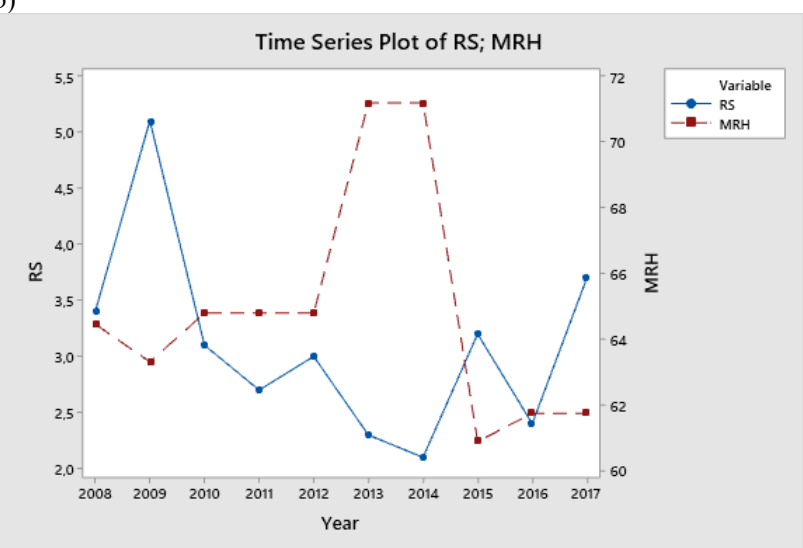

c)

Fig. 23. Time series of Residual Sugars in relation with Mean Relative Humidity of the growing season of three PGIs (A. Serres, B. Drama, C. Paggaio).

\section{C3. Mean Annual Rainfall height}

For the total number of Residual Sugars, next figure (Fig. 24) shows that, as in the previous cases, the time series generally follows the time series of the Mean Annual Rainfall, with the exception of the 2014 and 2016 harvest years and for the Serres area. In the year 2014, there seems to be a smaller quantity of Residual Sugars, while the mean annual precipitation is higher for PGI Serres (A). For PGI Paggaio, there seems to be a reverse trend in Residual Sugars relative to the Mean Annual Rainfall. Also in this case, there is a slight upward trend in the values of Residual Sugars.

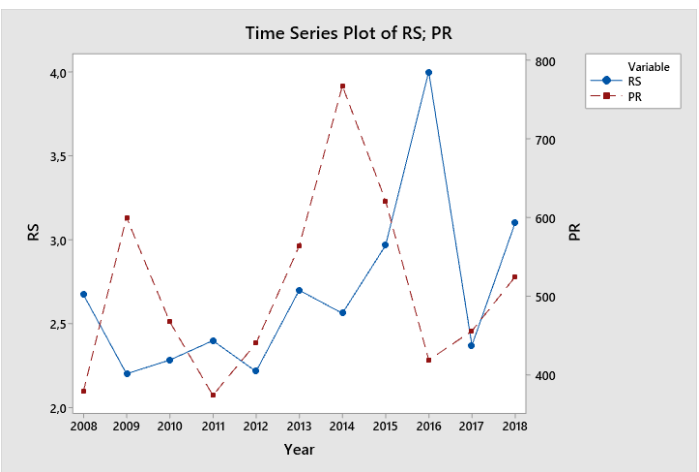

a) 


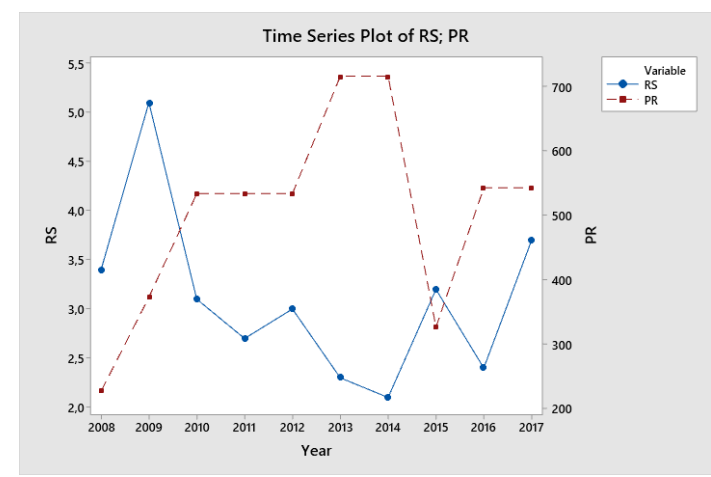

b)

Fig. 24. Time series of Residual Sugars in relation with Mean Annual Rainfall height for the PGI of Serres (A) and PGI Paggaio (B).

Concluding this chapter, it should be summarized that:

- Regarding the classification of the area's wines (based on the samples examined), dry wines are overwhelmingly predominant, as $92 \%$ of the samples tested belonged to this category. In terms of wine color, approximately $11.5 \%$ refer to rosé wines while the rest are evenly distributed between red and white wines. With regard to the red wines, there is a limited aging rate among the samples since only $16 \%$ of the cases concern wine older than two years. For white and rosé wines, it was inevitable from the samples that the previous growing season would perform better than those of previous years.

- Furthermore, the results of the analyses recorded cases at a rate of $8.5 \%$, mainly before 2013 , where a mismatch was detected in the wine with its label and the labels needed to be changed. Concerning non-wine related issues, the same thing occurred in some cases of incorrect wording on the labels, mainly covering issues like font size, and supporting documents for the use of terms such as "Estate", "Tower", and "Vineyards", which all cease to occur after 2013. Finally, the staff of the competent services recorded a very small percentage of cases concerning errors in the composition of PGI wines, but no such case was recorded in the last six years.

- The results show that geographical segregation discerns a tangible indication of differentiation in the three most numerous categories of PGI wines in the area between each other, especially those wines considered statistically significant. It is not possible to formulate a definitive view concerning this segregation, because in terms of statistical analysis, segregation in white wines does not necessarily include data about alcoholic strength. In this respect, the same process will have to be repeated in the future with a greater number of variables, so that geographical segregation will thus be more effective.

- The co-variance analysis for the data obtained from our analyses determined the values of the climatic parameters which were maximized or minimized for each wine parameter. The available data from the statistical analysis succeeded to this effect only for the red wines of the more numerous PGIs. On the contrary, attempts made to apply this for white wines of the same PGI did not yield any results, while it is estimated that the testing of white wines should be repeated when more results from the sample analysis are available. These elements, as well as their further control, will yield valuable conclusions that will have greater value in "designing" new wines, and cultivating new vineyards in the future, even more so because of the ongoing effects of climate change.

- The time analyses series are purely indicative and descriptive in nature. In this context, they provide an overview of the parallel evolution over the years, from one year to another, of the wine parameters in relation to the climatic parameters; in this case, the investigation was related to the three most numerous PGI wine cases. It should be emphasized that in some cases a positive or negative correlation is discerned, while in other cases some of the wine variables such as Total Acidity do not appear to be correlated (quite clearly due to the greater knowledge that winemakers now have and can apply to regulate this parameter).

- It should also be noted that the time series analyses should be repeated in the future when there is a greater amount of data available, and the research can continue at a more detailed level. The value of time series lies in drawing conclusions for the purposes of planning and developing wine production in the area, as well as in assessing the impacts of climate change. It goes without saying that these figures indicate that further research in these directions should be pursued.

\section{Conclusions}

From the results of the analyses conducted on the wine samples, it is quite obvious that it is important to take into account the evolution of the area's viticulture and winemaking history (as mentioned in the introductory chapter of this study), which had been suffering from a sharp decline. However, in the six prefectures of the study area, the dynamics are now showing a recovery, with a rebound in recent decades. This dynamic recovery of the sector in the area is evidenced both by the significant number of wineries established in recent years as well as by the fact that many of the area's wines are already known, both nationally and in many other countries, where they are being favored by consumers. In addition to this performance, it should be noted here that while Greece has experienced a decade-long crisis, all productive and economic opportunities have undergone a powerful crash test. This means that winemaking businesses have already managed to survive in extremely difficult conditions throughout these years, and since they have survived, they can capitalize on the prospects that lie ahead of them, as long as the country's economy returns to normal. It is quite obvious that, in different circumstances, these businesses would have ceased operations because of the prolonged crisis. Thus, in the conclusions, the history of viticulture and winemaking in the area should be included, and these facts should be correlated with the results of this study: viticulture and winemaking were restored, surviving and enduring during the difficult period of the crisis, as already mentioned, with the production of high quality wines. Moreover, it is particularly important to note the fact that in this industry, there is a very high percentage of wines that fall into the Protected Geographical Indication category, exceeding $80 \%$ (in terms of the percentage of samples examined), utilizing important local names in the area, such as Serres, Paggaio, Drama, Avdera etc. An entire framework for the protection of the geographical indications of wines has been produced and implemented by the European Union [26], which demonstrates the importance attached to them. Consumers also place significant value on geographical 
designations of origin, while this effect increases as consumer knowledge grows [25]. As discussed in the literature review, while wine is generally considered to be a product that is highly linked to its production area, the choice of producing PGI wines connects the product even more strongly to the area, as occurs in the present case, and this benefits both the product and the area.

With regard to all categories investigated and highlighted in the course of the control checks and analyses, it should be emphasized that negative observations numerically relate to a very small number of samples. These few cases are associated with older years as such issues are virtually nullified after 2013, a fact that could reasonably be attributed to the experience gained by the executives of the winemaking businesses, resulting in the reduction of problems in the winemaking process. This fact should be linked to the recent recovery of the industry, which is highly substantial, and also to the analyses that are now being made by the competent services since 2008 and 2010. The limitation of negative observations is a direct benefit deriving from the implementation of the foreseen analyses in the existing legislation. Overall, adverse macroscopic observations are kept to a minimum, as are the problems that emerge during taste tests, since $97.1 \%$ of the wines sampled showed no problems in either case.

Based on the analyses carried out, the preservative levels were exceeded at a very low rate of $1.16 \%$, while in $3.09 \%$ of cases, some limits were exceeded concerning the particular wine variety. These figures complement the industry's dynamic return to the area and its success in terms of the high quality achieved by cultivating significant varieties in the area. It is also important to harmonize the produced wines with the applicable national and EU legislation concerning wine specifications, which is demonstrated as being adhered to from the analysis of the samples in this study.

To summarize, the present scientific study presented:

- $\quad$ the results of the analyses with the conclusions that were drawn from them,

- the data and the conclusions drawn from the statistical processing of the geographical breakdown of the results of the analyses, and

- the correlations of the results with the available climatic data of the area, and the conclusions reached in the context of the co-variation and timeseries analyses, in relation to the available climatic data.

In this context, the implications of the study are that winemaking in the six prefectures of the northeastern part of Greece, which has made a significant comeback in recent decades and exploits the area's climatic conditions, as well as the labor, inputs and investments of winegrowers and winemakers, producing high quality products as demonstrated in this work, adhere to the applicable legislation, as demonstrated by the sample analysis in the context of quality control. The wine that is produced here has a strong connection with the area and this provides strong prospects for growth in the sector. Monitoring climate change and taking any possible action to mitigate it is one of the key challenges of our time, as is the cultivation of the sustainable environmental dimension that the industry must also have, while this applies to all production sectors.

Last but not least, it is important to note that, as has been pointed out in the literature, the main challenge is to exploit all the parameters in order to enhance the competitiveness of production under modern market conditions [107]. Useful tools to this end include the geographical separation of data generated from the analyses, the covariance analysis results in relation to the climatic data, and the relevant time series, so that a modern, efficient, sustainable and developmental policy can be effected, which will include planning for the development of viticulture and winemaking in the specific area of the study, and by extension, in every area where viticulture is practiced.

\section{Acknowledgments}

I would like to thank the Ministry of Rural Development and Food of the Hellenic Republic and especially the Decentralized Unit of the Ministry, the Regional Center of Plant Protection, Quality and Phytosanitary Control of Kavala for supplying me with the data of the quality control analyses of the wines of the area of the responsibility of the Center, and for giving me the permission to scientifically process and publish them in the context of my scientific work.

This is an Open Access article distributed under the terms of the Creative Commons Attribution License

\section{References}

[1] N. Garnier and S. M. Valamoti, "Prehistoric wine-making at Dikili Tash (Northern Greece): Integrating residue analysis and archaeobotany," J. Archaeol. Sci., vol. 74, pp. 195-206, Oct. 2016, doi: 10.1016/j.jas.2016.03.003.

[2] N. Robertson, "Athens' Festival of the New Wine," Harv. Stud. Class. Philol., vol. 95, p. 197, 1993, doi: 10.2307/311383.

[3] P. Skiadas and J. Lascaratos, "Dietetics in ancient Greek philosophy: Plato's concepts of healthy diet," Eur. J. Clin. Nutr., vol. 55, no. 7, pp. 532-537, Jul. 2001, doi: 10.1038/sj.ejcn.1601179.

[4] Z. Papakonstantinou, "“A DELIGHT AND A BURDEN' (HES., Sc. 400): WINE AND WINE-DRINKING IN ARCHAIC GREECE,” Anc. Soc., vol. 42, pp. 1-32, 2012.

[5] G. V. Jones and L. B. Webb, "Climate Change, Viticulture, and Wine: Challenges and Opportunities," J. Wine Res., vol. 21, no. 2 3, pp. 103-106, Nov. 2010, doi: 10.1080/09571264.2010.530091.

[6] G. Merkouropoulos and P. Mylona, "Assessment of genetic diversity of Vitis vinifera local cultivars of northern Greece as a means for valorization of vine and wine territorie," Territ. Vin, vol. 8, 2018.

[7] Department of Oenology and Beverage Technology, Eastern Macedonia and Thrace Institute of Technology, Drama, Greece and T. Markopoulos, "Common Agricultural Policy and Local Economy and Development in the Region of Eastern Macedonia Thrace (Greece)," J. Eng. Sci. Technol. Rev., vol. 12, no. 2, pp. 185-223, Apr. 2019, doi: 10.25103/jestr.122.25.

[8] K. Mattas and C. Shrestha, "The food sector and economic growth," Food Policy, vol. 14, no. 1, pp. 67-72, Feb. 1989, doi: 10.1016/0306-9192(89)90027-4.

[9] T. A. Stavrinoudis, P. Tsartas, and G. Chatzidakis, "Study of the major supply factors and business choices affecting the growth rate of wine tourism in Greece," Curr. Issues Tour., vol. 15, no. 7, pp. 627-647, Sep. 2012, doi: 10.1080/13683500.2011.630457.

[10]B. Carmichael, "Understanding the Wine Tourism Experience for Winery Visitors in the Niagara Region, Ontario, Canada," Tour. Geogr., vol. 7, no. 2, pp. 185-204, May 2005, doi: $10.1080 / 14616680500072414$.

[11]S. Charters and S. Pettigrew, "Is wine consumption an aesthetic experience?," J. Wine Res., vol. 16, no. 2, pp. 121-136, Aug. 2005, doi: 10.1080/09571260500327663. 
[12]J. Beckert and Jj. RRssel, "Quality Classifications in Competition: Price Formation in the German Wine Market," SSRN Electron. J., 2012, doi: $10.2139 / \mathrm{ssrn} .2464045$.

[13]L. F. Bisson, A. L. Waterhouse, S. E. Ebeler, M. A. Walker, and J. T. Lapsley, "The present and future of the international wine industry," Nature, vol. 418, no. 6898, pp. 696-699, Aug. 2002, doi: $10.1038 /$ nature 01018 .

[14]P. T. H. Unwin, Wine and the vine: an historical geography of viticulture and the wine trade. London; New York: Routledge, 1991.

[15] "Central Cooperative Union of Wine Products," Central Cooperative Union of Wine Products, 2019. [Online]. Available: https://www.keosoe.gr/keosoe.html.

[16] J. M. Ubalde, X. Sort, A. Zayas, and R. M. Poch, "Effects of Soil and Climatic Conditions on Grape Ripening and Wine Quality of Cabernet Sauvignon," J. Wine Res., vol. 21, no. 1, pp. 1-17, Mar. 2010, doi: 10.1080/09571264.2010.495851.

[17]G. Tagaras, P. Georgiadis, and D. Psoinos, "Development of a Quality-Assurance System for a Wine Producer in Greece," Interfaces, vol. 24, no. 6, pp. 1-13, Dec. 1994, doi: 10.1287/inte.24.6.1.

[18]K. D. Warner, "The quality of sustainability: Agroecological partnerships and the geographic branding of California winegrapes," J. Rural Stud., vol. 23, no. 2, pp. 142-155, Apr. 2007, doi: 10.1016/j.jrurstud.2006.09.009.

[19]A. Alonso Ugaglia, J.-M. Cardebat, and A. Corsi, Eds., The Palgrave Handbook of Wine Industry Economics. Cham: Springer International Publishing, 2019.

[20]A. Corsi, S. Mazzarino, and E. Pomarici, "The Italian Wine Industry," in The Palgrave Handbook of Wine Industry Economics, A. Alonso Ugaglia, J.-M. Cardebat, and A. Corsi, Eds. Cham: Springer International Publishing, 2019, pp. 47-76.

[21] S. Kallithraka, I. S. Arvanitoyannis, P. Kefalas, A. El-Zajouli, E. Soufleros, and E. Psarra, "Instrumental and sensory analysis of Greek wines; implementation of principal component analysis (PCA) for classification according to geographical origin," Food Chem., vol. 73, no. 4, pp. 501-514, Jun. 2001, doi: 10.1016/S03088146(00)00327-7.

[22]T. Christaki and C. Tzia, "Quality and safety assurance in winemaking," Food Control, vol. 13, no. 8, pp. 503-517, Dec. 2002, doi: 10.1016/S0956-7135(02)00030-0.

[23]Department of Economics, Sociology and Management, Centre for Transdisciplinary Development Studies, University of Trás-osMontes and Alto Douro, Vila Real, Portugal, A. Macedo, S. Gouveia, Department of Economics, Sociology and Management, Centre for Transdisciplinary Development Studies, University of Trás-os-Montes and Alto Douro, Vila Real, Portugal, J. Rebelo, and Department of Economics, Sociology and Management, Centre for Transdisciplinary Development Studies, University of Trás-os-Montes and Alto Douro, Vila Real, Portugal, "Does Wine Quality Have a Bearing on Exports?," Agris -Line Pap. Econ. Inform., vol. 11, no. 4, pp. 49-59, Dec. 2019, doi: 10.7160/aol.2019.110405.

[24] T. Kodama, "GIs and the concept of terroir for the development of local wine and sake clusters in Japan," BIO Web Conf., vol. 15, p. 03006, 2019, doi: 10.1051/bioconf/20191503006.

[25] S. Landon and C. E. Smith, "The Use of Quality and Reputation Indicators by Consumers: The Case of Bordeaux Wine," $J$. Consum. Policy, vol. 20, no. 3, pp. 289-323, Sep. 1997, doi: 10.1023/A:1006830218392.

[26] M. Blakeney, The Protection of Geographical Indications. Edward Elgar Publishing, 2019.

[27] S. Charters and S. Pettigrew, "Conceptualizing product quality: the case of wine," Mark. Theory, vol. 6, no. 4, pp. 467-483, Dec. 2006, doi: $10.1177 / 1470593106069932$.

[28] S. Charters and S. Pettigrew, "The dimensions of wine quality," Food Qual. Prefer., vol. 18, no. 7, pp. 997-1007, Oct. 2007, doi: 10.1016/j.foodqual.2007.04.003.

[29]A. Botonaki and E. Tsakiridou *, "Consumer response evaluation of a greek quality wine," Food Econ. - Acta Agric. Scand. Sect. C, vol. 1, no. 2, pp. 91-98, Jun. 2004, doi: $10.1080 / 16507540410024515$.

[30]D. Skuras and A. Vakrou, "Consumers' willingness to pay for origin labelled wine: A Greek case study," Br. Food J., vol. 104, no. 11, pp. 898-912, Dec. 2002, doi: 10.1108/00070700210454622.

[31]A. Krystallis and P. Chrysochou, "An exploration of loyalty determinants in Greek wine varieties," EuroMed J. Bus., vol. 5, no. 2, pp. 124-137, Jul. 2010, doi: 10.1108/14502191011065473.
[32] C. Papalexiou, "Barriers to the Export of Greek Wine," presented at the 113th EAAE, Chania, Crete, Greece, 6/9-2009.

[33]E. Dimara, G. Baourakis, and N. Kalogeras, "CONSUMER PREFERENCES FOR EXTRINSIC VERSUS INTRINSIC QUALITY CUES FOR IMAGE PRODUCTS: THE CASE OF GREEK QUALITY WINE," in Fuzzy Sets in Management, Economics and Marketing, WORLD SCIENTIFIC, 2001, pp. 8398.

[34]D. Aggelogiannopoulos, E. H. Drosinos, and P. Athanasopoulos, "Implementation of a quality management system (QMS) according to the ISO 9000 family in a Greek small-sized winery: A case study," Food Control, vol. 18, no. 9, pp. 1077-1085, Sep. 2007, doi: 10.1016/j.foodcont.2006.07.010.

[35] A. Vlachvei, O. Notta, and T. Efterpi, "Branding Strategies in Greek Wine Firms," Procedia Econ. Finance, vol. 1, pp. 421-430, 2012, doi: 10.1016/S2212-5671(12)00048-2.

[36]M. A. O'Neill and A. Palmer, "Wine Production and Tourism: Adding Service to a Perfect Partnership," Cornell Hotel Restaur. Adm. Q., vol. 45, no. 3, pp. 269-284, Aug. 2004, doi: $10.1177 / 0010880404263075$.

[37] C. Hay, "The political economy of price and status formation in the Bordeaux en primeur market: the role of wine critics as rating agencies," Socio-Econ. Rev., vol. 8, no. 4, pp. 685-707, Oct. 2010, doi: $10.1093 / \mathrm{ser} / \mathrm{mwq} 007$.

[38] I. Arvanitoyannis, "Application of quality control methods for assessing wine authenticity: Use of multivariate analysis (chemometrics)," Trends Food Sci. Technol., vol. 10, no. 10, pp. 321-336, Oct. 1999, doi: 10.1016/S0924-2244(99)00053-9.

[39] S. Aich, A. A. Al-Absi, K. L. Hui, J. T. Lee, and M. Sain, “A classification approach with different feature sets to predict the quality of different types of wine using machine learning techniques," in 2018 20th International Conference on Advanced Communication Technology (ICACT), Chuncheon-si Gangwondo, Korea (South), 2018, pp. 139-143, doi: 10.23919/ICACT.2018.8323674.

[40] M. Anastasiadi, A. Zira, P. Magiatis, S. A. Haroutounian, A. L. Skaltsounis, and E. Mikros, "1 H NMR-Based Metabonomics for the Classification of Greek Wines According to Variety, Region, and Vintage. Comparison with HPLC Data," J. Agric. Food Chem., vol. 57, no. 23, pp. 11067-11074, Dec. 2009, doi: $10.1021 /$ jf902137e.

[41]P. A. Tarantilis, V. E. Troianou, C. S. Pappas, Y. S. Kotseridis, and M. G. Polissiou, "Differentiation of Greek red wines on the basis of grape variety using attenuated total reflectance Fourier transform infrared spectroscopy," Food Chem., vol. 111, no. 1, pp. 192-196, Nov. 2008, doi: 10.1016/j.foodchem.2008.03.020.

[42] R. Gawel and P. W. Godden, "Evaluation of the consistency of wine quality assessments from expert wine tasters," Aust. J. Grape Wine Res., vol. 14, no. 1, pp. 1-8, Apr. 2008, doi: 10.1111/j.17550238.2008.00001.x.

[43] C. J. Brien, P. May, and O. Mayo, "Analysis of Judge Performance in Wine-Quality Evaluations," J. Food Sci., vol. 52, no. 5, pp. 1273-1279, Sep. 1987, doi: 10.1111/j.1365-2621.1987.tb14061.x.

[44] J. Cao, "Quantifying Randomness Versus Consensus in Wine Quality Ratings," J. Wine Econ., vol. 9, no. 2, pp. 202-213, Aug. 2014, doi: 10.1017/jwe.2014.8.

[45]A. Versari, V. F. Laurie, A. Ricci, L. Laghi, and G. P. Parpinello, "Progress in authentication, typification and traceability of grapes and wines by chemometric approaches," Food Res. Int., vol. 60, pp. 2-18, Jun. 2014, doi: 10.1016/j.foodres.2014.02.007.

[46] P. Cortez, A. Cerdeira, F. Almeida, T. Matos, and J. Reis, "Modeling wine preferences by data mining from physicochemical properties," Decis. Support Syst., vol. 47, no. 4, pp. 547-553, Nov. 2009, doi: 10.1016/j.dss.2009.05.016.

[47] J. J. Rudinas, "White Wine Quality Dataset," Wine Quality Dataset, 2019. [Online]. Available: https://rpubs.com/joelrudinas03/WQD.

[48] G. Hu, T. Xi, F. Mohammed, and H. Miao, "Classification of wine quality with imbalanced data," in 2016 IEEE International Conference on Industrial Technology (ICIT), Taipei, Taiwan, 2016, pp. 1712-1217, doi: 10.1109/ICIT.2016.7475021.

[49] S. Petropoulos, C. S. Karavas, A. T. Balafoutis, I. Paraskevopoulos, S. Kallithraka, and Y. Kotseridis, "Fuzzy logic tool for wine quality classification," Comput. Electron. Agric., vol. 142, pp. 552-562, Nov. 2017, doi: 10.1016/j.compag.2017.11.015.

[50]H. F. Linskens and J. F. Jackson, "Wine Analysis," in Wine Analysis, vol. 6, H.-F. Linskens and J. F. Jackson, Eds. Berlin, Heidelberg: Springer Berlin Heidelberg, 1988, pp. 1-8. 
[51]K. Pasvanka, A. Tzachristas, and C. Proestos, "Quality Tools in Wine Traceability and Authenticity," in Quality Control in the Beverage Industry, Elsevier, 2019, pp. 289-334.

[52]Y. Er, "The Classification of White Wine and Red Wine According to Their Physicochemical Qualities," Int. J. Intell. Syst. Appl. Eng., vol. 4, no. Special Issue-1, pp. 23-26, Dec. 2016, doi: 10.18201/ijisae.265954.

[53]A. E. Ozalp and I. Askerzade, "A data science study for determining food quality: an application to wine," Commun. Fac. Sci. Univ. Ank. Ser. A1Mathematics Stat., vol. 68, no. 1, pp. 762-770, Apr. 2018, doi: 10.31801/cfsuasmas.469131.

[54]N. Perrot, I. Ioannou, I. Allais, C. Curt, J. Hossenlopp, and G. Trystram, "Fuzzy concepts applied to food product quality control: A review," Fuzzy Sets Syst., vol. 157, no. 9, pp. 1145-1154, May 2006, doi: 10.1016/j.fss.2005.12.013.

[55]X. Uniyal and P. Barthwal, "Wine Quality Evaluation Using Machine Learning Algorithms," Asia-Pac. J. Converg. Res. Interchange, vol. 3, no. 4, pp. 1-9, Dec. 2017, doi: 10.21742/apjcri.2017.12.07.

[56]. S. D., . S. J., . G. M., and . S. N. N., "ANALYZING WINE TYPES AND QUALITY USING MACHINE LEARNING TECHNIQUES," Int. J. Eng. Appl. Sci. Technol., vol. 4, no. 3, pp. 519-529, Jul. 2019, doi: 10.33564/IJEAST.2019.v04i03.080.

[57]R. RINSON and N. SIDDHARTH, "DATA ANALYTICS OF WINE QUALITY IN RSTUDIO,” J. Gujarat Res. Soc., vol. 21, no. 14, pp. 362-268, 2019.

[58]C. Yongxin, Z. Tianhao, and M. Xinyin, "Wine Quality Analysis (2019-US-EPO-255)," in Discovery Summit Tucson 2019, 2019.

[59]D. Lazaridou, "An analysis of Chinese wine market as opportunity for the extraversion of Greek wine enterprises," MSc Thesis, International Hellenic University, Thessaloniki, 2015.

[60] J. Palmer and B. Chen, "Wineinformatics: Regression on the Grade and Price of Wines through Their Sensory Attributes," Fermentation, vol. 4, no. 4, p. 84, Sep. 2018, doi: 10.3390 /fermentation 4040084 .

[61] S. Gutner, G. Silche, and von W. Harald, "Wine Quality and Price: A hedonic approach," in Global Markets For Processed Foods, 1998.

[62]D. I. Jackson and P. B. Lombard, "Environmental and Management Practices Affecting Grape Composition and Wine Quality - A Review," Am. J. Enol. Vitic., vol. 44, no. 4, p. 409, Jan. 1993.

[63]E. Oczkowski and H. Doucouliagos, "Wine Prices and Quality Ratings: A Meta-regression Analysis," Am. J. Agric. Econ., vol. 97, no. 1, pp. 103-121, Jan. 2015, doi: 10.1093/ajae/aau057.

[64]M. Gil et al., "Effect of Two Different Treatments for Reducing Grape Yield in Vitis vinifera cv Syrah on Wine Composition and Quality: Berry Thinning versus Cluster Thinning," J. Agric. Food Chem., vol. 61, no. 20, pp. 4968-4978, May 2013, doi: 10.1021/jf400722z.

[65]D. M. Chapman, M. A. Matthews, and J.-X. Guinard, "Sensory Attributes of Cabernet Sauvignon Wines Made from Vines with Different Crop Yields," Am. J. Enol. Vitic., vol. 55, no. 4, p. 325, Jan. 2004.

[66]R. G. V. Bramley, J. Ouzman, and P. K. Boss, "Variation in vine vigour, grape yield and vineyard soils and topography as indicators of variation in the chemical composition of grapes, wine and wine sensory attributes: Vineyard variation in wines, grapes and soils," Aust. J. Grape Wine Res., vol. 17, no. 2, pp. 217-229, Jun. 2011, doi: 10.1111/j.1755-0238.2011.00136.x.

[67]G. Cheng, Y. Liu, T.-X. Yue, and Z.-W. Zhang, "Comparison between aroma compounds in wines from four Vitis vinifera grape varieties grown in different shoot positions," Food Sci. Technol. Camp., vol. 35, no. 2, pp. 237-246, Jun. 2015, doi: 10.1590/1678457 X.6438.

[68]C. González-Barreiro, R. Rial-Otero, B. Cancho-Grande, and J. Simal-Gándara, "Wine Aroma Compounds in Grapes: A Critical Review," Crit. Rev. Food Sci. Nutr., vol. 55, no. 2, pp. 202-218, Jan. 2015, doi: 10.1080/10408398.2011.650336.

[69] S. T. Lund, "The Molecular Basis for Wine Grape Quality-A Volatile Subject," Science, vol. 311, no. 5762, pp. 804-805, Feb. 2006, doi: 10.1126/science. 1118962 .

[70]M. Trought, "Fruitset - possible implications on wine quality," Transform. Flowers Fruit Proc. ASVO Semin., pp. 27-31, 2005.

[71]G. V. Jones, R. Reid, and A. Vilks, "Climate, Grapes, and Wine: Structure and Suitability in a Variable and Changing Climate," in The Geography of Wine, P. H. Dougherty, Ed. Dordrecht: Springer Netherlands, 2012, pp. 109-133.

[72]H. Fraga, A. C. Malheiro, J. Moutinho-Pereira, and J. A. Santos, "Climate factors driving wine production in the Portuguese Minho region," Agric. For. Meteorol., vol. 185, pp. 26-36, Feb. 2014, doi: 10.1016/j.agrformet.2013.11.003.

[73] C. J. Soar, V. O. Sadras, and P. R. Petrie, "Climate drivers of red wine quality in four contrasting Australian wine regions," Aust. J. Grape Wine Res., vol. 14, no. 2, pp. 78-90, Jul. 2008, doi: 10.1111/j.1755-0238.2008.00011.x.

[74] A. Hall and G. V. Jones, "Spatial analysis of climate in winegrapegrowing regions in Australia: Climate in winegrape growing regions in Australia," Aust. J. Grape Wine Res., vol. 16, no. 3, pp. 389-404, Sep. 2010, doi: 10.1111/j.1755-0238.2010.00100.x.

[75] O. Ashenfelter, D. Ashmore, and R. Lalonde, "Bordeaux Wine Vintage Quality and the Weather," CHANCE, vol. 8, no. 4, pp. 714, Sep. 1995, doi: 10.1080/09332480.1995.10542468.

[76] G. V. Jones and R. E. Davis, "Climate Influences on Grapevine Phenology, Grape Composition, and Wine Production and Quality for Bordeaux, France," Am. J. Enol. Vitic., vol. 51, no. 3, p. 249, Jan. 2000.

[77] J. A. Jackman et al., "Nanotechnology Education for the Global World: Training the Leaders of Tomorrow," ACS Nano, vol. 10, no. 6, pp. 5595-5599, Jun. 2016, doi: 10.1021/acsnano.6b03872.

[78] D. Grifoni, M. Mancini, G. Maracchi, S. Orlandini, and G. Zipoli, "Analysis of Italian Wine Quality Using Freely Available Meteorological Information," Am. J. Enol. Vitic., vol. 57, no. 3, p. 339, Sep. 2006

[79]A. D. Marta, D. Grifoni, M. Mancini, P. Storchi, G. Zipoli, and S. Orlandini, "Analysis of the relationships between climate variability and grapevine phenology in the Nobile di Montepulciano wine production area," J. Agric. Sci., vol. 148, no. 6, pp. 657-666, Dec. 2010, doi: 10.1017/S0021859610000432.

[80] J. D. Dalu et al., "Mediterranean climate patterns and wine quality in North and Central Italy," Int. J. Biometeorol., vol. 57, no. 5, pp. 729-742, Sep. 2013, doi: 10.1007/s00484-012-0600-4.

[81] S. Koundouras, V. Marinos, A. Gkoulioti, Y. Kotseridis, and C. van Leeuwen, "Influence of Vineyard Location and Vine Water Status on Fruit Maturation of Nonirrigated Cv. Agiorgitiko ( Vitis vinifera L.). Effects on Wine Phenolic and Aroma Components," J. Agric. Food Chem., vol. 54, no. 14, pp. 5077-5086, Jul. 2006, doi: $10.1021 / \mathrm{jf0605446.}$

[82] S. Shanmuganathan, P. Sallis, and A. Narayanan, "Data Mining Techniques for Modelling Seasonal Climate Effects on Grapevine Yield and Wine Quality," in 2010 2nd International Conference on Computational Intelligence, Communication Systems and Networks, Liverpool, United Kingdom, 2010, pp. 84-89, doi: 10.1109/CICSyN.2010.16.

[83] T. Holland and B. Smit, "Climate Change and the Wine Industry: Current Research Themes and New Directions," J. Wine Res., vol. 21, no. 2-3, pp. 125-136, Nov. 2010, doi: 10.1080/09571264.2010.530095.

[84] L. Makra, B. Vitányi, A. Gál, J. Mika, I. Matyasovszky, and T. Hirsch, "Wine Quantity and Quality Variations in Relation to Climatic Factors in the Tokaj (Hungary) Winegrowing Region," Am. J. Enol. Vitic., vol. 60, no. 3, p. 312, Sep. 2009.

[85]C. D. Ramirez, "Wine Quality, Wine Prices, and the Weather: Is Napa 'Different'?,' J. Wine Econ., vol. 3, no. 2, pp. 114-131, 2008, doi: 10.1017/S1931436100001164.

[86] M. R. Mozell and L. Thach, "The impact of climate change on the global wine industry: Challenges \& solutions," Wine Econ. Policy, vol. 3, no. 2, pp. 81-89, Dec. 2014, doi: 10.1016/j.wep.2014.08.001.

[87] B. I. Cook and E. M. Wolkovich, "Climate change decouples drought from early wine grape harvests in France," Nat. Clim. Change, vol. 6, no. 7, pp. 715-719, Jul. 2016, doi: 10.1038/nclimate2960.

[88] R. Mira de Orduña, "Climate change associated effects on grape and wine quality and production," Food Res. Int., vol. 43, no. 7, pp. 1844-1855, Aug. 2010, doi: 10.1016/j.foodres.2010.05.001.

[89] J.-M. Chevet, S. Lecocq, and M. Visser, "Climate, Grapevine Phenology, Wine Production, and Prices: Pauillac (1800-2009)," Am. Econ. Rev., vol. 101, no. 3, pp. 142-146, May 2011, doi: 10.1257/aer.101.3.142.

[90] G. V. Jones, M. A. White, O. R. Cooper, and K. Storchmann, "Climate Change and Global Wine Quality," Clim. Change, vol. 73, no. 3, pp. 319-343, Dec. 2005, doi: 10.1007/s10584-005-47042.

[91] S. I. Seneviratne, D. Lüthi, M. Litschi, and C. Schär, "Landatmosphere coupling and climate change in Europe," Nature, vol. 443, no. 7108, pp. 205-209, Sep. 2006, doi: 10.1038/nature05095.

[92] G. Jones and G. Goodrich, "Influence of climate variability on wine regions in the western USA and on wine quality in the Napa 
Valley," Clim. Res., vol. 35, pp. 241-254, Feb. 2008, doi: $10.3354 / \mathrm{cr} 00708$.

[93]C. van Leeuwen and P. Darriet, "The Impact of Climate Change on Viticulture and Wine Quality," J. Wine Econ., vol. 11, no. 1, pp. 150-167, May 2016, doi: 10.1017/jwe.2015.21.

[94]E. Duchêne, F. Huard, V. Dumas, C. Schneider, and D. Merdinoglu, "The challenge of adapting grapevine varieties to climate change," Clim. Res., vol. 41, no. 3, pp. 193-204, May 2010, doi: $10.3354 / \mathrm{cr} 00850$.

[95]K. Storchmann, "English weather and Rhine wine quality: An ordered probit model," J. Wine Res., vol. 16, no. 2, pp. 105-120, Aug. 2005, doi: 10.1080/09571260500327648.

[96]L. Webb, P. Whetton, and E. Barlow, "Climate change and winegrape quality in Australia," Clim. Res., vol. 36, pp. 99-111, Apr. 2008, doi: 10.3354/cr00740.

[97]M. Ramos, G. Jones, and J. Martínez-Casasnovas, "Structure and trends in climate parameters affecting winegrape production in northeast Spain," Clim. Res., vol. 38, pp. 1-15, Nov. 2008, doi: $10.3354 / \mathrm{cr} 00759$.

[98] A. Pons, L. Allamy, A. Schüttler, D. Rauhut, C. Thibon, and P. Darriet, "What is the expected impact of climate change on wine aroma compounds and their precursors in grape?," OENO One, vol. 51, no. 2, pp. 141-146, May 2017, doi: 10.20870/oenoone.2017.51.2.1868.

[99]I. L. Francis and J. L. Newton, "Determining wine aroma from compositional data," Aust. J. Grape Wine Res., vol. 11, no. 2, pp. 114-126, Jul. 2005, doi: 10.1111/j.1755-0238.2005.tb00283.x.
[100] G. C. Koufos, T. Mavromatis, S. Koundouras, and G. V. Jones, "Response of viticulture-related climatic indices and zoning to historical and future climate conditions in Greece: RESPONSE OF VITICULTURE-RELATED CLIMATIC INDICES AND ZONING IN GREECE," Int. J. Climatol., vol. 38, no. 4, pp. $2097-$ 2111, Mar. 2018, doi: 10.1002/joc.5320.

[101] Directorate for Processing, Standardization and Quality Control of the Ministry of Rural Development \& Food, Designation of test sampling of wine products. 2004.

[102] A. P. Field, Discovering statistics using SPSS: and sex, drugs and rock " $n$ " roll, 3rd ed. Los Angeles: SAGE Publications, 2009.

[103] D. C. Montgomery, Design and analysis of experiments, Eighth edition. Hoboken, NJ: John Wiley \& Sons, Inc, 2013.

[104] D. G. Kleinbaum and D. G. Kleinbaum, Eds., Applied regression analysis and other multivariable methods, 3rd ed. Pacific Grove: Duxbury Press, 1998.

[105] Minitab, LLC. State College, 2018.

[106] "Wines - POP," Ministry of Rural Development and Food of the Hellenic Republic. [Online]. Available: http://w2.minagric.gr/index.php/el/for-farmer-2/cropproduction/ampeli/oin/627-oinoipoppge.

[107] A. Alonso Ugaglia, J.-M. Cardebat, and L. Jiao, "The French Wine Industry," in The Palgrave Handbook of Wine Industry Economics, A. Alonso Ugaglia, J.-M. Cardebat, and A. Corsi, Eds. Cham: Springer International Publishing, 2019, pp. 17-46. 
Appendix A.

TOTAL ALCOOLIC STRENGTH

Table A1. ANCOVA results for Total Alcoholic Strength

\begin{tabular}{|c|c|c|c|c|c|c|c|}
\hline \multirow[b]{2}{*}{ Source } & \multicolumn{6}{|c|}{ Analysis of Variance } & \multirow[b]{2}{*}{ P-Value } \\
\hline & DF & Seq SS & Contribution & Adj SS & Adj MS & F-Value & \\
\hline MT & 1 & 0,3608 & $0,66 \%$ & 0,0351 & 0,03507 & 0,08 & 0,781 \\
\hline $\mathrm{MRH}$ & 1 & 0,0026 & $0,00 \%$ & 0,1067 & 0,10666 & 0,24 & 0,628 \\
\hline Area & 2 & 5,6061 & $10,24 \%$ & 5,6061 & 2,80303 & 6,21 & 0,003 \\
\hline Error & 108 & 48,7658 & $89,09 \%$ & 48,7658 & 0,45153 & & \\
\hline Lack-of-Fit & 25 & 12,1658 & $22,23 \%$ & 12,1658 & 0,48663 & 1,10 & 0,358 \\
\hline Pure Error & 83 & 36,5999 & $66,87 \%$ & 36,5999 & 0,44096 & & \\
\hline Total & 112 & 54,7352 & $100,00 \%$ & & & & \\
\hline
\end{tabular}

Table A2. Maximum and Minimum estimated value of Total Alcoholic Strength and its Confident and Prediction intervals.

$\begin{array}{lrrrc}\text { Variable } & \text { Setting } & & & \\ \text { MT } & 25,17 & & & \\ \text { MRH } & 51,3884 & & & \\ \text { Area } & \text { Drama } & & & \text { 95\% PI } \\ \text { Response } & \text { Fit } & \text { SE Fit } & \mathbf{9 5 \%} \text { CI } & (13,042 ; 15,824)\end{array}$

Variable Multiple Response Prediction

$\begin{array}{lrrcc}\text { Variable } & \text { Setting } & & & \\ \text { MT } & 19,1467 & & & \\ \text { MRH } & 71,185 & & & \mathbf{9 5 \%} \text { PI } \\ \text { Area } & \text { Paggaio } & & & \\ \text { Response } & \text { Fit } & \text { SE Fit } & \mathbf{9 5 \%} \text { CI } & (12,089 ; 14,986)\end{array}$

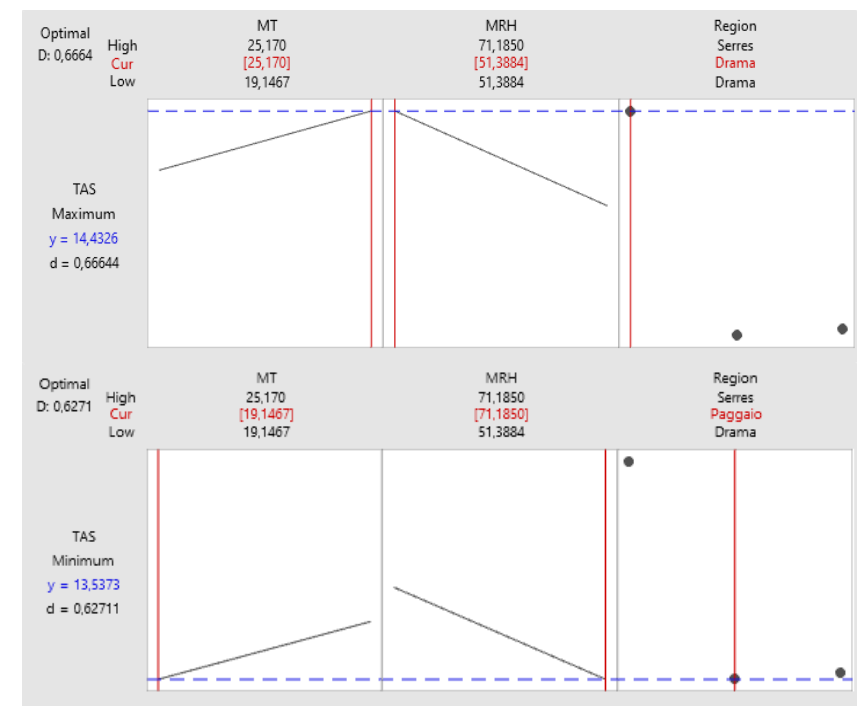

Fig. A1. A graphical representation of maximization and minimization of Total Alcoholic Strength. 
OBTAINED ALCOOLIC STRENGTH

Table A3. ANCOVA results for Obtained Alcoholic Strength

\begin{tabular}{lrrrrrrr} 
Source & DF & Seq SS & Contribution & Adj SS & Adj MS & F-Value & P-Value \\
\hline MT & 1 & 0,3311 & $0,62 \%$ & 0,0357 & 0,03566 & 0,08 & 0,778 \\
MRH & 1 & 0,0018 & $0,00 \%$ & 0,0549 & 0,05492 & 0,12 & 0,727 \\
Area & 2 & 4,4033 & $8,31 \%$ & 4,4033 & 2,20166 & 4,92 & 0,009 \\
Error & 108 & 48,2803 & $91,07 \%$ & 48,2803 & 0,44704 & & \\
Lack-of-Fit & 25 & 11,9091 & $22,46 \%$ & 11,9091 & 0,47636 & 1,09 & 0,376 \\
Pure Error & 83 & 36,3712 & $68,60 \%$ & 36,3712 & 0,43821 & & \\
Total & 112 & 53,0166 & $100,00 \%$ & & & &
\end{tabular}

Table A4. Maximum and Minimum estimated value of Obtained Alcoholic Strength and its Confident and Prediction intervals.

\begin{tabular}{lrrcc} 
Variable & Setting & & \multicolumn{2}{c}{ Multiple Response Prediction } \\
\hline MT & 25,17 & & & \\
MRH & 51,3884 & & & \\
Area & Drama & & $95 \%$ CI & 95\% PI \\
Response & Fit & SE Fit & $(13,792 ; 14,591)$ & $(12,807 ; 15,575)$
\end{tabular}

$\begin{array}{lrrrr}\text { Variable } & \text { Setting } & & & \text { Multiple Response Predic } \\ \text { MT } & 19,1467 & & & \\ \text { MRH } & 71,185 & & & \\ \text { Area } & \text { Paggaio } & & & \mathbf{9 5 \%} \text { PI } \\ \text { Response } & \text { Fit } & \text { SE Fit } & \mathbf{9 5 \%} \text { CI } & (11,932 ; 14,815)\end{array}$

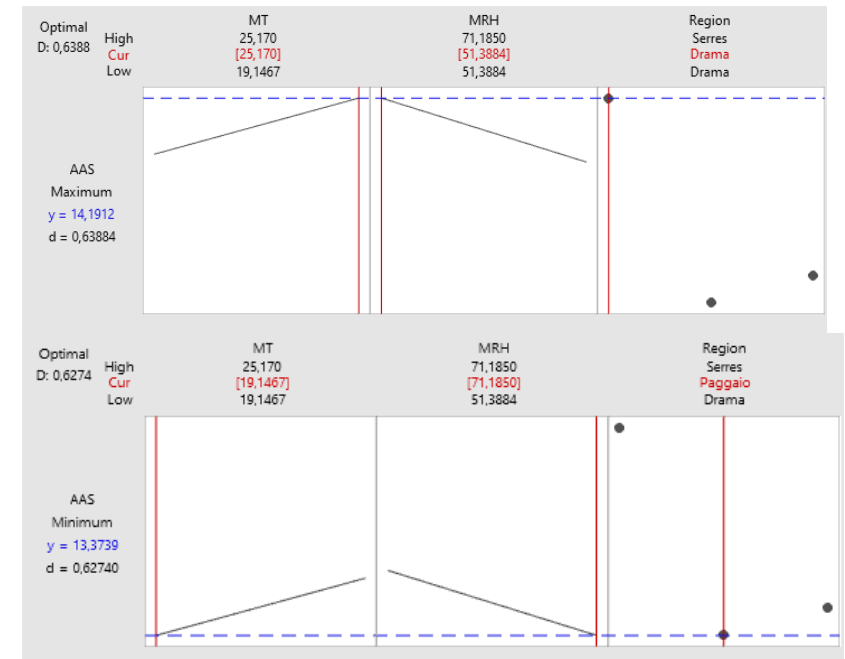

Fig. A2. A graphical representation of maximization and minimization of Obtained Alcoholic Strength. 
TOTAL ACIDITY

Table A5. ANCOVA results for Total Acidity

\begin{tabular}{lrrrrrrr} 
& \multicolumn{9}{c}{ Analysis of Variance } \\
Source & DF & Seq SS & Contribution & Adj SS & Adj MS & F-Value & P-Value \\
\hline MT & 1 & 0,4295 & $1,00 \%$ & 0,5110 & 0,510969 & 1,35 & 0,248 \\
MRH & 1 & 0,2532 & $0,59 \%$ & 0,0040 & 0,003956 & 0,01 & 0,919 \\
Area & 2 & 1,4074 & $3,27 \%$ & 1,4074 & 0,903717 & 2,86 & 0,041 \\
Error & 108 & 40,9271 & $95,14 \%$ & 40,9271 & 0,378955 & & \\
Lack-of-Fit & 25 & 9,5580 & $22,22 \%$ & 9,5580 & 0,382318 & 1,01 & 0,463 \\
Pure Error & 83 & 31,3691 & $72,92 \%$ & 31,3691 & 0,377942 & & \\
Total & 112 & 43,0172 & $100,00 \%$ & & & &
\end{tabular}

Table A6. Maximum and Minimum estimated value of Total Acidity and its Confident and Prediction intervals.

\begin{tabular}{lcccc} 
Variable & Setting & & & Multiple Response P \\
\hline MT & 19,1467 & & & \\
MRH & 51,3884 & & & \\
Area & Serres & & & \\
Response & Fit & SE Fit & $\mathbf{9 5 \%}$ CI & $\mathbf{9 5 \%}$ PI \\
\hline TA & 5,600 & 0,413 & $(4,781 ; 6,419)$ & $(4,131 ; 7,070)$
\end{tabular}

\section{Multiple Response Prediction}

\begin{tabular}{lrrcc}
\hline MT & 25,17 & & & \\
MRH & 71,185 & & & \\
Area & Drama & & & $\mathbf{9 5 \%}$ PI \\
Response & Fit & SE Fit & $\mathbf{9 5 \%}$ CI & $\mathbf{9 5}$. \\
\hline TA & 4,754 & 0,378 & $(4,005 ; 5,503)$ & $(3,322 ; 6,186)$
\end{tabular}

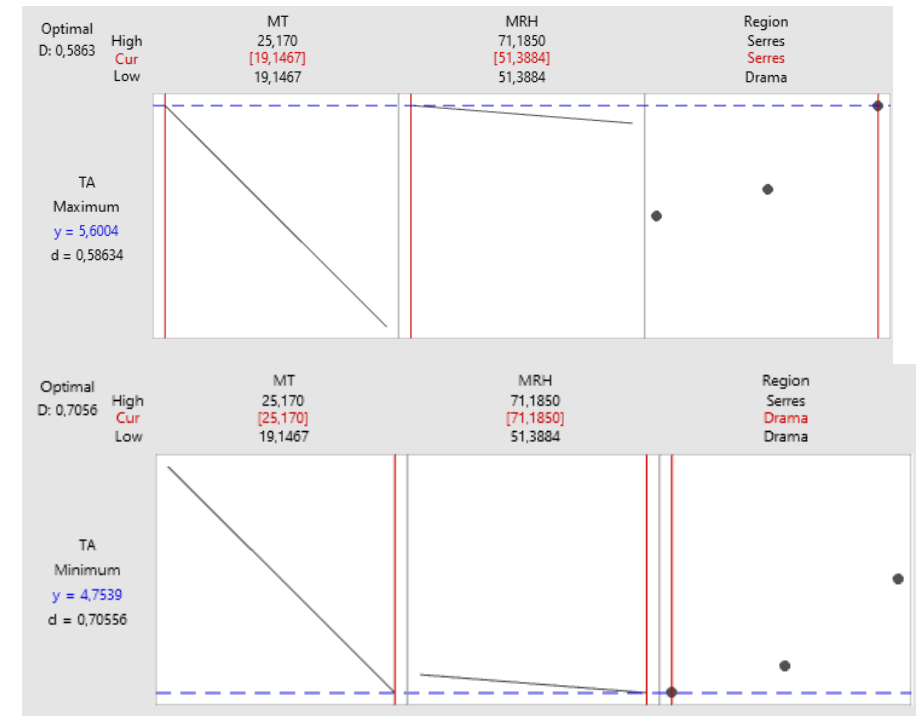

Fig. A3. A graphical representation of maximization and minimization of Total Acidity. 
VOLATILE ACIDITY

Table A7. ANCOVA results for Volatile Acidity.

\begin{tabular}{lrrrrrrr} 
& \multicolumn{9}{c}{ Analysis of Variance } \\
Source & DF & Seq SS & Contribution & Adj SS & Adj MS & F-Value & P-Value \\
\hline MT & 1 & 0,378 & $0,04 \%$ & 0,222 & 0,2223 & 0,03 & 0,859 \\
MRH & 1 & 11,491 & $1,32 \%$ & 1,818 & 1,8175 & 0,26 & 0,612 \\
Area & 2 & 100,607 & $11,55 \%$ & 100,607 & 50,3037 & 7,16 & 0,001 \\
Error & 108 & 758,664 & $87,09 \%$ & 758,664 & 7,0247 & & \\
Lack-of-Fit & 25 & 183,654 & $21,08 \%$ & 183,654 & 7,3462 & 1,06 & 0,405 \\
Pure Error & 83 & 575,009 & $66,01 \%$ & 575,009 & 6,9278 & &
\end{tabular}

Table A8. Maximum and Minimum estimated value of Volatile Acidity and its Confident and Prediction intervals.

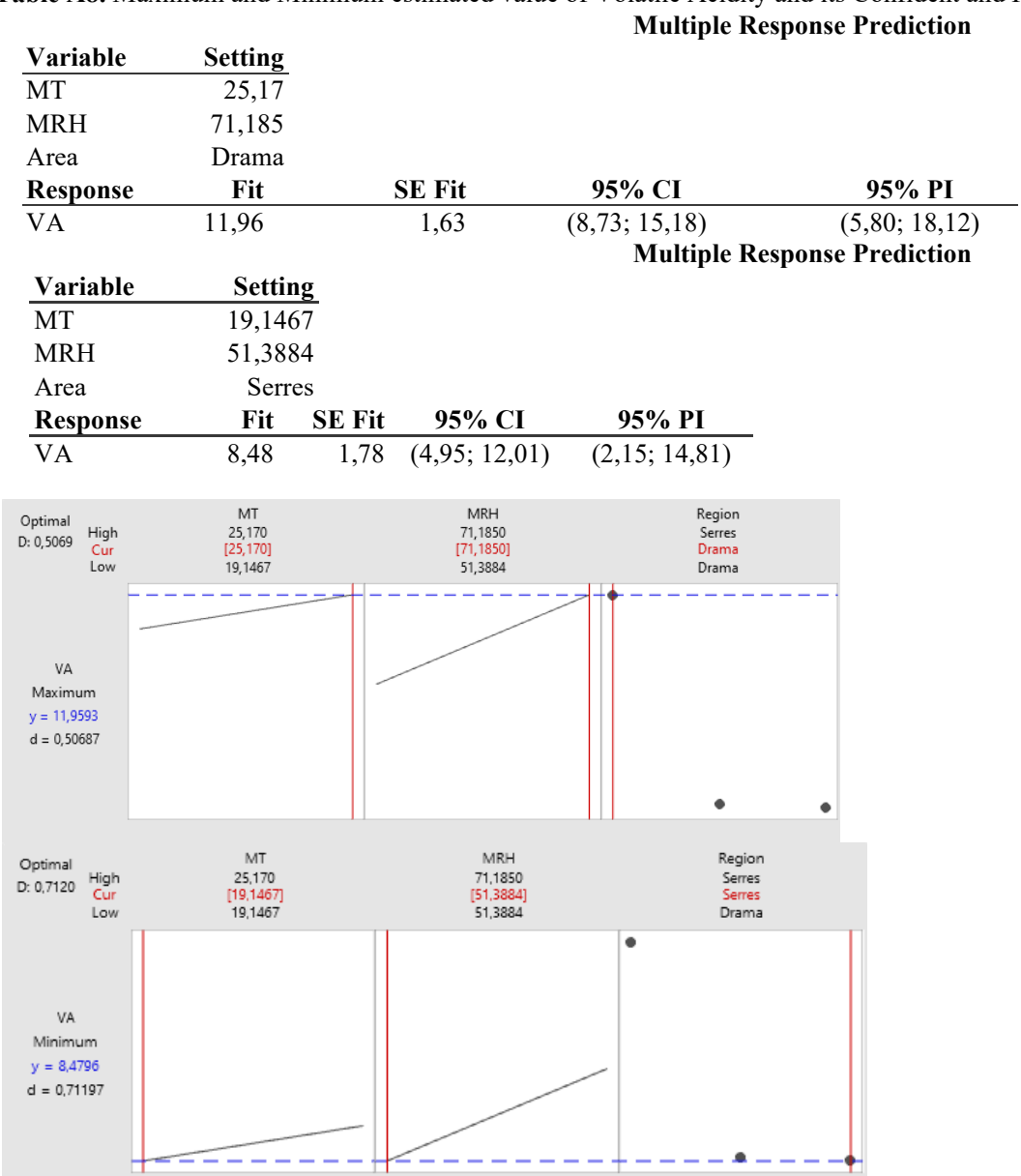

Fig. A4. A graphical representation of maximization and minimization of Volatile Acidity. 
RESIDUAL SUGARS

Table A9. ANCOVA results for Residual Sugars

\begin{tabular}{lrrrrrrr} 
Source & DF & Seq SS & Contribution & Adj SS & Adj MS & F-Value & P-Value \\
\hline MT & 1 & 0,161 & $0,16 \%$ & 0,1196 & 0,1196 & 0,15 & 0,701 \\
MRH & 1 & 0,217 & $0,21 \%$ & 0,8236 & 0,8236 & 1,02 & 0,315 \\
Area & 2 & 13,189 & $13,07 \%$ & 13,1886 & 6,5943 & 8,15 & 0,001 \\
Error & 108 & 87,376 & $86,56 \%$ & 87,3757 & 0,8090 & & \\
Lack-of-Fit & 25 & 38,761 & $38,40 \%$ & 38,7614 & 1,5505 & 2,65 & 0,001 \\
Pure Error & 83 & 48,614 & $48,16 \%$ & 48,6143 & 0,5857 & & \\
Total & 112 & 100,942 & $100,00 \%$ & & & &
\end{tabular}

Table A10. Maximum and Minimum estimated value of Residual Sugars and its Confident and Prediction intervals.

Multiple Response Prediction

\begin{tabular}{lrrcr} 
Variable & Setting & & & \\
\hline MT & 25,17 & & & \\
MRH & 51,3884 & & & $\mathbf{9 5 \%}$ PI \\
Area & Paggaio & SE Fit & $\mathbf{9 5 \%}$ CI & $(1,657 ; 5,668)$ \\
Response & Fit & 0,464 & $(2,743 ; 4,582)$ &
\end{tabular}

\begin{tabular}{lr} 
Variable & Setting \\
\hline MT & 19,1467
\end{tabular}

$\begin{array}{lr}\text { MRH } & 71,185\end{array}$

Area Serres

\begin{tabular}{lrrcc} 
Response & Fit & SE Fit & $\mathbf{9 5 \%}$ CI & 95\% PI \\
\hline RS & 1,983 & 0,440 & $(1,111 ; 2,855)$ & $(-0,002 ; 3,968)$
\end{tabular}

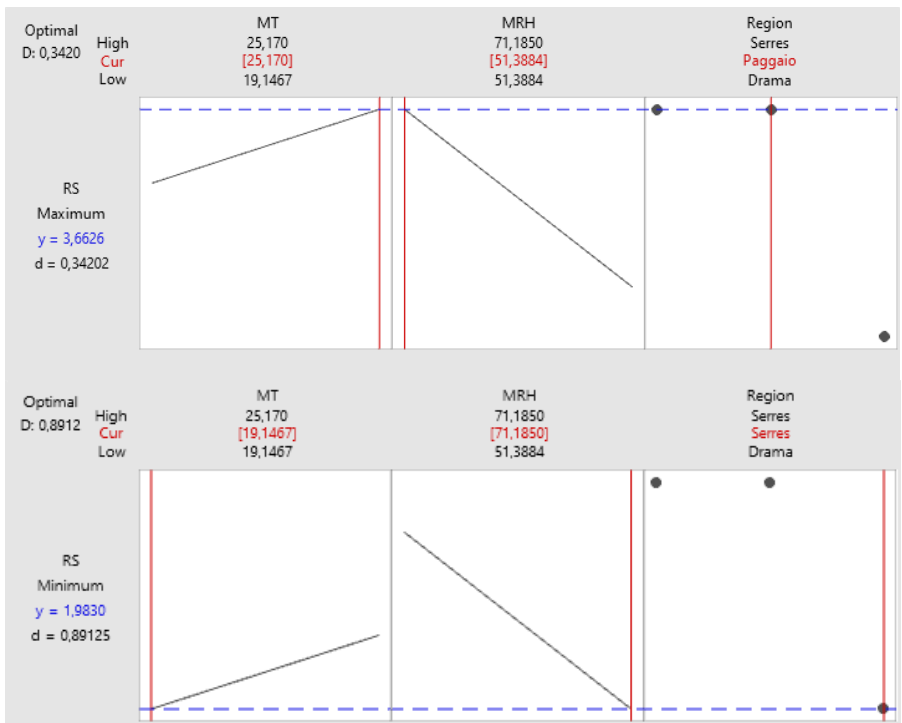

Fig. A5. A graphical representation of maximization and minimization of Residual Sugars. 
Appendix B.

Table B1. Samples from Regional District (Prefecture) of Drama

\begin{tabular}{|c|c|c|c|c|c|c|c|c|c|c|c|c|c|c|c|c|c|c|}
\hline $\begin{array}{l}\text { Year of } \\
\text { analysis }\end{array}$ & WINERY & WINE & $\begin{array}{c}\text { Wine } \\
\text { Category }\end{array}$ & $\begin{array}{c}\text { Wine } \\
\text { container } \\
\text { (except } \\
\text { bottles) }\end{array}$ & $\begin{array}{l}\text { Year of } \\
\text { Harvest }\end{array}$ & Colour & $\begin{array}{c}\text { Type of } \\
\text { Wine }\end{array}$ & \begin{tabular}{|c|} 
Total \\
Alcoholic \\
Strength \\
$(\%$ Vol. 20o \\
C)
\end{tabular} & $\begin{array}{c}\text { Obtained } \\
\text { Alcoholic } \\
\text { Strength } \\
(\% \text { Vol. 20o } \\
\text { C) }\end{array}$ & $\begin{array}{c}\text { Total } \\
\text { Acidity } \\
\text { (g/l } \\
\text { tartaric } \\
\text { acid) }\end{array}$ & $\begin{array}{l}\text { Volatile } \\
\text { Acidity } \\
\text { (meq/l) }\end{array}$ & $\begin{array}{c}\text { Total } \\
\text { Sulphur } \\
(\mathrm{mg} / \mathrm{l})\end{array}$ & $\begin{array}{c}\text { Free } \\
\text { Sulphur } \\
(\mathrm{mg} / \mathrm{l})\end{array}$ & $\begin{array}{c}\text { Sorbic } \\
\text { Acid } \\
(\mathrm{mg} / \mathrm{l})\end{array}$ & pH & $\begin{array}{c}\text { Density of } \\
\text { Wine } \\
(\mathrm{g} / \mathrm{ml})\end{array}$ & \begin{tabular}{|c|} 
Total Wine \\
Solid \\
Residues or \\
Total Dry \\
Extract of \\
Wine (g/l)
\end{tabular} & $\begin{array}{c}\text { Residual } \\
\text { Sugars (g/l) }\end{array}$ \\
\hline 2008 & WINERY 25 & W25.1 & Drama - LW & & 2007 & WHITE & $\begin{array}{c}\text { Dry } \\
\text { wine }\end{array}$ & 12,39 & 12,27 & 6,1 & 5,6 & 119 & & & 3,05 & & & 2 \\
\hline 2008 & WINERY 25 & W25.2 & Drama - LW & & 2004 & RED & $\begin{array}{l}\text { Dry } \\
\text { wine }\end{array}$ & 13,4 & 13,25 & 4,9 & 10,6 & 57 & & & 3,63 & & & 2,5 \\
\hline 2010 & WINERY 37 & W37.1 & $\begin{array}{c}\text { Macedonia - } \\
\text { LW }\end{array}$ & & 2008 & RED & $\begin{array}{l}\text { Dry } \\
\text { wine }\end{array}$ & 13,66 & 13,48 & 5,8 & 8,5 & 34 & 16 & & 3,5 & & & 3 \\
\hline 2010 & WINERY 37 & W37.2 & $\begin{array}{c}\text { Macedonia - } \\
\text { LW }\end{array}$ & & 2008 & ROSE & $\begin{array}{l}\text { Dry } \\
\text { wine }\end{array}$ & 13,68 & 13,51 & 4,1 & 5,33 & 82 & 18 & & 3,95 & & & 2,8 \\
\hline 2011 & WINERY 25 & W25.4 & Drama-LW & & 2006 & RED & $\begin{array}{l}\text { Dry } \\
\text { wine }\end{array}$ & 13,93 & 13,74 & 5,49 & 12,9 & 102 & 32 & & 3,46 & & & 3,2 \\
\hline 2011 & WINERY 25 & W25.5 & Drama - LW & & 2006 & RED & $\begin{array}{l}\text { Dry } \\
\text { wine }\end{array}$ & 13,1 & 12,91 & 6,17 & 13,1 & 108 & 32 & & 3,31 & & & 3,2 \\
\hline 2011 & WINERY 25 & W25.2 & Drama-LW & & 2008 & RED & $\begin{array}{l}\text { Dry } \\
\text { wine }\end{array}$ & 13,59 & 13,38 & 5,62 & 12,37 & 102 & 34 & & 3,44 & & & 2,98 \\
\hline 2011 & WINERY 25 & W25.6 & $\begin{array}{c}\text { PGI } \\
\text { Macedonia }\end{array}$ & & 2010 & WHITE & $\begin{array}{l}\text { Dry } \\
\text { wine }\end{array}$ & 12,23 & 12,01 & 5,9 & 6,99 & 102 & 15 & & 3,12 & & & 3,7 \\
\hline 2011 & WINERY 25 & W25.7 & $\begin{array}{c}\text { PGI } \\
\text { Macedonia }\end{array}$ & & 2009 & RED & $\begin{array}{l}\text { Dry } \\
\text { wine }\end{array}$ & 13,69 & 13,49 & 5,8 & 10,73 & 132 & 35 & & 3,4 & & & 3,4 \\
\hline 2011 & WINERY 25 & W25.8 & PGI Paggaio & & 2010 & WHITE & $\begin{array}{l}\text { Dry } \\
\text { wine }\end{array}$ & 13,64 & 13,41 & 6,7 & 7,09 & 134 & 28 & & 3,22 & & & 3,8 \\
\hline 2011 & WINERY 25 & W25.1 & PGI Drama & & 2010 & WHITE & $\begin{array}{l}\text { Dry } \\
\text { wine }\end{array}$ & 12,96 & 12,84 & 6,3 & 9 & 159 & 43 & & 3,27 & & & 2,1 \\
\hline 2011 & WINERY 25 & W25.9 & PGI Drama & & 2009 & WHITE & $\begin{array}{l}\text { Dry } \\
\text { wine }\end{array}$ & 12,82 & 12,7 & 5,9 & 9,4 & 124 & 26 & & 3,21 & & & 2,08 \\
\hline 2011 & WINERY 25 & W25.10 & $\begin{array}{c}\text { PGI } \\
\text { Macedonia }\end{array}$ & & 2009 & RED & $\begin{array}{c}\text { Dry } \\
\text { wine }\end{array}$ & 13,35 & 13,08 & 5,8 & 9,5 & 86 & 35 & & 3,68 & & & 4,5 \\
\hline 2011 & WINERY 25 & W25.5 & PGI Drama & & 2007 & RED & $\begin{array}{l}\text { Dry } \\
\text { wine }\end{array}$ & 14,05 & 13,88 & 5,5 & 12,3 & 92 & 32 & & 3,65 & & & 2,8 \\
\hline 2011 & WINERY 25 & W25.11 & PGI Agora & & 2009 & RED & $\begin{array}{l}\text { Dry } \\
\text { wine }\end{array}$ & 13,35 & 13,2 & 5,8 & 7,7 & 94 & 3,92 & & 3,49 & & & 2,6 \\
\hline 2011 & WINERY 29 & W29.1 & Drama - LW & & 2008 & RED & $\begin{array}{l}\text { Dry } \\
\text { wine }\end{array}$ & 13,92 & 13,77 & 4,8 & 11,9 & 72 & 21 & & 3,72 & & & 2,6 \\
\hline 2011 & WINERY 29 & W29.2 & Drama - LW & & 2010 & WHITE & $\begin{array}{l}\text { Dry } \\
\text { wine }\end{array}$ & 13,84 & 13,68 & 5,8 & 10,5 & 78,1 & 17,9 & & 3,34 & & & 2,6 \\
\hline 2011 & WINERY 13 & W13.1 & Drama - LW & & 2008 & RED & $\begin{array}{l}\text { Dry } \\
\text { wine }\end{array}$ & 14,15 & 13,97 & 5,2 & 12,7 & 102 & 32 & & 3,63 & & & 3 \\
\hline 2011 & WINERY 13 & W13.2 & Drama - LW & & 2010 & WHITE & $\begin{array}{l}\text { Dry } \\
\text { wine }\end{array}$ & 13,56 & 13,46 & 5,3 & 7,1 & 102 & 49 & & 3,3 & & & 1,6 \\
\hline 2011 & WINERY 13 & W13.3 & Drama - LW & & 2010 & ROSE & $\begin{array}{l}\text { Dry } \\
\text { wine }\end{array}$ & 14,18 & 14,07 & 5,3 & 10,3 & 116 & 38 & & 3,29 & & & 1,8 \\
\hline 2011 & WINERY 39 & W39.1 & Drama - LW & & 2010 & WHITE & $\begin{array}{l}\text { Dry } \\
\text { wine }\end{array}$ & 12,01 & 11,78 & 6 & 4,45 & 127 & 25,6 & & 3,32 & & & 3,8 \\
\hline
\end{tabular}




\begin{tabular}{|c|c|c|c|c|c|c|c|c|c|c|c|c|c|c|}
\hline 2011 & WINERY 39 & W39.1 & PGI Drama & 2010 & WHITE & $\begin{array}{c}\text { Dry } \\
\text { wine }\end{array}$ & 12,32 & 12,19 & 5,81 & 4,8 & 122 & 29 & 3,34 & 2,25 \\
\hline 2011 & WINERY 17 & W17.1 & PGI Drama & 2010 & WHITE & $\begin{array}{c}\text { Dry } \\
\text { wine }\end{array}$ & 12,87 & 12,74 & 6 & 10,9 & 121 & 29 & 3,38 & 2,2 \\
\hline 2011 & WINERY 17 & W17.2 & Drama - LW & 2007 & RED & $\begin{array}{l}\text { Dry } \\
\text { wine }\end{array}$ & 13,76 & 13,6 & 5,6 & 12,2 & 112 & 35 & 3,57 & 2,7 \\
\hline 2011 & WINERY 17 & W17.3 & Drama - LW & 2009 & WHITE & $\begin{array}{c}\text { Dry } \\
\text { wine }\end{array}$ & 13,24 & 13,13 & 5,8 & 7,49 & 132 & 47 & 3,3 & 1,89 \\
\hline 2011 & WINERY 5 & W5.1 & Drama - LW & 2008 & RED & $\begin{array}{l}\text { Dry } \\
\text { wine }\end{array}$ & 15,45 & 15,31 & 5,1 & 12,1 & 124 & 32 & 3,94 & 2,3 \\
\hline 2011 & WINERY 5 & W5.2 & Drama - LW & 2006 & RED & $\begin{array}{c}\text { Dry } \\
\text { wine }\end{array}$ & 14,78 & 14,63 & 4,6 & 12 & 88 & 29 & 3,99 & 2,5 \\
\hline 2011 & WINERY 5 & W5.3 & Drama - LW & 2010 & WHITE & $\begin{array}{c}\text { Dry } \\
\text { wine }\end{array}$ & 13,55 & 13,46 & 5,1 & 7,95 & 96 & 51 & 3,57 & 1,5 \\
\hline 2011 & WINERY 25 & W25.4 & Drama - LW & 2006 & RED & $\begin{array}{l}\text { Dry } \\
\text { wine }\end{array}$ & 13,93 & 13,74 & 5,49 & 12,9 & 102 & 32 & 3,46 & 3,2 \\
\hline 2011 & WINERY 25 & W25.5 & Drama - LW & 2006 & RED & $\begin{array}{c}\text { Dry } \\
\text { wine }\end{array}$ & 13,1 & 12,91 & 6,17 & 13,1 & 108 & 32 & 3,31 & 3,2 \\
\hline 2011 & WINERY 25 & W25.2 & PGI Drama & 2008 & RED & $\begin{array}{l}\text { Dry } \\
\text { wine }\end{array}$ & 13,59 & 13,38 & 5,62 & 12,37 & 102 & 34 & 3,44 & 2,98 \\
\hline 2011 & WINERY 37 & W37.3 & $\begin{array}{l}\text { Macedonia - } \\
\text { LW }\end{array}$ & 2009 & WHITE & $\begin{array}{c}\text { Dry } \\
\text { wine }\end{array}$ & 12,58 & 12,39 & 4 & 7,5 & 106 & 20 & 3,62 & 3,2 \\
\hline 2011 & WINERY 37 & W37.2 & $\begin{array}{c}\text { Macedonia - } \\
\text { LW }\end{array}$ & 2009 & ROSE & $\begin{array}{l}\text { Dry } \\
\text { wine }\end{array}$ & 11,89 & 11,79 & 3,9 & 5,8 & 105 & 19 & 3,86 & 1,6 \\
\hline 2012 & WINERY 37 & W37.4 & PGI Drama & 2009 & WHITE & $\begin{array}{c}\text { Dry } \\
\text { wine }\end{array}$ & 12,5 & 12,38 & 4,5 & 11,6 & 193 & 15 & 3,54 & 2,1 \\
\hline 2012 & WINERY 37 & W37.5 & $\begin{array}{c}\text { PGI } \\
\text { Macedonia }\end{array}$ & 2008 & RED & $\begin{array}{c}\text { Dry } \\
\text { wine }\end{array}$ & 13,61 & 13,46 & 5,9 & 13,7 & 28 & 11 & 3,48 & 2,6 \\
\hline 2012 & WINERY 37 & W37.6 & PGI Drama & 2011 & ROSE & $\begin{array}{c}\text { Dry } \\
\text { wine }\end{array}$ & 11,85 & 11,68 & 3,9 & 7,9 & 77 & 10 & 3,88 & 2,9 \\
\hline 2012 & WINERY 37 & W37.7 & $\begin{array}{c}\text { PGI } \\
\text { Macedonia }\end{array}$ & 2011 & WHITE & $\begin{array}{l}\text { Dry } \\
\text { wine }\end{array}$ & 13,11 & 12,95 & 5 & 9,5 & 118 & 126 & 3,4 & 2,7 \\
\hline 2012 & WINERY 37 & W37.9 & PGI Drama & 2008 & RED & $\begin{array}{l}\text { Dry } \\
\text { wine }\end{array}$ & 13,5 & 13,33 & 5,7 & 11 & 52 & 13 & 3,47 & 2,9 \\
\hline 2012 & WINERY 25 & W25.1 & PGI Drama & 2011 & WHITE & $\begin{array}{l}\text { Dry } \\
\text { wine } \\
\text { Semi }\end{array}$ & 13,55 & 13,38 & 6,7 & 7,03 & 160 & & 3,22 & 2,9 \\
\hline 2012 & WINERY 25 & W25.12 & PGI Drama & 2011 & ROSE & $\begin{array}{c}\text { Semi- } \\
\text { dry } \\
\text { wine }\end{array}$ & 13,65 & 13 & 7,4 & 8 & 196 & & 3,13 & 10,9 \\
\hline 2012 & WINERY 25 & W25.2 & PGI Drama & 2009 & RED & $\begin{array}{l}\text { Dry } \\
\text { wine }\end{array}$ & 14,08 & 13,94 & 6,7 & 10,3 & 92 & & 3,24 & 2,3 \\
\hline 2012 & WINERY 25 & W25.9 & PGI Drama & 2010 & WHITE & $\begin{array}{c}\text { Dry } \\
\text { wine }\end{array}$ & 13,35 & 13,21 & 5,8 & 10 & 120 & & 3,14 & 2,3 \\
\hline 2012 & WINERY 25 & W25.4 & PGI Drama & 2006 & RED & $\begin{array}{c}\text { Dry } \\
\text { wine }\end{array}$ & 14,41 & 14,28 & 5,4 & 13,6 & 94 & & 3,47 & 2,2 \\
\hline 2012 & WINERY 25 & W25.8 & PGI Paggaio & 2011 & WHITE & $\begin{array}{c}\text { Dry } \\
\text { wine }\end{array}$ & 13,42 & 13,33 & 7,09 & 7,8 & 125 & & 3,31 & 1,5 \\
\hline 2012 & WINERY 25 & W25.13 & PGI Paggaio & 2009 & RED & $\begin{array}{c}\text { Dry } \\
\text { wine }\end{array}$ & 14,02 & 13,87 & 5,9 & 10,2 & 120 & & 3,45 & 2,6 \\
\hline 2013 & WINERY 25 & W25.14 & & 2007 & RED & $\begin{array}{c}\text { Sweet } \\
\text { wine }\end{array}$ & 20,2 & 12,21 & 6,9 & 16,4 & 96 & 26 & 3,56 & 134,4 \\
\hline
\end{tabular}




\begin{tabular}{|c|c|c|c|c|c|c|c|c|c|c|c|c|c|c|c|c|c|}
\hline 2013 & WINERY 37 & W37.8 & $\begin{array}{c}\text { PGI } \\
\text { Macedonia }\end{array}$ & 2012 & WHITE & $\begin{array}{l}\text { Dry } \\
\text { wine }\end{array}$ & 12,88 & 12,73 & 4,2 & 5,1 & 143 & 42 & & 3,5 & & & 2,5 \\
\hline 2013 & WINERY 37 & W37.7 & $\begin{array}{c}\text { PGI } \\
\text { Macedonia }\end{array}$ & 2012 & WHITE & $\begin{array}{l}\text { Dry } \\
\text { wine }\end{array}$ & 13,27 & 13,05 & 5 & 9,3 & 160 & 40 & & 3,43 & & & 3,7 \\
\hline 2013 & WINERY 37 & W37.6 & PGI Drama & 2012 & ROSE & $\begin{array}{l}\text { Dry } \\
\text { wine }\end{array}$ & 12,6 & 12,5 & 3,7 & 7,3 & 159 & 45 & & 3,8 & & & 1,8 \\
\hline 2014 & WINERY 29 & W29.3 & PGI Drama & 2013 & WHITE & $\begin{array}{c}\text { Dry } \\
\text { wine }\end{array}$ & 12,93 & 12,87 & 5,9 & 5,3 & 116 & 35 & & 3,19 & 0,989 & 20,3 & 1 \\
\hline 2014 & WINERY 5 & W5.4 & PGI Drama & 2013 & ROSE & $\begin{array}{l}\text { Dry } \\
\text { wine }\end{array}$ & 13,91 & 13,79 & 4,7 & 4,1 & 133 & 52 & & 3,39 & 0,989 & 22,2 & 2 \\
\hline 2014 & WINERY 5 & W5.1 & PGI Drama & 2010 & RED & $\begin{array}{l}\text { Dry } \\
\text { wine }\end{array}$ & 15,08 & 14,95 & 4,9 & 9,7 & 117 & 26 & & 3,8 & 0,993 & 34,6 & 2,2 \\
\hline 2014 & WINERY 5 & W5.5 & PGI Drama & 2010 & WHITE & $\begin{array}{l}\text { Dry } \\
\text { wine }\end{array}$ & 12,44 & 12,37 & 6,1 & 5,1 & 127 & 57 & & 3,32 & 0,99 & 19,6 & 1,1 \\
\hline 2015 & WINERY 37 & W37.6 & PGI Drama & 2014 & ROSE & $\begin{array}{l}\text { Dry } \\
\text { wine }\end{array}$ & 12,48 & 12,33 & 4,7 & 4,1 & 128 & 19 & & 3,43 & 0,99 & 20,3 & 2,6 \\
\hline 2015 & WINERY 37 & W37.3 & $\begin{array}{c}\text { PGI } \\
\text { Macedonia }\end{array}$ & 2014 & WHITE & $\begin{array}{l}\text { Dry } \\
\text { wine }\end{array}$ & 12,56 & 12,41 & 4,8 & 4,7 & 134 & 22 & & 3,3 & 0,989 & 18,5 & 2,6 \\
\hline 2015 & WINERY 13 & W13.2 & PGI Drama & 2014 & WHITE & $\begin{array}{l}\text { Dry } \\
\text { wine }\end{array}$ & 12,49 & 12,38 & 4,9 & 3,6 & 98 & 24 & & 3,35 & 0,989 & 19,3 & 1,9 \\
\hline 2015 & WINERY 13 & W13.1 & PGI Drama & 2012 & RED & $\begin{array}{c}\text { Dry } \\
\text { wine }\end{array}$ & 14,51 & 14,24 & 5,3 & 9,4 & 156 & 28 & & 3,57 & 0,992 & 30,5 & 4,5 \\
\hline 2016 & WINERY 25 & W25.1 & PGI Drama & 2015 & WHITE & $\begin{array}{l}\text { Dry } \\
\text { wine }\end{array}$ & 12,22 & 11,98 & 5,6 & 5,3 & 177 & 22 & & 3,32 & 0,992 & 23,7 & 4 \\
\hline 2016 & WINERY 25 & W25.2 & PGI Drama & 2014 & RED & $\begin{array}{l}\text { Dry } \\
\text { wine }\end{array}$ & 14,46 & 14,23 & 5,9 & 10 & 116 & 21 & & 3,56 & 0,993 & 32,8 & 3,8 \\
\hline 2016 & WINERY 28 & W28.1 & PGI Drama & 2013 & RED & $\begin{array}{l}\text { Dry } \\
\text { wine }\end{array}$ & 13,81 & 13,63 & 5,4 & 10,2 & 90,9 & 12,5 & & 3,46 & 0,993 & 32,3 & 3 \\
\hline 2016 & WINERY 29 & W29.4 & PGI Drama & 2012 & RED & $\begin{array}{l}\text { Dry } \\
\text { wine }\end{array}$ & 13,78 & 13,61 & 5 & 12 & 95 & 28 & & 3,75 & 0,994 & 33,6 & 2,9 \\
\hline 2016 & WINERY 17 & W17.4 & PGI Drama & 2013 & RED & $\begin{array}{l}\text { Dry } \\
\text { wine }\end{array}$ & 14,85 & 14,62 & 5 & 11,9 & 103 & 21 & & 3,62 & 0,992 & 31,3 & 3,8 \\
\hline 2016 & WINERY 17 & W17.5 & $\begin{array}{c}\text { PGI } \\
\text { Macedonia }\end{array}$ & 2015 & WHITE & $\begin{array}{l}\text { Dry } \\
\text { wine }\end{array}$ & 12,01 & 11,91 & 6,3 & 7,9 & 120 & 47 & & 3,02 & 0,99 & 20,1 & 1,7 \\
\hline 2017 & WINERY 5 & W5.4 & PGI Drama & 2017 & ROSE & $\begin{array}{c}\text { Dry } \\
\text { wine }\end{array}$ & 13,14 & 13 & 5,4 & 9,6 & 137 & 69 & 4 & 3,28 & 0,989 & 20,9 & 2,3 \\
\hline 2017 & WINERY 5 & W5.5 & PGI Drama & 2016 & WHITE & $\begin{array}{l}\text { Dry } \\
\text { wine }\end{array}$ & 13,49 & 13,35 & 6,2 & 9,1 & 138 & 54 & 8 & 3,2 & 0,989 & 20,9 & 2,4 \\
\hline 2017 & WINERY 5 & W5.5 & PGI Drama & 2017 & WHITE & $\begin{array}{l}\text { Dry } \\
\text { wine }\end{array}$ & 13,11 & 12,92 & 5,4 & 10 & 136 & 67 & 9 & 3,43 & 0,991 & 22,4 & 3,2 \\
\hline 2017 & WINERY 5 & W5.2 & PGI Drama & 2015 & RED & $\begin{array}{l}\text { Dry } \\
\text { wine }\end{array}$ & 15,28 & 15,05 & 4,5 & 11,1 & 87 & 21 & 3 & 3,76 & 0,992 & 32,8 & 3,9 \\
\hline 2017 & WINERY 5 & W5.6 & PGI Drama & 2015 & RED & $\begin{array}{l}\text { Dry } \\
\text { wine }\end{array}$ & 14,2 & 14,02 & 4,5 & 11,9 & 85 & 33 & 0 & 3,76 & 0,992 & 30,2 & 3 \\
\hline 2017 & WINERY 5 & W5.7 & PGI Drama & 2014 & RED & $\begin{array}{l}\text { Dry } \\
\text { wine }\end{array}$ & 14,15 & 13,95 & 4,5 & 12,3 & 63 & 15 & 0 & 3,68 & 0,991 & 28,9 & 3,3 \\
\hline 2017 & WINERY 5 & W5.8 & PGI Attiki & 2014 & RED & $\begin{array}{l}\text { Dry } \\
\text { wine }\end{array}$ & 14,7 & 14,49 & 5,2 & 11,7 & 84 & 21 & 2 & 3,67 & 0,993 & 35,2 & 3,5 \\
\hline 2017 & WINERY 5 & W5.9 & PGI Drama & 2017 & WHITE & $\begin{array}{l}\text { Dry } \\
\text { wine }\end{array}$ & 13,45 & 13,34 & 5,1 & 4,2 & 114 & 37 & 4 & 3,4 & 0,989 & 20,9 & 1,8 \\
\hline 2017 & WINERY 5 & W5.10 & PGI Drama & 2017 & WHITE & $\begin{array}{c}\text { Dry } \\
\text { wine }\end{array}$ & 13,04 & 12,83 & 3,5 & 3,8 & 133 & 72 & 2 & 3,37 & 0,99 & 22,4 & 3,6 \\
\hline
\end{tabular}




\begin{tabular}{|c|c|c|c|c|c|c|c|c|c|c|c|c|c|c|c|c|c|c|}
\hline 2017 & WINERY 5 & W5.11 & $\begin{array}{l}\text { Macedonia - } \\
\text { LW }\end{array}$ & & 2011 & RED & $\begin{array}{c}\text { Dry } \\
\text { wine }\end{array}$ & 15,08 & 14,91 & 4,7 & 10,4 & 98 & 16 & 5 & 3,57 & 0,992 & 32,8 & 2,9 \\
\hline 2017 & WINERY 5 & W5.11 & $\begin{array}{l}\text { Macedonia - } \\
\text { LW }\end{array}$ & & 2001 & RED & $\begin{array}{l}\text { Dry } \\
\text { wine }\end{array}$ & 13,24 & 13,1 & 4,3 & 6,6 & 77 & 16 & 2 & 3,66 & 0,992 & 27,1 & 2,3 \\
\hline 2017 & WINERY 5 & W5.9 & PGI Drama & & 2017 & WHITE & $\begin{array}{l}\text { Dry } \\
\text { wine }\end{array}$ & 13,21 & 13,03 & 5,1 & 4,4 & 136 & 61 & 2 & 3,38 & 0,99 & 22,2 & 3 \\
\hline 2017 & WINERY 5 & W5.12 & PGI Drama & & 2016 & WHITE & $\begin{array}{c}\text { Dry } \\
\text { wine }\end{array}$ & 13,16 & 13,01 & 5,2 & 2,7 & 122 & 60 & 0,5 & 3,21 & 0,989 & 19,8 & 2,5 \\
\hline 2017 & WINERY 5 & W5.12 & PGI Drama & & 2016 & WHITE & $\begin{array}{l}\text { Dry } \\
\text { wine }\end{array}$ & 13,34 & 13,13 & 5,1 & 4,5 & 134 & 61 & 2 & 3,36 & 0,99 & 22,2 & 3,6 \\
\hline 2017 & WINERY 5 & W5.6 & PGI Drama & & 2013 & RED & $\begin{array}{l}\text { Dry } \\
\text { wine }\end{array}$ & 14,41 & 14,23 & 4,8 & 16,3 & 90 & 32 & 0,5 & 3,81 & 0,992 & 30,5 & 3,1 \\
\hline 2017 & WINERY 5 & W5.13 & PGI Drama & & 2015 & RED & $\begin{array}{c}\text { Dry } \\
\text { wine }\end{array}$ & 14,2 & 14,05 & 4,8 & 19,8 & 97 & 21 & 1 & 3,85 & 0,991 & 28,7 & 2,6 \\
\hline 2017 & WINERY 5 & W5.11 & $\begin{array}{l}\text { Macedonia - } \\
\text { LW }\end{array}$ & & 1998 & RED & $\begin{array}{l}\text { Dry } \\
\text { wine }\end{array}$ & 12,96 & 12,85 & 4,4 & 7,8 & 93 & 18 & 5 & 3,63 & 0,991 & 25,5 & 1,9 \\
\hline 2017 & WINERY 5 & W5.14 & PGI Drama & & 2011 & RED & $\begin{array}{l}\text { Dry } \\
\text { wine }\end{array}$ & 14,96 & 14,76 & 5,1 & 10,9 & 84 & 20 & 1 & 3,65 & 0,992 & 31,8 & 3,3 \\
\hline 2017 & WINERY 5 & W5.7 & PGI Drama & & 2013 & RED & $\begin{array}{l}\text { Dry } \\
\text { wine }\end{array}$ & 15,32 & 15,12 & 4,9 & 14,7 & 60 & 14 & 0,3 & 3,82 & 0,993 & 36,2 & 3,4 \\
\hline 2017 & WINERY 5 & W5.8 & PGI Attiki & & 2014 & RED & $\begin{array}{c}\text { Dry } \\
\text { wine }\end{array}$ & 14,54 & 14,38 & 5,1 & 12,3 & 57 & 12 & 2 & 3,75 & 0,993 & 33,3 & 2,7 \\
\hline 2017 & WINERY 5 & W5.2 & PGI Drama & & 2014 & RED & $\begin{array}{l}\text { Dry } \\
\text { wine }\end{array}$ & 14,41 & 14,23 & 4,5 & 11,3 & 68 & 12 & 2 & 3,78 & 0,992 & 31,3 & 3 \\
\hline 2017 & WINERY 5 & W5.15 & PGI Drama & & 2013 & RED & $\begin{array}{l}\text { Dry } \\
\text { wine }\end{array}$ & 14,36 & 14,17 & 5 & 10,4 & 82 & 20 & 0,1 & 3,56 & 0,992 & 30 & 3,2 \\
\hline 2018 & WINERY 67 & W67.1 & PGI Drama & & 2017 & RED & $\begin{array}{l}\text { Dry } \\
\text { wine }\end{array}$ & 13,72 & 13,42 & 4,68 & 7,8 & 93 & 17 & 4 & 3,79 & 0,994 & 34,6 & 5,1 \\
\hline 2018 & WINERY 37 & W37.1 & $\begin{array}{l}\text { Macedonia - } \\
\text { LW }\end{array}$ & & 2010 & RED & $\begin{array}{l}\text { Dry } \\
\text { wine }\end{array}$ & 13,49 & 13,29 & 4,49 & 10 & 48 & 7 & 7 & 3,79 & 0,993 & 30,3 & 3,3 \\
\hline 2018 & WINERY 5 & W5.8 & PGI Attiki & & 2015 & RED & $\begin{array}{l}\text { Dry } \\
\text { wine }\end{array}$ & 14,7 & 14,47 & 5,14 & 11,6 & 59 & 11 & 2 & 3,74 & 0,993 & 34,9 & 3,9 \\
\hline 2018 & WINERY 5 & W5.12 & PGI Drama & & 2017 & WHITE & $\begin{array}{l}\text { Dry } \\
\text { wine }\end{array}$ & 13,56 & 13,43 & 4,95 & 4,4 & 147 & 66 & 2 & 3,43 & 0,989 & 22,4 & 2,2 \\
\hline 2018 & WINERY 5 & W5.15 & PGI Drama & & 2015 & RED & $\begin{array}{l}\text { Dry } \\
\text { wine }\end{array}$ & 14,52 & 14,33 & 4,88 & 15,4 & 73 & 24 & 0 & 3,77 & 0,992 & 31,5 & 3,2 \\
\hline 2018 & WINERY 5 & W5.10 & PGI Drama & & 2017 & WHITE & $\begin{array}{l}\text { Dry } \\
\text { wine }\end{array}$ & 13,2 & 12,99 & 4,96 & 3,8 & 119 & 63 & 0 & 3,4 & 0,99 & 22,4 & 3,6 \\
\hline 2018 & WINERY 5 & W5.13 & PGI Drama & & 2017 & RED & $\begin{array}{l}\text { Dry } \\
\text { wine }\end{array}$ & 14,17 & 14,03 & 4,44 & 10 & 77 & 29 & 1 & 3,96 & 0,993 & 34,4 & 2,4 \\
\hline 2018 & WINERY 5 & W5.9 & PGI Drama & & 2017 & WHITE & $\begin{array}{l}\text { Dry } \\
\text { wine }\end{array}$ & 13,56 & 13,41 & 4,87 & 4,7 & 145 & 65 & 4 & 3,45 & 0,99 & 22,7 & 2,5 \\
\hline 2018 & WINERY 5 & W5.16 & PGI Drama & & 2017 & WHITE & $\begin{array}{l}\text { Dry } \\
\text { wine }\end{array}$ & 13,14 & 12,84 & 5,44 & 4 & 114 & 45 & 3 & 3,07 & 0,99 & 22,2 & 5 \\
\hline 2018 & WINERY 5 & W5.17 & PGI Drama & & 2017 & ROSE & $\begin{array}{l}\text { Dry } \\
\text { wine }\end{array}$ & 13,19 & 12,99 & 5,09 & 4,2 & 115 & 52 & 7 & 3,33 & 0,99 & 22,4 & 3,4 \\
\hline 2018 & WINERY 5 & W5.1 & PGI Drama & & 2017 & RED & $\begin{array}{c}\text { Dry } \\
\text { wine }\end{array}$ & 13,6 & 12,79 & 6,38 & 6,1 & 123 & 54 & 0 & 3,28 & 0,991 & 25,5 & 4,6 \\
\hline 2018 & WINERY 5 & W5.3 & PGI Drama & & 2017 & WHITE & $\begin{array}{l}\text { Dry } \\
\text { wine }\end{array}$ & 13,2 & 12,97 & 5,19 & 5,2 & 126 & 58 & 0 & 3,42 & 0,991 & 24 & 3,8 \\
\hline 2018 & WINERY 25 & W25.15 & & Wine tanks & 2016 & RED & $\begin{array}{c}\text { Dry } \\
\text { wine }\end{array}$ & 13,34 & 13,15 & 4,3 & 7,9 & 112 & 28 & 11 & 3,77 & 0,992 & 29,2 & 3,2 \\
\hline
\end{tabular}




\begin{tabular}{|c|c|c|c|c|c|c|c|c|c|c|c|c|c|c|c|c|c|c|}
\hline 2018 & WINERY 39 & W39.2 & PGI Drama & & 2014 & RED & $\begin{array}{c}\text { Dry } \\
\text { wine }\end{array}$ & 12,83 & 12,71 & 5,3 & 8,7 & 135 & 22 & 10 & 3,44 & 0,992 & 26,6 & 2 \\
\hline 2018 & WINERY 39 & W39.3 & PGI Drama & & 2017 & WHITE & $\begin{array}{c}\text { Dry } \\
\text { wine }\end{array}$ & 11,93 & 11,81 & 4,9 & 2,9 & 99 & 20 & 2 & 3,3 & 0,991 & 20,6 & 2 \\
\hline 2018 & WINERY 60 & W60.1 & & & 2016 & RED & $\begin{array}{l}\text { Dry } \\
\text { wine }\end{array}$ & 12,86 & 12,68 & 5,7 & 7,6 & 127 & 21 & 6 & 3,45 & 0,993 & 29,4 & 3 \\
\hline 2018 & WINERY 13 & W13.3 & PGI Drama & & 2016 & ROSE & $\begin{array}{c}\text { Dry } \\
\text { wine }\end{array}$ & 13,16 & 13,04 & 5 & 5,5 & 84 & 20 & 3 & 3,2 & 0,989 & 18,8 & 2,1 \\
\hline 2018 & WINERY 13 & W13.1 & PGI Drama & & 2014 & RED & $\begin{array}{l}\text { Dry } \\
\text { wine }\end{array}$ & 14,88 & 14,7 & 5,4 & 7,6 & 120 & 22 & 2 & 3,64 & 0,992 & 32,3 & 3 \\
\hline 2018 & WINERY 5 & W5.13 & PGI Drama & & 2015 & RED & $\begin{array}{c}\text { Dry } \\
\text { wine }\end{array}$ & 14,13 & 13,95 & 4,5 & 12,7 & 93 & 36 & 1 & 3,83 & 0,992 & 31,5 & 3 \\
\hline 2018 & WINERY 5 & W5.12 & PGI Drama & & 2017 & WHITE & $\begin{array}{c}\text { Dry } \\
\text { wine }\end{array}$ & 13,06 & 12,97 & 5 & 4,3 & 124 & 61 & 7 & 3,46 & 0,989 & 20,9 & 1,5 \\
\hline 2018 & WINERY 5 & W5.12 & PGI Drama & & 2017 & WHITE & $\begin{array}{l}\text { Dry } \\
\text { wine }\end{array}$ & 13,4 & 13,28 & 5 & 5,3 & 158 & 74 & 4 & 3,44 & 0,989 & 21,9 & 2 \\
\hline 2018 & WINERY 5 & W5.17 & PGI Drama & & 2017 & ROSE & $\begin{array}{c}\text { Dry } \\
\text { wine }\end{array}$ & 13,14 & 13 & 5,3 & 5,1 & 133 & 66 & 3 & 3,31 & 0,989 & 22,2 & 2,4 \\
\hline 2018 & WINERY 5 & W5.5 & PGI Drama & & 2016 & WHITE & $\begin{array}{l}\text { Dry } \\
\text { wine }\end{array}$ & 13,43 & 13,3 & 6 & 9,3 & 134 & 51 & 3 & 3,25 & 0,989 & 21,6 & 2,2 \\
\hline 2018 & WINERY 5 & W5.12 & PGI Drama & & 2017 & WHITE & $\begin{array}{c}\text { Dry } \\
\text { wine }\end{array}$ & 13,02 & 12,8 & 5,4 & 5,3 & 132 & 62 & 3 & 3,45 & 0,995 & 23,5 & 3,7 \\
\hline 2019 & WINERY 62 & W62.1 & & Wine tanks & 2018 & WHITE & $\begin{array}{c}\text { Dry } \\
\text { wine }\end{array}$ & 12,51 & 12,38 & 4,99 & 4,5 & 140 & 21 & 2 & 3,66 & 0,99 & 22,4 & 2,2 \\
\hline 2019 & WINERY 25 & W25.1 & PGI Drama & & 2018 & WHITE & $\begin{array}{c}\text { Dry } \\
\text { wine }\end{array}$ & 12,63 & 12,49 & 4,88 & 4,2 & 168 & 11 & 1 & 3,47 & 0,989 & 20,1 & 2,4 \\
\hline 2019 & WINERY 25 & W25.12 & PGI Drama & & 2018 & ROSE & $\begin{array}{l}\text { Semi- } \\
\text { dry } \\
\text { wine }\end{array}$ & 14,02 & 13,08 & 6,64 & 6,5 & 228 & 35 & 56 & 3,31 & 0,996 & 37,8 & 15,9 \\
\hline 2019 & WINERY 25 & W25.2 & PGI Drama & & 2016 & RED & $\begin{array}{l}\text { Dry } \\
\text { wine }\end{array}$ & 14,96 & 14,69 & 4,94 & 10,8 & 78 & 24 & 0 & 3,67 & 0,992 & 33,1 & 4,5 \\
\hline 2019 & WINERY 5 & W5.8 & PGI Attiki & & 2016 & RED & $\begin{array}{c}\text { Dry } \\
\text { wine }\end{array}$ & 14,59 & 14,39 & 5,12 & 14 & 91 & 19 & 1 & 3,8 & 0,994 & 37,5 & 3,3 \\
\hline 2019 & WINERY 5 & W5.6 & PGI Drama & & 2017 & RED & $\begin{array}{c}\text { Dry } \\
\text { wine }\end{array}$ & 13,66 & 13,48 & 5,03 & 9,2 & 86 & 25 & 2 & 3,86 & 0,994 & 33,6 & 3 \\
\hline 2019 & WINERY 5 & W5.9 & PGI Drama & & 2018 & WHITE & $\begin{array}{c}\text { Dry } \\
\text { wine }\end{array}$ & 13,52 & 13,37 & 5,18 & 6,6 & 144 & 59 & 2 & 3,56 & 0,989 & 22,4 & 2,6 \\
\hline 2019 & WINERY 5 & W5.15 & PGI Drama & & 2017 & RED & $\begin{array}{l}\text { Dry } \\
\text { wine }\end{array}$ & 14,15 & 13,98 & 4,49 & 14,7 & 66 & 14 & 5 & 3,89 & 0,992 & 31 & 2,9 \\
\hline 2019 & WINERY 5 & W5.10 & PGI Drama & & 2018 & WHITE & $\begin{array}{l}\text { Dry } \\
\text { wine }\end{array}$ & 13,01 & 12,83 & 5,69 & 3,6 & 131 & 58 & 4 & 3,31 & 0,989 & 21,6 & 3,1 \\
\hline 2019 & WINERY 5 & W5.13 & PGI Drama & & 2017 & RED & $\begin{array}{c}\text { Dry } \\
\text { wine }\end{array}$ & 13,84 & 13,67 & 5,01 & 9,3 & 82 & 24 & 3 & 3,85 & 0,993 & 33,6 & 2,9 \\
\hline 2019 & WINERY 5 & W5.12 & PGI Drama & & 2018 & WHITE & $\begin{array}{c}\text { Dry } \\
\text { wine }\end{array}$ & 12,94 & 12,76 & 5,3 & 4,7 & 143 & 60 & 13 & 3,52 & 0,99 & 21,6 & 3 \\
\hline 2019 & WINERY 5 & W5.18 & PGI Drama & & 2018 & WHITE & $\begin{array}{c}\text { Dry } \\
\text { wine }\end{array}$ & 13,49 & 13,34 & 5,2 & 6,7 & 140 & 60 & 5 & 3,54 & 0,989 & 21,9 & 2,6 \\
\hline 2019 & WINERY 5 & W5.16 & PGI Drama & & 2018 & WHITE & $\begin{array}{c}\text { Dry } \\
\text { wine }\end{array}$ & 13,09 & 12,85 & 6,03 & 4,3 & 137 & 64 & 1 & 3,29 & 0,99 & 22,2 & 4 \\
\hline 2019 & WINERY 5 & W5.17 & PGI Drama & & 2018 & ROSE & $\begin{array}{c}\text { Dry } \\
\text { wine }\end{array}$ & 13,17 & 12,97 & 5,64 & 5,5 & 136 & 63 & 0 & 3,38 & 0,99 & 22,4 & 3,3 \\
\hline
\end{tabular}




\begin{tabular}{|c|c|c|c|c|c|c|c|c|c|c|c|c|c|c|c|c|c|}
\hline 2019 & WINERY 5 & W5.2 & PGI Drama & 2016 & RED & $\begin{array}{c}\text { Dry } \\
\text { wine }\end{array}$ & 14,7 & 14,5 & 4,74 & 14,4 & 69 & 18 & 8 & 3,81 & 0,992 & 31,5 & 3,4 \\
\hline 2019 & WINERY 5 & W5.5 & PGI Drama & 2017 & WHITE & $\begin{array}{c}\text { Dry } \\
\text { wine }\end{array}$ & 12,76 & 12,51 & 6,34 & 6,5 & 110 & 52 & 11 & 3,39 & 0,991 & 24 & 4,2 \\
\hline 2019 & WINERY 5 & W5.7 & PGI Drama & 2016 & RED & $\begin{array}{c}\text { Dry } \\
\text { wine }\end{array}$ & 15,18 & 14,95 & 4,98 & 9,8 & 78 & 17 & 3 & 3,71 & 0,992 & 34,1 & 3,8 \\
\hline 2019 & WINERY 5 & W5.3 & PGI Drama & 2018 & WHITE & $\begin{array}{c}\text { Dry } \\
\text { wine }\end{array}$ & 13,14 & 12,94 & 5,83 & 5,2 & 139 & 65 & 1 & 3,5 & 0,99 & 23,2 & 3,4 \\
\hline
\end{tabular}

Table B2. Samples from Regional District (Prefecture) of Evros

\begin{tabular}{|c|c|c|c|c|c|c|c|c|c|c|c|c|c|c|c|c|c|c|}
\hline $\begin{array}{l}\text { Year of } \\
\text { analysis }\end{array}$ & WINERY & WINE & $\begin{array}{c}\text { Wine } \\
\text { Category }\end{array}$ & $\begin{array}{c}\text { Wine } \\
\text { container } \\
\text { (except } \\
\text { bottles) }\end{array}$ & $\begin{array}{l}\text { Year of } \\
\text { Harvest }\end{array}$ & Colour & $\begin{array}{l}\text { Type of } \\
\text { Wine }\end{array}$ & $\begin{array}{c}\text { Total } \\
\text { Alcoholic } \\
\text { Strength } \\
\text { (\% Vol. } \\
200 \text { C) }\end{array}$ & $\begin{array}{c}\text { Obtained } \\
\text { Alcoholic } \\
\text { Strength } \\
(\% \text { Vol. } \\
200 \text { C) }\end{array}$ & $\begin{array}{c}\text { Total } \\
\text { Acidity } \\
\text { (g/l } \\
\text { tartaric } \\
\text { acid) }\end{array}$ & $\begin{array}{l}\text { Volatile } \\
\text { Acidity } \\
\text { (meq/l) }\end{array}$ & $\begin{array}{c}\text { Total } \\
\text { Sulphur } \\
(\mathrm{mg} / \mathrm{l})\end{array}$ & $\begin{array}{c}\text { Free } \\
\text { Sulphur } \\
(\mathbf{m g} / \mathbf{l})\end{array}$ & $\begin{array}{c}\text { Sorbic } \\
\text { Acid } \\
(\mathrm{mg} / \mathrm{l})\end{array}$ & pH & $\begin{array}{c}\text { Density of } \\
\text { Wine } \\
(\mathrm{g} / \mathrm{ml})\end{array}$ & \begin{tabular}{|c|} 
Total \\
Wine Solid \\
Residues \\
or Total \\
Dry \\
Extract of \\
Wine $(\mathrm{g} / \mathrm{l})$ \\
\end{tabular} & $\begin{array}{c}\text { Residual } \\
\text { Sugars } \\
\text { (g/l) }\end{array}$ \\
\hline 2012 & \begin{tabular}{|c} 
WINERY \\
7
\end{tabular} & W7.1 & & & 2012 & WHITE & $\begin{array}{l}\text { Semi-dry } \\
\text { wine }\end{array}$ & 13,19 & 12,94 & 4 & 5,9 & 114 & 18 & & 3,5 & & & 4,2 \\
\hline 2012 & $\begin{array}{c}\text { WINERY } \\
7\end{array}$ & W7.2 & $\begin{array}{l}\text { Thraki - } \\
\text { LW }\end{array}$ & & 2008 & RED & Dry wine & 13,52 & 13,41 & 3,8 & 15,4 & 80 & 18 & & 3,98 & & & 1,9 \\
\hline 2014 & $\begin{array}{c}\text { WINERY } \\
7\end{array}$ & W7.3 & PGI Evros & & 2010 & WHITE & Dry wine & 12,76 & 12,5 & 3,9 & 5,2 & 106 & 12 & & 3,5 & 0,99 & 20,6 & 4,3 \\
\hline 2015 & $\begin{array}{c}\text { WINERY } \\
3\end{array}$ & W3.1 & & & 2014 & WHITE & Dry wine & 12,45 & 12,3 & 7,2 & 3,1 & 172 & 22 & & 3,18 & 0,993 & 27,1 & 2,5 \\
\hline 2015 & $\begin{array}{c}\text { WINERY } \\
3\end{array}$ & W3.2 & & & 2014 & RED & Dry wine & 12,45 & 12,3 & 4,8 & 6,3 & 77 & 14 & & 3,49 & 0,991 & 24,2 & 2,6 \\
\hline 2016 & $\begin{array}{c}\text { WINERY } \\
24\end{array}$ & W24.1 & PGI Thraki & & 2015 & WHITE & Dry wine & 13,18 & 13,03 & 5,5 & 4,2 & 119 & 40 & & 3,37 & 0,99 & 21,6 & 2,5 \\
\hline 2016 & $\begin{array}{c}\text { WINERY } \\
24\end{array}$ & W24.2 & PGI Thraki & & 2014 & RED & Dry wine & 12,64 & 12,49 & 5 & 12,2 & 120 & 28 & & 3,7 & 0,994 & 30,7 & 2,6 \\
\hline 2016 & $\begin{array}{c}\text { WINERY } \\
7\end{array}$ & W7.2 & PGI Thraki & & 2014 & RED & Dry wine & 13,56 & 13,31 & 4,7 & 8,6 & 138 & 13 & & 3,78 & 0,994 & 33,9 & 4,2 \\
\hline 2016 & $\begin{array}{c}\text { WINERY } \\
24\end{array}$ & W24.3 & PGI Thraki & & 2014 & RED & Dry wine & 14,09 & 13,91 & 5 & 17,1 & 142 & 25 & & 3,81 & 0,993 & 31,5 & 3 \\
\hline 2016 & $\begin{array}{c}\text { WINERY } \\
24\end{array}$ & W24.2 & PGI Thraki & & 2014 & RED & Dry wine & 14,89 & 14,7 & 5 & 9,5 & 140 & 16 & & 3,84 & 0,993 & 35,4 & 3,2 \\
\hline 2016 & $\begin{array}{c}\text { WINERY } \\
33\end{array}$ & W33.1 & & & 2015 & ROSE & Dry wine & 12,68 & 12,58 & 4,3 & 5,5 & 119 & 14 & & 3,57 & 0,989 & 19,6 & 1,6 \\
\hline 2016 & $\begin{array}{c}\text { WINERY } \\
7\end{array}$ & W7.3 & PGI Evros & & 2015 & WHITE & Dry wine & 13,06 & 13,06 & 5,5 & 8,2 & 109 & 55 & & 3,66 & 0,99 & 23,2 & 1,6 \\
\hline 2016 & $\begin{array}{c}\text { WINERY } \\
7\end{array}$ & W7.4 & PGI Evros & & 2016 & WHITE & Dry wine & 12,42 & 12,34 & 5,1 & 6,8 & 64 & 6 & & 3,56 & 0,99 & 21,4 & 1,7 \\
\hline 2016 & $\begin{array}{c}\text { WINERY } \\
24\end{array}$ & W24.4 & PGI Thraki & & 2015 & WHITE & Dry wine & 11,75 & 11,66 & 5 & 4,2 & 80 & 41 & & 3,55 & 0,991 & 20,6 & 1,5 \\
\hline 2016 & $\begin{array}{c}\text { WINERY } \\
9\end{array}$ & W9.1 & & & 2015 & RED & Dry wine & 13,09 & 12,99 & 4,9 & 6,6 & 150 & 24 & & 3,52 & 0,989 & 21,1 & 1,7 \\
\hline 2016 & $\begin{array}{c}\text { WINERY } \\
9\end{array}$ & W9.2 & & & 2015 & RED & Dry wine & 12,93 & 12,85 & 4,5 & 6,4 & 209 & 6 & & 3,37 & 0,989 & 18,3 & 1,4 \\
\hline 2016 & $\begin{array}{c}\text { WINERY } \\
47\end{array}$ & W47.1 & & & 2015 & RED & Dry wine & 13,3 & 13,12 & 4,4 & 14,5 & 132 & 39 & & 3,88 & 0,993 & 30 & 3 \\
\hline
\end{tabular}




\begin{tabular}{|c|c|c|c|c|c|c|c|c|c|c|c|c|c|c|c|c|c|c|}
\hline 2016 & $\begin{array}{c}\text { WINERY } \\
36\end{array}$ & W36.1 & & & 2015 & RED & Dry wine & 13,64 & 13,5 & 5,1 & 11,3 & 93 & 12 & & 3,63 & 0,993 & 30,5 & 2,4 \\
\hline 2017 & $\begin{array}{c}\text { WINERY } \\
20\end{array}$ & W20.1 & & & 2016 & RED & $\begin{array}{c}\text { Semi-sweet } \\
\text { wine }\end{array}$ & 12,79 & 11,33 & 4,4 & 15 & 73 & 19 & 665 & 3,81 & 1,005 & 56,6 & 24,6 \\
\hline 2017 & $\begin{array}{c}\text { WINERY } \\
20\end{array}$ & W20.2 & & & 2017 & WHITE & Dry wine & 11,89 & 11,82 & 5,6 & 5,6 & 113 & 11 & 1 & 3,27 & 0,99 & 18,8 & 1,2 \\
\hline 2017 & $\begin{array}{c}\text { WINERY } \\
3\end{array}$ & W3.3 & $\begin{array}{c}\text { Traditional } \\
\text { Appellation, } \\
\text { Retsina }\end{array}$ & & 2017 & WHITE & Dry wine & 12,17 & 12,06 & 4,6 & 4,9 & 161 & 42 & 3 & 3,4 & 0,991 & 21,6 & 1,9 \\
\hline 2017 & $\begin{array}{c}\text { WINERY } \\
3\end{array}$ & W3.1 & & & 2017 & WHITE & Dry wine & 13,06 & 12,88 & 5,1 & 4,8 & 137 & 31 & 3 & 3,45 & 0,992 & 26,3 & 3,1 \\
\hline 2017 & $\begin{array}{c}\text { WINERY } \\
3\end{array}$ & W3.4 & & & 2015 & WHITE & Dry wine & 12,98 & 12,85 & 5,1 & 6,3 & 81 & 18 & 1 & 3,37 & 0,99 & 22,7 & 2,2 \\
\hline 2018 & $\begin{array}{c}\text { WINERY } \\
20\end{array}$ & W20.3 & & Wine tanks & 2017 & RED & Dry wine & 13,66 & 13,49 & 5,3 & 7 & 102 & 21 & 0 & 3,64 & 0,993 & 30,7 & 2,9 \\
\hline 2018 & $\begin{array}{c}\text { WINERY } \\
20\end{array}$ & W20.2 & & Wine tanks & 2017 & WHITE & Dry wine & 12,4 & 11,95 & 5,2 & 3,6 & 73 & 9 & 0 & 3,37 & 0,991 & 21,1 & 1,5 \\
\hline 2018 & $\begin{array}{c}\text { WINERY } \\
3\end{array}$ & W3.4 & & & 2017 & WHITE & Dry wine & 12,03 & 11,74 & 5,1 & 4,6 & 123 & 20 & 0 & 3,32 & 0,992 & 23,2 & 4,9 \\
\hline 2018 & $\begin{array}{c}\text { WINERY } \\
3\end{array}$ & W3.5 & & & 2017 & ROSE & $\begin{array}{c}\text { Semi-sweet } \\
\text { wine }\end{array}$ & 13,85 & 11,25 & 4,5 & 5,8 & 131 & 19 & 172 & 3,46 & 1,011 & 70,9 & 44,2 \\
\hline
\end{tabular}

Table B3. Samples from Regional District (Prefecture) of Kavala

\begin{tabular}{|c|c|c|c|c|c|c|c|c|c|c|c|c|c|c|c|c|c|c|}
\hline $\begin{array}{l}\text { Year of } \\
\text { analysis }\end{array}$ & WINERY & WINE & $\begin{array}{c}\text { Wine } \\
\text { Category }\end{array}$ & $\begin{array}{c}\text { Wine } \\
\text { container } \\
\text { (except } \\
\text { bottles) }\end{array}$ & $\begin{array}{l}\text { Year of } \\
\text { Harvest }\end{array}$ & Colour & $\begin{array}{c}\text { Type of } \\
\text { Wine }\end{array}$ & $\begin{array}{c}\text { Total } \\
\text { Alcoholic } \\
\text { Strength } \\
\text { (\% Vol. } \\
200 \text { C) }\end{array}$ & $\begin{array}{c}\text { Obtained } \\
\text { Alcoholic } \\
\text { Strength } \\
\text { (\% Vol. } \\
200 \text { C) }\end{array}$ & $\begin{array}{c}\text { Total } \\
\text { Acidity } \\
\text { (g/l } \\
\text { tartaric } \\
\text { acid) }\end{array}$ & $\begin{array}{l}\text { Volatile } \\
\text { Acidity } \\
\text { (meq/l) }\end{array}$ & $\begin{array}{c}\text { Total } \\
\text { Sulphur } \\
(\mathrm{mg} / \mathrm{l})\end{array}$ & $\begin{array}{c}\text { Free } \\
\text { Sulphur } \\
(\mathrm{mg} / \mathrm{l})\end{array}$ & $\begin{array}{l}\text { Sorbic } \\
\text { Acid } \\
(\mathrm{mg} / \mathrm{l})\end{array}$ & pH & $\begin{array}{c}\text { Density of } \\
\text { Wine } \\
(\mathrm{g} / \mathrm{ml})\end{array}$ & \begin{tabular}{|c|} 
Total \\
Wine Solid \\
Residues \\
or Total \\
Dry \\
Extract of \\
Wine $(\mathrm{g} / \mathrm{l})$ \\
\end{tabular} & $\begin{array}{c}\text { Residual } \\
\text { Sugars } \\
\text { (g/l) }\end{array}$ \\
\hline 2008 & \begin{tabular}{|c|} 
WINERY \\
25
\end{tabular} & W25.3 & $\begin{array}{l}\text { Paggaio - } \\
\text { LW }\end{array}$ & & 2006 & RED & Dry wine & 12,45 & 12,28 & 4,2 & 10,7 & 61 & & & 3,75 & & & 2,8 \\
\hline 2008 & $\begin{array}{c}\text { WINERY } \\
58\end{array}$ & W58.1 & Table Wine & & 2008 & RED & Dry wine & 12,55 & 12,4 & 4,3 & 13,2 & 46 & & & 3,78 & & & 2,6 \\
\hline 2008 & $\begin{array}{c}\text { WINERY } \\
58\end{array}$ & W58.2 & Table Wine & & 2008 & WHITE & Dry wine & 12,43 & 12,35 & 3,8 & 7,6 & 72 & & & 3,51 & & & 1,4 \\
\hline 2008 & $\begin{array}{c}\text { WINERY } \\
58\end{array}$ & W58.3 & $\begin{array}{c}\text { Paggaio - } \\
\text { LW }\end{array}$ & & 2007 & WHITE & Dry wine & 13,32 & 13,21 & 5 & 5,2 & 93 & & & 3,42 & & & 1,8 \\
\hline 2008 & $\begin{array}{c}\text { WINERY } \\
58\end{array}$ & W58.4 & $\begin{array}{l}\text { Paggaio - } \\
\text { LW }\end{array}$ & & 2007 & ROSE & $\begin{array}{c}\text { Semi-sweet } \\
\text { wine }\end{array}$ & 13,09 & 12,38 & 4 & 5,5 & 102 & & & 3,65 & & & 11,9 \\
\hline 2008 & \begin{tabular}{|c|} 
WINERY \\
58
\end{tabular} & W58.5 & $\begin{array}{c}\text { Paggaio - } \\
\text { LW }\end{array}$ & & 2006 & RED & Dry wine & 13,34 & 13,2 & 4,6 & 9,3 & 60 & & & 3,73 & & & 2,3 \\
\hline 2008 & \begin{tabular}{|c|} 
WINERY \\
58
\end{tabular} & W58.6 & $\begin{array}{c}\text { Paggaio - } \\
\text { LW }\end{array}$ & & 2005 & RED & Dry wine & 13,16 & 13,04 & 4,6 & 7,6 & 54 & & & 3,61 & & & 2 \\
\hline 2008 & $\begin{array}{c}\text { WINERY } \\
70\end{array}$ & W70.1 & Table Wine & Wine tanks & 2007 & RED & Dry wine & 11,92 & 11,8 & 4,1 & 10,3 & 32 & 13 & & 3,74 & & & 2 \\
\hline 2008 & $\begin{array}{c}\text { WINERY } \\
70\end{array}$ & W70.1 & Table Wine & Wine tanks & 2007 & RED & Dry wine & 12,03 & 11,91 & 4,2 & 10,5 & 40 & 13 & & 3,71 & & & 2 \\
\hline 2008 & $\begin{array}{c}\text { WINERY } \\
70\end{array}$ & W70.2 & Table Wine & Wine tanks & 2007 & RED & Dry wine & 12,83 & 12,65 & 4,1 & 6,1 & 61 & 24 & & 3,8 & & & 3 \\
\hline
\end{tabular}




\begin{tabular}{|c|c|c|c|c|c|c|c|c|c|c|c|c|c|c|c|c|c|c|}
\hline 2008 & \begin{tabular}{|c|} 
WINERY \\
1
\end{tabular} & W1.1 & \begin{tabular}{c|} 
Paggaio - \\
LW
\end{tabular} & $\begin{array}{l}\text { Wooden } \\
\text { barrels }\end{array}$ & 2005 & RED & Dry wine & 13,51 & 13,35 & 6,1 & 5,6 & 63 & 32 & & 3,49 & & & 2,7 \\
\hline 2015 & $\begin{array}{c}\text { WINERY } \\
72\end{array}$ & W72.1 & $\begin{array}{c}\text { PGI } \\
\text { Paggaio }\end{array}$ & & 2014 & WHITE & Dry wine & 13,25 & 13,1 & 5,1 & 3,7 & 131 & 28 & & 3,21 & 0,987 & 19,6 & 2,5 \\
\hline 2015 & $\begin{array}{c}\text { WINERY } \\
72\end{array}$ & W72.2 & $\begin{array}{c}\text { PGI } \\
\text { Paggaio }\end{array}$ & & 2008 & RED & Dry wine & 14,43 & 14,23 & 4,7 & 9,6 & 125 & 23 & & 3,67 & 0,992 & 31 & 3,4 \\
\hline 2015 & $\begin{array}{c}\text { WINERY } \\
65\end{array}$ & W65.1 & $\begin{array}{c}\text { PGI } \\
\text { Paggaio }\end{array}$ & & 2014 & WHITE & Dry wine & 12,75 & 12,64 & 5,1 & 5,3 & 200 & 66 & & 3,53 & 0,99 & 20,6 & 1,9 \\
\hline 2015 & $\begin{array}{c}\text { WINERY } \\
65\end{array}$ & W65.2 & $\begin{array}{c}\text { PGI } \\
\text { Paggaio }\end{array}$ & & 2011 & RED & Dry wine & 14,2 & 13,9 & 4,9 & 11,6 & 130 & 23 & & 3,74 & 0,992 & 29,4 & 5,1 \\
\hline 2016 & $\begin{array}{c}\text { WINERY } \\
23\end{array}$ & W23.1 & $\begin{array}{c}\text { PGI } \\
\text { Paggaio }\end{array}$ & & 2015 & WHITE & Dry wine & 12,8 & 12,73 & 4,9 & 8,3 & 107 & 35 & & 3,42 & 0,989 & 17,5 & 1,2 \\
\hline 2016 & \begin{tabular}{|c|} 
WINERY \\
23
\end{tabular} & W23.2 & $\begin{array}{c}\text { PGI } \\
\text { Paggaio }\end{array}$ & & 2015 & ROSE & Dry wine & 12,84 & 12,75 & 4,3 & 5,6 & 135 & 40 & & 3,71 & 0,99 & 21,6 & 1,6 \\
\hline 2016 & \begin{tabular}{|c|} 
WINERY \\
23
\end{tabular} & W23.3 & $\begin{array}{c}\text { PGI } \\
\text { Paggaio }\end{array}$ & & 2015 & RED & Dry wine & 13,01 & 12,87 & 4,7 & 17,3 & 102 & 17 & & 3,93 & 0,992 & 27,9 & 2,3 \\
\hline 2016 & $\begin{array}{c}\text { WINERY } \\
11\end{array}$ & W11.1 & PGI Kavala & & 2012 & RED & Dry wine & 13,41 & 13,23 & 6,2 & 10,7 & 127 & 31 & & 3,8 & 0,993 & 30,5 & 3,1 \\
\hline 2016 & $\begin{array}{c}\text { WINERY } \\
11\end{array}$ & W11.2 & & & 2015 & WHITE & Dry wine & 13,36 & 13,26 & 5,4 & 4,8 & 90 & 36 & & 3,06 & 0,988 & 18,3 & 1,7 \\
\hline 2016 & $\begin{array}{c}\text { WINERY } \\
10\end{array}$ & W10.1 & $\begin{array}{c}\text { PGI } \\
\text { Paggaio }\end{array}$ & & 2015 & WHITE & Dry wine & 13,02 & 12,91 & 5,7 & 4,2 & 95 & 13 & & 3,17 & 0,99 & 21,1 & 1,8 \\
\hline 2016 & $\begin{array}{c}\text { WINERY } \\
10\end{array}$ & W10.2 & $\begin{array}{c}\text { PGI } \\
\text { Paggaio }\end{array}$ & & 2015 & ROSE & Dry wine & 13,46 & 13,2 & 6,1 & 7,4 & 74 & 12 & & 3,04 & 0,99 & 22,9 & 4,3 \\
\hline 2016 & $\begin{array}{c}\text { WINERY } \\
56\end{array}$ & W56.1 & $\begin{array}{c}\text { PGI } \\
\text { Paggaio }\end{array}$ & & 2015 & WHITE & Dry wine & 12,41 & 12,3 & 4,8 & 5 & 111 & 21 & & 3,2 & 0,989 & 18,5 & 1,9 \\
\hline 2016 & $\begin{array}{c}\text { WINERY } \\
56\end{array}$ & W56.2 & $\begin{array}{c}\text { PGI } \\
\text { Paggaio }\end{array}$ & & 2015 & ROSE & Dry wine & 12,81 & 12,33 & 4,4 & 4,3 & 143 & 21 & & 3,31 & 0,992 & 25,3 & 8,1 \\
\hline 2016 & \begin{tabular}{|c|} 
WINERY \\
56
\end{tabular} & W56.3 & $\begin{array}{c}\text { PGI } \\
\text { Paggaio }\end{array}$ & & 2015 & RED & Dry wine & 13,1 & 12,98 & 4,3 & 5,9 & 95 & 27 & & 3,68 & 0,991 & 24,2 & 2,1 \\
\hline 2016 & $\begin{array}{c}\text { WINERY } \\
18\end{array}$ & W18.1 & $\begin{array}{c}\text { PGI } \\
\text { Paggaio }\end{array}$ & & 2015 & WHITE & Dry wine & 12,51 & 12,43 & 3,8 & 3,6 & 102 & 37 & & 3,69 & 0,989 & 19,3 & 1,4 \\
\hline 2016 & $\begin{array}{c}\text { WINERY } \\
18\end{array}$ & W18.2 & $\begin{array}{c}\text { PGI } \\
\text { Paggaio }\end{array}$ & & 2012 & RED & Dry wine & 13,15 & 12,99 & 4,5 & 8,5 & 118 & 26 & & 3,64 & 0,992 & 26,6 & 2,7 \\
\hline 2016 & $\begin{array}{c}\text { WINERY } \\
52\end{array}$ & W52.1 & & Wine tanks & 2015 & RED & Dry wine & 10,73 & 10,31 & 13,4 & 140,3 & 22 & 6 & & 3,64 & 0,996 & 26,1 & 7,1 \\
\hline 2017 & $\begin{array}{c}\text { WINERY } \\
11\end{array}$ & W11.3 & PGI Kavala & & 2017 & WHITE & Dry wine & 13,83 & 13,71 & 5,4 & 4,9 & 113 & 33 & 3 & 3,22 & 0,998 & 20,6 & 2 \\
\hline 2017 & $\begin{array}{c}\text { WINERY } \\
57\end{array}$ & W57.1 & $\begin{array}{c}\text { PGI } \\
\text { Paggaio }\end{array}$ & & 2017 & RED & Dry wine & 13,53 & 13,39 & 4,8 & 5,4 & 79 & 18 & 3 & 3,57 & 0,99 & 25,3 & 2,4 \\
\hline 2017 & \begin{tabular}{|c|} 
WINERY \\
57
\end{tabular} & W57.2 & $\begin{array}{c}\text { PGI } \\
\text { Paggaio }\end{array}$ & & 2017 & WHITE & Dry wine & 13,31 & 13,14 & 5,2 & 4,8 & 111 & 21 & 5 & 3,08 & 0,998 & 19 & 2,9 \\
\hline 2017 & $\begin{array}{c}\text { WINERY } \\
10\end{array}$ & W10.3 & $\begin{array}{c}\text { PGI } \\
\text { Paggaio }\end{array}$ & & 2016 & WHITE & Dry wine & 13,26 & 13,14 & 5,3 & 3,6 & 95 & 22 & 12 & 3,2 & 0,989 & 20,1 & 2 \\
\hline 2018 & $\begin{array}{c}\text { WINERY } \\
41\end{array}$ & W41.1 & PGI Thasos & & 2016 & RED & Dry wine & 13,47 & 13,28 & 5,67 & 9,2 & 55 & 8 & 0 & 3,52 & 0,992 & 29,4 & 3,2 \\
\hline 2018 & $\begin{array}{c}\text { WINERY } \\
72\end{array}$ & W72.3 & $\begin{array}{c}\text { PGI } \\
\text { Paggaio }\end{array}$ & & 2012 & RED & Dry wine & 14,42 & 14,24 & 4,8 & 9,7 & 110 & 14 & 0 & 3,71 & 0,992 & 32,6 & 3 \\
\hline 2018 & $\begin{array}{c}\text { WINERY } \\
4\end{array}$ & W4.1 & $\begin{array}{c}\text { PGI } \\
\text { Paggaio }\end{array}$ & & 2017 & WHITE & Dry wine & 14,11 & 13,91 & 7,1 & 4,9 & 106 & 16 & 0 & 3,05 & 0,998 & 23,2 & 3,3 \\
\hline 2018 & $\begin{array}{c}\text { WINERY } \\
4 \\
\end{array}$ & W4.2 & $\begin{array}{c}\text { PGI } \\
\text { Paggaio }\end{array}$ & & 2017 & RED & Dry wine & 14,02 & 13,8 & 6,6 & 5,2 & 86 & 9 & 0 & 3,12 & 0,989 & 22,4 & 3,7 \\
\hline
\end{tabular}




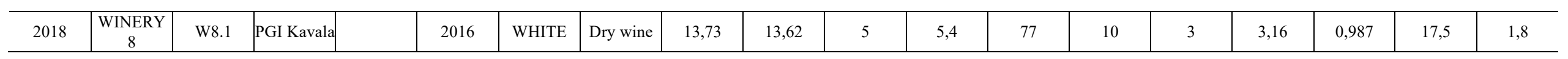

Table B4. Samples from Regional District (Prefecture) of Rodopi

\begin{tabular}{|c|c|c|c|c|c|c|c|c|c|c|c|c|c|c|c|c|c|c|}
\hline $\begin{array}{l}\text { Year of } \\
\text { analysis }\end{array}$ & WINERY & WINE & $\begin{array}{c}\text { Wine } \\
\text { Category }\end{array}$ & $\begin{array}{c}\text { Wine } \\
\text { container } \\
\text { (except } \\
\text { bottles) }\end{array}$ & $\begin{array}{l}\text { Year of } \\
\text { Harvest }\end{array}$ & Colour & $\begin{array}{c}\text { Type of } \\
\text { Wine }\end{array}$ & $\begin{array}{c}\text { Total } \\
\text { Alcoholic } \\
\text { Strength } \\
\text { (\% Vol. } \\
\text { 20o C) }\end{array}$ & $\begin{array}{c}\text { Obtained } \\
\text { Alcoholic } \\
\text { Strength } \\
(\% \text { Vol. } \\
200 \text { C) }\end{array}$ & $\begin{array}{c}\text { Total } \\
\text { Acidity } \\
(\mathrm{g} / \mathrm{l} \\
\text { tartaric } \\
\text { acid) }\end{array}$ & $\begin{array}{l}\text { Volatile } \\
\text { Acidity } \\
\text { (meq/l) }\end{array}$ & $\begin{array}{l}\text { Total } \\
\text { Sulphur } \\
(\mathrm{mg} / \mathrm{l})\end{array}$ & $\begin{array}{c}\text { Free } \\
\text { Sulphur } \\
(\mathrm{mg} / \mathrm{l})\end{array}$ & $\begin{array}{l}\text { Sorbic } \\
\text { Acid } \\
(\mathbf{m g} / \mathrm{l})\end{array}$ & pH & $\begin{array}{c}\text { Density of } \\
\text { Wine } \\
(\mathrm{g} / \mathrm{ml})\end{array}$ & \begin{tabular}{|c|} 
Total \\
Wine Solid \\
Residues \\
or Total \\
Dry \\
Extract of \\
Wine $(\mathrm{g} / \mathrm{l})$ \\
\end{tabular} & $\begin{array}{l}\text { Residual } \\
\text { Sugars } \\
\text { (g/l) }\end{array}$ \\
\hline 2014 & $\begin{array}{c}\text { WINERY } \\
35\end{array}$ & W35.1 & $\begin{array}{c}\text { Ismaros - } \\
\text { LW }\end{array}$ & & 2008 & RED & Dry wine & 14,28 & 14,07 & 4,7 & 9,5 & 74 & 10 & & 3,54 & 0,991 & 27,6 & 3,5 \\
\hline 2014 & $\begin{array}{c}\text { WINERY } \\
35\end{array}$ & W35.2 & $\begin{array}{l}\text { PGI } \\
\text { Ismaros }\end{array}$ & & 2013 & WHITE & Dry wine & 13,83 & 13,72 & 5 & 9,7 & 156 & 35 & & 3,32 & 0,988 & 18,5 & 1,9 \\
\hline 2014 & $\begin{array}{c}\text { WINERY } \\
35\end{array}$ & W35.3 & $\begin{array}{l}\text { PGI } \\
\text { Ismaros }\end{array}$ & & 2009 & RED & Dry wine & 14,77 & 14,48 & 5,7 & 13,1 & 119 & 20 & & 3,48 & 0,992 & 31,3 & 4,8 \\
\hline 2016 & $\begin{array}{c}\text { WINERY } \\
35\end{array}$ & W35.1 & $\begin{array}{l}\text { PGI } \\
\text { Ismaros }\end{array}$ & & 2013 & RED & Dry wine & 12,57 & 12,42 & 5,8 & 19 & 250 & 16 & & 3,48 & 0,993 & 28,4 & 2,5 \\
\hline 2016 & $\begin{array}{c}\text { WINERY } \\
35\end{array}$ & W35.2 & $\begin{array}{l}\text { PGI } \\
\text { Ismaros }\end{array}$ & & 2014 & WHITE & Dry wine & 14,34 & 14,25 & 5,5 & 8,6 & 118 & 22 & & 3,28 & 0,988 & 20,6 & 1,5 \\
\hline 2016 & $\begin{array}{c}\text { WINERY } \\
35\end{array}$ & W35.5 & $\begin{array}{l}\text { PGI } \\
\text { Ismaros }\end{array}$ & & 2015 & ROSE & Dry wine & 14,73 & 14,61 & 5,9 & 11,5 & 172 & 21 & & 3,09 & 0,988 & 20,6 & 2,1 \\
\hline 2016 & $\begin{array}{c}\text { WINERY } \\
75\end{array}$ & W75.1 & $\begin{array}{l}\text { Varietal } \\
\text { wine }\end{array}$ & & 2013 & WHITE & Dry wine & 14,67 & 14,41 & 4,7 & 7,5 & 70 & 7 & & 3,39 & 0,988 & 20,9 & 4,3 \\
\hline 2016 & $\begin{array}{c}\text { WINERY } \\
12\end{array}$ & W12.1 & & & 2013 & RED & Dry wine & 13,07 & 12,86 & 5,3 & 19,5 & 62 & 17 & & 3,83 & 0,995 & 33,9 & 3,6 \\
\hline 2016 & $\begin{array}{c}\text { WINERY } \\
63\end{array}$ & W63.1 & & Wine tanks & 2015 & RED & Dry wine & 13,43 & 13,31 & 4,4 & 10,5 & 62 & 17 & & 3,78 & 0,991 & 26,8 & 2,1 \\
\hline 2018 & $\begin{array}{c}\text { WINERY } \\
19\end{array}$ & W19.1 & $\begin{array}{c}\text { Traditional } \\
\text { Appellation, } \\
\text { Retsina }\end{array}$ & & 2018 & WHITE & Dry wine & 11,78 & 11,68 & 4,04 & 4,5 & 108 & 13 & 0 & 3,41 & 0,99 & 17,5 & 1,6 \\
\hline 2018 & $\begin{array}{c}\text { WINERY } \\
19\end{array}$ & W19.2 & & & 2018 & WHITE & Dry wine & 11,78 & 11,67 & 4,18 & 3,6 & 126 & 36 & 0 & 3,38 & 0,99 & 18 & 1,8 \\
\hline
\end{tabular}




\begin{tabular}{|c|c|c|c|c|c|c|c|c|c|c|c|c|c|c|c|c|c|c|}
\hline 2018 & $\begin{array}{c}\text { WINERY } \\
19\end{array}$ & W19.3 & & & 2018 & WHITE & Sweet wine & 14,17 & 10,89 & 3,79 & 5,2 & 162 & 51 & 177 & 3,43 & 1,012 & 74,6 & 55,2 \\
\hline 2018 & $\begin{array}{c}\text { WINERY } \\
19\end{array}$ & W19.4 & & & 2018 & ROSE & $\begin{array}{c}\text { Semi-sweet } \\
\text { wine }\end{array}$ & 12,93 & 11,25 & 3,89 & 6,4 & 159 & 38 & 166 & 3,63 & 1,002 & 49,1 & 28,3 \\
\hline 2018 & $\begin{array}{c}\text { WINERY } \\
19\end{array}$ & W19.5 & & & 2018 & RED & Sweet wine & 13,97 & 11,4 & 6,36 & 13,8 & 133 & 11 & 165 & 3,74 & 1,015 & 83,2 & 43,2 \\
\hline 2018 & $\begin{array}{c}\text { WINERY } \\
19\end{array}$ & W19.6 & & & 2018 & RED & Dry wine & 13,29 & 13,12 & 4,17 & 8,7 & 94 & 16 & 7 & 3,84 & 0,992 & 29,2 & 2,9 \\
\hline 2018 & \begin{tabular}{|c} 
WINERY \\
19
\end{tabular} & W19.7 & & & 2018 & RED & Dry wine & 12,89 & 12,78 & 4,33 & 15,9 & 76 & 19 & 5 & 3,91 & 0,991 & 24,5 & 1,9 \\
\hline 2018 & $\begin{array}{c}\text { WINERY } \\
35\end{array}$ & W35.4 & $\begin{array}{c}\text { PGI } \\
\text { Ismaros }\end{array}$ & & 2018 & WHITE & Dry wine & 14,17 & 13,99 & 5,51 & 9,5 & 147 & 22 & 3 & 3,27 & 0,989 & 21,6 & 3,1 \\
\hline 2018 & $\begin{array}{c}\text { WINERY } \\
35\end{array}$ & W35.3 & $\begin{array}{c}\text { PGI } \\
\text { Ismaros }\end{array}$ & Wine tanks & 2016 & RED & Dry wine & 14,44 & 14,24 & 4,9 & 13,8 & 142 & 16 & 6 & 3,72 & 0,992 & 31,5 & 3,4 \\
\hline 2018 & $\begin{array}{c}\text { WINERY } \\
35\end{array}$ & W35.1 & $\begin{array}{c}\text { Ismaros - } \\
\text { LW }\end{array}$ & Wine tanks & 2016 & RED & Dry wine & 14,28 & 14,08 & 5,3 & 13,7 & 145 & 15 & 3 & 3,59 & 0,992 & 30 & 3,4 \\
\hline 2018 & $\begin{array}{c}\text { WINERY } \\
35\end{array}$ & W35.3 & $\begin{array}{c}\text { PGI } \\
\text { Ismaros }\end{array}$ & Wine tanks & 2016 & RED & Dry wine & 14,68 & 14,48 & 5,6 & 14,5 & 112 & 24 & 2 & 3,57 & 0,992 & 31,5 & 3,4 \\
\hline 2018 & $\begin{array}{c}\text { WINERY } \\
35\end{array}$ & W35.1 & $\begin{array}{l}\text { Ismaros - } \\
\text { LW }\end{array}$ & Wine tanks & 2016 & RED & Dry wine & 14,22 & 14,04 & 5,1 & 13,9 & 176 & 20 & 3 & 3,61 & 0,992 & 29,7 & 3 \\
\hline 2018 & $\begin{array}{c}\text { WINERY } \\
35\end{array}$ & W35.3 & $\begin{array}{c}\text { Ismaros - } \\
\text { LW }\end{array}$ & Wine tanks & 2016 & RED & Dry wine & 14,39 & 14,2 & 4,9 & 14,1 & 177 & 22 & 1 & 3,73 & 0,992 & 31 & 3,2 \\
\hline 2019 & \begin{tabular}{|c} 
WINERY \\
12
\end{tabular} & W12.2 & & Wine tanks & 2018 & WHITE & Dry wine & 14,12 & 13,88 & 5,85 & 8,2 & 65 & 8 & 6 & 3,4 & 0,989 & 24 & 4,1 \\
\hline
\end{tabular}

Table B5. Samples from Regional District (Prefecture) of Serres

\begin{tabular}{|c|c|c|c|c|c|c|c|c|c|c|c|c|c|c|c|c|c|c|}
\hline $\begin{array}{l}\text { Year of } \\
\text { analysis }\end{array}$ & WINERY & WINE & $\begin{array}{c}\text { Wine } \\
\text { Category }\end{array}$ & $\begin{array}{c}\text { Wine } \\
\text { container } \\
\text { (except } \\
\text { bottles) }\end{array}$ & $\begin{array}{c}\text { Year of } \\
\text { Harvest }\end{array}$ & Colour & $\begin{array}{l}\text { Type of } \\
\text { Wine }\end{array}$ & $\begin{array}{c}\text { Total } \\
\text { Alcoholic } \\
\text { Strength } \\
\text { (\% Vol. } \\
200 \text { C) }\end{array}$ & $\begin{array}{c}\text { Obtained } \\
\text { Alcoholic } \\
\text { Strength } \\
\text { (\% Vol. } \\
200 \text { C) }\end{array}$ & $\begin{array}{c}\text { Total } \\
\text { Acidity } \\
\text { (g/l } \\
\text { tartaric } \\
\text { acid) }\end{array}$ & $\begin{array}{l}\text { Volatile } \\
\text { Acidity } \\
\text { (meq/l) }\end{array}$ & $\begin{array}{c}\text { Total } \\
\text { Sulphur } \\
(\mathrm{mg} / \mathrm{l})\end{array}$ & $\begin{array}{c}\text { Free } \\
\text { Sulphur } \\
(\mathrm{mg} / \mathrm{l})\end{array}$ & $\begin{array}{c}\text { Sorbic } \\
\text { Acid } \\
(\mathbf{m g} / \mathbf{l})\end{array}$ & $\mathbf{p H}$ & $\begin{array}{c}\text { Density of } \\
\text { Wine } \\
\text { (g/ml) }\end{array}$ & \begin{tabular}{|c|} 
Total \\
Wine Solid \\
Residues \\
or Total \\
Dry \\
Extract of \\
Wine $(\mathrm{g} / \mathrm{l})$
\end{tabular} & $\begin{array}{c}\text { Residual } \\
\text { Sugars } \\
(\mathrm{g} / \mathrm{l})\end{array}$ \\
\hline
\end{tabular}




\begin{tabular}{|c|c|c|c|c|c|c|c|c|c|c|c|c|c|c|c|}
\hline 2010 & \begin{tabular}{|c|} 
WINERY \\
69
\end{tabular} & W69.1 & Table Wine & & 2010 & WHITE & Dry wine & 11,83 & 11,76 & 5,7 & 8,3 & 137 & 6 & 3,36 & 1,2 \\
\hline 2010 & $\begin{array}{c}\text { WINERY } \\
42\end{array}$ & W42.1 & Serres - LW & Wine tanks & 2010 & WHITE & $\begin{array}{l}\text { Semi-dry } \\
\text { wine }\end{array}$ & 13,66 & 13,2 & 4,6 & 8,3 & 116 & 17 & 3,62 & 7,8 \\
\hline 2010 & $\begin{array}{c}\text { WINERY } \\
42\end{array}$ & W42.2 & Serres - LW & Wine tanks & 2008 & RED & Dry wine & 14,03 & 13,88 & 4,5 & 7,8 & 92 & 32 & 3,71 & 2,6 \\
\hline 2010 & $\begin{array}{c}\text { WINERY } \\
73\end{array}$ & W73.1 & Serres - LW & & 2008 & RED & Dry wine & 14,55 & 14,4 & 5 & 9,1 & 78 & 45 & 3,81 & 2,5 \\
\hline 2010 & $\begin{array}{c}\text { WINERY } \\
64\end{array}$ & W64.1 & Serres - LW & & 2009 & WHITE & Dry wine & 13,85 & 13,71 & 5,6 & 10,3 & 129 & 33 & 3,52 & 2,4 \\
\hline 2010 & $\begin{array}{c}\text { WINERY } \\
16\end{array}$ & W16.1 & Table Wine & & 2009 & WHITE & Dry wine & 12,42 & 12,24 & 5,5 & 5,8 & 152 & 14 & 3,33 & 3 \\
\hline 2010 & $\begin{array}{c}\text { WINERY } \\
16\end{array}$ & W16.2 & Table Wine & & 2009 & RED & Dry wine & 12,81 & 12,64 & 4,5 & 7,9 & 88 & 30 & 3,72 & 2,9 \\
\hline 2010 & $\begin{array}{c}\text { WINERY } \\
34\end{array}$ & W34.1 & Table Wine & & 2009 & WHITE & Dry wine & 13,25 & 13,11 & 5,2 & 5,6 & 98 & 15 & 3,44 & 2,4 \\
\hline 2010 & \begin{tabular}{|c|} 
WINERY \\
34
\end{tabular} & W34.2 & Table Wine & & 2009 & RED & Dry wine & 13,73 & 13,63 & 6,8 & 5,2 & 84 & 27 & 3,47 & 1,7 \\
\hline 2010 & $\begin{array}{c}\text { WINERY } \\
34\end{array}$ & W34.3 & Table Wine & & 2009 & RED & Dry wine & 13,21 & 13,1 & 5,8 & 4,8 & 82 & 24 & 3,47 & 1,9 \\
\hline 2010 & $\begin{array}{c}\text { WINERY } \\
44\end{array}$ & W44.1 & Table Wine & & 2009 & WHITE & Dry wine & 13,8 & 13,69 & 4,8 & 5,6 & 79 & 12 & 3,61 & 1,9 \\
\hline 2010 & $\begin{array}{c}\text { WINERY } \\
44\end{array}$ & W44.2 & Table Wine & & 2009 & ROSE & $\begin{array}{l}\text { Semi-dry } \\
\text { wine }\end{array}$ & 13,77 & 13,51 & 4,7 & 11,3 & 164 & 56 & 3,39 & 4,4 \\
\hline 2010 & $\begin{array}{c}\text { WINERY } \\
44\end{array}$ & W44.3 & $\begin{array}{c}\text { Macedonia } \\
\text { - LW }\end{array}$ & & 2008 & RED & Dry wine & 13,95 & 13,79 & 5,6 & 6,9 & 64 & 22 & 3,25 & 2,7 \\
\hline 2010 & $\begin{array}{c}\text { WINERY } \\
49\end{array}$ & W49.1 & Table Wine & & 2009 & WHITE & Dry wine & 13,66 & 13,55 & 4,7 & 6,4 & 152 & 52 & 3,28 & 1,8 \\
\hline 2010 & $\begin{array}{c}\text { WINERY } \\
49\end{array}$ & W49.2 & Serres - LW & & 2009 & ROSE & Dry wine & 12,93 & 12,77 & 5,7 & 5,3 & 115 & 33 & 3,42 & 2,7 \\
\hline 2010 & $\begin{array}{c}\text { WINERY } \\
49\end{array}$ & W49.3 & Serres - LW & & 2008 & RED & Dry wine & 13,65 & 13,44 & 5,3 & 6,4 & 96 & 32 & 3,61 & 3,5 \\
\hline 2010 & $\begin{array}{c}\text { WINERY } \\
21\end{array}$ & W21.1 & Table Wine & & 2009 & WHITE & Dry wine & 12,05 & 11,95 & 5,5 & 3,6 & 91 & 22 & 3,36 & 1,7 \\
\hline 2010 & $\begin{array}{c}\text { WINERY } \\
21\end{array}$ & W21.2 & Serres - LW & & 2009 & WHITE & Dry wine & 12,63 & 12,53 & 5,1 & 3,6 & 120 & 40 & 3,51 & 1,7 \\
\hline 2010 & $\begin{array}{c}\text { WINERY } \\
21\end{array}$ & W21.3 & Serres - LW & & 2009 & RED & Dry wine & 12,4 & 12,23 & 5,7 & 5 & 90 & 29 & 3,52 & 2,8 \\
\hline 2010 & $\begin{array}{c}\text { WINERY } \\
32\end{array}$ & W32.1 & Table Wine & & 2009 & WHITE & Dry wine & 11,87 & 11,76 & 5,9 & 6,9 & 56 & 8 & 3,29 & 1,9 \\
\hline 2010 & $\begin{array}{c}\text { WINERY } \\
32\end{array}$ & W32.2 & Serres - LW & & 2008 & RED & Dry wine & 12,67 & 12,5 & 6,3 & 9,4 & 48 & 14 & 3,39 & 2,8 \\
\hline 2010 & $\begin{array}{c}\text { WINERY } \\
46\end{array}$ & W46.1 & Serres - LW & & 2008 & WHITE & Dry wine & 13,73 & 13,59 & 5,1 & 6,1 & 100 & 39 & 3,5 & 2,3 \\
\hline 2010 & $\begin{array}{c}\text { WINERY } \\
46\end{array}$ & W46.2 & Serres - LW & & 2008 & ROSE & Dry wine & 14,22 & 14,1 & 5,4 & 6,9 & 79 & 17 & 3,3 & 2 \\
\hline 2010 & $\begin{array}{c}\text { WINERY } \\
46\end{array}$ & W46.3 & Serres - LW & & 2007 & RED & Dry wine & 12,69 & 12,48 & 6,1 & 7,1 & 92 & 18 & 3,4 & 3,5 \\
\hline 2010 & $\begin{array}{c}\text { WINERY } \\
46\end{array}$ & W46.3 & Serres - LW & & 2007 & RED & Dry wine & 13,56 & 13,37 & 6 & 7,4 & 88 & 18 & 3,4 & 3,2 \\
\hline 2010 & $\begin{array}{c}\text { WINERY } \\
46\end{array}$ & W46.4 & Serres - LW & & 2007 & RED & Dry wine & 13,88 & 13,7 & 6,5 & 9 & 78 & 19 & 3,44 & 3,1 \\
\hline
\end{tabular}




\begin{tabular}{|c|c|c|c|c|c|c|c|c|c|c|c|c|c|c|}
\hline 2010 & \begin{tabular}{|c} 
WINERY \\
2
\end{tabular} & W2.1 & $\begin{array}{c}\text { Macedonia } \\
\text { - LW }\end{array}$ & 2009 & WHITE & Dry wine & 13,77 & 13,7 & 4,9 & 9,9 & 70 & 5 & 3,47 & 1,1 \\
\hline 2010 & $\begin{array}{c}\text { WINERY } \\
2\end{array}$ & W2.3 & Serres - LW & 2008 & ROSE & Dry wine & 15,35 & 15,25 & 5,4 & 6,9 & 23 & 6 & 3,58 & 1,6 \\
\hline 2010 & $\begin{array}{c}\text { WINERY } \\
2\end{array}$ & W2.4 & Serres - LW & 2007 & RED & Dry wine & 14,02 & 13,8 & 5,5 & 13,3 & 86 & 24 & 3,56 & 3,7 \\
\hline 2010 & $\begin{array}{c}\text { WINERY } \\
50\end{array}$ & W50.1 & Serres - LW & 2006 & RED & Dry wine & 13,26 & 13,16 & 5,3 & 8,7 & 84 & 21 & 3,5 & 1,7 \\
\hline 2010 & $\begin{array}{c}\text { WINERY } \\
50\end{array}$ & W50.2 & Serres - LW & 2007 & RED & Dry wine & 12,77 & 12,67 & 4,7 & 11 & 116 & 24 & 3,64 & 1,6 \\
\hline 2010 & $\begin{array}{c}\text { WINERY } \\
50\end{array}$ & W50.3 & Serres - LW & 2009 & WHITE & Dry wine & 12,71 & 12,61 & 5,2 & 5,8 & 90 & 12 & 3,57 & 1,6 \\
\hline 2010 & $\begin{array}{c}\text { WINERY } \\
40\end{array}$ & W40.1 & Serres - LW & 2009 & WHITE & Dry wine & 11,78 & 11,55 & 3,7 & 11,1 & 77 & & 3,69 & 3,9 \\
\hline 2010 & $\begin{array}{c}\text { WINERY } \\
40\end{array}$ & W40.2 & Serres - LW & 2009 & WHITE & Dry wine & 12,28 & 12,19 & 4,7 & 6,6 & 102 & & 3,54 & 1,5 \\
\hline 2011 & $\begin{array}{c}\text { WINERY } \\
46\end{array}$ & W46.4 & Serres - LW & 2009 & RED & Dry wine & 14,29 & 14,19 & 6,06 & 8,2 & 62 & 16 & 3,54 & 1,7 \\
\hline 2011 & $\begin{array}{c}\text { WINERY } \\
46\end{array}$ & W46.3 & Serres - LW & 2009 & RED & Dry wine & 14,3 & 14,19 & 6,2 & 9 & 106 & 16 & 3,49 & 1,9 \\
\hline 2011 & $\begin{array}{c}\text { WINERY } \\
50\end{array}$ & W50.4 & Serres - LW & 2009 & RED & Dry wine & 13,14 & 13,05 & 4,1 & 10,9 & 100 & 22 & 3,99 & 1,46 \\
\hline 2011 & $\begin{array}{c}\text { WINERY } \\
50\end{array}$ & W50.5 & & 2009 & RED & Dry wine & 12,71 & 12,61 & 4,1 & 11,1 & 90 & 19 & 4,03 & 1,7 \\
\hline 2011 & $\begin{array}{c}\text { WINERY } \\
64\end{array}$ & W64.2 & Serres - LW & 2009 & RED & Dry wine & 14,19 & 14,08 & 5,1 & 10,7 & 102 & 29 & 3,52 & 1,9 \\
\hline 2011 & $\begin{array}{c}\text { WINERY } \\
46\end{array}$ & W46.5 & Serres - LW & 2009 & WHITE & Dry wine & 13,69 & 13,58 & 5,2 & 6,7 & 110 & 40 & 3,4 & 1,8 \\
\hline 2011 & $\begin{array}{c}\text { WINERY } \\
46\end{array}$ & W44.9 & Serres - LW & 2009 & ROSE & Dry wine & 13,91 & 13,75 & 5,1 & 9,7 & 116 & 58 & 3,33 & 2,7 \\
\hline 2011 & $\begin{array}{c}\text { WINERY } \\
46\end{array}$ & W44.10 & Serres - LW & 2009 & WHITE & Dry wine & 12,7 & 12,56 & 4,9 & 6,9 & 129 & 46 & 3,43 & 2,3 \\
\hline 2011 & $\begin{array}{c}\text { WINERY } \\
46\end{array}$ & W44.11 & Serres - LW & 2009 & RED & Dry wine & 14,17 & 14 & 5,8 & 9,7 & 94 & 18 & 3,41 & 2,8 \\
\hline 2011 & $\begin{array}{c}\text { WINERY } \\
50\end{array}$ & W50.6 & Serres - LW & 2010 & WHITE & Dry wine & 12,61 & 12,5 & 5,2 & 6,4 & 82 & 10 & 3,49 & 1,9 \\
\hline 2011 & $\begin{array}{c}\text { WINERY } \\
40\end{array}$ & W40.3 & Serres - LW & 2010 & RED & Dry wine & 12,92 & 12,8 & 4,8 & 11,4 & 124 & 26 & 3,63 & 2,1 \\
\hline 2011 & $\begin{array}{c}\text { WINERY } \\
40\end{array}$ & W40.4 & Serres - LW & 2009 & RED & Dry wine & 12,55 & 12,41 & 5 & 12,8 & 78 & 21 & 3,63 & 2,3 \\
\hline 2011 & $\begin{array}{c}\text { WINERY } \\
40\end{array}$ & W40.2 & Serres - LW & 2009 & WHITE & Dry wine & 11,92 & 11,84 & 3,6 & 11,2 & 38 & 9 & 3,72 & 1,4 \\
\hline 2011 & $\begin{array}{c}\text { WINERY } \\
40\end{array}$ & W40.1 & Serres - LW & 2009 & WHITE & Dry wine & 11,55 & 11,46 & 4,5 & 8,8 & 28 & 5 & 3,31 & 1,5 \\
\hline 2011 & $\begin{array}{c}\text { WINERY } \\
73\end{array}$ & W73.1 & Serres - LW & 2009 & RED & Dry wine & 14,14 & 14,02 & 5,2 & 15,9 & 60 & 24 & 3,87 & 2 \\
\hline 2011 & $\begin{array}{c}\text { WINERY } \\
74\end{array}$ & W74.1 & Serres - LW & 2009 & RED & Dry wine & 13,22 & 13,07 & 5,4 & 8,8 & 96 & 27 & 3,9 & 2,5 \\
\hline 2011 & $\begin{array}{c}\text { WINERY } \\
74\end{array}$ & W74.2 & Serres - LW & 2010 & WHITE & Dry wine & 13,27 & 13,16 & 5,4 & 9,4 & 61 & 13 & 3,48 & 1,8 \\
\hline 2011 & $\begin{array}{c}\text { WINERY } \\
74\end{array}$ & W74.3 & Serres - LW & 2010 & WHITE & Dry wine & 13,83 & 13,7 & 4,7 & 10 & 158 & 33 & 3,48 & 2 \\
\hline
\end{tabular}




\begin{tabular}{|c|c|c|c|c|c|c|c|c|c|c|c|c|c|c|}
\hline 2011 & \begin{tabular}{|c} 
WINERY \\
69
\end{tabular} & W69.2 & Serres - LW & 2010 & WHITE & Dry wine & 11,89 & 11,82 & 5,1 & 5,7 & 81 & 14 & 3,57 & 1,2 \\
\hline 2011 & $\begin{array}{c}\text { WINERY } \\
69\end{array}$ & W69.3 & Serres - LW & 2009 & RED & Dry wine & 13,74 & 13,59 & 4,2 & 12 & 86 & 16 & 3,9 & 2,4 \\
\hline 2011 & $\begin{array}{c}\text { WINERY } \\
27\end{array}$ & W27.1 & Serres - LW & 2009 & RED & Dry wine & 13,27 & 13,14 & 4,3 & 11 & 122 & 18 & 3,92 & 2,2 \\
\hline 2011 & $\begin{array}{c}\text { WINERY } \\
32\end{array}$ & W32.3 & Serres - LW & 2009 & WHITE & Dry wine & 13,28 & 13,64 & 3 & 5,2 & 56 & 10 & 4,18 & 1,7 \\
\hline 2011 & $\begin{array}{c}\text { WINERY } \\
44\end{array}$ & W44.4 & Serres - LW & 2009 & WHITE & Dry wine & 13,57 & 13,49 & 5,3 & 6,9 & 119 & 19 & 3,68 & 1,3 \\
\hline 2011 & $\begin{array}{c}\text { WINERY } \\
44\end{array}$ & W44.5 & Serres - LW & 2009 & ROSE & $\begin{array}{c}\text { Semi-dry } \\
\text { wine }\end{array}$ & 14,06 & 13,38 & 3,7 & 5,3 & 132 & 37 & 3,34 & 11,4 \\
\hline 2011 & $\begin{array}{c}\text { WINERY } \\
49\end{array}$ & W49.3 & Serres - LW & 2009 & RED & Dry wine & 13,43 & 13,27 & 5 & 11,9 & 116 & 18 & 3,9 & 2,7 \\
\hline 2011 & $\begin{array}{c}\text { WINERY } \\
49\end{array}$ & W49.4 & Serres - LW & 2009 & WHITE & Dry wine & 13,78 & 13,68 & 5,4 & 3,7 & 141 & 24 & 3,2 & 1,7 \\
\hline 2011 & $\begin{array}{c}\text { WINERY } \\
49\end{array}$ & W49.5 & Serres - LW & 2008 & RED & Dry wine & 13,78 & 13,63 & 5,9 & 9,6 & 104 & 22 & 3,61 & 2,6 \\
\hline 2011 & $\begin{array}{c}\text { WINERY } \\
21\end{array}$ & W21.3 & Serres - LW & 2009 & RED & Dry wine & 13,76 & 13,6 & 6,49 & 10 & 86 & 19 & 3,23 & 2,6 \\
\hline 2011 & $\begin{array}{c}\text { WINERY } \\
21\end{array}$ & W21.4 & Serres - LW & 2010 & WHITE & Dry wine & 12,71 & 12,62 & 5,36 & 5,9 & 120 & 35 & 3,46 & 1,5 \\
\hline 2011 & $\begin{array}{c}\text { WINERY } \\
21\end{array}$ & W21.5 & & 2010 & WHITE & Dry wine & 12,85 & 12,76 & 5,1 & 6,4 & 102 & 27 & 3,52 & 1,6 \\
\hline 2011 & $\begin{array}{c}\text { WINERY } \\
21\end{array}$ & W21.6 & & 2010 & WHITE & Dry wine & 12,49 & 12,39 & 4,6 & 4,6 & 91 & 14,1 & 3,68 & 1,6 \\
\hline 2011 & $\begin{array}{c}\text { WINERY } \\
34\end{array}$ & W34.4 & Serres - LW & 2009 & RED & Dry wine & 15,34 & 15,21 & 5,6 & 6,2 & 94 & 54 & 3,65 & 2,2 \\
\hline 2011 & $\begin{array}{c}\text { WINERY } \\
34\end{array}$ & W34.5 & Serres - LW & 2009 & RED & Dry wine & 15,21 & 15,08 & 6,2 & 6,6 & 120 & 59 & 3,66 & 2,2 \\
\hline 2011 & $\begin{array}{c}\text { WINERY } \\
34\end{array}$ & W34.6 & Serres - LW & 2010 & WHITE & Dry wine & 13,78 & 13,64 & 5,2 & 8,1 & 172 & 65 & 3,75 & 2,4 \\
\hline 2011 & $\begin{array}{c}\text { WINERY } \\
34\end{array}$ & W34.7 & Serres - LW & 2009 & RED & Dry wine & 15,45 & 15,3 & 6,5 & 7,1 & 58 & 26 & 3,39 & 2,5 \\
\hline 2012 & $\begin{array}{c}\text { WINERY } \\
16\end{array}$ & W16.1 & & 2012 & WHITE & Dry wine & 14,86 & 14,67 & 4,9 & 5,6 & 102 & 15 & 3,63 & 3,1 \\
\hline 2012 & $\begin{array}{c}\text { WINERY } \\
16\end{array}$ & W16.2 & & 2010 & RED & Dry wine & 14,11 & 13,94 & 4,6 & 9,2 & 74 & 26 & 3,68 & 2,9 \\
\hline 2012 & $\begin{array}{c}\text { WINERY } \\
69\end{array}$ & W69.2 & Serres - LW & 2012 & WHITE & Dry wine & 12,59 & 12,44 & 5,2 & 9,6 & 161 & 9 & 3,62 & 2,5 \\
\hline 2012 & $\begin{array}{c}\text { WINERY } \\
46\end{array}$ & W46.5 & Serres - LW & 2011 & WHITE & Dry wine & 12,84 & 12,77 & 6,4 & 5,9 & 102 & 44 & 3,24 & 1,2 \\
\hline 2012 & $\begin{array}{c}\text { WINERY } \\
46\end{array}$ & W44.10 & Serres - LW & 2011 & WHITE & Dry wine & 14,06 & 13,97 & 5,6 & 6,2 & 109 & 45 & 3,44 & 1,6 \\
\hline 2012 & $\begin{array}{c}\text { WINERY } \\
46\end{array}$ & W46.6 & Serres - LW & 2011 & ROSE & $\begin{array}{c}\text { Semi-sweet } \\
\text { wine }\end{array}$ & 14,45 & 13,71 & 5,1 & 9,6 & 141 & 46 & 3,35 & 12,5 \\
\hline 2012 & $\begin{array}{c}\text { WINERY } \\
44\end{array}$ & W44.4 & Serres - LW & 2012 & WHITE & Dry wine & 13,76 & 13,69 & 4,85 & 6,1 & 118 & 46 & 3,39 & 1,3 \\
\hline 2012 & $\begin{array}{c}\text { WINERY } \\
2\end{array}$ & W2.5 & Serres - LW & 2008 & RED & Dry wine & 13,43 & 13,34 & 5,3 & 10 & 32 & 9,6 & 3,59 & 1,5 \\
\hline 2012 & $\begin{array}{c}\text { WINERY } \\
2 \\
\end{array}$ & W2.3 & Serres - LW & 2010 & ROSE & Dry wine & 15,61 & 15,52 & 5 & 9 & 31 & 11,5 & 3,58 & 1,6 \\
\hline
\end{tabular}




\begin{tabular}{|c|c|c|c|c|c|c|c|c|c|c|c|c|c|c|}
\hline 2012 & \begin{tabular}{|c|} 
WINERY \\
2
\end{tabular} & W2.6 & Serres - LW & 2011 & WHITE & Dry wine & 14,36 & 14,09 & 5 & 6 & 87 & 4 & 3,39 & 4,6 \\
\hline 2012 & $\begin{array}{c}\text { WINERY } \\
73\end{array}$ & W73.2 & Serres - LW & 2011 & WHITE & Dry wine & 12,89 & 12,81 & 6 & 5,4 & 175 & 30 & 3,35 & 1,4 \\
\hline 2012 & $\begin{array}{c}\text { WINERY } \\
73\end{array}$ & W73.1 & Serres - LW & 2011 & RED & Dry wine & 14,33 & 14,18 & 4,8 & 15,6 & 70 & 22 & 3,85 & 2,6 \\
\hline 2012 & $\begin{array}{c}\text { WINERY } \\
27\end{array}$ & W27.1 & Serres - LW & 2011 & RED & Dry wine & 13,64 & 13,53 & 4,6 & 8,5 & 108 & 24 & 3,8 & 1,9 \\
\hline 2012 & $\begin{array}{c}\text { WINERY } \\
27\end{array}$ & W27.2 & Serres - LW & 2011 & WHITE & Dry wine & 12,41 & 12,31 & 4,7 & 6 & 99 & 5 & 3,88 & 1,7 \\
\hline 2012 & $\begin{array}{c}\text { WINERY } \\
32\end{array}$ & W32.4 & Serres - LW & 2011 & WHITE & $\begin{array}{c}\text { Semi-dry } \\
\text { wine }\end{array}$ & 13,22 & 12,86 & 5,9 & 8,3 & 66 & 13 & 3,18 & 6,1 \\
\hline 2012 & $\begin{array}{c}\text { WINERY } \\
32\end{array}$ & W32.2 & Serres - LW & 2009 & RED & Dry wine & 13,04 & 12,92 & 5,4 & 13 & 96 & 19 & 3,49 & 1,9 \\
\hline 2012 & $\begin{array}{c}\text { WINERY } \\
30\end{array}$ & W30.1 & Serres - LW & 2011 & WHITE & Dry wine & 13,22 & 13,14 & 5,3 & 9,3 & 127 & 8 & 3,49 & 1,4 \\
\hline 2012 & $\begin{array}{c}\text { WINERY } \\
30\end{array}$ & W30.2 & Serres - LW & 2010 & RED & Dry wine & 13,77 & 13,67 & 5,9 & 12 & 56 & 19 & 3,5 & 1,8 \\
\hline 2012 & $\begin{array}{c}\text { WINERY } \\
21\end{array}$ & W21.5 & Serres - LW & 2011 & WHITE & Dry wine & 13,03 & 12,95 & 5,42 & 8,2 & 125 & 36 & 3,28 & 1,3 \\
\hline 2012 & $\begin{array}{c}\text { WINERY } \\
21\end{array}$ & W21.4 & Serres - LW & 2011 & WHITE & Dry wine & 13,07 & 12,99 & 5,33 & 6,8 & 116 & 37 & 3,44 & 1,4 \\
\hline 2012 & $\begin{array}{c}\text { WINERY } \\
21\end{array}$ & W21.3 & Serres - LW & 2010 & RED & Dry wine & 14,05 & 13,88 & 6,2 & 11 & 90 & 22 & 3,35 & 2,8 \\
\hline 2012 & $\begin{array}{c}\text { WINERY } \\
21\end{array}$ & W21.7 & Serres - LW & 2011 & RED & Dry wine & 13,44 & 13,31 & 6,4 & 8 & 84 & 29 & 3,36 & 2,1 \\
\hline 2012 & $\begin{array}{c}\text { WINERY } \\
64\end{array}$ & W64.1 & Serres - LW & 2011 & WHITE & Dry wine & 14,09 & 13,99 & 5 & 9,6 & 98,6 & 29 & 3,36 & 1,7 \\
\hline 2012 & $\begin{array}{c}\text { WINERY } \\
49\end{array}$ & W49.6 & $\begin{array}{c}\text { Macedonia } \\
-\mathrm{LW}\end{array}$ & 2010 & WHITE & Dry wine & 13,24 & 13,44 & 5,5 & 6,4 & 156 & 24 & 3,11 & 2,9 \\
\hline 2012 & $\begin{array}{c}\text { WINERY } \\
49\end{array}$ & W49.9 & $\begin{array}{c}\text { Macedonia } \\
\text { - LW }\end{array}$ & 2011 & ROSE & Dry wine & 14,06 & 13,85 & 5,8 & 8 & 131 & 27 & 3,34 & 4,07 \\
\hline 2012 & $\begin{array}{c}\text { WINERY } \\
49\end{array}$ & W49.7 & Serres - LW & 2010 & RED & Dry wine & 13,76 & 13,66 & 4,9 & 10,5 & 106 & 19 & 3,67 & 1,7 \\
\hline 2012 & $\begin{array}{c}\text { WINERY } \\
34\end{array}$ & W34.6 & Serres - LW & 2011 & WHITE & Dry wine & 12,8 & 12,68 & 5,8 & 3,7 & 124 & 26 & 3,4 & 2,1 \\
\hline 2012 & $\begin{array}{c}\text { WINERY } \\
34\end{array}$ & W34.8 & Serres - LW & 2011 & ROSE & $\begin{array}{c}\text { Semi-dry } \\
\text { wine }\end{array}$ & 13,44 & 13,07 & 6,4 & 9,4 & 129 & 33 & 3,21 & 6,2 \\
\hline 2012 & $\begin{array}{c}\text { WINERY } \\
34\end{array}$ & W34.4 & Serres - LW & 2010 & RED & Dry wine & 15,12 & 15,03 & 5,3 & 8,4 & 114 & 50 & 3,7 & 1,56 \\
\hline 2012 & $\begin{array}{c}\text { WINERY } \\
40\end{array}$ & W40.2 & Serres - LW & 2011 & WHITE & Dry wine & 12,51 & 12,42 & 4 & 13 & 47 & 6,4 & 3,54 & 1,5 \\
\hline 2013 & $\begin{array}{c}\text { WINERY } \\
49\end{array}$ & W49.9 & PGI Serres & & RED & $\begin{array}{c}\text { Semi-sweet } \\
\text { wine }\end{array}$ & 15,6 & 12,9 & 4,7 & 9,6 & 140 & 8 & 3,55 & 45,5 \\
\hline 2013 & $\begin{array}{c}\text { WINERY } \\
49\end{array}$ & W49.7 & PGI Serres & & RED & Dry wine & 13,39 & 13,3 & 4,9 & 9,5 & 80 & 24 & 3,76 & 1,6 \\
\hline 2013 & $\begin{array}{c}\text { WINERY } \\
32\end{array}$ & W32.3 & PGI Serres & 2012 & WHITE & Dry wine & 12,5 & 12,39 & 4,3 & 6,3 & 38 & 5 & 3,22 & 1,9 \\
\hline 2013 & $\begin{array}{c}\text { WINERY } \\
50\end{array}$ & W50.6 & Serres - LW & 2011 & WHITE & Dry wine & 12,58 & 12,46 & 5,6 & 4,8 & 134 & 27 & 3,57 & 2 \\
\hline 2013 & $\begin{array}{c}\text { WINERY } \\
40\end{array}$ & W40.2 & PGI Serres & 2012 & WHITE & Dry wine & 12,59 & 12,49 & 3,5 & 7,4 & 37 & 5 & 3,54 & 1,6 \\
\hline
\end{tabular}




\begin{tabular}{|c|c|c|c|c|c|c|c|c|c|c|c|c|c|c|}
\hline 2013 & $\begin{array}{c}\text { WINERY } \\
30\end{array}$ & W30.1 & PGI Serres & 2012 & WHITE & Dry wine & 13,49 & 13,37 & 5 & 5,9 & 121 & 5 & 3,37 & 2 \\
\hline 2013 & $\begin{array}{c}\text { WINERY } \\
30\end{array}$ & W30.2 & PGI Serres & 2011 & RED & Dry wine & 13,89 & 13,75 & 5,9 & 6,4 & 140 & 38 & 3,68 & 2,4 \\
\hline 2013 & $\begin{array}{c}\text { WINERY } \\
61\end{array}$ & W61.1 & PGI Serres & 2012 & WHITE & Dry wine & 13,25 & 13,15 & 5,2 & 3,9 & 132 & 19 & 3,38 & 1,6 \\
\hline 2013 & $\begin{array}{c}\text { WINERY } \\
61\end{array}$ & W61.2 & PGI Serres & 2011 & RED & Dry wine & 13,07 & 12,95 & 5,5 & 8,8 & 110 & 29 & 3,51 & 1,9 \\
\hline 2013 & $\begin{array}{c}\text { WINERY } \\
2\end{array}$ & W2.2 & PGI Serres & 2012 & WHITE & Dry wine & 12,61 & 12,52 & 4,7 & 6,7 & 32 & 9 & 3,46 & 1,5 \\
\hline 2013 & $\begin{array}{c}\text { WINERY } \\
2\end{array}$ & W2.3 & PGI Serres & 2012 & ROSE & Dry wine & 14 & 13,91 & 6,7 & 5 & 58 & 9 & 3,22 & 1,5 \\
\hline 2013 & $\begin{array}{c}\text { WINERY } \\
46\end{array}$ & W46.5 & PGI Serres & 2012 & WHITE & Dry wine & 13,72 & 13,58 & 4,6 & 6 & 116 & 65 & 3,47 & 2,3 \\
\hline 2013 & $\begin{array}{c}\text { WINERY } \\
46\end{array}$ & W44.10 & PGI Serres & 2012 & WHITE & Dry wine & 12,85 & 12,74 & 3,5 & 6,2 & 85 & 21 & 3,6 & 1,9 \\
\hline 2013 & $\begin{array}{c}\text { WINERY } \\
46\end{array}$ & W46.6 & PGI Serres & 2012 & ROSE & $\begin{array}{l}\text { Semi-dry } \\
\text { wine }\end{array}$ & 14,12 & 13,68 & 5,3 & 6,2 & 152 & 54 & 3,35 & 7,4 \\
\hline 2013 & $\begin{array}{c}\text { WINERY } \\
46\end{array}$ & W46.7 & PGI Serres & 2010 & RED & Dry wine & 13,52 & 13,3 & 5,3 & 7,9 & 92 & 32 & 3,63 & 3,8 \\
\hline 2013 & $\begin{array}{c}\text { WINERY } \\
34\end{array}$ & W34.6 & PGI Serres & 2012 & WHITE & Dry wine & 13,28 & 13,17 & 5 & 5,2 & 196 & 49 & 3,61 & 1,8 \\
\hline 2013 & $\begin{array}{c}\text { WINERY } \\
34\end{array}$ & W34.4 & PGI Serres & 2012 & RED & Dry wine & 14,25 & 14,14 & 6,1 & 4,5 & 164 & 45 & 3,57 & 1,8 \\
\hline 2013 & $\begin{array}{c}\text { WINERY } \\
43\end{array}$ & W43.1 & PGI Serres & 2012 & WHITE & Dry wine & 13,08 & 12,99 & 4 & 8,8 & 148 & 13 & 3,75 & 1,5 \\
\hline 2013 & $\begin{array}{c}\text { WINERY } \\
43\end{array}$ & W43.2 & PGI Serres & 2012 & ROSE & $\left|\begin{array}{c}\text { Semi-sweet } \\
\text { wine }\end{array}\right|$ & 12,55 & 11,7 & 4,4 & 7,8 & 97 & 19 & 3,6 & 14,3 \\
\hline 2013 & $\begin{array}{c}\text { WINERY } \\
43\end{array}$ & W43.3 & PGI Serres & 2012 & RED & Dry wine & 12,15 & 12,03 & 4,8 & 6,1 & 84 & 32 & 3,6 & 2 \\
\hline 2013 & $\begin{array}{c}\text { WINERY } \\
69\end{array}$ & W69.2 & PGI Serres & 2012 & WHITE & Dry wine & 11,61 & 11,53 & 4,8 & 8,5 & 147 & 10 & 3,52 & 1,3 \\
\hline 2013 & $\begin{array}{c}\text { WINERY } \\
69\end{array}$ & W69.4 & PGI Serres & 2012 & RED & Sweet wine & 13,85 & 10,88 & 5,4 & 29,4 & 86 & 19 & 4,03 & 50 \\
\hline 2013 & $\begin{array}{c}\text { WINERY } \\
69\end{array}$ & W69.3 & PGI Serres & 2012 & RED & $\begin{array}{l}\text { Semi-dry } \\
\text { wine }\end{array}$ & 13,66 & 13,29 & 4,5 & 14,5 & 58 & 16 & 3,81 & 6,3 \\
\hline 2013 & $\begin{array}{c}\text { WINERY } \\
73\end{array}$ & W73.3 & PGI Serres & 2012 & WHITE & Dry wine & 13,3 & 13,21 & 4,9 & 7,5 & 48 & 11 & 3,48 & 1,5 \\
\hline 2013 & $\begin{array}{c}\text { WINERY } \\
73\end{array}$ & W73.4 & PGI Serres & 2012 & RED & Dry wine & 13,62 & 13,48 & 5,2 & 12,7 & 110 & 48 & 3,67 & 2,3 \\
\hline 2013 & $\begin{array}{c}\text { WINERY } \\
27\end{array}$ & W27.3 & $\begin{array}{c}\text { PGI } \\
\text { Macedonia }\end{array}$ & 2012 & WHITE & Dry wine & 12,52 & 12,44 & 5,7 & 6,3 & 83 & 24 & 3,24 & 1,4 \\
\hline 2013 & $\begin{array}{c}\text { WINERY } \\
27\end{array}$ & W27.1 & PGI Serres & 2012 & RED & Dry wine & 13,49 & 13,39 & 6,1 & 7,6 & 108 & 26 & 3,56 & 1,8 \\
\hline 2013 & $\begin{array}{c}\text { WINERY } \\
26\end{array}$ & W26.1 & $\begin{array}{l}\text { Organic } \\
\text { Varietal } \\
\text { wine }\end{array}$ & 2012 & WHITE & Dry wine & 13,62 & 13,51 & 5,6 & 7 & 129 & 43 & 3,29 & 1,9 \\
\hline 2013 & $\begin{array}{c}\text { WINERY } \\
26\end{array}$ & W26.2 & $\begin{array}{c}\text { Organic } \\
\text { Varietal } \\
\text { wine }\end{array}$ & 2012 & WHITE & Dry wine & 13,05 & 12,93 & 5 & 8,1 & 88 & 28 & 3,42 & 2,1 \\
\hline
\end{tabular}




\begin{tabular}{|c|c|c|c|c|c|c|c|c|c|c|c|c|c|c|c|c|}
\hline 2013 & $\begin{array}{c}\text { WINERY } \\
26\end{array}$ & W26.3 & $\begin{array}{c}\text { Organic } \\
\text { Varietal } \\
\text { wine }\end{array}$ & 2012 & ROSE & $\begin{array}{c}\text { Semi-sweet } \\
\text { wine }\end{array}$ & 13,75 & 12,99 & 6,1 & 7,8 & 138 & 27 & 3,31 & & & 12,8 \\
\hline 2013 & $\begin{array}{c}\text { WINERY } \\
16\end{array}$ & W16.3 & PGI Serres & 2010 & RED & Dry wine & 14,18 & 14,09 & 5 & 9,7 & 48 & 26 & 3,47 & & & 1,6 \\
\hline 2013 & $\begin{array}{c}\text { WINERY } \\
16\end{array}$ & W16.4 & PGI Serres & 2010 & RED & Dry wine & 13,9 & 13,77 & 4,8 & 12 & 72 & 19 & 3,64 & & & 2,3 \\
\hline 2013 & $\begin{array}{c}\text { WINERY } \\
21\end{array}$ & W21.8 & PGI Serres & 2012 & WHITE & Dry wine & 12,63 & 12,52 & 4,9 & 7 & 96 & 32 & 3,32 & & & 1,8 \\
\hline 2013 & $\begin{array}{c}\text { WINERY } \\
21\end{array}$ & W21.9 & PGI Serres & 2012 & WHITE & Dry wine & 12,49 & 12,41 & 5,2 & 6,7 & 104 & 28 & 3,23 & & & 1,4 \\
\hline 2013 & $\begin{array}{c}\text { WINERY } \\
64\end{array}$ & W64.1 & PGI Serres & 2011 & WHITE & Dry wine & 14,19 & 14,11 & 4,5 & 8,5 & 115 & 27 & 3,46 & & & 1,4 \\
\hline 2014 & $\begin{array}{c}\text { WINERY } \\
69\end{array}$ & W69.3 & PGI Serres & 2013 & RED & Dry wine & 12,73 & 12,66 & 4,8 & 9,3 & 62 & 15 & 3,7 & 0,995 & 33,6 & 1,2 \\
\hline 2014 & $\begin{array}{c}\text { WINERY } \\
69\end{array}$ & W69.2 & PGI Serres & 2013 & WHITE & Dry wine & 12,26 & 12,16 & 4,7 & 5,8 & 141 & 12 & 3,45 & 0,991 & 21,9 & 1,7 \\
\hline 2014 & $\begin{array}{c}\text { WINERY } \\
32\end{array}$ & W32.3 & PGI Serres & 2013 & WHITE & Dry wine & 12,85 & 12,79 & 4,9 & 5,3 & 113 & 44 & 3,47 & 0,989 & 18,8 & 1,1 \\
\hline 2014 & $\begin{array}{c}\text { WINERY } \\
34\end{array}$ & W34.5 & PGI Serres & 2013 & RED & Dry wine & 14,29 & 14,16 & 5,7 & 4,4 & 126 & 29 & 3,65 & 0,992 & 31,3 & 2,2 \\
\hline 2014 & $\begin{array}{c}\text { WINERY } \\
34\end{array}$ & W34.6 & PGI Serres & 2013 & WHITE & Dry wine & 13,34 & 13,28 & 4,6 & 6,2 & 135 & 21 & 3,84 & 0,99 & 22,7 & 1,1 \\
\hline 2014 & $\begin{array}{c}\text { WINERY } \\
46\end{array}$ & W46.13 & PGI Serres & 2013 & ROSE & $\begin{array}{l}\text { Semi-dry } \\
\text { wine }\end{array}$ & 14,26 & 13,87 & 4,8 & 8,7 & 185 & 26 & 3,55 & 0,991 & 27,9 & 6,5 \\
\hline 2014 & $\begin{array}{c}\text { WINERY } \\
46\end{array}$ & W44.10 & PGI Serres & 2013 & WHITE & Dry wine & 12,93 & 12,86 & 4,6 & 3,5 & 171 & 53 & 3,46 & 0,989 & 19,8 & 1,2 \\
\hline 2014 & $\begin{array}{c}\text { WINERY } \\
46\end{array}$ & W46.5 & PGI Serres & 2013 & WHITE & Dry wine & 13,19 & 13,09 & 4,5 & 4,3 & 149 & 51 & 3,42 & 0,988 & 18,3 & 1,7 \\
\hline 2014 & $\begin{array}{c}\text { WINERY } \\
44\end{array}$ & W44.4 & PGI Serres & 2013 & WHITE & Dry wine & 13,21 & 13,14 & 4,2 & 3,1 & 156 & 46 & 3,51 & 0,988 & 18,5 & 1,1 \\
\hline 2014 & $\begin{array}{c}\text { WINERY } \\
21\end{array}$ & W21.9 & PGI Serres & 2013 & WHITE & Dry wine & 12,6 & 12,52 & 4,4 & 2,7 & 106 & 26 & 3,54 & 0,997 & 46,5 & 1,4 \\
\hline 2014 & $\begin{array}{c}\text { WINERY } \\
21\end{array}$ & W21.8 & PGI Serres & 2014 & WHITE & Dry wine & 13,4 & 13,31 & 3,9 & 5,5 & 103 & 20 & 3,69 & 0,998 & 45,3 & 1,5 \\
\hline 2014 & $\begin{array}{c}\text { WINERY } \\
21\end{array}$ & W21.7 & PGI Serres & & RED & Dry wine & 13,59 & 13,42 & 5,6 & 7,1 & 94 & 20 & 3,47 & 0,992 & 29,4 & 2,9 \\
\hline 2014 & $\begin{array}{c}\text { WINERY } \\
26\end{array}$ & W26.5 & PGI Drama & 2012 & RED & Dry wine & 13,91 & 13,74 & 5,2 & 9 & 66 & 19 & 3,69 & & & 2,8 \\
\hline 2015 & $\begin{array}{c}\text { WINERY } \\
46\end{array}$ & W44.12 & PGI Serres & 2014 & ROSE & Dry wine & 13,01 & 12,9 & 3,6 & 8 & 104 & 37 & 3,73 & 0,989 & 20,3 & 1,9 \\
\hline 2015 & $\begin{array}{c}\text { WINERY } \\
46\end{array}$ & W46.6 & PGI Serres & 2014 & ROSE & $\mid \begin{array}{c}\text { Semi-sweet } \\
\text { wine }\end{array}$ & 14,68 & 12,51 & 4,38 & 8,1 & 110 & 33 & 3,64 & 1,003 & 54,6 & 36,6 \\
\hline 2015 & $\begin{array}{c}\text { WINERY } \\
46\end{array}$ & W44.10 & PGI Serres & 2014 & WHITE & Dry wine & 12,48 & 12,33 & 5,5 & 4 & 129 & 17 & 3,51 & 0,991 & 24,2 & 2,5 \\
\hline 2015 & $\begin{array}{c}\text { WINERY } \\
46\end{array}$ & W46.5 & PGI Serres & 2014 & WHITE & Dry wine & 12,28 & 12,15 & 5,5 & 5,1 & 110 & 15 & 3,4 & 0,991 & 22,2 & 2,2 \\
\hline 2015 & \begin{tabular}{|c|} 
WINERY \\
26
\end{tabular} & W26.7 & $\begin{array}{l}\text { Varietal } \\
\text { wine }\end{array}$ & 2013 & RED & Dry wine & 13,89 & 13,68 & 5,1 & 11,2 & 99 & 23 & 3,66 & 0,993 & 31 & 3,5 \\
\hline 2015 & \begin{tabular}{|c} 
WINERY \\
26
\end{tabular} & W26.4 & $\begin{array}{c}\text { Varietal } \\
\text { wine }\end{array}$ & 2013 & ROSE & $\begin{array}{c}\text { Semi-dry } \\
\text { wine }\end{array}$ & 13,79 & 13,01 & 5,01 & 6,3 & 103 & 19 & 3,43 & 0,994 & 34,1 & 13,1 \\
\hline
\end{tabular}




\begin{tabular}{|c|c|c|c|c|c|c|c|c|c|c|c|c|c|c|c|c|}
\hline 2015 & \begin{tabular}{|c} 
WINERY \\
26
\end{tabular} & W26.8 & $\begin{array}{c}\text { Varietal } \\
\text { wine }\end{array}$ & 2014 & WHITE & Dry wine & 13,54 & 13,36 & 5,6 & 5,2 & 104 & 13 & 3,28 & 0,99 & 24,2 & 3,1 \\
\hline 2015 & $\begin{array}{c}\text { WINERY } \\
40\end{array}$ & W40.4 & PGI Serres & 2012 & RED & Dry wine & 13,31 & 13,16 & 5,3 & 9,3 & 74 & 21 & 3,64 & 0,992 & 28,7 & 2,6 \\
\hline 2015 & $\begin{array}{c}\text { WINERY } \\
40\end{array}$ & W40.5 & PGI Serres & 2011 & RED & Dry wine & 13,21 & 13,04 & 5,5 & 8,3 & 68 & 13 & 3,61 & 0,993 & 31 & 2,9 \\
\hline 2015 & $\begin{array}{c}\text { WINERY } \\
40\end{array}$ & W40.1 & PGI Serres & 2014 & WHITE & Dry wine & 11,55 & 11,47 & 5,4 & 3,8 & 60 & 5 & 3,43 & 0,99 & 17,7 & 1,3 \\
\hline 2015 & $\begin{array}{c}\text { WINERY } \\
51\end{array}$ & W51.1 & PGI Serres & 2014 & WHITE & Dry wine & 13,17 & 13 & 6 & 4,8 & 138 & 16 & 3,4 & 0,991 & 25,3 & 2,9 \\
\hline 2015 & $\begin{array}{c}\text { WINERY } \\
48\end{array}$ & W48.1 & PGI Serres & 2014 & WHITE & Dry wine & 12,48 & 12,4 & 4,4 & 4,5 & 42 & 6 & 3,71 & 0,99 & 19 & 1,3 \\
\hline 2015 & $\begin{array}{c}\text { WINERY } \\
48\end{array}$ & W48.2 & $\begin{array}{l}\text { Organic } \\
\text { wine }\end{array}$ & 2014 & RED & Dry wine & 13,84 & 13,68 & 4,1 & 10,1 & 129 & 37 & 3,86 & 0,992 & 29,2 & 2,7 \\
\hline 2015 & $\begin{array}{c}\text { WINERY } \\
30\end{array}$ & W30.3 & PGI Serres & 2014 & WHITE & Dry wine & 12,8 & 12,65 & 5,9 & 6,7 & 148 & 20 & 3,12 & 0,99 & 21,6 & 2,5 \\
\hline 2015 & $\begin{array}{c}\text { WINERY } \\
30\end{array}$ & W30.2 & PGI Serres & 2013 & RED & Dry wine & 13,47 & 13,3 & 4,5 & 10 & 102 & 24 & 3,7 & 0,993 & 30,5 & 2,9 \\
\hline 2015 & $\begin{array}{c}\text { WINERY } \\
27\end{array}$ & W27.2 & PGI Serres & 2014 & WHITE & Dry wine & 12,62 & 12,5 & 5,4 & 2,3 & 112 & 31 & 3,53 & 0,99 & 21,6 & 2 \\
\hline 2015 & $\begin{array}{c}\text { WINERY } \\
27\end{array}$ & W27.1 & PGI Serres & 2014 & RED & Dry wine & 13,34 & 13,2 & 5,5 & 3,9 & 124 & 19 & 3,59 & 0,992 & 27,9 & 2,3 \\
\hline 2015 & $\begin{array}{c}\text { WINERY } \\
2\end{array}$ & W2.2 & PGI Serres & 2014 & WHITE & Dry wine & 12,25 & 12,17 & 5,7 & 2,5 & 48 & 5 & 3,43 & 0,991 & 21,6 & 1,4 \\
\hline 2015 & $\begin{array}{c}\text { WINERY } \\
2\end{array}$ & W2.3 & PGI Serres & 2014 & ROSE & Dry wine & 13,68 & 13,6 & 5,9 & 3,7 & 45 & 6 & 3,45 & 0,989 & 22,4 & 1,3 \\
\hline 2015 & $\begin{array}{c}\text { WINERY } \\
2\end{array}$ & W2.5 & PGI Serres & 2014 & RED & Dry wine & 14,06 & 13,92 & 4,9 & 12,7 & 78 & 25 & 3,73 & 0,991 & 27,6 & 2,3 \\
\hline 2015 & $\begin{array}{c}\text { WINERY } \\
2\end{array}$ & W2.4 & PGI Serres & 2014 & RED & Dry wine & 14,17 & 14 & 4,6 & 10,2 & 85 & 31 & 3,71 & 0,991 & 28,7 & 2,9 \\
\hline 2015 & $\begin{array}{c}\text { WINERY } \\
61\end{array}$ & W61.1 & PGI Serres & 2014 & WHITE & Dry wine & 12,5 & 12,42 & 4,6 & 1,9 & 109 & 17 & 3,64 & 0,99 & 20,6 & 1,3 \\
\hline 2015 & $\begin{array}{c}\text { WINERY } \\
61\end{array}$ & W61.2 & PGI Serres & 2014 & RED & Dry wine & 14,01 & 13,87 & 5,5 & 8,7 & 108 & 19 & 3,5 & 0,992 & 31,3 & 2,4 \\
\hline 2016 & $\begin{array}{c}\text { WINERY } \\
21\end{array}$ & W21.9 & PGI Serres & 2015 & WHITE & Dry wine & 13,21 & 13,09 & 4,9 & 7,1 & 109 & 15 & 3,55 & 0,989 & 21,1 & 2 \\
\hline 2016 & $\begin{array}{c}\text { WINERY } \\
21\end{array}$ & W21.7 & PGI Serres & 2014 & RED & Dry wine & 13,89 & 13,69 & 4,7 & 9,3 & 76 & 15 & 3,69 & 0,993 & 32 & 3,3 \\
\hline 2016 & $\begin{array}{c}\text { WINERY } \\
26\end{array}$ & W26.8 & $\begin{array}{l}\text { Varietal } \\
\text { wine }\end{array}$ & 2015 & WHITE & Dry wine & 14,05 & 13,86 & 5,6 & 4,5 & 84 & 12 & 3,08 & 0,989 & 21,4 & 3,2 \\
\hline 2016 & $\begin{array}{c}\text { WINERY } \\
26\end{array}$ & W26.9 & $\begin{array}{l}\text { Varietal } \\
\text { wine }\end{array}$ & 2015 & RED & $\begin{array}{c}\text { Semi-sweet } \\
\text { wine }\end{array}$ & 14,39 & 12,44 & 3,4 & 10,7 & 150 & 16 & 3,71 & 1,007 & 65,7 & 32,8 \\
\hline 2016 & $\begin{array}{c}\text { WINERY } \\
44\end{array}$ & W44.5 & PGI Serres & 2015 & ROSE & $\begin{array}{c}\text { Semi-dry } \\
\text { wine }\end{array}$ & 14,49 & 13,94 & 4,6 & 8 & 154 & 45 & 3,63 & 0,993 & 31,3 & 9,2 \\
\hline 2016 & $\begin{array}{c}\text { WINERY } \\
44\end{array}$ & W44.6 & PGI Serres & 2011 & RED & Dry wine & 15,08 & 14,9 & 4,5 & 9 & 82 & 21 & 3,57 & 0,99 & 28,4 & 3 \\
\hline 2016 & $\begin{array}{c}\text { WINERY } \\
32\end{array}$ & W32.3 & PGI Serres & 2015 & WHITE & Dry wine & 12,62 & 12,42 & 5,2 & 6,1 & 131 & 5 & 3,15 & 0,99 & 20,6 & 3,4 \\
\hline 2016 & $\begin{array}{c}\text { WINERY } \\
32\end{array}$ & W32.5 & PGI Serres & 2015 & ROSE & $\begin{array}{c}\text { Semi-sweet } \\
\text { wine }\end{array}$ & 13,54 & 12,29 & 5,4 & 5,9 & 89 & 12 & 3,29 & 0,999 & 42,6 & 21 \\
\hline 2016 & $\begin{array}{c}\text { WINERY } \\
27\end{array}$ & W27.4 & $\begin{array}{c}\text { PGI } \\
\text { Macedonia }\end{array}$ & 2015 & WHITE & Dry wine & 12,02 & 11,9 & 5 & 3,8 & 175 & 38 & 3,45 & 0,99 & 19,3 & 2 \\
\hline
\end{tabular}




\begin{tabular}{|c|c|c|c|c|c|c|c|c|c|c|c|c|c|c|c|c|c|c|}
\hline 2016 & \begin{tabular}{|c} 
WINERY \\
27
\end{tabular} & W27.5 & $\begin{array}{c}\text { PGI } \\
\text { Macedonia }\end{array}$ & & 2015 & ROSE & Dry wine & 12,36 & 12,26 & 5,4 & 2,2 & 140 & 14 & & 3,74 & 0,991 & 24,2 & 1,6 \\
\hline 2016 & $\begin{array}{c}\text { WINERY } \\
27\end{array}$ & W27.1 & PGI Serres & & 2014 & RED & Dry wine & 12,96 & 12,83 & 5,9 & 8,2 & 53 & 7 & & 3,66 & 0,991 & 23,5 & 2,2 \\
\hline 2016 & $\begin{array}{c}\text { WINERY } \\
46\end{array}$ & W44.10 & PGI Serres & & 2015 & WHITE & Dry wine & 13,2 & 13,12 & 5,1 & 3,5 & 147 & 58 & & 3,44 & 0,989 & 20,3 & 1,4 \\
\hline 2016 & $\begin{array}{c}\text { WINERY } \\
46\end{array}$ & W44.12 & PGI Serres & & 2015 & ROSE & Dry wine & 13,51 & 13,43 & 4,9 & 6,3 & 109 & 16 & & 3,36 & 0,983 & 19,3 & 1,4 \\
\hline 2016 & $\begin{array}{c}\text { WINERY } \\
50\end{array}$ & W50.6 & PGI Serres & & 2015 & WHITE & Dry wine & 13,35 & 13,25 & 5,7 & 4,8 & 101 & 21 & & 3,62 & 0,99 & 24,2 & 1,7 \\
\hline 2016 & $\begin{array}{c}\text { WINERY } \\
50\end{array}$ & W50.7 & PGI Serres & & 2012 & RED & $\begin{array}{c}\text { Semi-sweet } \\
\text { wine }\end{array}$ & 13,87 & 12,34 & 5,6 & 20,1 & 84 & 18 & & 3,89 & 1,01 & 72,5 & 25,7 \\
\hline 2016 & $\begin{array}{c}\text { WINERY } \\
14\end{array}$ & W14.1 & & Wine tanks & 2015 & WHITE & Dry wine & 11,67 & 11,57 & 6 & 3,6 & 140 & 28 & & 3,29 & 0,991 & 21,9 & 1,6 \\
\hline 2016 & $\begin{array}{c}\text { WINERY } \\
14\end{array}$ & W14.2 & & Wine tanks & 2015 & RED & Dry wine & 13,59 & 13,41 & 4,5 & 9,9 & 118 & 37 & & 3,65 & 0,991 & 26,8 & 3,1 \\
\hline 2016 & $\begin{array}{c}\text { WINERY } \\
30\end{array}$ & W30.1 & PGI Serres & & 2015 & WHITE & Dry wine & 12,54 & 12,43 & 5,2 & 4,2 & 86 & 17 & & 3,58 & 0,99 & 21,9 & 1,9 \\
\hline 2016 & $\begin{array}{c}\text { WINERY } \\
30\end{array}$ & W30.4 & PGI Serres & & 2015 & ROSE & Dry wine & 12,56 & 12,44 & 4,4 & 9,4 & 91 & 12 & & 3,55 & 0,989 & 20,1 & 2 \\
\hline 2016 & $\begin{array}{c}\text { WINERY } \\
30\end{array}$ & W30.2 & PGI Serres & & 2013 & RED & Dry wine & 13,81 & 13,65 & 4 & 11,5 & 129 & 27 & & 3,71 & 0,993 & 32,3 & 2,7 \\
\hline 2016 & $\begin{array}{c}\text { WINERY } \\
34\end{array}$ & W34.6 & PGI Serres & & 2015 & WHITE & Dry wine & 14,19 & 14,04 & 5,4 & 7 & 201 & 96 & & 3,33 & 0,989 & 22,9 & 2,5 \\
\hline 2016 & $\begin{array}{c}\text { WINERY } \\
34\end{array}$ & W34.9 & PGI Serres & & 2015 & WHITE & Dry wine & 13,75 & 13,6 & 5,1 & 5,8 & 204 & 93 & & 3,59 & 0,99 & 25,3 & 2,6 \\
\hline 2016 & $\begin{array}{c}\text { WINERY } \\
34\end{array}$ & W34.8 & PGI Serres & & 2015 & ROSE & $\begin{array}{c}\text { Semi-dry } \\
\text { wine }\end{array}$ & 13,87 & 13,58 & 5,8 & 5,3 & 189 & 85 & & 3,3 & 0,99 & 25,5 & 4,8 \\
\hline 2016 & $\begin{array}{c}\text { WINERY } \\
48\end{array}$ & W48.1 & PGI Serres & & 2015 & WHITE & Dry wine & 12,72 & 12,65 & 6,7 & 3 & 82 & 13 & & 3,41 & 0,991 & 23,7 & 1,2 \\
\hline 2016 & $\begin{array}{c}\text { WINERY } \\
48\end{array}$ & W48.4 & PGI Serres & & 2015 & RED & Dry wine & 13,58 & 13,44 & 5,2 & 6,1 & 79 & 21 & & 3,63 & 0,991 & 27,6 & 2,4 \\
\hline 2016 & $\begin{array}{c}\text { WINERY } \\
68\end{array}$ & W68.1 & & & 2015 & RED & Dry wine & 13,34 & 13,17 & 4,6 & 7,8 & 42 & 12 & & 3,71 & 0,992 & 28,7 & 2,8 \\
\hline 2016 & $\begin{array}{c}\text { WINERY } \\
59\end{array}$ & W59.1 & & & 2008 & RED & Dry wine & 13,18 & 12,99 & 6,6 & 7,9 & 61 & 10 & & 3,3 & 0,994 & 32 & 3,2 \\
\hline 2017 & $\begin{array}{c}\text { WINERY } \\
44\end{array}$ & W44.7 & PGI Serres & & 2016 & ROSE & $\begin{array}{l}\text { Semi-dry } \\
\text { wine }\end{array}$ & 13,97 & 13,4 & 3,8 & 8 & 86 & 17 & 145 & 3,57 & 0,991 & 27,4 & 9,6 \\
\hline 2017 & $\begin{array}{c}\text { WINERY } \\
27\end{array}$ & W27.6 & & & 2016 & WHITE & Dry wine & 12,44 & 12,3 & 5,3 & 5,4 & 134 & 40 & 2 & 3,37 & 0,99 & 19,8 & 2,3 \\
\hline 2017 & $\begin{array}{c}\text { WINERY } \\
22\end{array}$ & W22.1 & & & 2017 & WHITE & Dry wine & 11,6 & 11,45 & 4,6 & 3,3 & 153 & 31 & 2 & 3,48 & 0,99 & 20,1 & 2,6 \\
\hline 2017 & $\begin{array}{c}\text { WINERY } \\
27\end{array}$ & W27.7 & & & 2016 & RED & Dry wine & 12,05 & 11,79 & 5,6 & 3 & 159 & 45 & 0 & 3,3 & 0,992 & 22,9 & 4,3 \\
\hline 2017 & $\begin{array}{c}\text { WINERY } \\
34\end{array}$ & W34.9 & PGI Serres & & 2016 & WHITE & Dry wine & 13,46 & 13,33 & 5,4 & 5,5 & 214 & 92 & 2 & 3,12 & 0,989 & 19,8 & 2,2 \\
\hline 2017 & $\begin{array}{c}\text { WINERY } \\
34\end{array}$ & W34.6 & PGI Serres & & 2016 & WHITE & Dry wine & 13,21 & 13,09 & 5,5 & 5,8 & 142 & 37 & 1 & 3,49 & 0,99 & 23,2 & 2,1 \\
\hline 2017 & $\begin{array}{c}\text { WINERY } \\
34\end{array}$ & W34.6 & PGI Serres & & 2014 & WHITE & Dry wine & 14,87 & 14,7 & 4,7 & 7,6 & 160 & 47 & 5 & 3,77 & 0,99 & 31,5 & 2,9 \\
\hline 2017 & $\begin{array}{c}\text { WINERY } \\
51\end{array}$ & W51.2 & PGI Serres & & 2015 & RED & Dry wine & 13,97 & 13,73 & 5,6 & 9,5 & 65 & 15 & 2 & 3,52 & 0,995 & 36,5 & 4,1 \\
\hline
\end{tabular}




\begin{tabular}{|c|c|c|c|c|c|c|c|c|c|c|c|c|c|c|c|c|c|c|}
\hline 2017 & $\begin{array}{c}\text { WINERY } \\
16\end{array}$ & W16.7 & \begin{tabular}{|c|} 
Traditional \\
Appellation, \\
Retsina
\end{tabular} & & 2016 & WHITE & Dry wine & 12,05 & 11,92 & 4,7 & 4,8 & 131 & 20 & 81 & 3,45 & 0,99 & 20,6 & 2,2 \\
\hline 2017 & $\begin{array}{c}\text { WINERY } \\
16\end{array}$ & W16.5 & & & 2016 & RED & Dry wine & 13,49 & 13,29 & 4 & 5,4 & 93 & 35 & 2 & 3,86 & 0,992 & 30 & 3,4 \\
\hline 2017 & $\begin{array}{c}\text { WINERY } \\
16\end{array}$ & W16.6 & & & 2016 & WHITE & Dry wine & 12,08 & 11,99 & 5,1 & 5,7 & 116 & 25 & 35 & 3,43 & 0,99 & 19,3 & 1,5 \\
\hline 2017 & $\begin{array}{c}\text { WINERY } \\
30\end{array}$ & W30.1 & PGI Serres & & 2016 & WHITE & Dry wine & 12,96 & 12,81 & 4,4 & 5,3 & 72 & 18 & 1 & 3,46 & 0,99 & 21,4 & 2,6 \\
\hline 2017 & $\begin{array}{c}\text { WINERY } \\
40\end{array}$ & W40.1 & PGI Serres & & 2016 & WHITE & Dry wine & 12,07 & 11,99 & 5 & 6,1 & 108 & 5 & 2 & 3,27 & 0,989 & 17,7 & 1,3 \\
\hline 2017 & $\begin{array}{c}\text { WINERY } \\
40\end{array}$ & W40.4 & PGI Serres & & 2016 & RED & Dry wine & 13,23 & 13,06 & 5,1 & 9,5 & 80 & 13 & 2 & 3,59 & 0,992 & 28,4 & 2,9 \\
\hline 2017 & $\begin{array}{c}\text { WINERY } \\
64\end{array}$ & W64.1 & PGI Serres & & 2016 & WHITE & Dry wine & 12,91 & 12,77 & 5,1 & 7,7 & 60 & 13 & 3 & 3,4 & 0,99 & 20,9 & 2,4 \\
\hline 2018 & $\begin{array}{c}\text { WINERY } \\
45\end{array}$ & W45.1 & PGI Serres & & 2017 & RED & Dry wine & 13,24 & 13,12 & 3,9 & 7,9 & 64 & 13 & 2 & 3,92 & 0,991 & 24,5 & 2,1 \\
\hline 2018 & $\begin{array}{c}\text { WINERY } \\
45\end{array}$ & W45.2 & PGI Serres & & 2018 & WHITE & Dry wine & 13,4 & 13,32 & 4,99 & 2,6 & 132 & 6 & 2 & 3,54 & 0,988 & 19,3 & 1,3 \\
\hline 2018 & $\begin{array}{c}\text { WINERY } \\
16\end{array}$ & W16.7 & $\begin{array}{c}\text { Traditional } \\
\text { Appellation, } \\
\text { Retsina }\end{array}$ & Wine tanks & 2018 & WHITE & Dry wine & 11,33 & 11,23 & 5,25 & 3 & 104 & 24 & 6 & 3,49 & 0,992 & 21,6 & 1,7 \\
\hline 2018 & $\begin{array}{c}\text { WINERY } \\
27\end{array}$ & W27.8 & & & 2018 & RED & Dry wine & 13,82 & 13,66 & 4,39 & 8,9 & 77 & 25 & 0 & 3,84 & 0,992 & 28,4 & 2,7 \\
\hline 2018 & \begin{tabular}{|c|} 
WINERY \\
27
\end{tabular} & W27.9 & & & 2017 & RED & Dry wine & 13,78 & 13,68 & 4,78 & 6,1 & 155 & 47 & 3 & 3,43 & 0,988 & 19 & 1,6 \\
\hline 2018 & $\begin{array}{c}\text { WINERY } \\
27\end{array}$ & W27.10 & & & 2017 & RED & Dry wine & 11,97 & 11,87 & 5,12 & 4,7 & 198 & 51 & 3 & 3,17 & 0,989 & 17,7 & 1,7 \\
\hline 2018 & $\begin{array}{c}\text { WINERY } \\
21\end{array}$ & W21.7 & PGI Serres & & 2015 & RED & Dry wine & 14,77 & 14,63 & 4,76 & 7,5 & 82 & 21 & 1 & 3,84 & 0,991 & 30,7 & 2,3 \\
\hline 2018 & $\begin{array}{c}\text { WINERY } \\
21\end{array}$ & W21.8 & PGI Serres & & 2017 & WHITE & Dry wine & 13,26 & 13,18 & 3,92 & 8,1 & 119 & 15 & 8 & 3,84 & 0,989 & 20,1 & 1,4 \\
\hline 2018 & $\begin{array}{c}\text { WINERY } \\
21\end{array}$ & W21.5 & & & 2017 & WHITE & Dry wine & 13,17 & 13,06 & 5,1 & 6,3 & 142 & 8 & 0 & 3,53 & 0,989 & 20,1 & 1,8 \\
\hline 2018 & $\begin{array}{c}\text { WINERY } \\
44\end{array}$ & W44.7 & PGI Serres & & 2018 & ROSE & $\begin{array}{c}\text { Semi-dry } \\
\text { wine }\end{array}$ & 15,22 & 14,63 & 3,5 & 7,3 & 126 & 29 & 136 & 3,97 & 0,991 & 31 & 9,9 \\
\hline 2018 & $\begin{array}{c}\text { WINERY } \\
44\end{array}$ & W44.8 & PGI Serres & & 2017 & WHITE & Dry wine & 14,54 & 14,41 & 3,5 & 5,6 & 115 & 17 & 2 & 3,94 & 0,988 & 21,6 & 2,2 \\
\hline 2018 & $\begin{array}{c}\text { WINERY } \\
44\end{array}$ & W44.9 & PGI Serres & & 2017 & WHITE & Dry wine & 13,59 & 13,47 & 3,5 & 4,8 & 118 & 26 & 7 & 3,64 & 0,988 & 18,5 & 2,1 \\
\hline 2018 & $\begin{array}{c}\text { WINERY } \\
34\end{array}$ & W34.8 & PGI Serres & & 2017 & ROSE & $\begin{array}{l}\text { Semi-dry } \\
\text { wine }\end{array}$ & 13,03 & 12,66 & 5,4 & 4,4 & 172 & 60 & 145 & 3,37 & 0,992 & 27,4 & 6,3 \\
\hline 2018 & $\begin{array}{c}\text { WINERY } \\
34\end{array}$ & W34.6 & PGI Serres & & 2017 & WHITE & Dry wine & 12,91 & 12,78 & 5,1 & 7,8 & 127 & 44 & 3 & 3,76 & 0,992 & 27,6 & 2,2 \\
\hline 2018 & $\begin{array}{c}\text { WINERY } \\
34\end{array}$ & W34.9 & PGI Serres & & 2017 & WHITE & Dry wine & 13,4 & 13 & 5,3 & 3 & 134 & 38 & 10 & 3,23 & 0,989 & 21,1 & 2,3 \\
\hline 2018 & $\begin{array}{c}\text { WINERY } \\
50\end{array}$ & W50.8 & PGI Serres & & 2017 & ROSE & Dry wine & 12,13 & 11,96 & 4,9 & 4,8 & 125 & 17 & 0 & 3,56 & 0,992 & 23,7 & 2,9 \\
\hline 2018 & $\begin{array}{c}\text { WINERY } \\
50\end{array}$ & W50.3 & PGI Serres & & 2017 & WHITE & Dry wine & 12,24 & 12,15 & 4,7 & 4,6 & 90 & 12 & 1 & 3,35 & 0,989 & 18,5 & 1,5 \\
\hline 2018 & $\begin{array}{c}\text { WINERY } \\
55\end{array}$ & W55.1 & & & 2017 & WHITE & Dry wine & 12,54 & 12,43 & 5,6 & 4,5 & 97 & 17 & 2 & 3,26 & 0,99 & 20,6 & 1,8 \\
\hline
\end{tabular}




\begin{tabular}{|c|c|c|c|c|c|c|c|c|c|c|c|c|c|c|c|c|c|c|}
\hline 2018 & \begin{tabular}{|c|} 
WINERY \\
46
\end{tabular} & W46.5 & PGI Serres & & 2017 & WHITE & Dry wine & 13,06 & 12,91 & 4,2 & 3,2 & 175 & 84 & 3 & 3,45 & 0,988 & 18,3 & 2,5 \\
\hline 2018 & $\begin{array}{c}\text { WINERY } \\
31\end{array}$ & W31.1 & & Wine tanks & 2017 & RED & Dry wine & 13,84 & 13,67 & 4,2 & 15,6 & 81 & 20 & 9 & 3,95 & 0,993 & 31,5 & 2,8 \\
\hline 2018 & $\begin{array}{c}\text { WINERY } \\
46\end{array}$ & W44.11 & PGI Serres & & 2015 & RED & Dry wine & 13,75 & 13,58 & 5,2 & 7 & 133 & 16 & 2 & 3,59 & 0,992 & 30,5 & 2,9 \\
\hline 2018 & \begin{tabular}{|c|} 
WINERY \\
2
\end{tabular} & W2.4 & PGI Serres & & 2016 & RED & Dry wine & 14,05 & 13,79 & 5,2 & 7,9 & 101 & 15 & 3 & 3,57 & 0,993 & 31,8 & 4,3 \\
\hline 2018 & $\begin{array}{c}\text { WINERY } \\
2\end{array}$ & W2.7 & PGI Serres & & 2016 & RED & $\begin{array}{c}\text { Semi-sweet } \\
\text { wine }\end{array}$ & 13,78 & 12,53 & 6 & 8,4 & 148 & 25 & 166 & 3,49 & 1,002 & 53 & 21 \\
\hline 2018 & $\begin{array}{c}\text { WINERY } \\
61\end{array}$ & W61.3 & PGI Serres & & 2014 & RED & Dry wine & 14,22 & 14,08 & 5,7 & 6,9 & 104 & 27 & 11 & 3,47 & 0,92 & 31,8 & 2,4 \\
\hline 2018 & $\begin{array}{c}\text { WINERY } \\
2\end{array}$ & W2.2 & PGI Serres & & 2016 & WHITE & Dry wine & 11,56 & 11,45 & 5,9 & 3,2 & 77 & 31 & 0,2 & 3,1 & 0,991 & 21,1 & 1,9 \\
\hline 2018 & $\begin{array}{c}\text { WINERY } \\
61\end{array}$ & W61.4 & PGI Serres & & 2016 & WHITE & Dry wine & 12,77 & 12,67 & 5,2 & 4 & 188 & 29 & 3 & 3,25 & 0,99 & 22,7 & 1,6 \\
\hline 2018 & $\begin{array}{c}\text { WINERY } \\
49\end{array}$ & W49.6 & $\begin{array}{c}\text { Macedonia } \\
\text { - LW }\end{array}$ & & 2016 & WHITE & Dry wine & 13,69 & 13,38 & 5,6 & 6,5 & 155 & 27 & 1 & 3,4 & 0,991 & 25,3 & 5,2 \\
\hline 2018 & $\begin{array}{c}\text { WINERY } \\
49\end{array}$ & W49.8 & PGI Serres & & 2016 & WHITE & Dry wine & 12,51 & 12,39 & 5,2 & 10 & 164 & 27 & 4 & 3,48 & 0,991 & 22,7 & 2,1 \\
\hline 2018 & $\begin{array}{c}\text { WINERY } \\
21\end{array}$ & W21.8 & PGI Serres & & 2016 & WHITE & Dry wine & 13,54 & 13,4 & 5,1 & 5,5 & 114 & 26 & 7 & 3,47 & 0,989 & 21,6 & 2,3 \\
\hline 2018 & $\begin{array}{c}\text { WINERY } \\
26\end{array}$ & W26.8 & $\begin{array}{l}\text { Varietal } \\
\text { wine }\end{array}$ & & 2016 & WHITE & Dry wine & 13,73 & 13,59 & 5,6 & 5,8 & 96 & 14 & 1 & 3,19 & 0,989 & 22,2 & 2,4 \\
\hline 2018 & $\begin{array}{c}\text { WINERY } \\
44\end{array}$ & W44.10 & PGI Serres & & 2016 & WHITE & Dry wine & 12,85 & 12,74 & 3,6 & 3,8 & 91 & 18 & 2 & 3,47 & 0,988 & 17,5 & 1,9 \\
\hline 2018 & $\begin{array}{c}\text { WINERY } \\
49\end{array}$ & W49.7 & PGI Serres & & 2016 & RED & Dry wine & 15,1 & 14,6 & 4,8 & 9,6 & 108 & 24 & 2 & 3,73 & 0,993 & 36,2 & 8,4 \\
\hline 2018 & \begin{tabular}{|c|} 
WINERY \\
21
\end{tabular} & W21.7 & PGI Serres & & 2015 & RED & Dry wine & 14,22 & 14 & 5,5 & 9,2 & 93 & 11 & 4 & 3,48 & 0,992 & 30 & 3,7 \\
\hline 2018 & $\begin{array}{c}\text { WINERY } \\
21\end{array}$ & W21.3 & PGI Serres & & 2015 & RED & Dry wine & 14,6 & 14,38 & 5 & 8,2 & 132 & 28 & 5 & 3,54 & 0,991 & 29,7 & 3,7 \\
\hline 2018 & $\begin{array}{c}\text { WINERY } \\
44\end{array}$ & W44.6 & PGI Serres & & 2013 & RED & Dry wine & 15,08 & 14,86 & 4,3 & 10 & 67 & 19 & 1 & 3,8 & 0,99 & 28,1 & 3,7 \\
\hline 2018 & $\begin{array}{c}\text { WINERY } \\
27\end{array}$ & W27.11 & $\begin{array}{l}\text { Varietal } \\
\text { wine }\end{array}$ & & 2016 & RED & Dry wine & 12,92 & 12,78 & 5,4 & 6,3 & 101 & 7 & 0 & 3,65 & 0,992 & 27,1 & 2,4 \\
\hline 2018 & $\begin{array}{c}\text { WINERY } \\
22\end{array}$ & W22.2 & & & 2016 & RED & Dry wine & 12,9 & 12,76 & 5,6 & 6,2 & 62 & 7 & 0 & 3,6 & 0,992 & 26,8 & 2,3 \\
\hline 2019 & $\begin{array}{c}\text { WINERY } \\
32\end{array}$ & W32.5 & PGI Serres & & 2018 & ROSE & $\begin{array}{c}\text { Semi-sweet } \\
\text { wine }\end{array}$ & 14,44 & 12,02 & 4,18 & 7,7 & 125 & 12 & 151 & 3,64 & 1,007 & 63,9 & 40,7 \\
\hline 2019 & $\begin{array}{c}\text { WINERY } \\
32\end{array}$ & W32.3 & PGI Serres & & 2018 & WHITE & Dry wine & 12,8 & 12,55 & 4,64 & 4,4 & 127 & 7 & 11 & 3,29 & 0,989 & 20,9 & 4,2 \\
\hline 2019 & $\begin{array}{c}\text { WINERY } \\
46\end{array}$ & W46.8 & PGI Serres & & 2015 & RED & Dry wine & 13,53 & 13,38 & 4,91 & 7,2 & 50 & 20 & 4 & 3,64 & 0,993 & 30 & 2,6 \\
\hline 2019 & $\begin{array}{c}\text { WINERY } \\
46\end{array}$ & W44.12 & PGI Serres & & 2018 & ROSE & Dry wine & 13,2 & 13,02 & 5,08 & 3,6 & 111 & 15 & 5 & 3,38 & 0,99 & 22,7 & 3,1 \\
\hline 2019 & $\begin{array}{c}\text { WINERY } \\
46\end{array}$ & W44.10 & PGI Serres & & 2018 & WHITE & Dry wine & 12,65 & 12,52 & 4,63 & 3,9 & 132 & 13 & 2 & 3,54 & 0,99 & 20,6 & 2 \\
\hline 2019 & $\begin{array}{c}\text { WINERY } \\
53\end{array}$ & W53.1 & $\begin{array}{l}\text { Varietal } \\
\text { wine }\end{array}$ & & 2018 & RED & Dry wine & 13,33 & 13,2 & 4,46 & 9 & 96 & 46 & 1 & 3,83 & 0,993 & 30 & 2,2 \\
\hline 2019 & $\begin{array}{c}\text { WINERY } \\
53 \\
\end{array}$ & W53.2 & PGI Serres & & 2018 & WHITE & Dry wine & 12,89 & 12,81 & 4,73 & 3,5 & 122 & 31 & 6 & 3,55 & 0,989 & 20,6 & 1,4 \\
\hline
\end{tabular}




\begin{tabular}{|c|c|c|c|c|c|c|c|c|c|c|c|c|c|c|c|c|c|c|}
\hline 2019 & \begin{tabular}{|c} 
WINERY \\
53
\end{tabular} & W53.3 & PGI Serres & & 2018 & ROSE & $\begin{array}{c}\text { Semi-sweet } \\
\text { wine }\end{array}$ & 13,35 & 12,23 & 4,61 & 6,5 & 106 & 17 & 183 & 3,58 & 1,0148 & 84,7 & 18,9 \\
\hline 2019 & $\begin{array}{c}\text { WINERY } \\
48\end{array}$ & W48.4 & PGI Serres & & 2017 & RED & Dry wine & 14,25 & 14,14 & 4 & 6,6 & 60 & 14 & 1 & 3,91 & 0,991 & 28,4 & 1,9 \\
\hline 2019 & $\begin{array}{c}\text { WINERY } \\
48\end{array}$ & W48.3 & PGI Serres & & 2018 & WHITE & Dry wine & 12,86 & 12,78 & 5,51 & 4,4 & 96 & 19 & 0 & 3,33 & 0,988 & 18 & 1,4 \\
\hline 2019 & $\begin{array}{c}\text { WINERY } \\
38\end{array}$ & W38.1 & PGI Serres & & 2018 & WHITE & Dry wine & 12,3 & 12,21 & 5,55 & 2,2 & 116 & 26 & 1 & 3,39 & 0,989 & 20,1 & 1,5 \\
\hline 2019 & $\begin{array}{c}\text { WINERY } \\
51\end{array}$ & W51.1 & PGI Serres & & 2017 & WHITE & Dry wine & 11,71 & 11,6 & 5,23 & 7,3 & 54 & 12 & 6 & 3,33 & 0,99 & 19,8 & 1,9 \\
\hline 2019 & $\begin{array}{c}\text { WINERY } \\
30\end{array}$ & W30.4 & PGI Serres & & 2018 & ROSE & Dry wine & 13,06 & 12,92 & 5,3 & 9,5 & 109 & 21 & 6 & 3,71 & 0,991 & 26,6 & 2,3 \\
\hline 2019 & $\begin{array}{c}\text { WINERY } \\
51\end{array}$ & W51.2 & PGI Serres & Wine tanks & 2018 & RED & Dry wine & 14,57 & 14,36 & 4,41 & 11,7 & 64 & 13 & 8 & 4,18 & 0,996 & 40,9 & 3,5 \\
\hline 2019 & $\begin{array}{c}\text { WINERY } \\
51\end{array}$ & W51.2 & PGI Serres & & 2017 & RED & Dry wine & 13,15 & 13 & 4,91 & 7,9 & 76 & 14 & 8 & 3,75 & 0,994 & 32,8 & 2,5 \\
\hline 2019 & $\begin{array}{c}\text { WINERY } \\
30\end{array}$ & W30.2 & PGI Serres & & 2018 & RED & Dry wine & 14,15 & 14 & 5,12 & 5,8 & 61 & 14 & 2 & 3,73 & 0,994 & 35,9 & 2,6 \\
\hline 2019 & $\begin{array}{c}\text { WINERY } \\
30\end{array}$ & W30.1 & PGI Serres & & 2018 & WHITE & Dry wine & 12,75 & 12,64 & 5,63 & 7,7 & 95 & 14 & 0 & 3,66 & 0,99 & 24 & 1,9 \\
\hline 2019 & $\begin{array}{c}\text { WINERY } \\
40\end{array}$ & W40.2 & PGI Serres & Wine tanks & 2018 & WHITE & Dry wine & 11,76 & 11,68 & 4,61 & 4 & 168 & 5 & 1 & 3,68 & 0,991 & 20,9 & 1,3 \\
\hline 2019 & $\begin{array}{c}\text { WINERY } \\
40\end{array}$ & W40.3 & PGI Serres & Wine tanks & 2015 & RED & Dry wine & 13,25 & 13,1 & 5,06 & 10,7 & 46 & 7 & 2 & 3,59 & 0,993 & 29,7 & 2,6 \\
\hline 2019 & $\begin{array}{c}\text { WINERY } \\
40\end{array}$ & W40.4 & PGI Serres & Wine tanks & 2015 & RED & Dry wine & 13,19 & 13,04 & 4,71 & 10,3 & 56 & 7 & 3 & 3,55 & 0,992 & 27,1 & 2,5 \\
\hline 2019 & $\begin{array}{c}\text { WINERY } \\
26\end{array}$ & W26.6 & $\begin{array}{c}\text { Organic } \\
\text { Varietal } \\
\text { wine }\end{array}$ & & 2017 & RED & Dry wine & 15,45 & 15,21 & 5,92 & 7,4 & 94 & 15 & 15 & 3,45 & 0,991 & 32,6 & 4 \\
\hline
\end{tabular}

Table B6. Samples from Regional District (Prefecture) of Xanthi

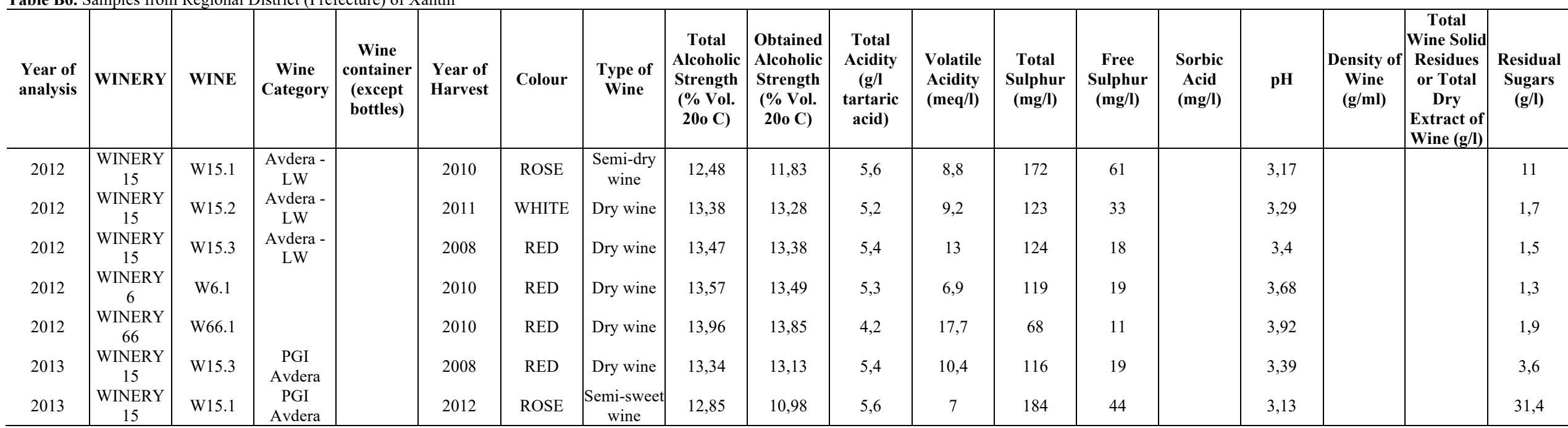




\begin{tabular}{|c|c|c|c|c|c|c|c|c|c|c|c|c|c|c|c|c|c|}
\hline 2013 & \begin{tabular}{|c|} 
WINERY \\
6
\end{tabular} & W6.2 & $\begin{array}{c}\text { PGI } \\
\text { Avdera }\end{array}$ & 2012 & RED & Dry wine & 14,04 & 13,74 & 4,7 & 11,5 & 108 & 45 & & 3,67 & & & 5 \\
\hline 2013 & $\begin{array}{c}\text { WINERY } \\
54\end{array}$ & W54.1 & & 2012 & WHITE & Dry wine & 11,12 & 11,02 & 5,3 & 18,7 & 105 & 6 & & 3,64 & & & 1,7 \\
\hline 2013 & $\begin{array}{c}\text { WINERY } \\
54\end{array}$ & W54.2 & & 2012 & RED & $\begin{array}{c}\text { Semi-sweet } \\
\text { wine }\end{array}$ & 12,19 & 10,9 & 4,6 & 11,8 & 76 & 24 & & 3,79 & & & 21,7 \\
\hline 2013 & $\begin{array}{c}\text { WINERY } \\
54\end{array}$ & W54.3 & & 2012 & RED & Dry wine & 11,93 & 11,81 & 5,1 & 16 & 88 & 24 & & 3,74 & & & 2 \\
\hline 2014 & \begin{tabular}{|c|} 
WINERY \\
15
\end{tabular} & W15.2 & $\begin{array}{c}\text { PGI } \\
\text { Avdera }\end{array}$ & 2013 & WHITE & Dry wine & 13,35 & 13,23 & 5,7 & 8,8 & 149 & 61 & & 3,03 & 0,989 & 20,3 & 2,1 \\
\hline 2014 & $\begin{array}{c}\text { WINERY } \\
6\end{array}$ & W6.2 & $\begin{array}{c}\text { PGI } \\
\text { Avdera }\end{array}$ & 2012 & RED & Dry wine & 13,24 & 13,1 & 4,6 & 8,6 & 181 & 36 & & 3,67 & 0,992 & 27,9 & 2,3 \\
\hline 2014 & \begin{tabular}{|c|} 
WINERY \\
15
\end{tabular} & W15.4 & $\begin{array}{l}\text { Varietal } \\
\text { wine }\end{array}$ & 2013 & WHITE & Dry wine & 13,8 & 13,63 & 5,1 & 6,6 & 149 & 49 & & 3,17 & 0,99 & 21,6 & 2,9 \\
\hline 2016 & $\begin{array}{c}\text { WINERY } \\
6\end{array}$ & W6.2 & $\begin{array}{c}\text { PGI } \\
\text { Avdera }\end{array}$ & 2013 & RED & Dry wine & 13,57 & 13,37 & 4,3 & 8,7 & 127 & 11 & & 3,65 & 0,992 & 27,9 & 3,4 \\
\hline 2016 & $\begin{array}{c}\text { WINERY } \\
6\end{array}$ & W6.2 & $\begin{array}{c}\text { PGI } \\
\text { Avdera }\end{array}$ & 2013 & RED & Dry wine & 13,51 & 13,35 & 4,4 & 9,3 & 176 & 24 & & 3,66 & 0,991 & 27,4 & 2,7 \\
\hline 2016 & \begin{tabular}{|c|} 
WINERY \\
15
\end{tabular} & W15.7 & $\begin{array}{c}\text { PGI } \\
\text { Avdera }\end{array}$ & 2012 & RED & Dry wine & 13,73 & 13,53 & 5,9 & 10,9 & 127 & 23 & & 3,42 & 0,995 & 36,5 & 3,3 \\
\hline 2016 & $\begin{array}{c}\text { WINERY } \\
15\end{array}$ & W15.6 & $\begin{array}{l}\text { Varietal } \\
\text { wine }\end{array}$ & 2015 & ROSE & $\begin{array}{c}\text { Semi-sweet } \\
\text { wine }\end{array}$ & 12,97 & 11,48 & 4,9 & 8,6 & 154 & 37 & & 3,22 & 1,004 & 53,5 & 25,1 \\
\hline 2016 & $\begin{array}{c}\text { WINERY } \\
15\end{array}$ & W15.4 & $\begin{array}{l}\text { Varietal } \\
\text { wine }\end{array}$ & 2015 & WHITE & Dry wine & 12,75 & 12,61 & 5,4 & 8,4 & 118 & 28 & & 3,25 & 0,992 & 18,5 & 2,4 \\
\hline 2017 & $\begin{array}{c}\text { WINERY } \\
26\end{array}$ & W26.5 & PGI Drama & 2015 & RED & Dry wine & 14,6 & 14,42 & 5,2 & 10,7 & 99 & 22 & 2 & 3,53 & 0,992 & 31,3 & 3,1 \\
\hline 2018 & $\begin{array}{c}\text { WINERY } \\
15\end{array}$ & W15.2 & $\begin{array}{c}\text { PGI } \\
\text { Avdera }\end{array}$ & 2016 & WHITE & Dry wine & 11,81 & 11,58 & 6,4 & 4,9 & 120 & 20 & 62 & 3,25 & 0,993 & 25 & 4,1 \\
\hline 2018 & $\begin{array}{c}\text { WINERY } \\
71\end{array}$ & W71.1 & & 2015 & RED & Dry wine & 12,52 & 12,38 & 4,3 & 5,5 & 77 & 13 & 0 & 3,81 & 0,993 & 29,5 & 2,3 \\
\hline 2019 & $\begin{array}{c}\text { WINERY } \\
6\end{array}$ & W6.3 & $\begin{array}{c}\text { PGI } \\
\text { Avdera }\end{array}$ & 2018 & ROSE & $\begin{array}{c}\text { Semi-dry } \\
\text { wine }\end{array}$ & 12,66 & 11,91 & 5,96 & 5,6 & 196 & 50 & 135 & 3,56 & 0,996 & 34,6 & 12,6 \\
\hline 2019 & $\begin{array}{c}\text { WINERY } \\
15\end{array}$ & W15.7 & $\begin{array}{l}\text { Varietal } \\
\text { wine }\end{array}$ & 2018 & RED & Dry wine & 12,93 & 12,75 & 5,13 & 7,4 & 75 & 18 & 5 & 3,53 & 0,993 & 29,4 & 3,1 \\
\hline 2019 & $\begin{array}{c}\text { WINERY } \\
15\end{array}$ & W15.5 & $\begin{array}{c}\text { PGI } \\
\text { Avdera }\end{array}$ & 2018 & WHITE & Dry wine & 13,58 & 13,43 & 5,6 & 6,4 & 114 & 22 & 7 & 3,06 & 0,988 & 20,3 & 2,5 \\
\hline
\end{tabular}

Table B7. Samples taken from food and beverage stores

\begin{tabular}{|c|c|c|c|c|c|c|c|c|c|c|c|c|c|c|c|c|c|c|c|}
\hline $\begin{array}{l}\text { Year of } \\
\text { analysis }\end{array}$ & $\begin{array}{c}\text { Regional } \\
\text { District, } \\
\text { where the } \\
\text { sampling } \\
\text { took place }\end{array}$ & WINERY & WINE & $\begin{array}{c}\text { Wine } \\
\text { Category }\end{array}$ & $\begin{array}{c}\text { Wine } \\
\text { container } \\
\text { (except } \\
\text { bottles) }\end{array}$ & $\begin{array}{l}\text { Year of } \\
\text { Harvest }\end{array}$ & Colour & $\begin{array}{c}\text { Type of } \\
\text { Wine }\end{array}$ & $\begin{array}{c}\text { Total } \\
\text { Alcoholic } \\
\text { Strength } \\
\text { (\% Vol. } \\
\text { 20o C) }\end{array}$ & $\begin{array}{c}\text { Obtained } \\
\text { Alcoholic } \\
\text { Strength } \\
\text { (\% Vol. } \\
\text { 20o C) }\end{array}$ & $\begin{array}{c}\text { Total } \\
\text { Acidity } \\
\text { (g/l } \\
\text { tartaric } \\
\text { acid) }\end{array}$ & $\begin{array}{l}\text { Volatile } \\
\text { Acidity } \\
\text { (meq/l) }\end{array}$ & $\begin{array}{c}\text { Total } \\
\text { Sulphur } \\
(\mathrm{mg} / \mathrm{l})\end{array}$ & $\begin{array}{c}\text { Free } \\
\text { Sulphur } \\
(\mathrm{mg} / \mathrm{l})\end{array}$ & $\begin{array}{c}\text { Sorbic } \\
\text { Acid } \\
(\mathrm{mg} / \mathrm{l})\end{array}$ & pH & $\begin{array}{c}\text { Density of } \\
\text { Wine } \\
(\mathrm{g} / \mathrm{ml})\end{array}$ & \begin{tabular}{|c|} 
Total \\
Wine \\
Solid \\
Residues \\
or Total \\
Dry \\
Extract of \\
Wine (g/l)
\end{tabular} & $\begin{array}{c}\text { Residual } \\
\text { Sugars } \\
(\mathrm{g} / \mathrm{l})\end{array}$ \\
\hline 2018 & DRAMA & SM6 & SM6.1 & \begin{tabular}{|c|} 
PGI Sterea \\
Hellas
\end{tabular} & & 2016 & WHITE & Dry wine & 12,56 & 12,39 & 4,85 & 5,1 & 122 & 40 & 0 & 3,47 & 0,991 & 24,2 & 2,8 \\
\hline 2018 & DRAMA & SM8 & SM8.1 & $\mid \begin{array}{c}\text { PGI } \\
\text { Peloponnessos }\end{array}$ & & 2017 & WHITE & Dry wine & 11,55 & 11,49 & 5,68 & 3,5 & 78 & 14 & 0 & 3,33 & 0,99 & 19 & 1 \\
\hline
\end{tabular}




\begin{tabular}{|c|c|c|c|c|c|c|c|c|c|c|c|c|c|c|c|c|c|c|}
\hline 2018 & \begin{tabular}{|l|} 
LESVOS \\
\end{tabular} & SM4 & SM4.1 & PDO Lemnos & 2017 & WHITE & Dry wine & 12,34 & 12,23 & 4,6 & 4,7 & 132 & 25 & 0 & 3,37 & 0,99 & 21,4 & 1,9 \\
\hline 2018 & XANTHI & SM7 & SM7.1 & PDO Nemea & 2016 & RED & Dry wine & 12,38 & 12,24 & 4,6 & 5,8 & 122 & 21 & 5 & 3,54 & 0,992 & 25,8 & 2,4 \\
\hline 2019 & DRAMA & SM1 & SM1.1 & Varietal wine & 2018 & WHITE & Dry wine & 11,96 & 11,87 & 5 & 3,3 & 93 & 18 & 1 & 3,34 & 0,99 & 19,8 & 1,5 \\
\hline 2019 & DRAMA & SM8 & SM8.2 & \begin{tabular}{|c|} 
PGI \\
Peloponnessos
\end{tabular} & 2018 & RED & Dry wine & 12,58 & 12,39 & 4,88 & 8,2 & 66 & 12 & 16 & 3,6 & 0,992 & 25,8 & 3,2 \\
\hline 2019 & SERRES & SM2 & SM2.1 & \begin{tabular}{c|} 
PGI \\
Peloponnessos
\end{tabular} & 2018 & RED & Dry wine & 13,02 & 12,88 & 4,82 & 8,8 & 98 & 14 & 0 & 3,68 & 0,992 & 27,1 & 2,4 \\
\hline 2019 & SERRES & SM3 & SM3.1 & \begin{tabular}{c|} 
PGI \\
Peloponnessos
\end{tabular} & 2018 & RED & Dry wine & 13,5 & 13,19 & 4,94 & 8,5 & 83 & 28 & 1 & 3,71 & 0,994 & 32,6 & 5,2 \\
\hline 2019 & SERRES & SM5 & SM5.1 & \begin{tabular}{c|} 
PGI \\
Peloponnessos
\end{tabular} & 2018 & WHITE & Dry wine & 11,34 & 11,27 & 4,92 & 4,1 & 131 & 33 & 0 & 3,59 & 0,991 & 20,6 & 1,2 \\
\hline
\end{tabular}

